UNIVERSIDADE DE SÃO PAULO

FACULDADE DE FILOSOFIA, LETRAS E CIÊNCIAS HUMANAS

DEPARTAMENTO DE GEOGRAFIA

NELIANE DE SOUSA ALVES

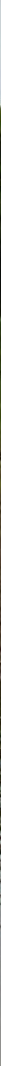

São Paulo 


\section{UNIVERSIDADE DE SÃO PAULO \\ FACULDADE DE FILOSOFIA, LETRAS E CIÊNCIAS HUMANAS \\ DEPARTAMENTO DE GEOGRAFIA}

NELIANE DE SOUSA ALVES

Mapeamento Hidromorfodinâmico do Complexo Fluvial de Anavilhanas.

Contribuição aos estudos de Geomorfologia Fluvial de rios Amazônicos

Versão Corrigida

São Paulo

2013 
NELIANE DE SOUSA ALVES

\title{
Mapeamento Hidromorfodinâmico do Complexo Fluvial de Anavilhanas. Contribuição aos estudos de Geomorfologia Fluvial de rios Amazônicos
}

\author{
Tese apresentada ao Programa de Pós-graduação \\ em Geografia Física, do Departamento de \\ Geografia da Faculdade de Filosofia, Letras e \\ Ciências Humanas da Universidade de São \\ Paulo, como parte dos requisitos para obtenção \\ do título de Doutora em Geografia. \\ Orientadora: Prof ${ }^{a}$. Dr ${ }^{a}$. Cleide Rodrigues
}

Versão Corrigida

De acordo:

Profa. Dra. Cleide Rodrigues

São Paulo

2013 


\section{Mapeamento Hidromorfodinâmico do Complexo Fluvial de Anavilhanas. Contribuição aos estudos de Geomorfologia Fluvial de rios Amazônicos}

Tese apresentada ao Programa de Pós-graduação em Geografia Física, do Departamento de Geografia da Faculdade de Filosofia, Letras e Ciências Humanas da Universidade de São Paulo, como parte dos requisitos para obtenção do título de Doutora em Geografia.

Nome - Professora orientadora Prof $^{\mathrm{a}}$. Dr ${ }^{\mathrm{a}}$. Cleide Rodrigues

Nome - Professor convidado

Prof. Dr. Archimedes Perez Filho

Nome - Professor convidado

Prof. Dr. Edvard Elias Souza Filho

Nome - Professor convidado

Prof. Dr. Jurandyr Luciano Sanches Ross

Nome - Professora convidada

Prof $^{a}$. Dr ${ }^{a}$. Rosely Pacheco Dias Ferreira

São Paulo, de de 2013 
Para João Guilherme, meu filho e companheiro de muitas lutas, amigo de fé que me ensinou que com amor, paciência e dedicação tudo é possível, basta acreditar. 


\section{AGRADECIMENTOS}

Agradeço de uma maneira muito especial a minha orientadora, Dra ${ }^{\mathrm{a}}$. Cleide Rodrigues, que superando todas as adversidades foi além de sua função como orientadora, se tornando amiga, companheira e conselheira nos momentos de dificuldades e de saudades de casa. Agradeço pelo seu apoio, orientação, dedicação, ensinamentos e por acreditar em mim e neste trabalho.

À Prof ${ }^{a}$. Dra . Rosely Pacheco Dias Ferreira e ao Prof. Dr. Edvard Elias Souza Filho pelas contribuições e críticas quando da qualificação deste doutorado.

À Fundação de Amparo à Pesquisa do Estado do Amazonas - FAPEAM pela concessão da bolsa de Doutorado, programa RH - Interinstitucional.

À Companhia de Pesquisa e Recursos Minerais - CPRM, na pessoa do Superintendente Regional o Dr. Marco Antônio Oliveira pelo empréstimo das fotografias aéreas e mapas, e ao Sr. Valdemilton F. Gusmão pela atenção dispensada.

Ao Laboratório de Solos - LATOSSOLO da Universidade Federal do Amazonas, na pessoa do Prof. Dr. Antônio Fábio Sabbá Guimarães Viera, pelo uso do laboratório para a realização das análises granulométricas, e ao técnico do laboratório Francisco Weliton Rocha Silva pelo apoio e discussões.

À Prof ${ }^{a}$. Dr ${ }^{\mathrm{a}}$. Eglê Betânia Portela Wanzeler, diretora da Escola Normal Superior, pelo incentivo e apoio a conclusão deste estudo.

À Universidade do Estado do Amazonas, em especial a Coordenação do Doutorado Interinstitucional - DINTER, na pessoa da professora coordenadora do programa a Dra. Maria de Nazaré Ribeiro pelo apoio dispensado.

À Brenda da Silva Carvalho e Edailza Batista da Gama, alunas do curso de Geografia da UEA e bolsistas de Iniciação Científica, pelo auxílio e contribuição nas etapas de campo e análises laboratoriais. 
Aos mestres e colegas do curso de Licenciatura em Geografia da Universidade do Estado do Amazonas: Marcela Pereira Mafra, Isaque dos Santos Sousa, José Roselito Carmelo, Alcirene Maria Cursino e Ana Paulina Aguiar, pelo suporte durante os períodos em que tive que me ausentar da sala de aula.

Aos amigos e professores Deivison Carvalho Molinari, Anne Dirane, Otávio Rios e Israel Klinger pelas contribuições nos trabalhos de campo e elaboração de mapas.

Aos companheiros doutorandos e colegas de casa em São Paulo: Isaque Sousa, Geraldo Valle, Danielle Costa, Simone Carvalho, Dayson Jardim e sua esposa Naiara Almeida, e Edilene Maduro, pela amizade e companheirismo nas horas de dificuldades e saudades de casa.

À Helena Franco Parrón, amiga e companheira de todas as horas que reencontrei em São Paulo e cuja amizade é incomensurável.

Aos amigos e compadres Juciane Calvalheiro e Maurício Matos, pela amizade, carinho e força sempre dedicados.

Aos novos amigos do Laboratório de Geomorfologia da USP: A Dra. Marisa de Souto Matos Fierz e Paulo Ricardo de Castro, pela atenção dedicada. Ao Paulo incluo agradecimentos pela confecção dos mapas.

Agradeço, de maneira especial, ao meu filho João Guilherme que cuidou de tudo enquanto me dedicava aos estudos, e sempre me incentivou nos momentos de desânimo e dificuldades. Obrigada meu filho, sua ajuda e seu apoio foram imprescindíveis.

A Deus, fonte de todo amor e sentido de minha existência. A fé, que tudo supera, foi minha companheira durante estes quatro anos. Obrigada Senhor, por me fortalecer a cada dia e manter acessa em meu coração a chama do amor e da esperança de que tudo é possível para aqueles que acreditam. 


\section{RESUMO}

Este estudo dedicou-se à identificação de unidades morfológicas e suas respectivas tendências espaciais de processos hidromorfodinâmicos no baixo curso do rio Negro, na área do Complexo de Anavilhanas, produzindo-se a cartografia na escala 1:100.000. Esta cartografia apoiou-se na articulação de dados primários e secundários morfológico-morfométricos, hidrológicos, sedimentológicos e de cobertura vegetal. Dentre os primeiros, foram utilizados parâmetros como largura, declividades, extensão, geometria e distribuição das morfologias. Em relação aos parâmetros hidrológicos, foram acessados e tratados dados como: vazões diárias anuais, regime fluvial, velocidade de fluxo, amplitude anual de cotas fluviais, dentre outros. Para os sedimentológicos, foram observados 04 perfis e coletadas 54 amostras em diversos pontos representativos das unidades morfológicas identificadas, utilizando-se de parâmetros como: textura, estrutura e alguns elementos estratigráficos e de arquitetura deposicional. As informações de cada um destes ramos do conhecimento foram articuladas numa primeira versão de mapeamento. A partir destas correlações espaciais, partiu-se para proposição das tendências espaciais de balanços e tipos de processos atuantes em cada uma das unidades. As unidades e seus processos predominantes foram assim sistematizados: Sistema Canal, Planície de Inundação e Terra Firme. O primeiro inclui os subsistemas ria padrão anastomosado e ria padrão dendrítico, as barras fluviais e margens. O sistema Planície de Inundação inclui as ilhas, diques e lagos. Estes compartimentos geomorfológicos apresentam comportamentos sazonais distintos em períodos de estiagem, na subida das águas e nas cheias, todos comandados pelo efeito de barramento hidráulico causado pela variação anual dos níveis d'água do rio Solimões, determinando para o rio Negro uma amplitude anual das cotas de 11 metros. A dinâmica fluvial no sistema de canal é caracterizada pela alta variabilidade anual das cotas, altas vazões médias anuais, altos valores de transporte de carga orgânica anuais, baixos valores de velocidade e alta taxa de transporte de carga de fundo. $\mathrm{O}$ sistema planície de inundação caracteriza-se por processos deposicionais de acresção vertical com taxas anuais pouco expressivas nos lagos e diques, e alta estabilidade das formas, favorecida pela coesão do material síltico-argiloso dos diques. A exceção a esta estabilidade são as "terras caídas" (queda de parte das margens e vertentes) e as falésias fluviais na Terra Firme. No conjunto evidenciou-se um balanço erosivo-sedimentar pouco efetivo do ponto de vista das mudanças morfológicas anuais. O estudo permitiu a proposição de uma matriz explicativa para a atual estabilidade morfológica das formas da planície de inundação do Complexo de Anavilhanas, em contraposição à alta magnitude dos processos hidrológicos e de transporte de fundo dos canais principais. Por outro lado, evidenciaram-se também dificuldades para se classificar o complexo em relação às atuais referências de classificação de padrões fluviais, sugerindo a singularidade dos rios amazônicos, ainda pouco estudados na perspectiva geomorfológica.

Palavras-chave: Anavilhanas, Rio Negro, Hidromorfodinâmica, Mapeamento Geomorfológico 


\begin{abstract}
This study was developed to identify morphological units and their spatial trends of hydromorphodinamic processes of lower areas of Rio Negro river, called Anavilhanas Complex, producing mapping at $1: 100,000$ scale. This mapping is supported by the correlation between secondary and field data of morphological, morphometric, hydrological, sedimentological and vegetation cover characteristics. Regarding the morphological and morphometric characteristics, we used parameters such as width, slope angle, length, geometry and spatial distribution. In terms of hydrological parameters, were considered annual daily flow, annual flow regime, flow velocity, annual amplitude of water level, among others. Four soil and sedimentary profiles and 54 sedimentary samples were collected and analyzed at different and representative points of morphological identified units, using parameters such as texture, structure and some elements of stratigraphic and depositional architecture. The data of these scientific fields was integrated in a first version of the map. Based on these spatial correlations were proposed spatial trends of balance and types of hydrodinamics processes that is operating in each of the morphological units of: river channel, floodplain and slopes ("terra firme") systems. In the river channel system were included the subsystems such anastomosed ria system, dendritic ria system, bars and margins. The floodplain system includes islands, levées and lakes. These geomorphological units have distinct seasonal hydrodinamic processes over hydrological year and are controlled by the variability of water levels of the Solimões river that determines an amplitude about 11 meters to Negro river. The fluvial dynamics of the channel systems units are characterized by high magnitude of fluvial flows and amplitude of water level, low rates of organic load, low values of flow velocity and high rate of annual bed load transport. The floodplain system are charachterized by low rates of depositional processes of vertical accretion in the lakes and levées, and high form stability, favored by the material cohesion silty-clay of the levées. The exceptions to this stability are the "terras caídas" (falls of part of margins and slopes) and fluvial cliffs in Terra Firme. As demonstrated above, the hole complex can be considered as an ineffective sedimentary environment from the point of view of yearly morphological changes. The study allowed to propose an explanatory matrix for the current stability of the morphological forms of the floodplain Complex Anavilhanas in contrast to the high magnitude of hydrological processes and bed load transport of the main river channels. Moreover, it is also demonstrated some difficulties to classify the complex according to the current references of river channel patterns, suggesting the uniqueness of the Amazon rivers, less studied by the point of view of geomorphology.
\end{abstract}

Keywords: Anavilhanas, Negro River, Hydromorphodinamic, Geomorphological Mapping 


\section{LISTA DE FIGURAS}

Figura 1: Bacia Hidrográfica do Amazonas

Figura 2: Bacia Hidrográfica do Rio Negro

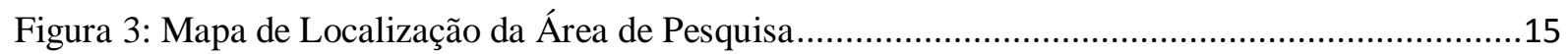

Figura 4: Unidade de Conservação PARNA de Anavilhanas (AM) ................................................18

Figura 5: A: Parque Nacional de Anavilhanas (Fonte: www.icmbio.gov.br); B: Botos tucuxis (Sotalia

fluviatilis); C: Ecossistema Lacustre; D: Ilha fluvial (imagens da autora).....

Figura 6: Contexto geotectônico da Plataforma Sul-Americana e a Bacia do Amazonas ....................20

Figura 7: Coluna Estratigráfica da Bacia do Amazonas..............................................................22

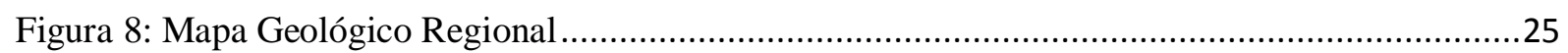

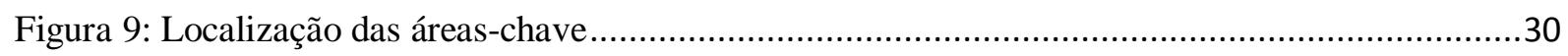

Figura 10: Principais estruturas neotectônicas da região centro-oeste do Amazonas............................31

Figura 11: Principais Lineamentos estruturais do baixo Rio Negro (adaptado de FRANZINELLI e IGREJA, 1990).

Figura 12: Unidades Geomorfológicas

Figura 13: A: Mata de igapó; B: Floresta de Terra Firme; C: Escheweleira tenuifolia (Macacarecuia); D: Florestas inundadas de Macacarecuias (Escheweleira tenuifolia). (imagens da autora).

Figura 14: Planície de inundação de canais anastomosados, CH: Canal, FF: Finos da planície de inundação; LA: Macroformas de acresção lateral; CS: Depósitos de rompimento de diques.

Figura 15: Classificação dos canais fluviais segundo Schumm (1981) 65

Figura 16: Diferenças entre os tipos de rios anabranches com base na potência de fluxo, sedimento, forma e processos.

Figura 17: Rio Anabranches - Tipo 1: rio anastomosado com leito de sedimentos coesos (NANSON E

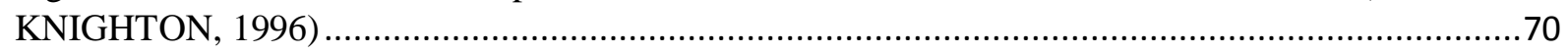

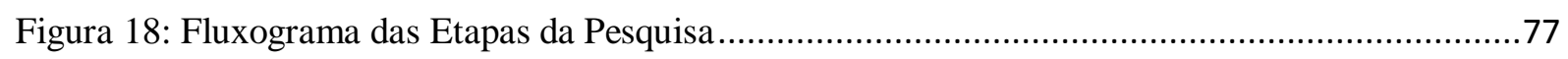

Figura 19: A: Embarcação utilizada nos trabalhos de campo; B: Preparação dos perfis; C: Tradagem; D: Levantamento de dados morfométricos. (imagens da autora, 2011). 
Figura 20: Mapa de Localização dos pontos levantados e amostrados em campo

Figura 21: Diagrama Triangular de Flemming (2000).....

Figura 22: Modelo de elevação digital (SRTM) em (a) e (b) mostrando o antigo paleocanal (indicado pela seta vermelha) entre os rios Padauari e Carabinani, que ligava o rio Negro ao Manacapuru. .......92

Figura 23: Carta de chuvas médias anuais para a Bacia Amazônica no período de 1970-1996. 99

Figura 24: Variabilidade sazonal dos níveis dos rios na Bacia Amazônica 104

Figura 25: Vetores regionais de tendências pluviométricas 108

Figura 26: Precipitação Média Mensal Histórica (1982-2011) para Estação São Felipe - 8067001 ...109

Figura 27: Precipitação Média Mensal Histórica (1982-2011) para Estação Tapuruquara - 65001 ...110

Figura 28: Precipitação Média Mensal Histórica (1982-2011) para Estação Moura - 161002 110

Figura 29: Precipitação Média Mensal Histórica (1982-2011) para Estação Manaus - 82331 111

Figura 30: Estação de Cucuí - Vazão Média Mensal (1982-2011) 113

Figura 31: Estação de São Felipe - Vazão Média Mensal (1982-2011)..... 114

Figura 32: Estação de Curicuriari - Vazão Média Mensal (1982-2011) 114

Figura 33: Estação de Serrinha - Vazão Média Mensal (1982-2011) .115

Figura 34: Estação de Paricatuba - Medidas de Vazão Mensal

Figura 35: Relação Vazão x Velocidade para a estação de Paricatuba 117

Figura 36: Comparação entre as Velocidades Médias Mensais medidas nas estações de Cucuí, Serrinha e Paricatuba. 118

Figura 37: Diagrama de Hjulstrom 119

Figura 38: Estações hidrológicas do Rio Negro 123

Figura 39: Frequência dos eventos segundo amplitudes anuais das cotas medidas no Porto de Manaus no período de 1902-2010 125

Figura 40: Cotagramas das maiores cheias em Manaus - Rio Negro.... 127

Figura 41: Distribuição histórica (\%) de cotas máximas e mínimas do Rio Negro em Manaus (atualizado até 2010). 128

Figura 42: A: Porto de Manaus. Cota: 29,78. Data da foto: 16/05/2012. (Autor: Edaílza B. da Gama); B: Prédio da Alfândega em Manaus. Data da foto: 20/05/2012 (Fonte: internet). 130 
Figura 43: Praia de Novo Airão com porto flutuante ao fundo. A: vazante de 2010: cota do rio Negro em Manaus 30/10/2010: 13,85 m; B: cheia de 2012; cota do rio Negro em Manaus 17/06/2012: 29,61 metros. C e D: Praia de Novo Airão com vista para montante do arquipélago. C: vazante de 2010; D: cheia de 2012; cota do rio Negro em Manaus 17/06/2012: 29,61 metros. Diferença das cotas: 15,76 metros. (imagens da autora)

Figura 44: Promontório da Ilha Grande das Anavilhanas e Praia do Meio. A: Vazante de 2011. Cota do rio Negro em Manaus em 27/11/2011: 17,69 metros; B: Cheia de 2012. Cota do rio Negro em 17/06/2012: 29,61 metros. C: Vazante de 2011; D: Cheia de 2012; E: Praia do Meio, vazante de 2011; F: Praia do Meio; cheia de 2012. Diferença das cotas: 11,92 metros. Direção da tomada das fotos: A e B: NE-SW; C e B: NW-SE e E e F: aproximadamente N-S. (imagens da autora) 132

Figura 45: Entrada do Furo que liga Paraná ao Lago Tamatá. A: Imagem da vazante de 2011: cota do rio Negro em Manaus em 25/10/2011: 17,64 metros; B: Imagem da cheia de 2012: cota do rio Negro em Manaus em 17/06/2012: 29,61 metros; C e D: Mesmo local com vista do furo a partir do Lago Tamatá; C: Imagem da vazante de 2011; D: Imagem da cheia de 2012; E: Lago Tamatá, vazante de 2011; F: Lago Tamatá, cheia de 2012. Diferença das cotas: 11,97 metros. (imagens da autora)...... 133

Figura 46: Praia do Sapato e Paraná do Sapato. A: vazante de 2010: cota do rio Negro em Manaus 30/10/2010: 13,85 m; B: cheia de 2012; cota do rio Negro em Manaus 17/06/2012: 29,61 metros. Diferença das cotas: 15,76 metros. C: Lago do Arraia, vazante de 2011 cota do rio Negro em Manaus em 26/10/2011: 17,67 metros; D: cheia de 2012 cota do rio Negro em Manaus em 17/06/2012: 29,61 metros. Diferença das cotas: 11,94 metros. (imagens da autora).

Figura 47: Ria - Padrão Anastomosado: Canal Principal do Rio Negro 137

Figura 48: Ria - Padrão Anastomosado: Paranás 138

Figura 49: Ria - Padrão Anastomosado: Furos 139

Figura 50: Ria - Padrão Dentrítico: Igarapés 140

Figura 51: Barras Fluviais Centrais e Laterais na área do Complexo de Anavilhanas. 142

Figura 52: Exemplos de morfologias de barras fluviais: A: Barra fluvial lateral localizada na confluência do igarapé com o rio Negro; B: Barras fluviais centrais; C: Barra fluvial lateral jusante do arquipélago; D: Barra fluvial central - Praia do Meio (imagens da autora).

Figura 53: Promontórios das ilhas do Complexo de Anavilhanas 145

Figura 54: Ilhas: Diques Longitudinais 146

Figura 55: Lagos - Zonas Marginais e Centrais ..... 148

Figura 56: Localização e Descrição do Perfil 1 .152

Figura 57: Localização e Descrição do Perfil 2 .154

Figura 58: Localização e Descrição do Perfil 3 .156

Figura 59: Localização e Descrição do Perfil 4. 
Figura 60: Diagrama de barras de distribuição de frequência das frações granulométricas dos diques longitudinais. 160

Figura 61: A: Dique Longitudinal - Lama Levemente Arenosa; B: Dique Longitudinal - Lama Arenosa.

Figura 62: Estruturas de bioturbação nos sedimentos dos diques longitudinais. A: Bioturbação produzida em material argiloso pela infauna; B: Bioturbação produzida em material síltico-arenoso por raízes das plantas (fitoturbação) (imagens da autora). 161

Figura 63: Diagrama de barras de distribuição de frequência das frações granulométricas dos Lagos

Figura 64: Gretas de Contração. A: Exposição no Lago do Tamatá; B: Detalhe da estrutura localizada no Lago do Tamatá; C: Gretas de contração, extremo sul de Anavilhanas; D: Detalhe das gretas. Observar tamanho maior quando comparado com as gretas da prancha B; E: Pelotas de argilas na margem dos lagos; F: Detalhe das pelotas de argila. (imagens da autora). 165

Figura 65: Diagrama de barras de distribuição de frequência das frações granulométricas das Barras Fluviais Centrais e Laterais

Figura 66: Marcas onduladas. A e B: Dunas localizadas nos cordões fluviais; C e D: mirco-ondulações localizadas nas depressões das macro-ondulações. (imagens da autora) 169

Figura 67: Laminação plana em barra fluvial central na Praia do Meio 169

Figura 68: Diagrama de barras de distribuição de frequência das frações granulométricas da Terra Firme

Figura 69: A e B: Estratificação plano-paralela em sedimentos da Formação Alter do Chão - Terra firme; C e D: Estruturas de bioturbação em arenitos da Formação Alter do Chão produzidas por Acaribodó (liposarcus pordolis) (imagens da autora).

Figura 70: Diagrama de Flemming com as amostras da área de pesquisa .173

Figura 71: Carta Geomorfológica do Complexo de Anavilhanas. 176

Figura 72: Cotas máximas e mínimas mensais do ano hidrológico 2010-2011. 190

Figura 73: Variação mensal, em metros, do N.A. referente ao ano hidrológico 2010-2011. 190

Figura 74: Terras caídas. A: Queda das margens em parte de ilha fluvial no Paraná do Sapato; B: Árvores tombadas no Paraná (mesmo local); C: Queda marginal em ilha fluvial; D: Detalhe da imagem anterior; E e F: Quedas marginais e árvores tombadas no curso d'água. (imagens da autora). 


\section{LISTA DE QUADROS}

Quadro 1: Descrição resumida da Geomorfologia Tropical

Quadro 2: Grandes rios do mundo

Quadro 3: Material Cartográfico disponibilizado

Quadro 4: Localização dos pontos de observação e amostragem e número de amostras coletadas

Quadro 5: Localização dos perfis realizados e número de amostras coletadas

Quadro 6: Tipos de sedimentos e classes texturais de sedimentos lamosos de acordo com a classificação de Flemming (2000)

Quadro 7: Estações com dados de chuva no Rio Negro selecionadas 107

Quadro 8: Estações fluviométricas selecionadas

Quadro 9: Dados das Cotas do Rio Negro na Estação de Manaus no período de 1902-2010.

Quadro 10: Dados das cotas nas Estações de Monitoramento Hidrológico na bacia do Rio Negro no período de 1902-2010

Quadro 11: Dados das Cotas do Rio Negro na Estação de Manaus no período de 1902-2012. 127

Quadro 12: Histórico das cheias do sistema Negro/Solimões em Manaus 129

Quadro 13: Classe textural e Tipo de sedimentos para o Perfil 1 de acordo com a classificação de Flemming (2000) 150

Quadro 14: Classe textural e Tipo de sedimentos para a Tradagem de acordo com a classificação de Flemming (2000) 151

Quadro 15: Classe textural e Tipo de sedimentos para o Perfil 2 de acordo com a classificação de Flemming (2000) .153

Quadro 16: Classe textural e Tipo de sedimentos para o Perfil 3 de acordo com a classificação de Flemming (2000) 155

Quadro 17: Classe textural e Tipo de sedimentos para o Perfil 4 de acordo com a classificação de Flemming (2000)

Quadro 18: Classe textural e Tipo de sedimentos para os Diques Longitudinais de acordo com a classificação de Flemming (2000) 160

Quadro 19: Classe textural e Tipo de sedimentos para os Lagos de acordo com a classificação de Flemming (2000) 
Quadro 20: Classe textural e Tipo de sedimentos para as Barras fluviais centrais e laterais de acordo

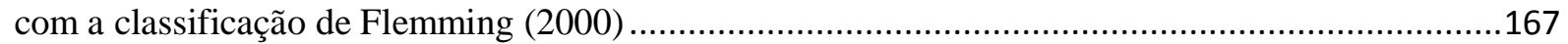

Quadro 21: Classe textural e Tipo de sedimentos para a Terra Firme de acordo com a classificação de Flemming (2000) 


\section{LISTA DE TABELAS}

Tabela 1 - Escala granulométrica de Wentworth (1922).

Tabela 2 - Elementos das Dunas.

Tabela 3 - Dados morfométricos das zonas marginais dos lagos do Prato e Miuá (PIEDADE; JUNK; PAROLIN, 2005).

Tabela 4 - Composição Granulométrica do Perfil 1 (baseada em Wentworth, 1922): 150

Tabela 5 - Composição Granulométrica da Tradagem (baseada em Wentworth, 1922): 151

Tabela 6 - Composição Granulométrica do Perfil 2 (baseada em Wentworth, 1922): 153

Tabela 7 - Composição Granulométrica do Perfil 3 (baseada em Wentworth, 1922): 155

Tabela 8 - Composição Granulométrica do Perfil 4 (baseada em Wentworth, 1922): 157

Tabela 9 - Resultado das Análises Granulométricas para os Diques Longitudinais (baseada em Wentworth, 1922): 159

Tabela 10 - Resultado das Análises Granulométricas Lagos (baseada em Wentworth, 1922): 162

Tabela 11 - Resultado das Análises Granulométricas das Barras fluviais centrais e laterais (baseada em Wentworth, 1922): 166

Tabela 12 - Resultado das Análises Granulométricas Terra Firme (baseada em Wentworth, 1922):..170

Tabela 13 - Processo de evolução de enchentes e vazantes referente ao ano hidrológico 2010-2011 para cotas medidas no Porto de Manaus. 189

Tabela 14 - Número de dias de enchente e vazante relativo ao ano hidrológico 2010-2011: .189 


\section{SUMÁRIO}

1 INTRODUÇÃO

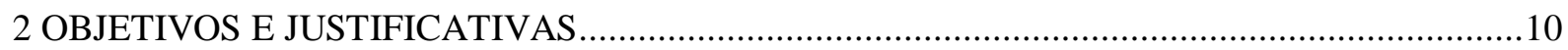

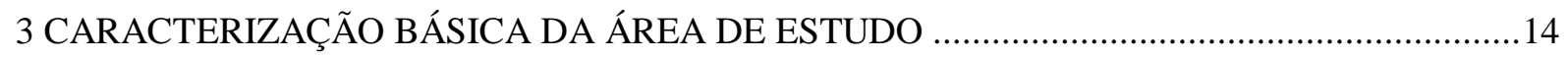

3.1 PARQUE NACIONAL DE ANAVILHANAS - PARNA ANAVILHANAS ...........................14

3.2 ESTRUTURA LITOLÓGICA E TECTÔNICA REGIONAL …................................................19

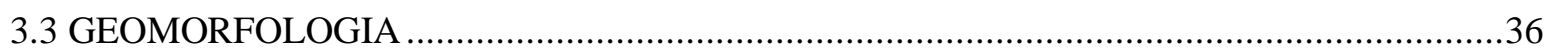

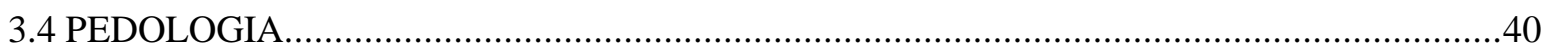

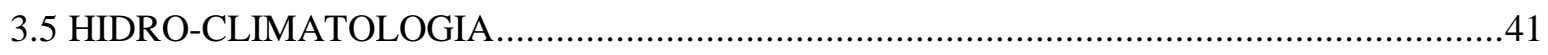

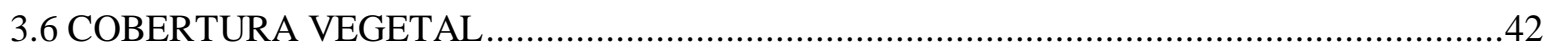

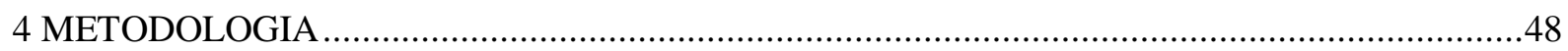

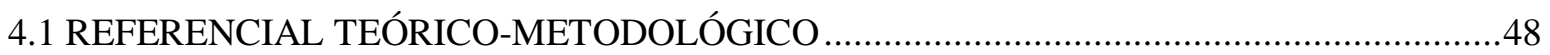

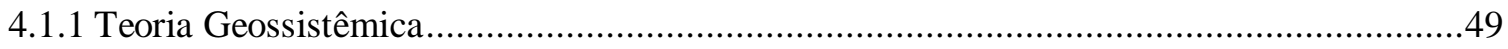

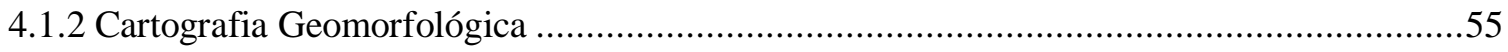

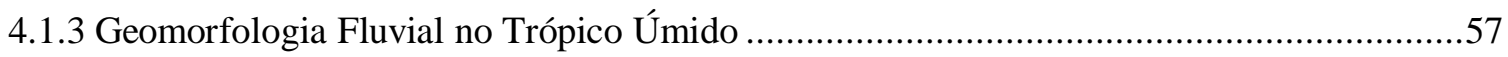

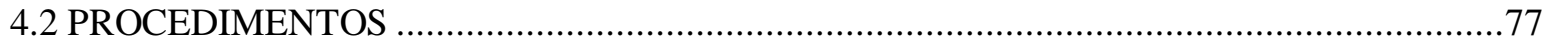

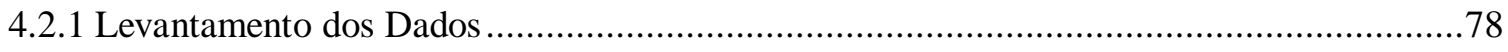

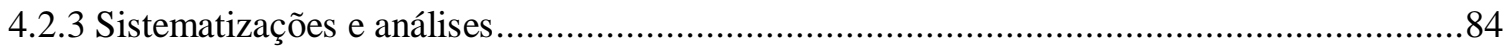

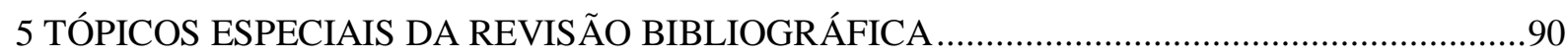

5.1 MORFOGÊNESE DO ARQUIPÉLAGO DE ANAVILHANAS ….....................................90

5.2 GÊNESE DOS PODZÓIS E SUA INFLUÊNCIA NA CARGA E QUALIDADE DAS ÁGUAS

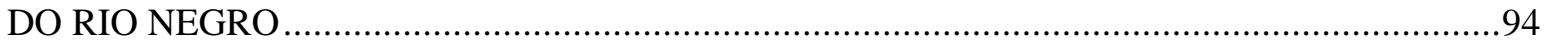

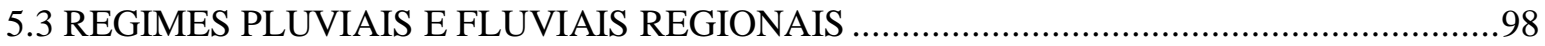

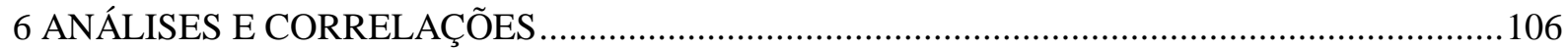

6.1 ANÁLISE HIDROMETEOROLÓGICA DA BACIA DO RIO NEGRO.................................106 


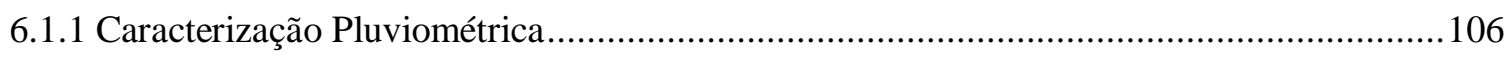

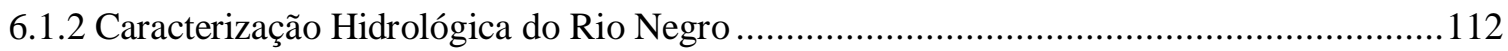

6.2 ANÁLISE DA DINÂMICA ANUAL E DA MAGNITUDE DE ENCHENTES E VAZANTES

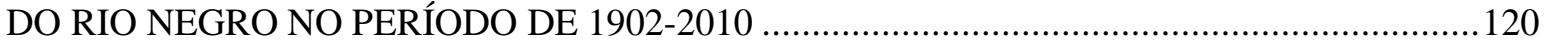

6.3 EVENTO EXTREMO DO RIO NEGRO EM MANAUS EM 2012 .....................................127

6.4 CARACTERIZAÇÃO MORFOLÓGICO-MORFOMÉTRICA............................................134

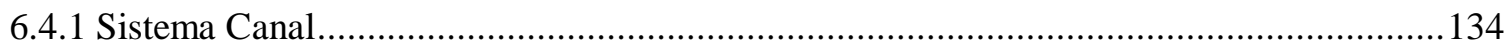

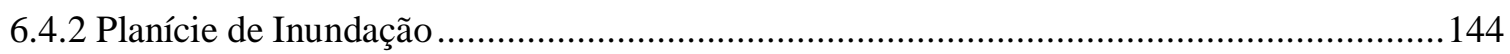

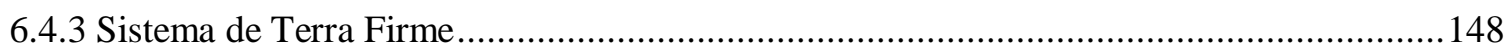

6.5 CARACTERIZAÇÃO SEDIMENTOLÓGICA …..........................................................149

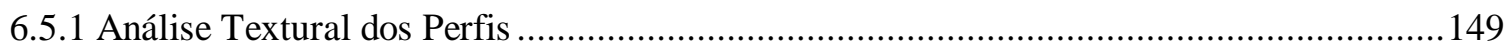

6.5.2 Análise Textural em Pontos Amostrais das Unidades Morfológicas.................................159

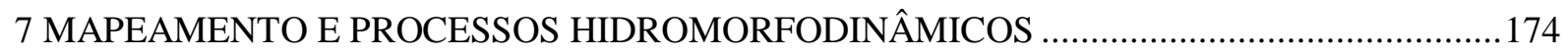

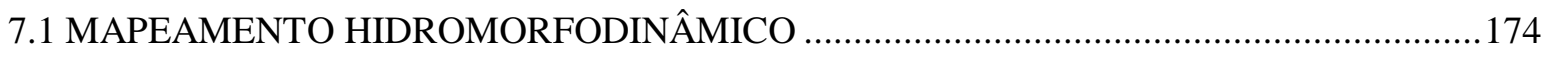

7.1.1 Carta Geomorfológica do Complexo de Anavilhanas ...................................................174

7.2 PROCESSOS HIDROMORFODINÂMICOS E TENDÊNCIAS ESPACIAIS .......................184

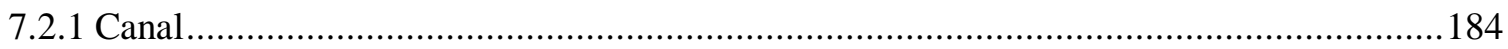

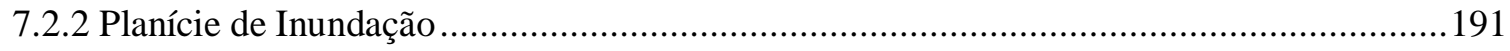

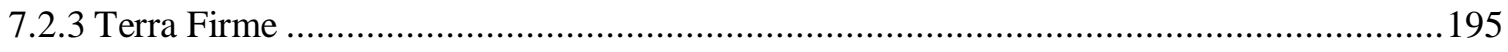

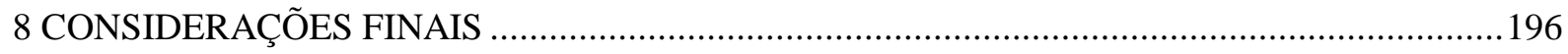

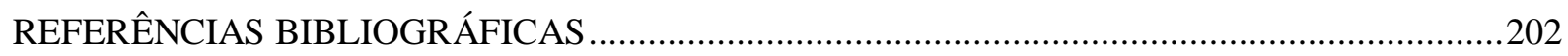




\section{MAPEAMENTO HIDROMORFODINÂMICO DO COMPLEXO FLUVIAL DE ANAVILHANAS. CONTRIBUIÇÃO AOS ESTUDOS DE GEOMORFOLOGIA FLUVIAL DE RIOS AMAZÔNICOS}

\section{INTRODUÇÃO}

O conhecimento dos grandes rios em meio tropical úmido é, ainda hoje, bastante incipiente, principalmente ao se considerar a extensão das regiões tropicais, a magnitude de seus rios, o tamanho de suas bacias hidrográficas e a importância dessas na economia mundial.

As regiões tropicais localizam-se entre $30^{\circ}$ de latitudes sul e norte e apresentam tipos climáticos diversos principalmente marcados pela ausência de estação fria. Pelo fato das temperaturas mostrarem pequena variação nos trópicos, as subdivisões dos climas tropicais são usualmente baseadas no volume e na distribuição da precipitação. Estes elementos climáticos discriminam, por exemplo, o clima tropical chuvoso, o clima tropical de monções, o clima tropical úmido-seco, o semi-árido e o árido (AYOADE, 1996).

O clima tropical chuvoso, ao qual pertence a área de estudo, é também conhecido como clima equatorial ou tropical úmido, predominando nas áreas próximas ao equador e sendo caracterizado por temperaturas elevadas, precipitação pluvial abundante (acima de $1700 \mathrm{~mm} / \mathrm{ano}$ ) e bem distribuída ao longo do ano. Sem estações demarcadas pelas temperaturas, apresenta temperaturas mensais médias de $25-28^{\circ} \mathrm{C}$ e amplitudes anuais médias inferiores a $3^{\circ} \mathrm{C}$.

O clima tropical de monções apresenta estação chuvosa bem definida e os totais anuais da precipitação e temperatura são similares aos do clima tropical chuvoso. O clima tropical úmido-seco tem estações úmidas e secas alternantes em períodos mais ou menos equidistantes. A estação seca é severa e tem um efeito profundo sobre a vegetação (savana) e sobre culturas.

O clima tropical semi-árido e árido apresentam taxas de evaporação elevadas, enquanto a precipitação pluvial anual é baixa com mínimo de $250 \mathrm{~mm}$. As amplitudes de 
temperatura, tanto anual como diurnas, são elevadas, sendo comuns diferenças de $20-25^{\circ} \mathrm{C}$ (AYOADE, 1996).

Os rios tropicais drenam uma variedade de províncias geológico-geomorfológicas por todo o planeta, a exemplo dos planaltos em cinturões orogenéticos, os planaltos ou platôs basálticos, os planaltos e depressões em áreas cratônicas (Tapajós, Xingu e Negro), as planícies em bacias sedimentares (Purus e Juruá) e os terrenos mistos (Araguaia, Madeira, Japurá, Iça e Mamoré). Apresentam regimes fluviais diversos devido à própria complexidade do clima tropical, à imensa extensão das bacias hidrográficas desses rios tropicais e às configurações de algumas destas bacias no sentido latitudinal (LATRUBESSE; STEVAUX; SINHA, 2005).

Os rios que drenam florestas pluviais tropicais como o Purus, Madeira e Negro têm, em geral, comportamento aproximadamente semelhante àqueles de savana tropical úmidaseca e com os monçônicos. Todos exibem altos picos de descarga, todavia, variáveis durante a estação chuvosa e constantes baixas vazões ao longo do período de menores precipitações anuais. Rios tropicais fluviais como o Purus e Juruá mostram valores de variabilidade de descarga superiores àqueles que drenam áreas de savana como o Tocantins, ou de ambientes mistos como o Madalena ou Paraná. Os regimes dos rios tropicais são também afetados pela recorrência de 2-7 anos dos eventos do El Ninõ (ENSO) (LATRUBESSE; STEVAUX; SINHA, 2005).

A bacia do rio Amazonas, a maior bacia hidrográfica do mundo, cobre uma superfície de $6.1 \times 10^{6} \mathrm{~km}^{2}$ correspondente a $5 \%$ das terras emersas continentais do globo, estendendose desde $79^{\circ}$ de longitude Oeste (rio Chamaya, Peru) até $48^{\circ}$ de longitude Oeste (rio Pará, Brasil), e de $5^{\circ}$ de latitude Norte (rio Cotingo, Brasil) a $20^{\circ}$ de latitude Sul (Rio Parapeti, Bolívia). Esta bacia hidrográfica de dimensões continentais abrange territórios de vários países: Brasil (63\% da área da bacia), Peru (17\%), Bolívia (11\%), Colômbia (5.8\%), Equador (2.2\%), Venezuela (0.7\%) e Guyana (0.2\%) (FILIZOLA et al., 2002) (Figura 1). 


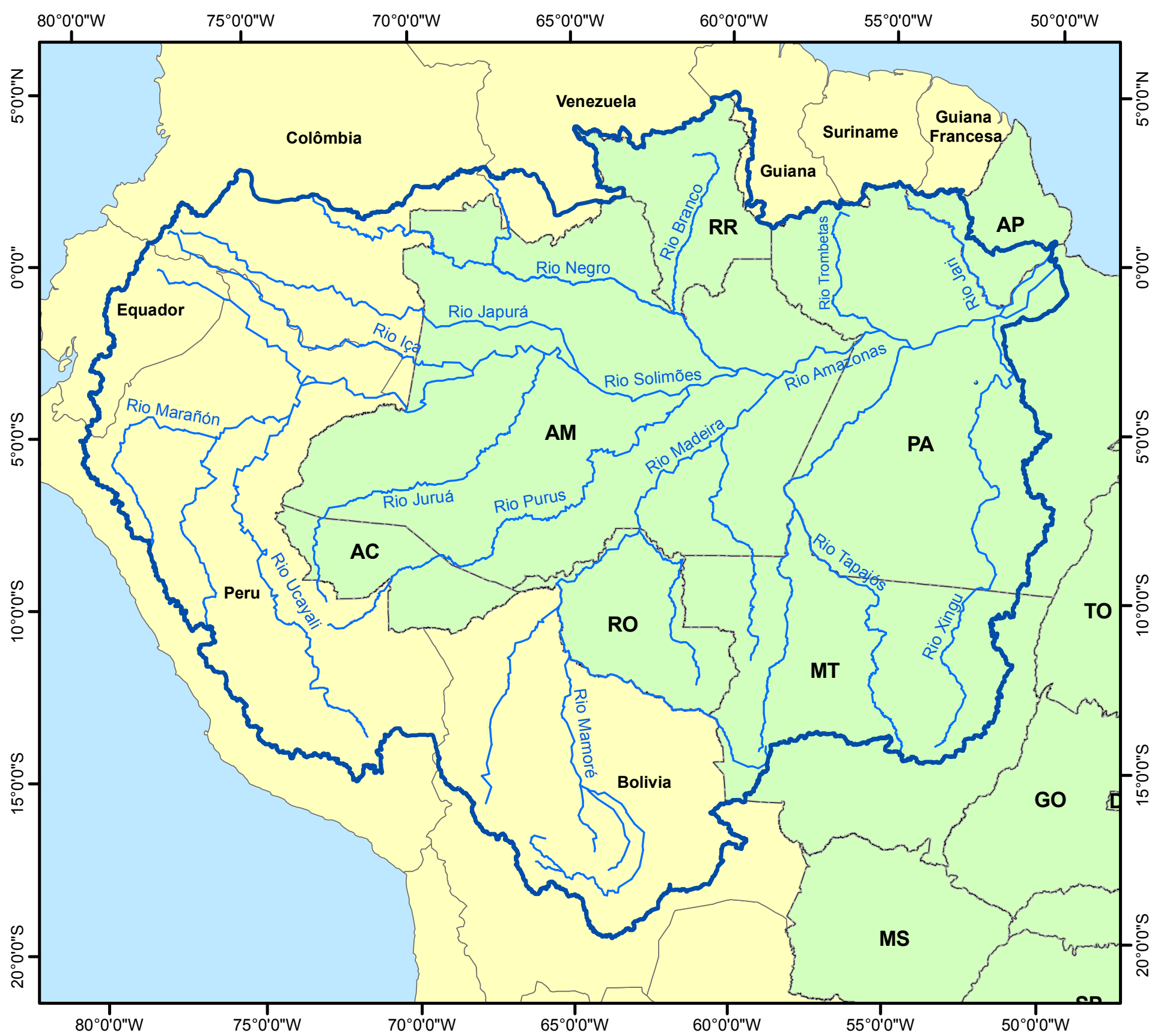

\section{BACIA AMAZÔNICA}

\section{LEGENDA}

\section{Hidrografia}

Limite da Bacia Amazônica

Unidades da Federação - Brasil

Outros Países

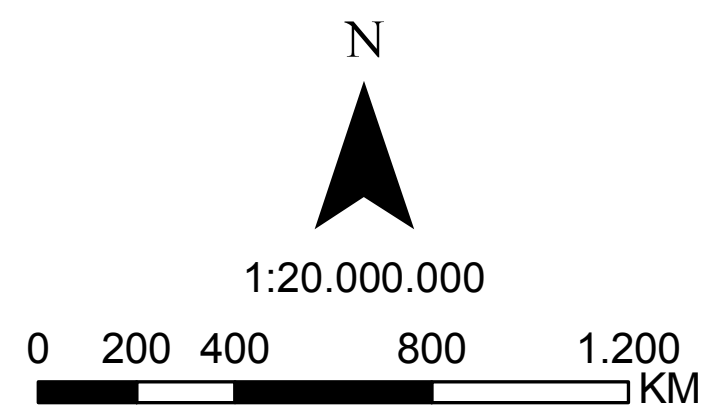

Datum SAD 69

Coordenadas LAT/LONG

IBGE (2006) ; FILIZOLA et al. (2002)

Figura 1: Bacia Hidrográfica do Amazonas 
A Bacia Amazônica aporta ao oceano um volume de água de aproximadamente 6,6. $10^{12} \mathrm{~m}^{3}$.ano ${ }^{-1}$, o que corresponde a cerca de $16 \%$ a $20 \%$ do total das águas doces continentais do globo (MOLINIER et al., 1996). Apresenta características climáticas e topográficas contrastantes. A parte oriental da bacia hidrográfica é caracterizada por uma cadeia de montanhas ativas, os Andes, que correspondem a $12 \%$ da superfície total da bacia. A vasta planície amazônica encontra-se rodeada por terrenos geologicamente muito antigos, do précambriano, correspondentes aos escudos Brasileiro e das Guianas. Englobando toda essas unidades morfoestruturais, o relevo varia desde o nível do mar até mais de 6000m de altitude, a pluviosidade varia de 100 até cerca de $5000 \mathrm{~mm} / \mathrm{ano}$ e a vegetação é em grande parte constituída por 70\% de floresta tropical úmida (FILIZOLA; GUYOT, 2007).

A bacia hidrográfica do Amazonas está submetida a um regime de precipitações essencialmente de origem atlântica, com uma forte reciclagem por evapotranspiração da floresta Amazônica, responsável pela metade do volume precipitado, ou seja, 50\% da água precipitada correspondem a, aproximadamente $50 \%$ de vapor d'água reciclado (SALATI; MARQUES, 1984; MOLINIER et al., 1996) e recebe em média 2.460 mm/ano. Na parte brasileira da bacia, a distribuição sazonal das precipitações demonstra diferenças sensíveis entre o Norte e o Sul. Ao Norte do equador (bacia do Rio Negro), o máximo pluviométrico é observado de maio a julho enquanto que ao Sul da bacia é de dezembro a março. Nos Andes bolivianos, a topografia exerce uma forte influência sobre a pluviometria, com valores extremos de $6000 \mathrm{~mm} / \mathrm{ano}$ e de $300 \mathrm{~mm} / \mathrm{ano}$ em alguns vales intermontanos. Na parte ocidental e equatorial da bacia e principalmente sobre os contrafortes dos Andes peruanos, equatorianos e colombianos, o regime sazonal das precipitações é caracterizado por uma distribuição bimodal, ou seja, com duas estações de chuva, uma de abril a junho e a outra de agosto a novembro (ROCHE et al., 1992; JOHNSON, 1976 apud FILIZOLA et al., 2002).

A água é fator preponderante da paisagem Amazônica, seja do ponto de vista das precipitações, como do ponto de vista dos rios e sua dinâmica. A região é constituída por rios de grande porte, rios pequenos e igarapés, apresentando diferenças consideráveis em relação à morfologia e composição de seus leitos e quanto às características químicas e biológicas de suas águas. O entendimento desta diversidade passa por uma discussão não somente dos aspectos biológicos das Águas Amazônicas, mas também por uma discussão das condições 
geomorfológicas, pedológicas, geológicas, hidrológicas e hidroquímicas da região inteira (JUNK, 1983).

\begin{abstract}
"São simplesmente fantásticos os números referentes à área de extensão da bacia, volume das águas correntes, a largura média dos leitos e o débito dos grandes rios em diferentes setores. Calcula-se a área total da bacia de mais de seis milhões de quilômetros quadrados. Na Bacia Amazônica, vista em sua totalidade, circulam 20\% das águas doces existentes no planeta." (AB'SABER, 2003, p.67).
\end{abstract}

Os rios da Amazônia distribuem-se na porção centro-norte da América do Sul e drenam a maior floresta tropical da Terra. Os furos e igarapés também têm grande importância dentro desse complexo hidrográfico. O furo é um canal, sem correnteza própria, que corta uma ilha fluvial, liga rios no meio de planícies, liga rio com lago de várzea, liga um paraná com o rio principal ou com uma depressão de lago de várzea. O Paraná é um extenso, largo e profundo braço de rio e pode ser considerado um riacho de menor dimensão. Na bacia do Rio Negro a maioria dos igarapés apresenta águas escuras devido à quantidade de matéria orgânica transportada e por receberem pouca luminosidade solar. Nas cheias, suas águas podem fluir por verdadeiros túneis de vegetação. O termo igarapé vem dos vocábulos indígenas "igara" (que é a canoa escavada em um tronco de árvore) e "apé ou pé" (que significa caminho).

Segundo Ab’Saber (2003), a toponímia de rios amazônicos é rica em discriminar diversos tipos de canais e de sua dinâmica hídrica, possuindo inegável valor científico, conforme a seguir:

Quando agregados a um topônimo, como acontece na maioria das vezes, as designações passam a ter, para o habitante, um caráter referencial principalmente para quem não dispunha de qualquer tipo de mapa ou carta, tampouco conhecia os padrões regionais da drenagem em sua totalidade espacial. Cada homem ou comunidade, em seu pequeno espaço de vivência, reconhecia o lugar do seu entorno pelos nomes herdados dos indígenas e tornados tradicionais por pescadores, mateiros, seringueiros, castanheiros e beiradeiros (Furo da Onça, Paraná dos Ramos, Baía das Bocas, Furo de Breves, Canal Perigoso). Os critérios embutidos nas classificações populares dos componentes da drenagem amazônica tem valor científico. O povo da Amazônia reconhece tipos de rios pela cor das águas, pela ordem de grandeza dos cursos d'água, por sua largura, volume e posição fisiográfica, assim como pelo sentido, continuidade e duplicidade da correnteza (AB'SABER, 2003, p. 69). 
Junk (1983) classifica as Águas Amazônicas em 03 tipos principais: águas brancas, águas pretas e águas claras e esta classificação vem sendo tradicionalmente utilizada na maior parte das referências aos rios amazônicos. Os rios de águas brancas (Amazonas, Purus, Madeira e Juruá) nascem na região Andina e pré-andina e possuem uma elevada carga de sedimentos em suspensão devido aos intensos processos erosivos nos Andes, provocando a cor branca das águas. Os rios de águas pretas (Negro, Urubu), nascem nos escudos arqueanos das Guianas e Brasil Central ou nos sedimentos terciários da bacia Amazônica, e não transportam material em suspensão em grande quantidade. Os rios de águas claras são transparentes e com cor esverdeada, transportando baixa carga em suspensão.

Em função do fato de que há uma significativa variabilidade sazonal na concentração de substâncias húmicas e na quantidade de sedimentos transportados durante o período de chuvas na Região Amazônica, Junk (1983) conclui que é possível considerar, de forma simplificada, a existência de dois tipos de águas nitidamente diferentes e com características bem específicas: água branca, que é turva, rica em sais minerais dissolvidos, com alta percentagem de cálcio e magnésio, neutra ou pouco ácida e água preta, que é transparente, escura, pobre em sais dissolvidos, com alta percentagem de sódio e potássio e muito ácida.

As florestas inundáveis pelos rios de água branca, com maior fertilidade, são regionalmente denominadas de várzeas e aquelas associadas aos rios de água claras ou pretas, com $\mathrm{pH}$ baixo e pobres em nutrientes, de igapós. Dentre os igapós de água preta, aqueles ao longo do rio Negro são os mais típicos representantes (PRANCE, 1980). Isto se aplica à região, mesmo considerando que o conceito geomorfológico de várzea implicaria em incluir o igapó.

A bacia Hidrográfica do Rio Negro estende-se pela Colômbia, Venezuela, Guiana e Brasil, abrangendo uma área de $696.810 \mathrm{~km}^{2}$ coberta em quase sua totalidade por uma floresta tropical (Figura 2). O clima é tropical úmido com uma precipitação média maior que 2000 $\mathrm{mm} /$ ano com um aumento na direção NW atingindo aproximadamente $3500 \mathrm{~mm} / \mathrm{ano}$. Este rio apresenta uma descarga média anual de $29.000 \mathrm{~m} 3 / \mathrm{s}$, carrega, em média, 8 milhões de toneladas anuais de sedimentos suspensos, sendo 50\% de sua carga constituída de matéria orgânica (FILIZOLA, 1999). Sua coloração escura é, em parte, devido à drenagem dos solos ricos em solutos húmicos, provenientes da matéria orgânica em decomposição da floresta, o 
que, inclusive, faz parte da gênese dos podzóis, que predominam na porção noroeste da bacia (LEENHEER; SANTOS, 1980; NASCIMENTO, N. R. et al., 2004).

O regime hidrológico do Rio Negro é do tipo Equatorial, caracterizado pela ocorrência de dois picos máximos de descarga durante o ano. O primeiro pico ocorre nos primeiros noventa dias do ano, fraco e de amplitude baixa. O segundo e maior pico corresponde à inundação anual, que ocorre no período de maio a julho (FILIZOLA et al., 2009).

Ao longo do seu curso até a sua confluência com o rio Solimões podem-se distinguir três setores morfológicos, fortemente influenciados pelo substrato geológico: o alto Rio Negro, na área de embasamento cristalino, o médio curso, em depósitos cenozóicos até a confluência do Rio Branco, onde volta a aflorar o embasamento cristalino e o canal do rio é mais estreito, e o baixo curso localiza-se em rochas mesozóicas da Formação Alter do Chão. Em seu médio e baixo curso o Rio Negro apresenta um sistema de barras fluviais ou ilhas que compõem os arquipélagos de Mariuá e das Anavilhanas, respectivamente (FRANZINELLI; LATRUBESSE, 2003).

A pesquisa realizada tem como objetivo central a cartografação de sistemas geomorfológicos do canal do Rio Negro e das ilhas fluviais no Complexo Fluvial de Anavilhanas, para a identificação de tendências espaciais de processos hidromorfodinâmicos em diferentes períodos do ano hidrológico. Dentre estes processos, estão contidos os de sedimentação e de erosão em cada sistema ou unidade morfológica cartografada, incluindo-se processos relativos a sistemas lacustres sazonais.

Busca-se esta interpretação de processos atuais, a partir do cruzamento de informações cartográficas da morfologia, de levantamentos e análises sedimentológicas e de parâmetros hidrológicos para a área do Complexo de Anavilhanas. O principal instrumental de pesquisa para esta articulação é, ao mesmo tempo, um produto e meio de pesquisa: a cartografia geomorfológica de detalhe, na escala 1:100.000, da área de estudo.

A área de estudo, Complexo de Anavilhanas, localiza-se no baixo curso do rio Negro e compreende parte do Parque Nacional de Anavilhanas nos municípios de Novo Airão e de Manaus, na Amazônia Ocidental. 


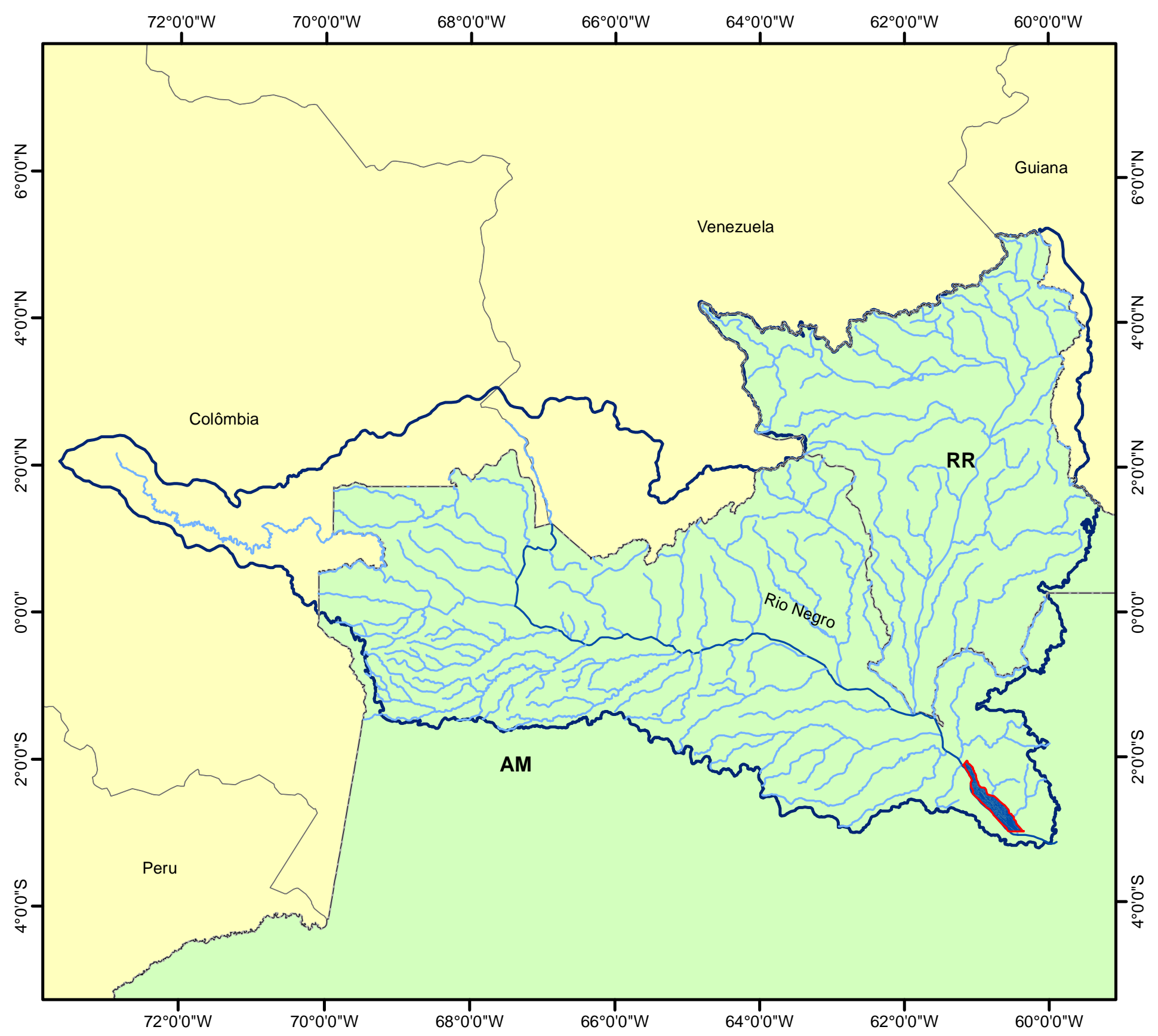

BACIA DO RIO NEGRO

\section{LEGENDA}

Hidrografia

$\sim$ Rio Negro

$\square$ Limite da Bacia do Rio Negro Área de Estudo

Unidades da Federação - Brasil

Outros Países

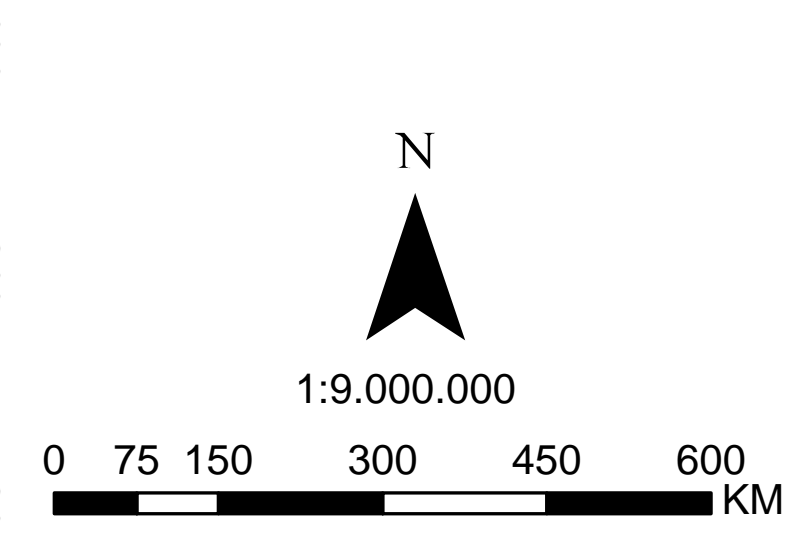

Datum SAD 69

Coordenadas LAT/LONG IBGE (2006)

Figura 2: Bacia Hidrográfica do Rio Negro 
A tese aqui proposta é a de que a dinâmica sazonal dos processos de cheias, inundações e vazantes, apesar de apresentar alta magnitude do ponto de vista hidrológico e do volume de material mobilizado, confere à morfologia do Complexo uma estabilidade significativa e que a tendência evolutiva de seu balanço morfogenético holocênico parece estar ligada à uma ligeira degradação/erosão de seus trechos de jusante.

Outra proposição a ser testada neste estudo é a de que os estudos tradicionais de Geomorfologia, que desembocam na Cartografia e na articulação de campos do conhecimento das Ciências da Terra, aplicam-se aos grandes rios amazônicos na descoberta de tendências espaciais de processos; e que os levantamentos, assim articulados, permitirão tecer hipóteses a respeito da morfogênese do complexo.

A construção desta pesquisa tem sua origem no ingresso no Programa de Doutorado Interinstitucional - DINTER do Programa de Pós-Graduação em Geografia Física da FFLCH/USP, um convênio da Universidade de São Paulo - USP com a Universidade do Estado do Amazonas - UEA. Seu desenvolvimento e definição temática fundamentam-se no fato de que existem lacunas no conhecimento de Geomorfologia Fluvial dos rios amazônicos e que, estas lacunas, podem comprometer até mesmo os objetivos de conservação de seu território. Também colaborou para esta definição temática a existência de grupo de estudo de Geomorfologia Fluvial Aplicada a rios amazônicos junto à Universidade de São Paulo. 


\section{OBJETIVOS E JUSTIFICATIVAS}

A pesquisa objetivou caracterizar tendências espaciais de processos hidromorfodinâmicos no Complexo Fluvial de Anavilhanas, na região do baixo curso do rio Negro, Amazonas, produzindo-se a cartografia hidromorfodinâmica dessa área, apoiada na articulação de informações morfológicas, hidrológicas, sedimentológicas e de cobertura vegetal em áreas amostrais.

Como objetivos secundários necessários à produção desta pesquisa, buscou-se:

1) Localizar, mapear e caracterizar a morfologia fluvial e flúvio-lacustre do sistema fluvial complexo de Anavilhanas;

2) Descrever as características dos materiais superficiais predominantes de Anavilhanas e das margens do rio Negro (Terra Firme) e a distribuição espacial destes materiais e, por meio dos recursos da geologia sedimentar, estabelecer sua relação com os pulsos de cheias e de inundações observados na área ao longo do ano, observando-se parâmetros como dados texturais, estruturas sedimentares, aspectos estratigráficos e morfométricos.

3) Interpretar e, posteriormente, mapear tendências espaciais desses processos hidrodinâmicos por meio de correlação das informações morfológicas, hidrológicas e sedimentológicas observadas;

4) Analisar as tendências atuais dos processos hidrodinâmicos de cheias e vazantes do rio Negro na área de estudo;

5) Colaborar com interpretações paleogeográficas e morfogenéticas a respeito da origem dos materiais caracterizados;

6) Colaborar para o reconhecimento da dinâmica de sub-sistemas fluviais e sua importância para objetivos de conservação e manejo do Parque Nacional de Anavilhanas.

A Geomorfologia Fluvial nos estudos relacionados com os canais fluviais procura discernir os arranjos e conexões espaciais, evidenciando tendências de processos que se apresentam ao longo desses sistemas. No caso específico da Amazônia o uso de imagens do projeto RADAMBRASIL associadas a imagens de satélites vem, desde a década de 60, proporcionando informações das principais drenagens da bacia Amazônica, auxiliando a 
desvendar padrões fluviais, a exemplo de estilos de canal, como o meandrante, entrelaçado, retilíneo e anastomosado (BAKER, 1978) e anabranches (NANSON; KNIGHTON, 1998).

Em ambientes tropicais úmidos, como no caso da Amazônia, em que estudos em geomorfologia fluvial ainda são incipientes, esta tarefa é mais complexa, devido à dificuldade de obtenção de dados fluviométricos, sedimentológicos, pedológicos, geológicos e geomorfológicos. A essa dificuldade, não só imposta pela grande dimensão da área e o restrito acesso, acrescenta-se a densa cobertura vegetal e baixo relevo, que resultam em carência de exposições naturais. Os estudos disponíveis são de natureza regional ou pontual, desfavorecendo discussão aprofundada que aborde aspectos relevantes ao entendimento da evolução do sistema de drenagem, como idade e forma de instalação, abrangência dos depósitos sedimentares resultantes, e magnitude dos possíveis fatores controladores (HAYAKAWA et al., 2010).

Para a área que compreende a Amazônia Central e os seus principais sistemas fluviais, grande parte das informações geológicas e geomorfológicas disponíveis provém de estudos regionais realizados pelo Projeto RADAMBRASIL na década de 70. O Projeto RADAM, depois de 1970, realizou a cobertura de toda a Amazônia com imagens de Radar, mosaicos semi controlados na escala 1:250.000, que forneceram uma excelente imagem dos principais cursos d'água da região (TRICART, 1977a). A maioria dos estudos existentes são pontuais, de escala regional e ainda insuficientes para se inferir sobre a dinâmica geomorfológica atual dos sistemas fluviais e flúvio-lacustres. Este estudo pretende ampliar esse nível de detalhamento para a escala 1:100.000, reconhecendo-se áreas com diferentes tendências hidrodinâmicas (águas turbulentas, margens de solapamento, ambientes lóticos e sua variabilidade anual, dentre outros conteúdos).

No baixo curso do rio Negro, nos municípios de Novo Airão e de Manaus, o canal fluvial apresenta-se num imbricado e complexo padrão composto por centenas de ilhas, lagos, canais, pântanos e bancos de areias parcialmente submersos, mais evidentes durante os períodos de vazante (setembro-outubro-novembro), formando o local denominado de “Arquipélago de Anavilhanas", o segundo maior agrupamento de ilhas fluviais do mundo. O padrão anastomosado predominante na área é marcado por formas longitudinais de grandes dimensões separadas por uma diversidade de padrões de furos, paranás e igarapés, exemplos típicos que caracterizam a tipologia de canais múltiplos cujo conhecimento incipiente da 
dinâmica fluvial local demanda estudos mais aprofundados da área. O conhecimento das características fluviais é importante do ponto de vista dos recursos hídricos, sedimentológico, geomorfológico, do planejamento regional e da conservação ambiental.

A área do Arquipélago de Anavilhanas nos municípios de Novo Airão e Manaus foi selecionada como objeto de estudo devido a algumas características singulares, tais como: o complexo e imbricado padrão formado por cerca de 400 ilhas, furos, paranás, lagos e igarapés, numa extensão aproximada de $90 \mathrm{~km}$ e 12,5 km de largura máxima, cujas ilhas apresentam peculiaridades como a sazonalidade anual dos períodos de vazantes e inundações que chegam a 06 meses durante o ano. Isto determina para a biota local a presença de uma fase aquática e terrestre, com implicações diretas no padrão de distribuição da vegetação e dinâmica fluvial.

Outro importante aspecto que justifica a escolha da área para estudo é o elevado índice de preservação ambiental. A área abrange parte do Parque Nacional de Anavilhanas, Unidade de Conservação de Proteção Integral (SNUC, 2000) que tem como um dos objetivos principais estimular a produção de conhecimento através da pesquisa científica. Este estudo pretende contribuir na geração de conhecimento geológico-geomorfológico para a unidade de conservação que provavelmente estará colaborando na preservação e conservação de rios amazônicos.

A localização da área, próxima à confluência dos rios Negro e Solimões, no local denominado de "encontro das águas", onde, a partir deste, juntam-se para formar o rio Amazonas, apresenta-se como uma justificativa adicional para a escolha da área tendo em vista a característica peculiar de foz afogada do rio interferindo no padrão morfológico e hidrodinâmico deste. Este efeito de barramento hidráulico do rio Solimões sobre o rio Negro é bastante intenso e pode ser observado da foz até a sua confluência com o rio Branco, distante cerca de 300 quilômetros a montante. Assim, a partir da desembocadura do rio Branco, as flutuações do nível de água do rio Negro refletem principalmente as variações ocorridas no sistema Solimões-Amazonas. Uma das teses desta pesquisa é que, provavelmente, este fenômeno de barramento hidráulico contribuiu para a sedimentação e formação das ilhas do Complexo de Anavilhanas.

A ausência de conhecimentos geológico-geomorfológicos em escala de semi-detalhe tal como 1:100.000 e 1:250.000, associadamente à existência de pesquisas de caráter 
ecológico relativas ao padrão de distribuição de vegetação e caracterização ou estudos relacionados à origem tectônica das ilhas, foram fatores determinantes na seleção da área de estudo. Assim, este estudo pretendeu contribuir para o aumento destes conhecimentos geológicos-geomorfológicos para a área do complexo de Anavilhanas e dos rios amazônicos, no caso específico, do rio Negro. 


\section{CARACTERIZAÇÃo BÁSICA DA ÁREA DE ESTUDO}

A área objeto deste estudo, Arquipélago de Anavilhanas, localiza-se nos municípios de Manaus e Novo Airão, no Estado do Amazonas, entre as coordenadas geográficas: $2^{\circ} 03^{\prime} 00^{\prime} \mathrm{S}$ e $3^{\circ} 02^{\prime} 00^{\prime} \mathrm{S}$ de latitude sul e $60^{\circ} 21^{\prime} 00^{\prime \prime} \mathrm{W}$ e $61^{\circ} 12^{\prime} 00^{\prime \prime} \mathrm{W}$ de longitude oeste, num total de 212.787 hectares. Sua delimitação foi definida adotando-se os limites, Norte e Sul, da Unidade de Conservação, o Parque Nacional de Anavilhanas, nas partes leste e oeste utilizouse a própria margem do canal principal.

O acesso à área, a partir de Manaus, é realizado pela ponte sobre o Rio Negro que liga Manaus à cidade de Iranduba, na margem direita do rio, e, após a ponte, pela rodovia Manuel Urbano - AM-070 (Manaus-Manacapuru). No km 83, após o balneário do Miriti, toma-se a rodovia AM-352 (Manacapuru-Novo Airão) até o município de Novo Airão localizado a cerca de $90 \mathrm{~km}$. O acesso às ilhas de Anavilhanas é feito em pequenas embarcações a motor que ficam atracadas próximas ao porto fluvial da cidade e são utilizadas pelos turistas que frequentam a região (Figura 3).

\subsection{PARQUE NACIONAL DE ANAVILHANAS - PARNA ANAVILHANAS}

O Sistema Nacional de Unidades de Conservação - SNUC classifica as Unidades de Conservação em dois grupos: Unidades de Proteção Integral e de Uso Sustentável (Lei n . 9.985/2000).

As unidades de Proteção Integral têm como objetivo básico preservar a natureza, livrando-a, o quanto possível, da interferência humana. Nelas, como regra, só se admite o uso indireto dos recursos naturais, isto é, aquele que não envolve consumo, coleta, dano ou destruição, com exceção dos casos previstos na Lei do SNUC. Compreendem as seguintes categorias: Estação Ecológica (ESEC), Reserva Biológica (REBIO), Parque Nacional (PARNA), Monumento Natural (MN) e Refúgio de Vida Silvestre (REVIS). 

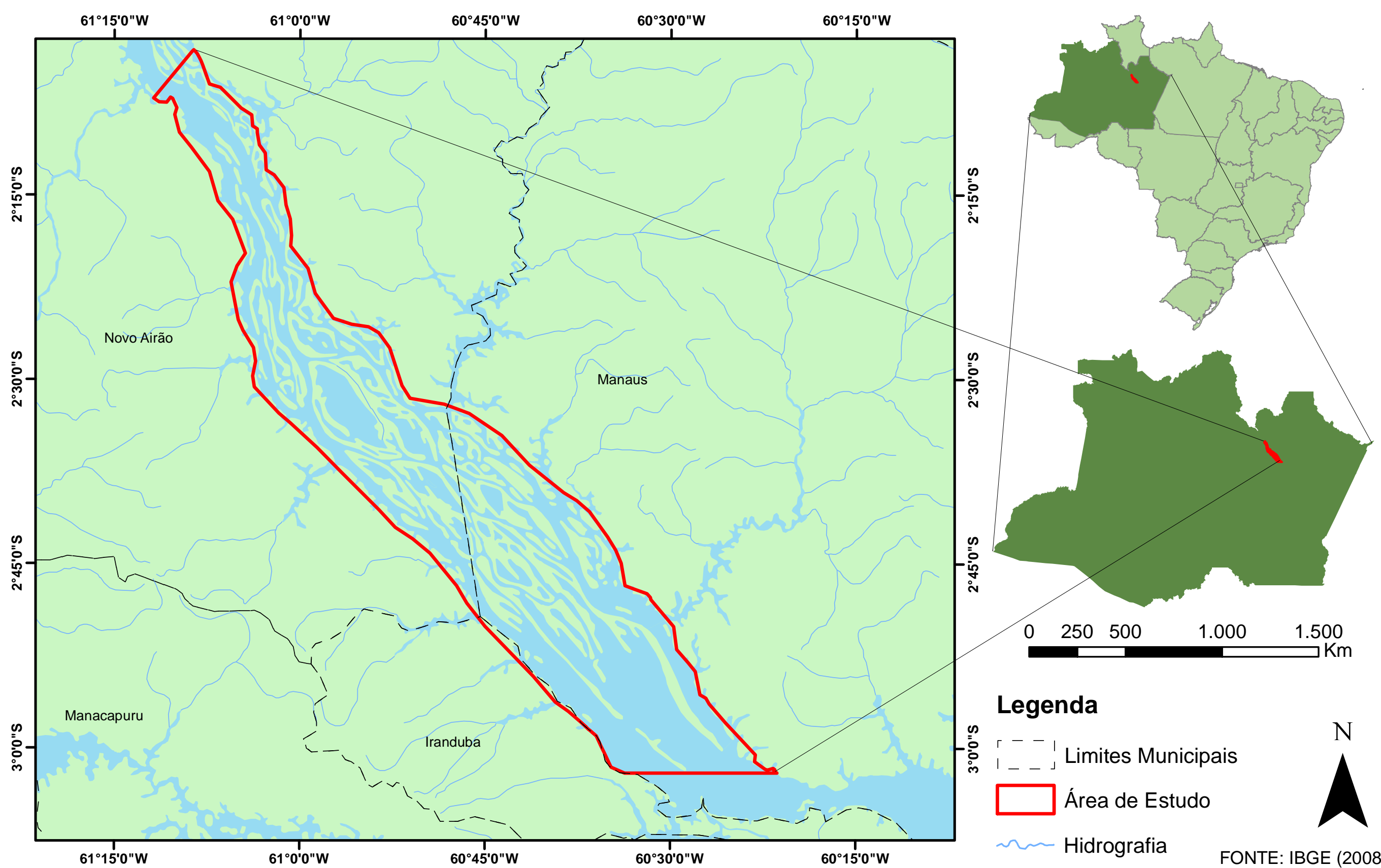

\section{Legenda}

Limites Municipais

$\square$ Área de Estudo

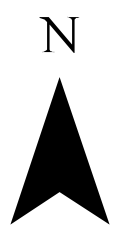

$\sim$ Hidrografia

FONTE: IBGE (2008)

Figura 3: Mapa de Localização da Área de Pesquisa 
As Unidades de Uso Sustentável são aquelas Unidades de Conservação cujo objetivo básico é o de compatibilizar a conservação da natureza com o uso sustentável de parcela de seus recursos naturais. Elas visam conciliar a exploração do ambiente com a garantia de perenidade dos recursos naturais renováveis considerando os processos ecológicos, de forma socialmente justa e economicamente viável. Constituem este grupo as seguintes categorias: Área de Proteção Ambiental (APA), Área de Relevante Interesse Ecológico (ARIE), Floresta Nacional (FLONA), Reserva Extrativista (RESEX), Reserva de Fauna (REFAU), Reserva de Desenvolvimento Sustentável (RDS) e Reserva Particular do Patrimônio Natural (RPPN).

Dentre o grupo de Proteção Integral a categoria de Parque Nacional (PARNA) são unidades de proteção integral que, segundo a legislação brasileira, tem como objetivo central preservar ecossistemas de grande relevância ecológica e beleza cênica, possibilitando a realização de pesquisas científicas, de atividades educacionais e de interpretação ambiental, de recreação e de turismo ecológico, por meio do contato com a natureza.

O Parque Nacional de Anavilhanas - PARNA de Anavilhanas foi criado com o objetivo de preservar o arquipélago fluvial de Anavilhanas bem como suas diversas formações florestais, estimular a produção de conhecimento através da pesquisa científica e promover a valorização da importância do Parque Nacional para conservação através da educação ambiental e turismo sustentável, buscando harmonizar as relações entre as comunidades do entorno e a unidade com ações de bases sustentáveis.

A Estação Ecológica de Anavilhanas foi criada pelo Decreto $n^{\circ} 86.061$ de 02 de junho de 1981. A Unidade foi recategorizada de Estação Ecológica para Parque Nacional pela Lei 11.799 de 29 de outubro de 2008.

O Arquipélago de Anavilhanas está localizado próximo à confluência dos rios Negro e Solimões. É considerado o segundo maior agrupamento de ilhas fluviais do mundo, constituído por mais de 400 ilhas e 600 lagos. São ilhas, lagos, canais, paranás, furos e bancos de areia. Essas ilhas são alongadas, de formato relativamente triangular, com uma região 
"litoral" de deposição de material e uma região de barranco ${ }^{2}$, este último sistematicamente escavado pelas águas do Rio Negro segundo Leenheer e Santos (1980).

O PARNA Anavilhanas abrange parte dos municípios de Novo Airão e Manaus (AM), numa área total de 342.375 hectares (Figura 4). A Unidade de Conservação apresenta formações vegetais diversas, tais como: Floresta Densa com cobertura uniforme, Floresta Ombrófila Densa, Campinarana Arbórea (terra firme), vegetação Caatinga-gapó e chavascal, além de ecossistemas fluviais e lacustres (ICMBio, 2011).

As diferentes formações vegetais aliadas à dinâmica fluvial contribuem para a elevada biodiversidade e endemismo do arquipélago. Em Anavilhanas foram registradas cerca de 500 espécies de peixes, bem como diversas espécies de pássaros e insetos e animais de grande porte. O parque abriga espécies como o peixe-boi (Trichechus inunguis), a onça pintada (Panthera onca), a ave Choquinha do Tapajós (Myrmotherula klagesi), a Arpia (Harpia harpyja), o pirarucu (Arapaima gigas), botos vermelhos (Inia geoffrensis), tucuxis (Sotalia fluviatilis), lontras (Lutra longicaudis), ariranhas (Pteronura brasiliensis), tamanduá (Myrmecophaga trytactyla), anta (Tapirus terrestris) e diversas espécies de quelônios e jacarés (Figura 5).

\footnotetext{
${ }^{1}$ No original, este termo parece significar a parte basal das margens fluviais, nas quais aparecem pequenos depósitos arenosos.

${ }^{2}$ Este termo parece significar margens de alta declividade
} 


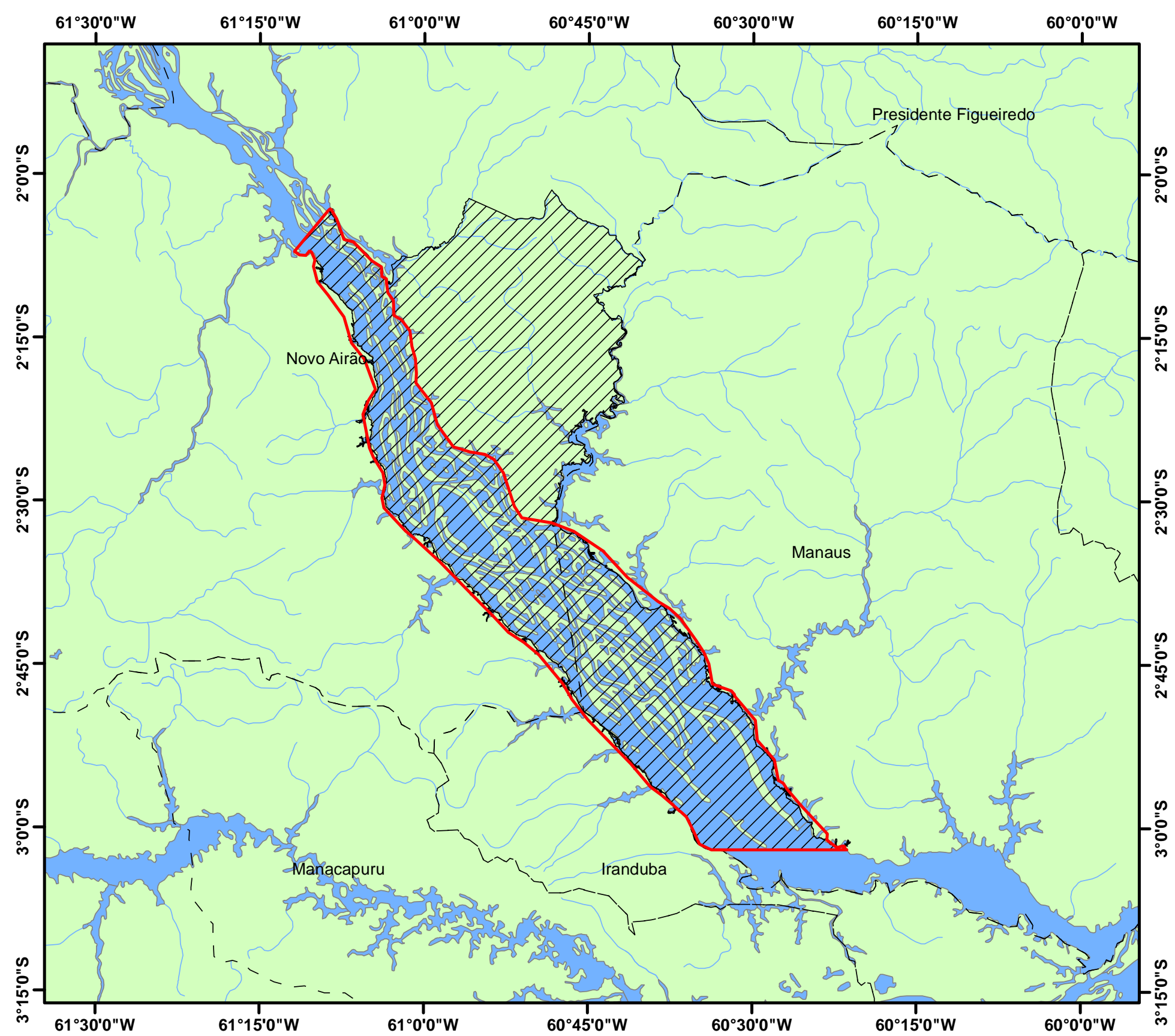

\section{PARQUE NACIONAL DE ANAVILHANAS}

\section{LEGENDA}

$\left\ulcorner_{-}-\right.$Limites Municipais

:

ZI/ Parque Nacional de Anavilhanas

$\square$ Área de Estudo

Hidrografia

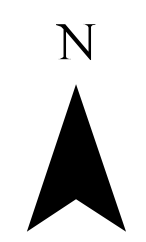

$1: 1.000 .000$

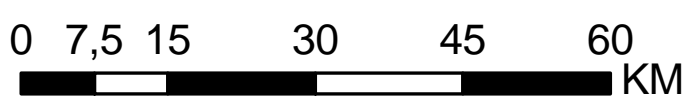

Datum SAD 69

Coordenadas LAT/LONG CPRM (2008)

Figura 4: Unidade de Conservação PARNA de Anavilhanas (AM) 

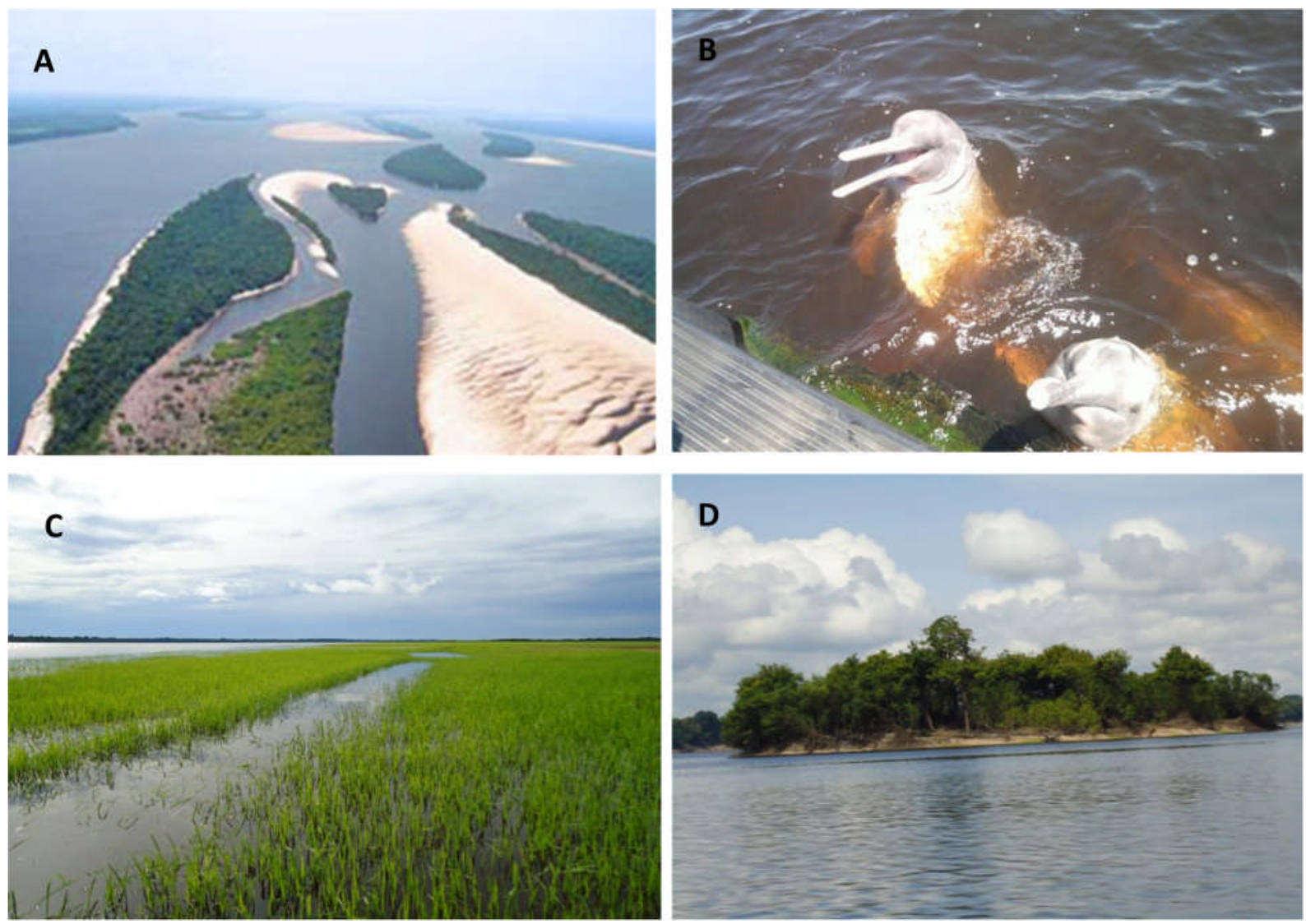

Figura 5: A: Parque Nacional de Anavilhanas (Fonte: www.icmbio.gov.br); B: Botos tucuxis (Sotalia fluviatilis); C: Ecossistema Lacustre; D: Ilha fluvial (imagens da autora)

\subsection{ESTRUTURA LITOLÓGICA E TECTÔNICA REGIONAL}

A área de pesquisa está inserida na Bacia Sedimentar do Amazonas, que é uma bacia intracratônica com cerca de $500.000 \mathrm{~km}^{2}$, abrangendo parte dos estados do Amazonas e Pará. É limitada ao norte pelo Escudo das Guianas e ao sul pelo Escudo Brasileiro (Figura 6) abarcando as anteriormente denominadas bacias sedimentares do Médio e Baixo Amazonas (CAPUTO, 1984). É limitada a oeste com a Bacia do Solimões pelo Arco de Purus, ao passo que o Arco de Gurupá constitui seu limite leste com a Bacia de Marajó. Duas sequências de primeira ordem podem ser reconhecidas nos $5.000 \mathrm{~m}$ do preenchimento sedimentar da Bacia do Amazonas: uma paleozoica, intrudida por diques e soleiras de diabásio, e uma mesozoicocenozoica. 


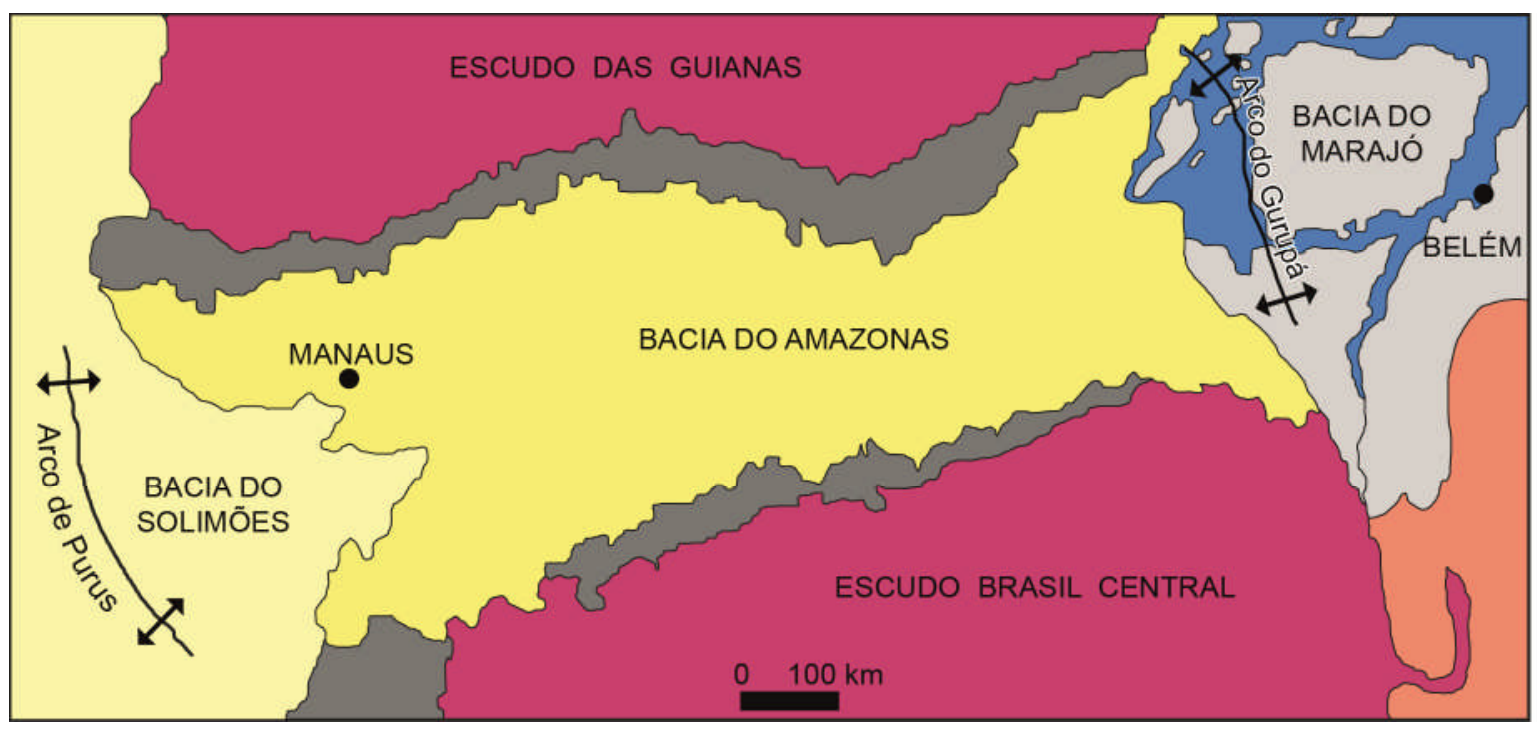

\section{LEGENDA}

Bacia do Marajó

Bacia do Solimões

Bacia do Amazonas (Mesozoico)

Bacia do Amazonas (Paleozoico)

Província Tocantins

Cráton Amazônico

Escudo Brasil Central e das Guianas

Figura 6: Contexto geotectônico da Plataforma Sul-Americana e a Bacia do Amazonas

Fonte: SILVA, C. L., 2005 
O registro sedimentar e ígneo da Bacia do Amazonas reflete os eventos tectônicos paleozoicos ocorrentes na borda oeste da pretérita placa gonduânica e da trafogenia mesozoica do Atlântico Sul. Estes fenômenos orogênicos provocaram movimentações epirogênicas intraplaca, resultando na formação de arcos de grande porte e discordâncias regionais, além de controlarem as ingressões marinhas que influenciaram os ambientes deposicionais (CUNHA et al., 1994).

O substrato da Bacia Sedimentar do Amazonas é composto por rochas granitognáissicas e vulcanosedimentares da Província Amazônia Central (CORDANI et al., 1984; TASSINARI et al., 2000) sotopostos por depósitos tafrogênicos das formações Prosperança e Acari, ambas do Grupo Purus.

A história deposicional da Bacia do Amazonas inicia-se no Neo-Ordoviciano com a sedimentação glacial a marinha rasa do Grupo Trombetas, cujas ingressões ocorrem de leste para oeste, tendo o Arco de Purus a função de barreira junto às bacias Solimões e Alto Tapajós. Reúne as formações Autás-Mirim (arenitos e folhelhos neríticos), Nhamundá (arenitos neríticos e depósitos glaciogênicos), Pitinga (folhelhos e diamictitos marinhos) e Manacapuru (arenitos e pelitos neríticos e litorâneos). Um novo ciclo transgressivo-regressivo ao longo do Devoniano-Carbonífero Inferior efetivou a deposição dos grupos Urupadi e Curuá, cujo estágio também levou ao desenvolvimento de sedimentação marinha e incursões glaciais. O Grupo Urupadi reúne as formações Maecuru (arenitos e pelitos neríticos e deltaicos) e Ererê (siltitos, folhelhos e arenitos neríticos e deltaicos). O Grupo Curuá agrega as formações Barreirinha (folhelho marinho), Curiri (diamictitos, folhelhos e siltitos glaciais), Oriximiná (arenitos e pelitos fluviais regressivos) e Faro (arenitos fluvio-deltáicos com influência de tempestades). Novo ciclo deposicional transgressivo-regressivo ocorreu na sinéclise Amazonas, entre o Neo-Carbonífero e Neo-Permiano, compreendendo a sedimentação continental e marinha do Grupo Tapajós associada a drásticas mudanças climáticas de frio para quente e árido. O grupo compreende as formações Monte Alegre (arenitos eólicos e wadis intercalados com siltitos e folhelhos de interdunas e lagos), Itaituba, Nova Olinda (calcários de inframaré e evaporitos de planície de sabkha) e Andirá (arenitos e folhelhos continentais e final do ciclo transgressivo-regressivo paleozoico). Este foi fortemente influenciado pela Orogenia Gonduanide propiciando soerguimento generalizado e 
extenso processo erosivo que pode ter removido cerca de 1000 metros de sedimentos da Formação Andirá (CPRM, 2006, p. 24) (Figura 7).

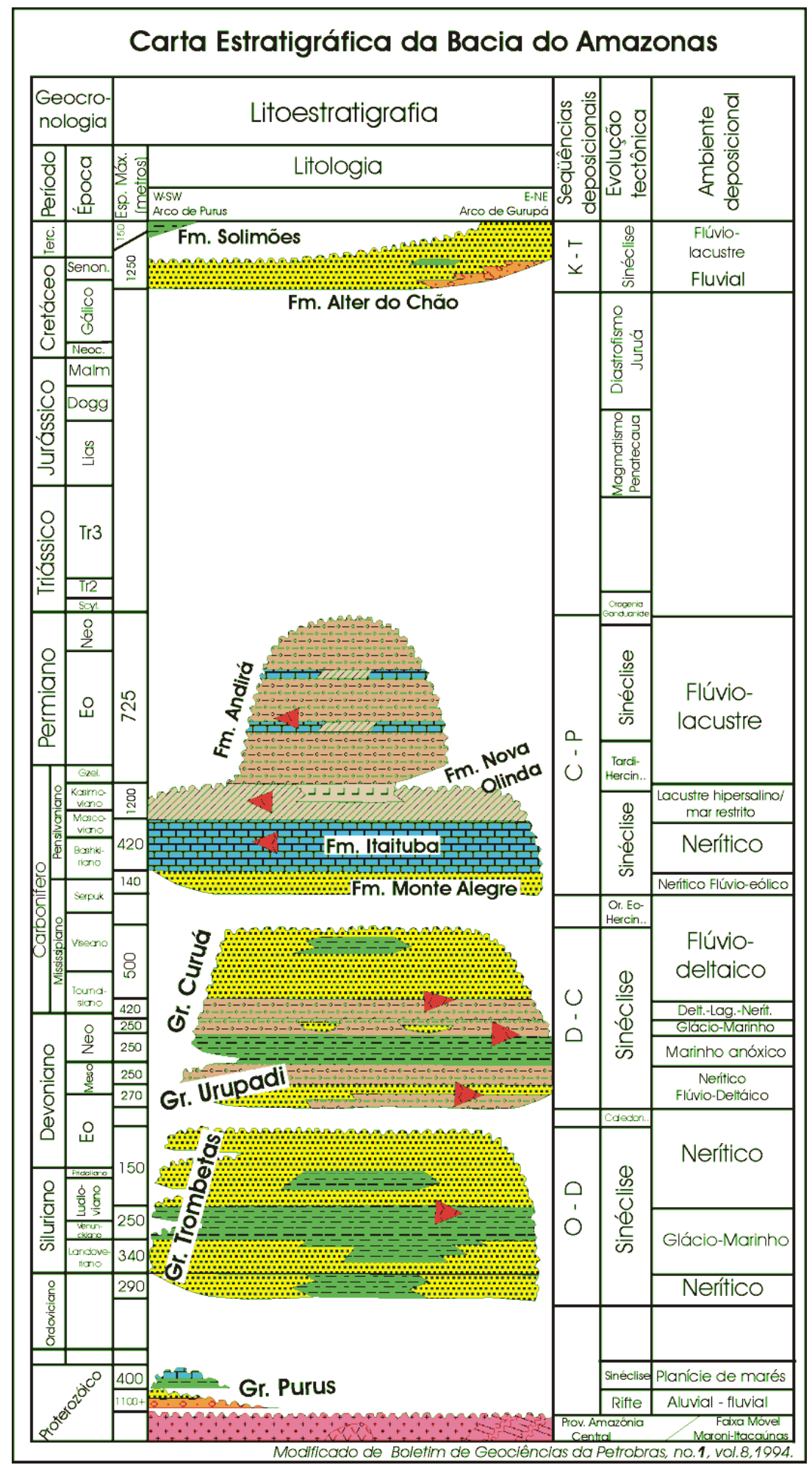

Figura 7: Coluna Estratigráfica da Bacia do Amazonas

Fonte: Cunha et al., 1994 
No Jurássico, um evento distensional de direção E-W afetou a bacia, permitindo a intrusão de soleiras de diabásio e enxame de diques de variada direção. O Diastrofismo Juruá, reflexo da abertura do Oceano Atlântico e soerguimento andino, precedeu o evento magmático e efetivou a reativação de falhas e fraturas, conferindo às rochas uma incipiente deformação oriunda de esforços compressionais com principal direção ENE-WSW.

A Sequência Cretácea-Paleógena resulta do relaxamento dos esforços compressionais, propiciando sítios deposicionais à sedimentação de clásticos continentais do Grupo Javari. Formaram-se sistemas fluviais fluindo em direção ao Oceano Pacífico, com deposição de grande volume de sedimentos arenosos da Formação Alter do Chão. No Paleógeno, o início do soerguimento andino causou o isolamento da bacia Alter do Chão, cujos rios cederam lugar a lagos extensos, alimentados por um sistema fluvial meandrante de baixa energia. A partir do Mioceno e paroxismo andino, foram depositados em ambiente flúvio-lacustre, sedimentos argilosos, sílticos e arenosos com níveis delgados de linhito e conchas de moluscos e cordatos da Formação Solimões (CAPUTO; RODRIGUES; VASCONCELOS, 1971; MAIA et al.,1977).

A estratigrafia da Bacia do Amazonas foi agrupada em quatro sequências deposicionais: três supersequências paleozoicas cobertas por uma sequência clástica continental do Cretáceo ao Recente, além de rochas intrusivas-soleiras e diques de diabásio do Mesozoico. Essas sequências estão separadas por discordâncias regionais associadas a episódios orogênicos cíclicos que afetaram toda a porção setentrional da Plataforma SulAmericana e adjacências (CUNHA et al., 1994; NEVES, 1990).

Segundo Cunha et al. (1994) a Sequência Ordoviciana-devoniana reúne os clásticos marinhos do Grupo Trombetas e está parcialmente truncada pela discordância decorrente da orogenia Caledoniana. A Sequência Devoniano-carbonífera corresponde aos clásticos flúviodeltáicos e neríticos dos grupos Urupadi e Curuá, e tem seu topo marcado pela discordância relacionada à orogenia Eoherciniana. A Sequência Permo-carbonífera é formada pelos clásticos, carbonatos e evaporitos continentais e de ambiente marinho restrito do Grupo Tapajós e está profundamente cortada pela discordância resultante da orogenia Gonduanide e do diastrofismo do Juruá. A Sequência Cretácea-terciária composta pelos clásticos flúviolacustres do Grupo Javari, ocupou os espaços criados pela atividade de orogenia Andina. 
Após a deposição destas sequências sedimentares, ocorreu na Bacia do Amazonas um evento distensivo em associação de intrusão de magmatismo básico (soleiras e diques com orientação na direção norte-sul).

$\mathrm{Na}$ região do arquipélago de Anavilhanas afloram representantes das seguintes sequências deposicionais: Sequência Ordoviciana-devoniana representada pelo Grupo Trombetas com ocorrências no limite norte da área de estudo; Sequência Cretácia-terciária representada pelo Grupo Javari (Figura 8).

O Grupo Trombetas foi definido como grupo por Caputo et al. (1971) e Caputo (1984) que subdividiu o mesmo, da base para o topo, nas formações Autás-Mirim, Nhamundá, Pitinga e Manacapuru. Baseando-se na análise bioestratigráfica de quitinozoários (GRANH, 1991; GRAHN; PARIS, 1992; QUADROS; MELO; GRAHN, 1990), Cunha et al. (1994), revelaram para o grupo uma idade ordoviciana-devoniana.

A Formação Autás-Mirim constitui a unidade basal do grupo, estando representada pela intercalação de arenitos, siltitos e folhelhos (ritmitos) não aflorantes na Bacia do Amazonas (CAPUTO, 1984). Subjacente à Formação Nhamundá, representa uma sequência deposicional de caráter regressivo, interpretada sob condições deposicionais flúvio-estaurinas e de praia, com intensa atuação eólica. A idade neo-ordoviciana foi postulada para a formação com base na identificação de fauna de quitinozoários (GRAHN, 1991; GRAHN; PARIS, 1992; QUADROS; MELO; GRAHN, 1990).

A Formação Nhamundá tem sua representatividade na porção oeste da faixa sedimentar paleozóica que constitui a borda norte da Bacia do Amazonas. Está constituída por arenitos finos a médios, com subordinada intercalação de folhelho, siltito e diamictito na proximidade do topo da seção. O ambiente de sedimentação é fluvial e litorâneo sob condições glaciais (CAPUTO, 1992; CAPUTO; CROWELL, 1985; CAPUTO; SAD, 1974; GRAHN, 1991; GRAHN; PARIS, 1992). É posicionada temporalmente no Eo-Siluriano, entre os andares Landoveriano e Eowenlockiano (GRAHN, 1991, 1992; GRAHN; PARIS, 1992). 


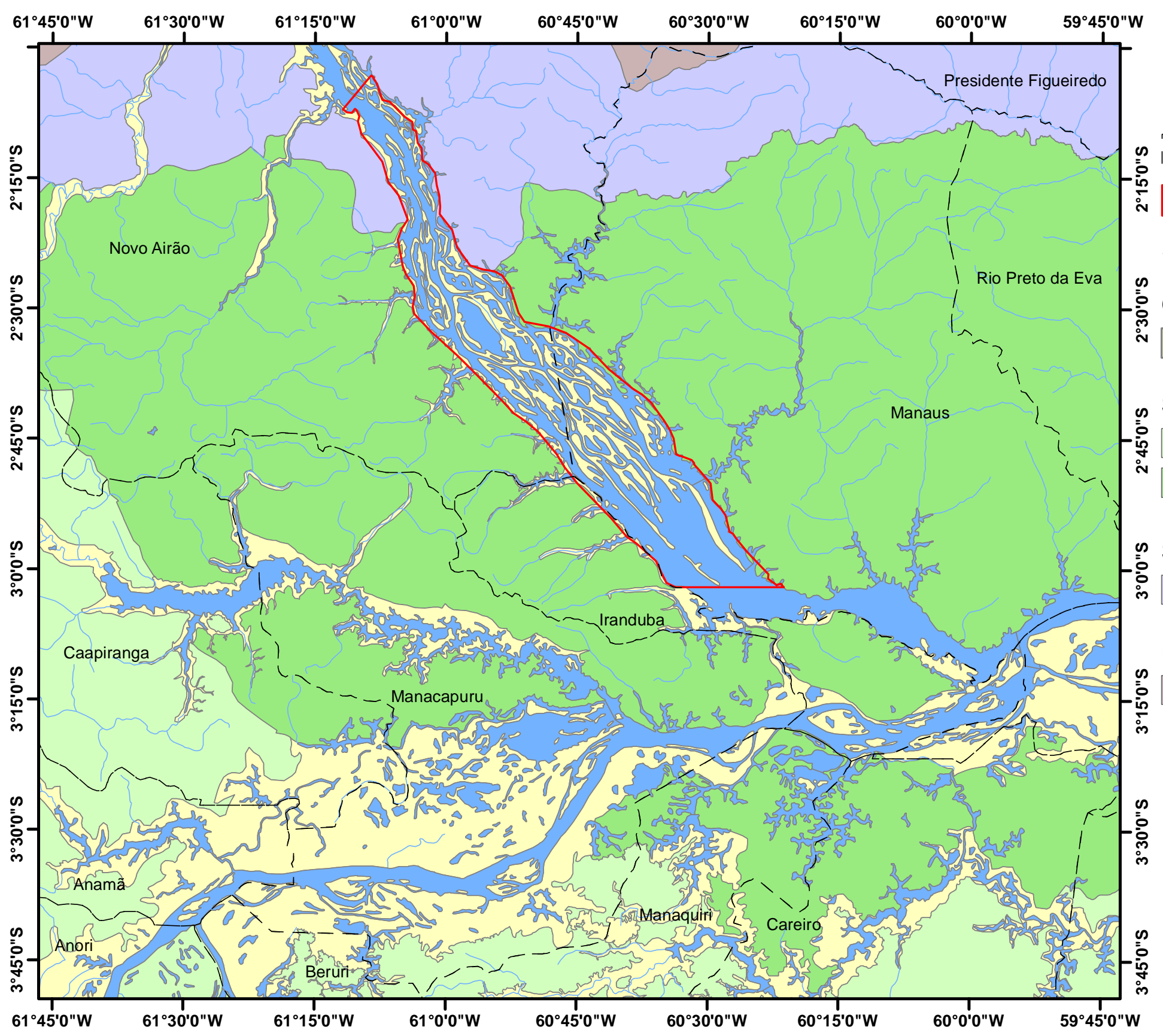

\section{GEOLOGIA}

\section{LEGENDA}

Limites Municipais

Área de Estudo Hidrografia

\section{QUATERNÁRIO}

$\square$ Depósitos aluvionares

SEQUÊNCIA CRETÁCEA-TERCIÁRIA

Wm. Içá

Fm. Alter do Chão

SEQUÊNCIA ORDOVICIANA-DEVONIANA

G GRUPO TROMBETAS

\section{PROTEROZÓICO}

GRUPO PURUS - Fm. Prosperança

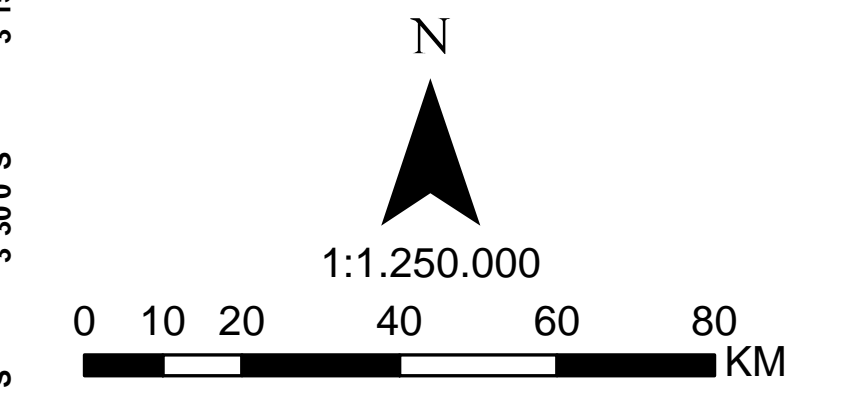

$61^{\circ} 45^{\circ} 0^{\circ} \mathrm{W} \quad 61^{\circ} 30^{\circ} 0^{\circ} \mathrm{W} \quad 61^{\circ} 15^{\circ} \mathrm{o}^{\circ} \mathrm{W}$
Figura 8: Mapa Geológico Regional

Datum SAD 69

Coordenadas LAT/LONG CPRM (2008) 
A Formação Pitinga (LANGE, 1967) é constituída por folhelhos, silexitos, arenitos e siltitos com leitos sideríticos. Mantém relações de contato concordante com a Formação Nhamundá, estratigraficamente sobrejacente. Sua idade eo-siluriana é baseada na ocorrência de graptólitos na borda sul da bacia (CAPUTO; ANDRADE, 1968).

A Formação Manacapuru constitui a unidade topo do Grupo Trombetas. De acordo com Cunha et al. (1994) reúne arenitos finos a médios intercalados com siltitos acinzentados e laminados, ocorrentes em todo o flanco norte da Bacia do Amazonas e rios Jarauaçu e Xingu no seu flanco sul. O ambiente de sedimentação é nerítico a litorâneo caracterizando uma sequência transgressiva-regressiva onde são identificados depósitos de praia e deltaico. A idade para esses sedimentos marinhos neríticos e litorâneos está no limite entre o NeoSiluriano ao Eodevoniano (Neoludloviano a Eolockoviano).

O Grupo Javari (EIRAS et al., 1994) reúne clásticos flúvio-lacustres que integram a Sequência Cretácea - Terciária cuja evolução encontra-se vinculada à atividade orogênica Andina. Reúne duas principais formações, Alter do Chão, neo-cretácea, e Solimões, depositada no período Mioceno-Plioceno. O grupo está presente nas bacias do Amazonas e Solimões.

A Formação Alter do Chão é a unidade de maior extensão aflorante na Bacia Sedimentar do Amazonas e está limitada pelos arcos de Purus a oeste e de Gurupá a leste, e é interpretada como produto de um sistema deposicional flúvio-deltáico-lacustre com planícies abandonadas de rios entrelaçados (CAPUTO; RODRIGUES; VASCONCELOS. 1972; CUNHA et al., 1994; DINO; SILVA; ABRAHÃO, 1999; KISTLER, 1954; NOGUEIRA et al., 2003; PEREIRA, 1988; SOUZA, 1974; VIERA; NOGUEIRA, 1998; WANDERLEY FILHO, 1991). Além dos arenitos e pelitos com intensa coloração vermelha, é composta de rochas siliciclásticas avermelhadas que incluem arenitos feldspáticos caulínicos, quartzoarenitos e quartzo-grauvacas com estratificação cruzada e intercalações de argilitos (incluindo caulins), siltitos e conglomerados, bem como brechas intraformacionais (CUNHA et al., 1994; KISTLER, 1954). A formação foi por muito tempo correlacionada às rochas sedimentares do Grupo Barreiras que aflora na região costeira do país, tendo sido posteriormente desvinculada a partir da identificação de dentes de dinossauro terópodo encontrado no poço 1-NO-1-AM (Nova Olinda) por Prince (1960), que forneceu seu 
estabelecimento ao Cretáceo Superior. A unidade apresenta uma morfologia tabular ou convexa. Em subsuperfície, a sucessão inferior é predominantemente arenosa e apresenta ciclos de ambientes fluviais anastomosados com retrabalhamento eólico. $\mathrm{Na}$ base ocorrem depósitos fluviais meandrantes onde aparecem depósitos residuais de canais e pelitos de preenchimento de meandro abandonado. A sucessão superior é predominantemente pelítica e de um ambiente progradacional flúvio-deltaico em ambiente lacustre (DINO; SILVA; ABRAHÃO, 1999).

Estudos micropaleontológicos estabeleceram uma idade cretácea Turoniana para a porção média (DAEMON; CONTRERAS, 1971; DAEMON, 1975). Travassos e Barbosa Filho (1990), baseados em palinomorfos, acreditam que a sedimentação da formação ocorreu entre o Cretáceo Superior e o Paleógeno. Dino et al. (1999) reafirmam que a associação palinológica observada para a formação permite o estabelecimento de sua deposição entre os andares Alagoas Superior e Cenomaniano.

A Formação Solimões, cujo termo foi revalidado por Caputo, Rodrigues e Vasconcelos (1971), agrupa argilitos avermelhados a acinzentados e níveis de arenitos conchíferos e de linhito, com ampla distribuição nas bacias do Solimões e do Acre. No topo da formação ocorre arenito branco, fino a grosso, com grãos angulosos e subarredondados. A unidade é rica em fósseis vegetais e vertebrados. Cruz (1984) estabeleceu três zonas palinológicas para a formação, correspondentes ao Mioceno, Mioceno-Plioceno e Plioceno. Segundo Caputo (1984) a Formação Solimões corresponde a uma sedimentação molássica distal, sendo a porção superior depositada em ambiente fluvial e lacustre. A formação recobre em discordância a Formação Alter do Chão e forma uma cunha sedimentar desde o Arco de Purus até as bacias subandinas, atingindo mais de 7.000 metros de espessura.

Os depósitos cenozoicos (terciário e quaternário) da área de estudo compreendem basicamente as coberturas modernas e os depósitos aluviais ao longo do sistema fluvial da região. São constituídos por sedimentos arenosos e argilosos depositados em um complexo sistema e formas fluviais, incluindo, diques marginais, depósitos de canais e de barras de meandros, barras ativas, depósitos de planície de inundação, depósito de rompimento de dique, terraços aluviais, depósitos em meandros abandonados e lagos. Ao longo de tributários 
dos principais rios da região desenvolvem-se sedimentos aluviais recentes compostos por areias, siltes e argilas (SILVA, 2005, p.46).

Franzinelli e Igreja (2002) descreveram, ao longo do Rio Negro, sedimentos arenosos finos situados em terraços na planície de inundação; areias quartzosas e também argila cinza e mosqueada em depósitos de canais, sedimentos siltosos nas barras das ilhas do Arquipélago de Anavilhanas, e frações argila, silte, enquanto nos igapós predominam raras areias finas e grande quantidade de matéria orgânica.

$\mathrm{Na}$ região são ainda descritas coberturas lateríticas desenvolvidas em ambiente de clima tropical durante o Cenozoico. As coberturas lateríticas na região amazônica desenvolveram-se em dois períodos bem distintos: o Terciário Inferior (Eoceno-Oligoceno) e Terciário Superior/Pleistoceno (COSTA, M. L. 1991). Os lateritos mais antigos, designados Lateritos Maturos, constituem-se em perfis bem evoluídos, profundos. Têm no topo horizonte ferruginoso, ferro-aluminoso, bauxítico ou bauxíticofosfático, que abriga a maioria dos depósitos de bauxita da região. A crosta ferruginosa ou ferro-aluminosa comporta-se como proteção parcial contra a erosão física e intemperismo químico e na paisagem regional geralmente sustentam superfícies planas elevadas de platôs tendo dezenas a vários milhares de metros de extensão e altitudes de 50 a 800 m. Essas superfícies podem estar recobertas por latossolos e sedimentos ou até mesmo terem suas crostas expostas, e sobre elas desenvolveuse floresta tropical ou paisagem de savana, respectivamente.

Os lateritos mais jovens, designados Lateritos Imaturos (COSTA, M. L. 1991), são de idade pós-Barreiras e pós-Solimões, e marcam-se por horizonte ferroalumino-argiloso. São pouco evoluídos, menos profundos e desprovidos de horizonte bauxítico ou bauxíticofosfático. Delineiam, onde não se depositou sedimentos quaternários, a paisagem de áreas topograficamente mais baixas dominantes na região amazônica.

Em relação à tectônica regional, Sternberg (1950) assinalou a presença de lineamentos que controlam parte da rede de drenagem atual da Amazônia, a incidência de terremotos em amplas áreas e o desenvolvimento de falésias sob controle de falhas nas margens dos principais rios. Desde então diversos estudos e trabalhos sobre diversos aspectos da região vem sendo publicados e demonstram que grande parte dos rios está condicionada às falhas geológicas modernas. 
Costa, J. B. S. et al. (2008) delinearam, com base em informações acumuladas ao longo dos últimos anos, que a evolução geológica da região Amazônica na sua etapa mais recente está vinculada à neotectônica e, segundo estes autores, isto evidencia-se nas estruturas, sequências sedimentares, padrões de rede de drenagem e sistemas de relevo na região.

Após a deposição das sequências sedimentares do Terciário Inferior na região Amazônica, (registro das últimas manifestações do Evento Sul-Atlantiano), desenvolveu-se um perfil laterítico maturo (Eoceno-Oligoceno) marcando importante período de estabilidade tectônica, seguido por processos de estruturação, morfogênese e sedimentação até hoje em vigor, relacionados com a incidência da Neotectônica, cujo regime tectônico é do tipo transcorrente. Dois pulsos de movimentação transcorrente são reconhecidos, um do MiocenoPlioceno e outro do Pleistoceno Superior-Recente, a eles se relacionando deslocamento ao longo de feixes de falhas, geração de depósitos sedimentares, controle de padrões de drenagem e de padrões de formas interfluviais (COSTA, J. B. S. et al., 2008, p.24)

Os denominados lateritos maturos (COSTA, M. L., 1991) do Terciário Inferior servem como referenciais na identificação de deslocamentos neotectônicos, manifestos em desníveis de platôs. Os lateritos mais jovens (imaturos), do Terciário Superior/Pleistoceno, também sofreram deformações ligadas a manifestações neotectônicas. A deformação destes lateritos indica que a neotectônica não atuou continuadamente na região Amazônica, mas em pulsos, com um primeiro pulso que incidiu logo após a formação dos lateritos maturos, provavelmente no Mioceno, e um segundo, que sobreveio após a instalação dos lateritos imaturos, ainda no Pleistoceno. Em adição, houve deformação de stone lines derivadas de perfis imaturos, que serve como indicador de que a neotectônica estendeu-se até o recente (COSTA, J. B. S. et al., 2008, p.25)

De acordo com Costa, J. B. S. et al. (2008), as estruturas neotectônicas da Região Amazônica, passaram a ser melhor entendidas a partir de investigações de campo, acompanhadas de análise sistemática de cartas plani-altimétricas e de diversos produtos de sensores remotos em diversas áreas-chave: (1) Nordeste de Roraima; (2) Centro-oeste do Amazonas; (3) Leste do Amazonas; (4) Oeste do Pará; (5) Centro-norte do Pará; (6) Leste do Amapá; (7) Nordeste do Pará; (8) Noroeste do Maranhão; (9) Sudeste do Pará e Oeste de Tocantins; (10) Nordeste de Tocantins/Sul do Maranhão, conforme figura 9. 


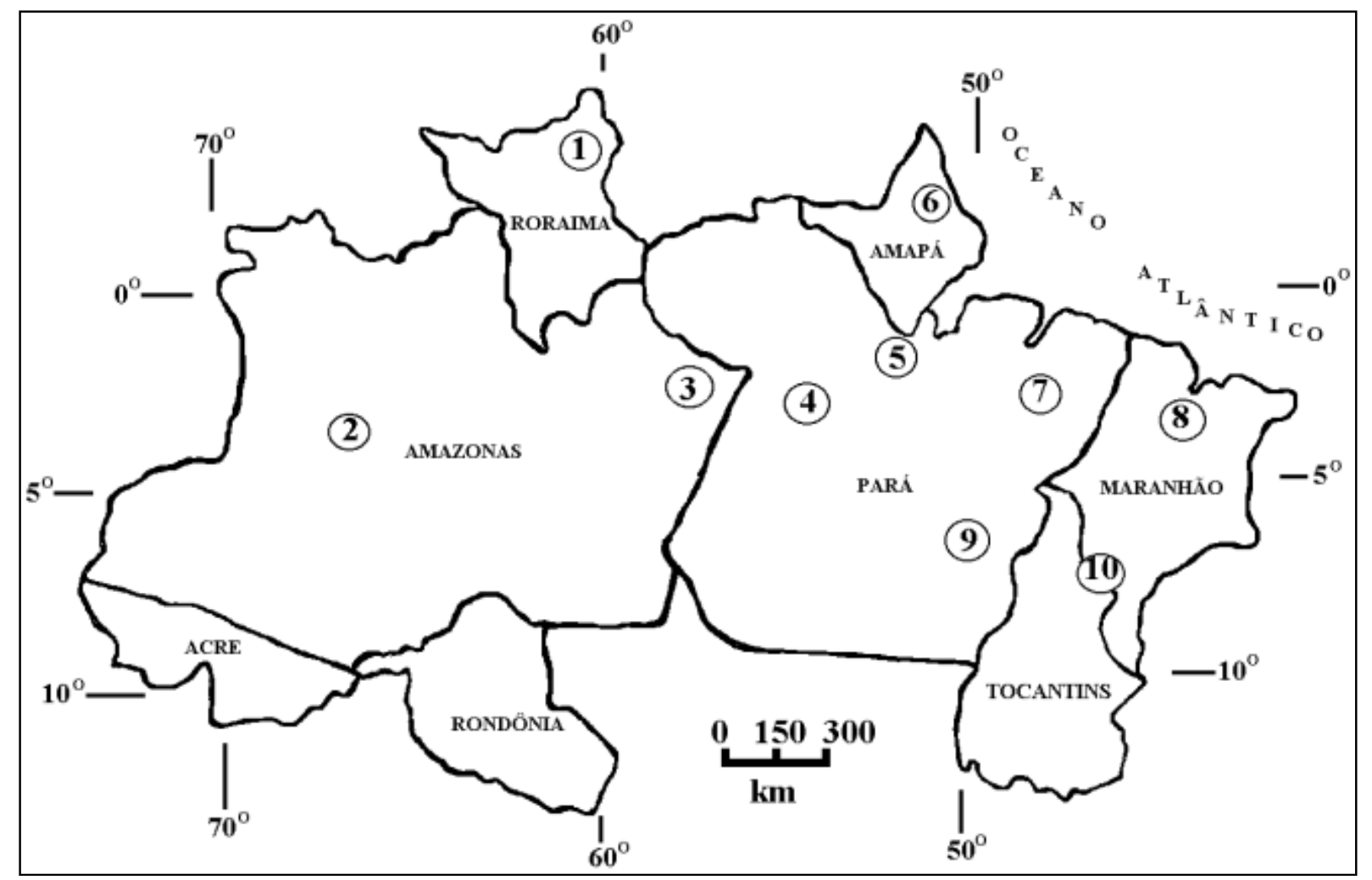

Figura 9: Localização das áreas-chave

Fonte: COSTA, J. B. S. et al., (2008)

A área de estudo encontra-se no domínio Centro-Oeste do Amazonas (2) que é caracterizado por extensas áreas de ocorrência de sequencias sedimentares do Terciário Superior e do Quaternário, além de áreas pré-cambrianas na porção do alto Rio Negro. Evidências de movimentos tectônicos positivos afetando as unidades cenozoicas, expressas por rios encaixados, migração de canais, terraços soerguidos e extensos segmentos de rios retilíneos, foram apontadas por Oliveira et al. (1977) e Franco e Moreira (1977) através de mapeamentos geomorfológicos. Com base na análise do sistema de drenagem, Costa, J. B. S. et al. (2008) reconheceram três compartimentos estruturais principais: a) O compartimento sul caracterizado por um padrão de drenagem paralelo formado por trechos dos rios Juruá e Purus, e seus afluentes, orientados preferencialmente na direção E-W; b) O compartimento central compreende a área situada entre as cidades de Benjamim Constante e o baixo curso do Rio Purus; c) O compartimento norte estende-se desde a Colômbia até os baixos cursos dos rios Negro e Solimões (Figura 10). 


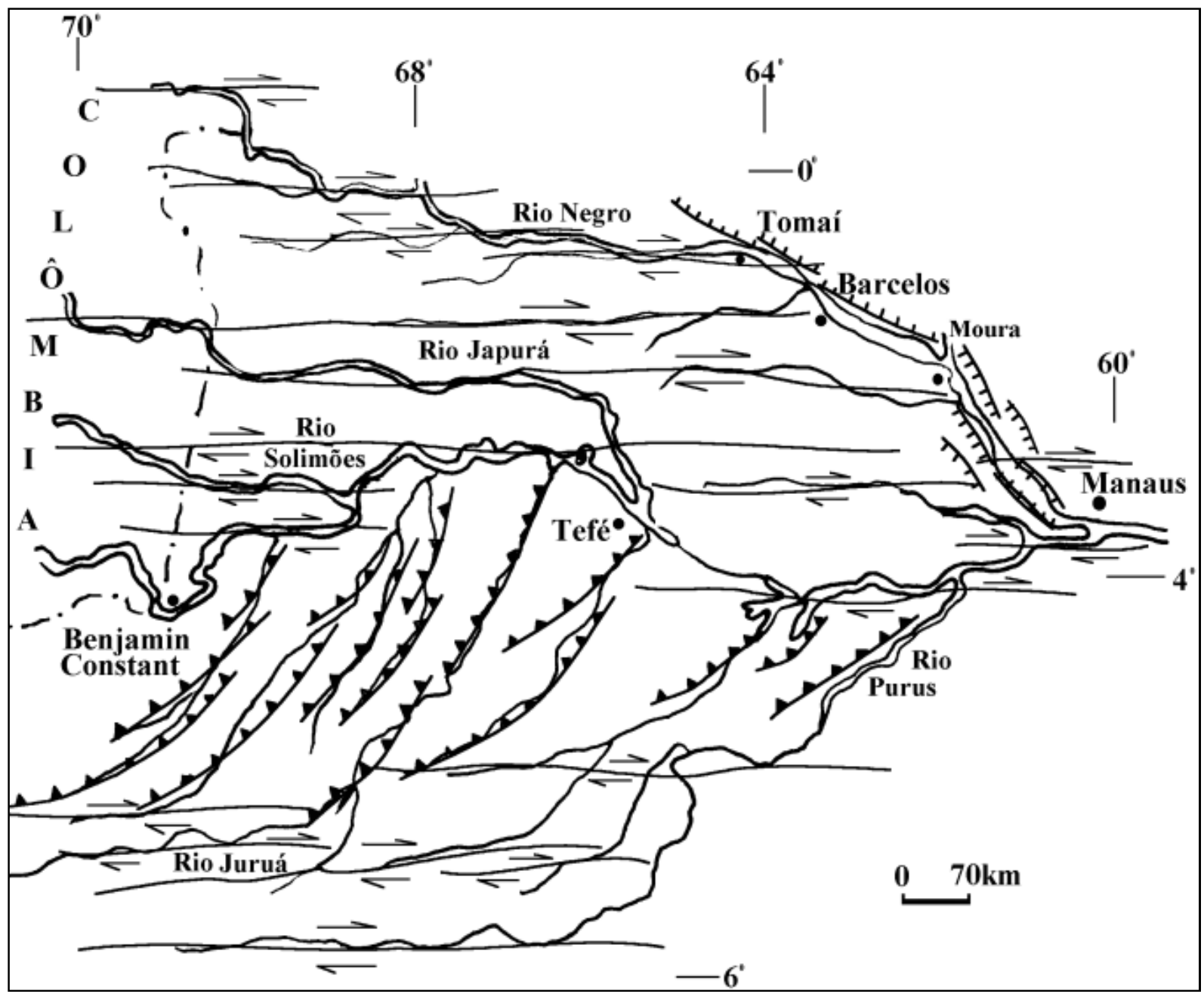

Figura 10: Principais estruturas neotectônicas da região centro-oeste do Amazonas.

Fonte: COSTA, J. B. S. et al. (2008)

Nota: nesta figura as falhas transcorrentes são indicadas por linhas com ou sem par de setas, estas apontando o movimento relativo; as falhas normais são indicadas por linhas com pequenos traços perpendiculares e as falhas inversas ou de cavalgamento são mostradas por linhas denteadas.

O compartimento norte, onde se insere a área de estudo, é definido por um padrão de drenagem retangular angulado e controlado principalmente por lineamentos de direções E-W e NE-SW. Os lineamentos E-W são os mais importantes e muitos deles se interligam através dos lineamentos NE-SW. Esses lineamentos E-W são interpretados como falhas transcorrentes dextrais e os NE-SW, como falhas inversas, cujas articulações demarcam extensas estruturas romboédricas transpressivas. No extremo nordeste dessa área, na região do baixo Rio Negro, a estruturação é definida principalmente por falhas normais de direção NWSE interagindo com falhas maiores E-W, transcorrentes dextrais, resultando no desenvolvimento de várias bacias romboédricas transtensivas. A bacia mais importante situase na região de confluência dos rios Negro e Branco e aloja uma extensa sequencia sedimentar atribuída ao Quaternário. As falhas-mestras normais dessa bacia mergulham para 
nordeste e controlam a orientação geral do Rio Negro no alinhamento das cidades de Moura e Barcelos.

O rio Negro corre em uma zona de falha normal, que se estende por cerca de $70 \mathrm{~km}$ em linha reta, controlando ambas as margens. Essa estrutura geológica forma grábens (áreas em depressão), que são locais propícios à sedimentação atual. $\mathrm{O}$ "arquipélago das Anavilhanas" e os depósitos Cacau-Pirêra, estes próximos a Manaus, são resultantes da interrelação entre processos de sedimentação e fenômenos tectônicos (SILVA, 2005).

A falha do rio do Negro é uma estrutura importante mencionada por diversos autores, incluindo Sternberg (1950), Andrade e Cunha (1971), RADAMBRASIL (1978) e Franzinelli e Igreja (1990; 2002). Esta falha, com direção preferencial NW-SE, controla as margens desse rio e se reconhece facilmente em mapas e em imagens de satélite por meio da retilinidade do rio e de suas escarpas em ambas as margens do rio. De acordo com Cordani et al. (1984), a falha do rio do Negro é uma extensão possível das estruturas do Cráton Amazônico, sugerindo que estas foram reativadas durante o Paleozoico e Cenozoico.

Ao lado das evidências de tectônica no rio Negro, aliam-se outras, como a presença de foz afogada em quase todos os afluentes do rio Negro, configurando rias fluviais. Elas ocorrem nas duas margens do rio Negro e são mais frequentes no arquipélago das Anavilhanas onde o rio apresenta padrão anastomosado. $\mathrm{O}$ aparecimento de rias originadas por tectônica nas duas margens do rio Negro, o nível de terraço, os falhamentos direcionando o curso e a assimetria da bacia em relação à do Solimões são evidências de que este rio foi submetido, em determinados, trechos a controles tectônicos ${ }^{3}$. O escarpamento de suas margens associada à falhamentos, a largura do rio nos trechos anastomosados e o afogamento da foz de seus afluentes sugerem, uma adaptação do rio Negro à estrutura do tipo rift-valley (RADAMBRASIL, 1978).

Os estudos têm mostrado que a atuação das falhas geológicas causa significativas mudanças na paisagem amazônica, inclusive influenciando a dinâmica fluvial dos rios

\footnotetext{
${ }^{3}$ Aqui considera-se que os fatores climáticos também colaboram para a explicação de determinadas morfologias fluviais.
} 
amazônicos. Mega migrações do rio Solimões, surgimento e o desaparecimento de bancos de areia, a erosão de margens (fenômeno de terras caídas), e o abandono de leito são, muitas vezes, consequência indireta de processos tectônicos (SILVA; ROSSETTI, 2009, p.24).

Segundo Silva et al. (2007), o encontro das águas, entre os rios Negro e Solimões, estivera cerca de $50 \mathrm{~km}$ à jusante da atual posição. Após o preenchimento sedimentar nessa área de confluência fluvial, o rio Negro teve seu desvio, em direção à Manaus, motivado por zonas de fraquezas leste-oeste.

Almeida Filho, Miranda e Beisl (2005), por meio de dados de elevação digital do terreno obtidos pela Shuttle Radar Topographic Mission (SRTM), encontraram sinais de um provável paleocurso do baixo Rio Negro. Para esses autores é possível inferir, pelo seu traçado, que a confluência dos rios Negro e Solimões localizava-se onde hoje fica a desembocadura do Rio Manacapuru, a cerca de $70 \mathrm{~km}$ a oeste da cidade de Manaus, análise que sugere que o traçado atual do Rio Negro na região de Anavilhanas resultaria de uma mega captura fluvial, por efeito de uma neotectônica ativa na região, cujo trabalho é corroborado por Silva e Rossetti (2009).

Ao estudar a região do Baixo rio Negro, utilizando como recurso o sensoriamento remoto, Franzinelli e Igreja (1990) indicaram que a configuração tectônica da região revela um modelo neotectônico de meio-graben com eixo de estiramento máximo na direção N50$55 \mathrm{E}$, porém dados estruturais, sedimentológicos e ambientais, convergem para um sistema direcional dextral divergente com a direção geral de transcorrência para S80-90E, e o eixo de compressão máxima aproximadamente na direção S30E, cujo modelo é coerente com as feições hidrográficas, geomorfológicas e sedimentológicas da área e encaixa-se perfeitamente no modelo tectônico regional. O conjunto de feições compreende falhas normais NW-SE, representadas pela orientação dos rios Baleteiro, Tucumã, Coanã e Negro, e falhas de transferência NE-SW, destacadas pelos alinhamentos dos rios Apuaú e Cuieiras (Figura 11).

A região do Baixo rio Negro é, portanto, controlada em grande parte por um lineamento tectônico de direção NW-SE, que é um segmento de um maior megasistema transcorrente dextral da tectônica da bacia Amazônica. Franzinelli e Igreja (2002) afirmam que a neotectônica nesta área é responsável pela profundidade do rio e a ocorrência de falésias em suas margens, e que esta neotectônica influenciou na origem das ilhas de Anavilhanas e dos igapós, localizados entre os blocos altos da "terra firme" e os blocos rebaixados do canal. 
De acordo com Latrubesse e Franzinelli (2005), o traçado do rio Negro mostra forte controle estrutural. Neste trabalho os autores dividem o curso do rio em seis trechos com base no estilo geomorfológico e controle estrutural. Os trechos I e II (Alto rio Negro) têm como principal feição fraturas de direção aproximada N-S e E-W; Os trechos III e IV (Arquipélago de Mariuá e trecho após a confluência com o Rio Branco, respectivamente) têm seu vale principal controlado por uma grande falha; Nos trechos V e VI (Arquipélago de Anavilhanas e Baixo rio Negro) a margem direita do rio é controlada por uma grande falha de direção geral NW que continua até a longitude de $61^{\circ} 38^{\prime}$. Esta controla o trecho inferior dos afluentes da margem direita tais como dos rios Unini, Jaú e Carabinani. 


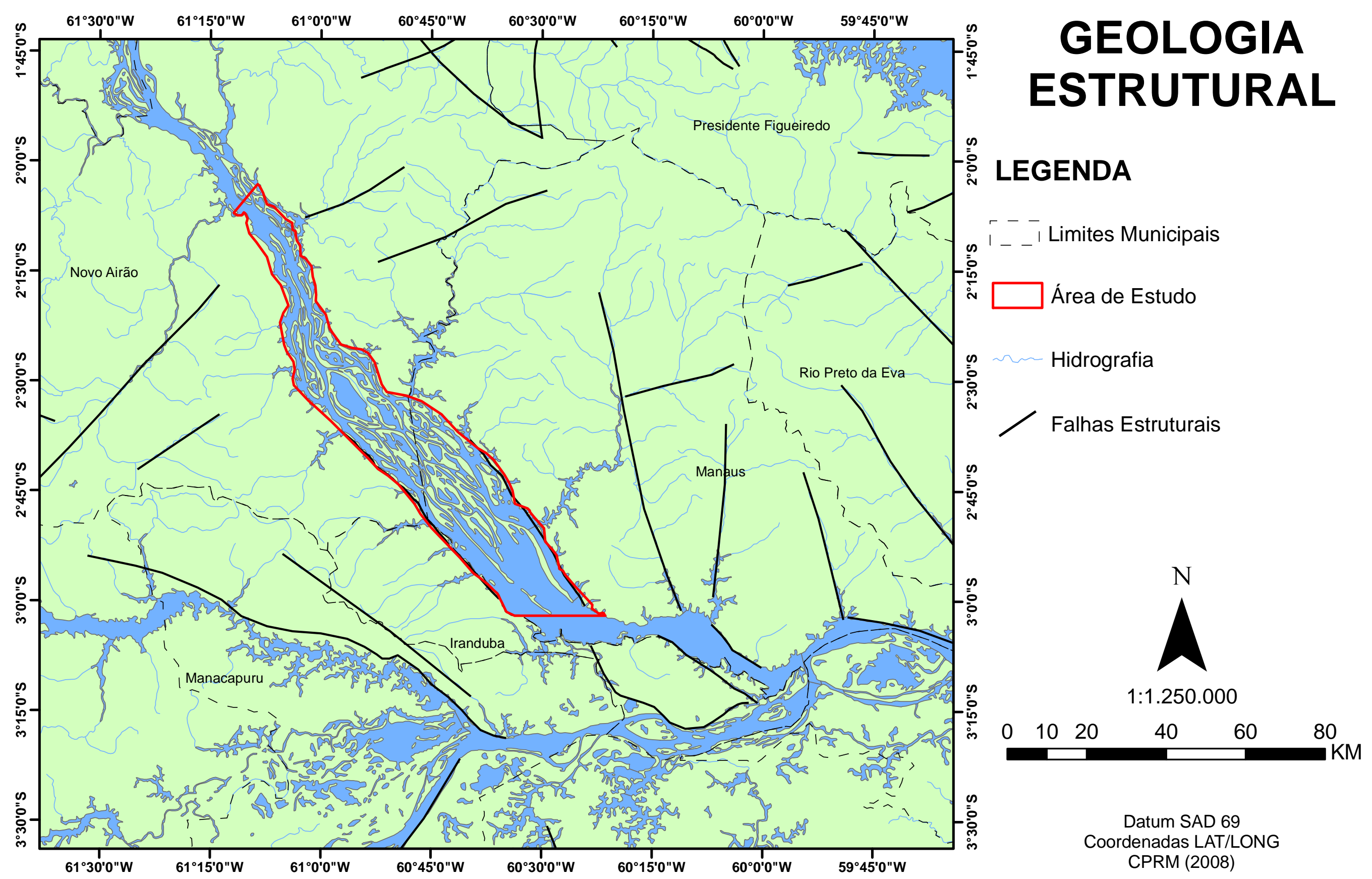

Figura 11: Principais lineamentos estruturais do baixo Rio Negro (adaptado de FRANZINELLI e IGREJA, 1990) 


\subsection{GEOMORFOLOGIA}

A área de estudo, Arquipélago de Anavilhanas, foi estudada por Paiva (1929) que, subindo o rio Negro, descreveu a faixa anastomosada à montante da cidade de Manaus, referindo-se a ela da seguinte forma: "o arquipélago do baixo curso do rio Negro possui forma labiríntica, dada a disposição entre o comprimento e a largura das ilhas”. Descreveu os depósitos praiais como "restingas" de 100 a 200 m de largura, formados pelo "trabalho da corrente fluvial". Ainda que esta seja uma expressão vaga, provavelmente está se referindo às barras laterais. De acordo com o autor são praias evoluídas onde a vegetação se instalou mantendo-as e fixando-as, efetuando uma colmatagem localizada.

Sakamoto (1957) referiu-se a esse trecho do rio como um alargamento grande de seu canal, sendo possível a existência de um "vale" submerso.

Tricart (1977a) tratou dos trechos anastomosados do rio Negro como expansões lacustres colmatadas, evidenciando tectônica.

Sternberg (1950), observando o padrão acentuadamente ortogonal frequentemente notado na rede de drenagem da Amazônia, com direções preferenciais NW-SE e NE-SW, interpretou-o como resultante de uma ação tectônica. $\mathrm{O}$ autor mostrou as evidências tectônicas no controle da rede de drenagem, também através do paralelismo existente entre os rios Negro e Urubu.

Tricart (1977a), interpretando imagens de radar, confirmou alguns eventos levantados por Sternberg, sugerindo efeitos tectônicos em certos trechos do rio Negro e Solimões, com consequente deslocamento destes rios, adaptando-se a ângulos de falhas com direções NW-SE e SW-NE, a exemplo do curso inferior do rio Negro.

Santos et al. (1974) dividiram as Formações Solimões e Alter do Chão, utilizando padrões de formas ocorrentes na zona de contato entre ambas, como um dos critérios para esta divisão. Distinguiram dois padrões de formas: um correspondente à área da Formação Solimões: "planície de dissecação e subsidência, relevo plano e vales em V" e outro referente 
à área da Formação Alter do Chão: "planície de dissecação com drenagem dendrítica relativamente densa, com vales em $\mathrm{V}$ e modelado plano-ondulado e tabular".

O projeto RADAMBRASIL (1978) agrupou na folha SA-20 Manaus, por meio da interpretação geomorfológica dos mosaicos de radar na escala 1:250.000, usando como critério a homogeneidade das formas de relevo e seu posicionamento altimétrico relativo, as diversas manchas mapeadas em sete compartimentos denominados unidades morfoestruturais: Planície Amazônica, Pediplano Rio Branco-Rio Negro, Depressão Periférica do Norte do Pará, Planalto Rebaixado da Amazônia Ocidental, Planalto Dissecado Rio Trombetas-Rio Negro, Planalto da Bacia Sedimentar do Amazonas e Planalto Dissecado Norte da Amazônia. Estas unidades foram reclassificadas no Mapa Geomorfológico do Amazonas do IBGE (2010) nas seguintes unidades geomorfológicas: Planície Amazônica, Depressão Rio Branco-Rio Negro, Depressão Periférica da Amazônia Setentrional, Depressão do Negro-Japurá, Planalto do Uatumã-Jari, Planalto Setentrional da Bacia Sedimentar do Amazonas e Planalto Dissecado do Norte da Amazônia, respectivamente.

A região do baixo rio Negro faz parte do Planalto Dissecado Rio Trombetas-Rio Negro (NASCIMENTO, D. A. et al., 1976), de idade neo-pleistocênica, reclassificado pelo IBGE (2010) como Planalto do Uatumã-Jari. O relevo, composto por interflúvios tabulares e colinas foi modelado nos depósitos da Formação Alter do Chão e possui altitudes em torno de 150 metros. No seu baixo curso, o rio Negro secciona o Planalto do Uatumã-Jari, destacandose como principal agente da drenagem. Fluindo na direção geral NW-SE recebe alguns de seus tributários nesse trecho, que apresentam um padrão dendrítico de drenagem. Os tributários da margem esquerda compreendem, neste trecho, os rios Baependi, Apuaú, Cuieiras, e os igarapés Tarumã-Mirim e Tarumã-Açu, cujas cabeceiras estão no Planalto Setentrional da Bacia Sedimentar do Amazonas ou próximo a ele (Figura 12). Possui direção geral N-NE/S-SW, desembocam no rio Negro, apresentando foz afogada que configura lagos ${ }^{4}$ alongados e pouco recortados. Os afluentes da margem direita nascem no próprio planalto Planalto do Uatumã-Jari, enquanto os mais extensos a oeste nascem na Depressão do NegroJapurá. Destacam-se os rios Carabinari, Puduari e os igarapés Freguesia, Açu e Tumbira.

\footnotetext{
${ }^{4}$ Neste estudo evita-se a denominação de lagos para as rias
} 
Estes rios seguem direção geral SW-NE, com padrão dendrítico de drenagem e também tem suas desembocaduras afogadas formando lagos. De maneira geral apresentam percurso reduzido, correndo em vales encaixados, controlados por alinhamento estrutural, sem deixar extensas faixas de planície.

O rio Negro, no trecho que secciona o Planalto do Uatumã-Jari, apresenta margens escarpadas, as denominadas "falésias fluviais". Apenas em alguns trechos de sua margem esquerda há áreas de acumulação, mapeadas como planície aluvial. Neste trecho apresenta padrão anastomosado formando um emaranhado de ilhas, lagos que, segundo o (RADAMBRASIL, 1978) seria resultado da deposição alternada de sedimentos. Essas ilhas são cortadas por um sistema de paranás que isolam ilhas menores dentro do conjunto conhecido como Arquipélago de Anavilhanas. Neste trecho as ilhas ocorrem em menor quantidade que no Arquipélago de Mariuá a montante e possuem grandes lagos em seu interior, restringindo a sua superfície emersa.

Em direção a Manaus, na parte terminal do trecho anastomosado de Anavilhanas, as ilhas se dispõem em forma de "cauda de cometa" apresentando formas alongadas e estreitas como pode ser observado na figura 10. Após este trecho, o rio volta a ter canal único, até a sua confluência com o rio Solimões. Neste trecho o rio não mais apresenta ilhas mas apenas margens escarpadas do tipo falésia fluvial, originando desníveis de 5 a 10 metros, nitidamente identificados nas proximidades de Manaus. 


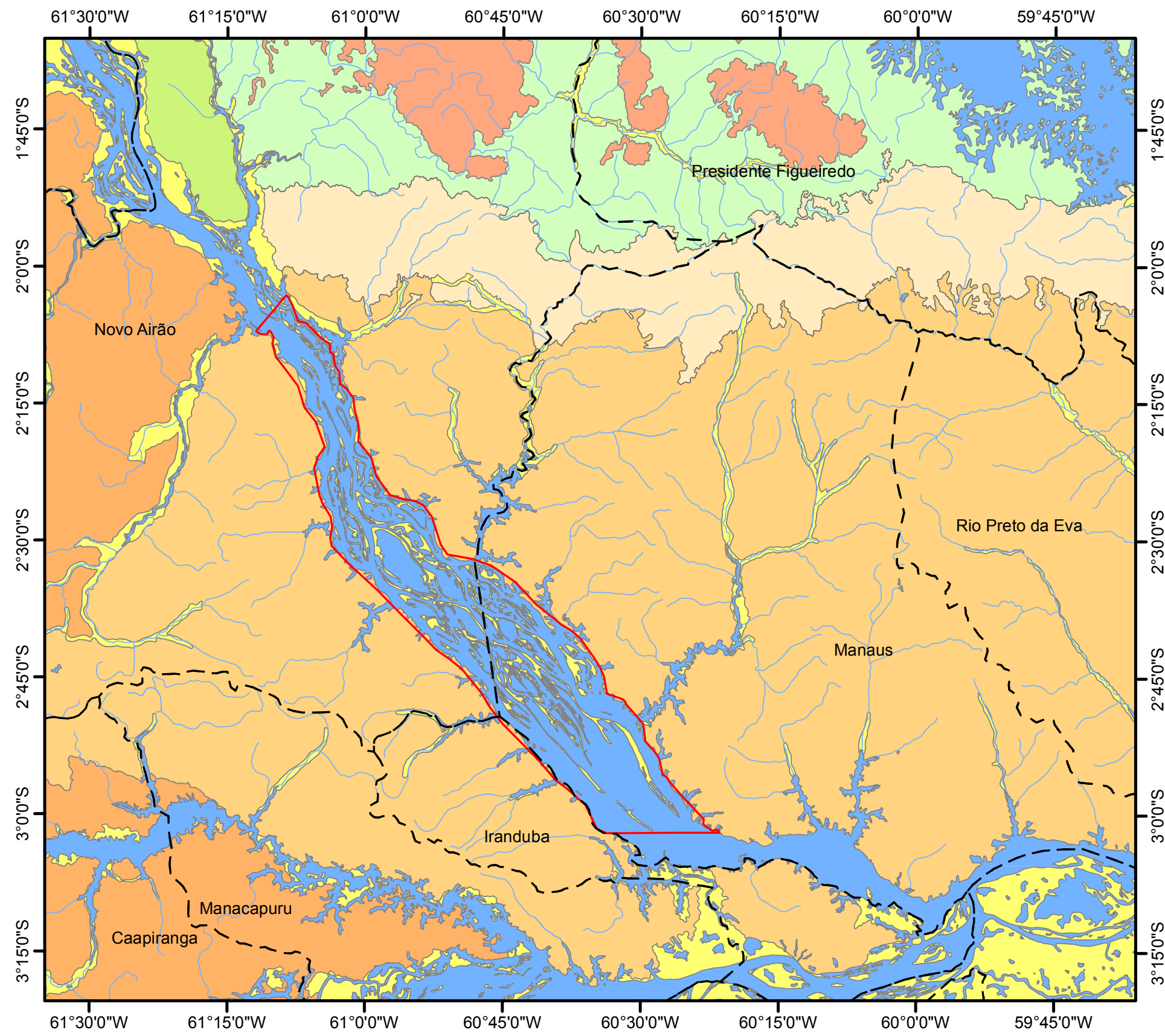

\section{GEOMORFOLOGIA}

\section{LEGENDA}

$r-{ }_{I}$ Limites Municipais

L - -

Área de Estudo

थ Hidrografia

\section{UNIDADES GEOMORFOLÓGICAS}

Depressão Periférica da

Amazônia Setentrional

Depressão do Rio Branco -

Rio Negro

Planície Amazônica

Planalto Dissecado do

Norte da Amazônia

Planalto do Uatumã - Jari

Planalto Setentrional da

Bacia Sedimentar do Amazonas

Depressão do Negro - Japurá

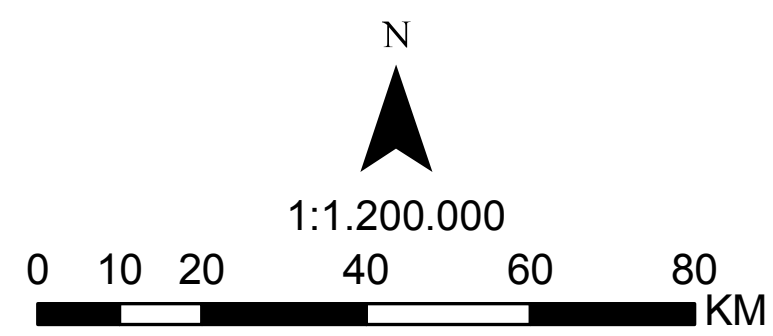

Datum SAD 69 Coordenadas LAT/LONG IBGE (2010)

Figura 12: Unidades Geomorfológicas 


\subsection{PEDOLOGIA}

A Amazônia Central, na região próxima ao Rio Solimões, apresenta duas ordens de paisagem inteiramente diferentes: as várzeas e as terras firmes. Nas várzeas predominam solos mais jovens, formados a partir de sedimentos quaternários, e, em alguns casos, apenas sedimentos em processo incipiente de pedogênese. Na terra firme, em geral, os solos são mais evoluídos, formados a partir de sedimentos ou rochas do terciário ou ainda mais antigos.

Os solos de terra firme, geralmente cobertos por uma densa floresta, apresentam boas características físicas, mas geralmente têm baixa fertilidade química natural, por serem solos bastantes intemperizados e lixiviados (SIOLI, 1991). O empobrecimento desses solos se dá principalmente em função da perda de matéria orgânica destas áreas devido às derrubadas, queimadas e introdução de culturas anuais e pastagens (FEARNSIDE, 1996).

Os principais solos da região Amazônia são os Latossolos distróficos, que ocupam aproximadamente 40\% da Amazônia e os Argissolos distróficos com 29\%, seguidos de Plintossolos com 7,5\% (IBGE, 2001).

Para a região do baixo curso do rio Negro, na área do Arquipélago de Anavilhanas, o projeto RADAMBRASIL (1978) descreve o desenvolvimento de Latossolos Amarelos álicos sobre os sedimentos da Formação Alter do Chão, em relevo suave ondulado a forte ondulado, com textura desde média a muito argilosa, sob vegetação de densa floresta. Nas áreas mais acidentadas são marcados a ocorrência de solos Concressionários Lateríticos distróficos com B textural e os Podzólicos Vermelho Amarelos álicos concressionários. De acordo com os autores, estes solos estiveram provavelmente sob a influência de um clima com prolongados períodos secos, justificando, desta forma, a presença de concreções lateríticas. Para as áreas de ocorrência dos sedimentos recentes não consolidados, referentes ao quaternário, os solos destacados incluem os podzóis hidromórficos, solos hidromórficos gleizados, solos aluviais e as areias quartzosas hidromórficas.

O Mapa Exploratório de Solos do Estado do Amazonas, na escala de 1:1.800.000, elaborado pelo Instituto Brasileiro de Geografia e Estatística - IBGE (2010) descreve, para a mesma região, o predomínio de Latossolo Amarelo ácrico típico (LAw9) na área de ocorrência dos sedimentos da Formação Alter do Chão, ou seja, na Terra Firme ou no modelado tabular. O Latossolo Amarelo ácrico típico (Law9) apresenta-se com textura 
argilosa, com relevo suave ondulado e associadamente, ocorrem Latossolos Amarelo distrófico (Lad), Plintossolo Pétrico concressionário(FFc) e Argissolo Amarelo distrófico (PAd). Para as ilhas de Anavilhanas é descrito o predomínio de Gleissolos Háplicos Tb distróficos típico e neossólico (GXbd10) apresentando textura indiscriminada, relevo plano. Associado ocorre Neossolos flúvicos Tb distrófico (RYbd) e Neossolos quartzarênicos hidromórficos.

\subsection{HIDRO-CLIMATOLOGIA}

Dos dez maiores rios do mundo, oito são rios tropicais e o Rio Negro é um deles. Sua bacia se estende pela Colômbia, Venezuela, Guiana e Brasil, abrangendo uma área de 696.810 $\mathrm{km}^{2}$ coberta em quase sua totalidade por uma floresta tropical. O clima é tropical úmido com uma precipitação média maior que $2000 \mathrm{~mm} /$ ano com um aumento na direção NW atingindo aproximadamente $3500 \mathrm{~mm} / \mathrm{ano}$, típico de florestas tropicais onde temperatura e precipitação apresentam um mínimo de variação anual. A região caracteriza-se por umidade constantemente alta (médias anuais entre 85 e 95\%), elevada precipitação e temperatura média anual variando entre $24^{\circ}$ e $32^{\circ}$ graus C, cuja temperatura média do mês mais frio é sempre superior a $18^{\circ} \mathrm{C}$ (FRANZINELLI; LATRUBESSE, 2003; GUYOT et al., 1993).

Na região Amazônica onde se encontra o PARNA de Anavilhanas são três os sistemas de circulação atmosférica que, combinados, definem o clima: as massas de ar equatorial, os sistemas de correntes do norte e os de corrente do sul. As estações resumem-se a duas: uma chuvosa entre outubro e maio, chamada de inverno, e outra menos chuvosa entre junho e setembro, chamada de verão.

O regime hidrológico do Rio Negro é do tipo Equatorial, exibindo dois picos máximos de descarga durante o ano. Apresenta uma descarga média anual de $29.000 \mathrm{~m}^{3} / \mathrm{s}$ e uma área de drenagem de cerca de $65.900 \mathrm{~km}^{2}$, sendo o segundo maior tributário do Amazonas em descarga depois do Rio Madeira $\left(31.000 \mathrm{~m}^{3} / \mathrm{s}\right)$, ocupando o sexto lugar do mundo em descarga de água. Rio tropical pluvial típico drena floresta tropical e exibe alto pico de descarga, porém variável durante a estação chuvosa e baixa vazão quando há redução da precipitação. De forma semelhante aos rios Congo, Tapajós e Xingu, o rio Negro transporta quantidade quase insignificante de sedimentos em suspensão para o Solimões-Amazonas, quando considerados 
suas imensas áreas de drenagem e a magnitude de suas descargas líquidas. Transporta apenas 8 milhões de toneladas anuais de sedimentos suspensos e $50 \%$ da carga é constituída de matéria orgânica, cujo conteúdo húmico é de 26,6 mg/litro (SCHMIDIT, 1972 apud PRANCE, 1980). É um típico rico de águas pretas da Bacia Amazônica, caracterizado por baixa concentração de sedimentos e nutrientes, e por águas ácidas de coloração marrom-oliva a marrom-café e transparência de 1,3 a 2,3 metros devido às substâncias húmicas dissolvidas (FILIZOLA, 1999; LATRUBESSE; STEVAUX; SINHA, 2005; LEENHEER, 1980; SIOLI, 1984).

Os rios de água preta, como o rio Negro, têm suas nascentes nos escudos arqueanos das Guianas ou nos sedimentos terciários da bacia do amazonas, cujo relevo é pouco dissecado. Aí os processos erosivos são pouco intensos, consequentemente a carga de sedimentos é baixa. A presença de florestas inundáveis e imensos areais nas áreas drenadas por esses rios, contribuem para a produção de substâncias húmicas que, aliadas à falta de cálcio e magnésio, conferem um caráter ácido às águas e consequentemente, um pH baixo e cor marrom. São consideradas águas quimicamente pobres e de baixa produtividade. As áreas inundadas por águas pretas são chamadas de igapós (PAROLIN; PIEDADE; JUNK, 2005, p.53).

\subsection{COBERTURA VEGETAL}

A Amazônia brasileira (Bioma Amazônico) possui uma área de $4.871 .000 \mathrm{~km}^{2}$ e é formada por 23 unidades biogeográficas denominadas de ecorregiões e representa cerca de 48,1\% do território brasileiro (FERREIRA, 2003). Ao mesmo tempo em que apresenta esta grande área de floresta tropical também apresenta as mais altas taxas de desmatamento. Esta floresta na área da Bacia do Rio Negro, Amazônia Central, apresenta-se em bom estado de conservação sendo considerada uma das ecorregiões de mais alta prioridade para ações de conservação em uma escala regional (OLSON et al.,1998)

O período das cheias amazônicas leva à inundação de uma vasta planície aluvial. A recorrência regular e o forte impacto da inundação promoveram, na Amazônia, o desenvolvimento de adaptações de plantas e animais e a interação entre elementos dos rios e elementos das florestas ao pulso de inundações. A qualidade da água determina a composição 
florística da planície inundada, e a vegetação em volta influencia a qualidade da água, em termos de conteúdo de oxigênio, ácidos húmicos, bioelementos adsorvidos e liberados, etc. Os organismos das florestas inundáveis são altamente adaptados à inundação, assim como os organismos dos rios estão adaptados a ter periodicamente à sua disposição uma floresta submersa que oferece abrigo, habitats para a propagação e itens alimentares tais como folhas, frutos, sementes e insetos terrestres, que caem das copas das árvores na superfície da água (PAROLIN; PIEDADE; JUNK, 2005, p.51).

As florestas inundáveis podem ser classificadas de acordo com a qualidade da água e a duração da inundação. Prance (1980) categorizou os vários tipos de florestas amazônicas sujeitas à inundação, e definiu - entre as florestas sujeitas a inundações anuais regulares dos rios - a várzea estacional (com florestas inundadas por águas brancas) e o igapó estacional (com florestas inundadas por águas pretas ou claras). De acordo com Parolin, Piedade e Junk (2005, p.53) as florestas de igapó, as florestas de várzea e as matas de terra firme possuem composição florística significativamente diferentes. Padrões de distribuição comum a várias espécies definem regiões fitogeográficas distintas.

As florestas alagadas são conhecidas como Florestas Ombrófilas Densas Aluviais no sistema de Veloso et al. (1991). Na região amazônica, a Floresta Ombrófila Densa Aluvial recebe o nome popular de várzea ou igapó dependendo da cor da água do rio, designações adaptadas para a literatura científica como sendo florestas inundáveis por águas barrentas (várzea) ou águas pretas/transparentes (igapó) (PIRES, 1974). Pires e Prance (1985) classificaram as florestas de igapó como "florestas inundadas por águas pretas ou águas claras" (Figura 13).

Segundo Junk (1993) e Irion et al. (1997), as áreas alagadas na Amazônia possuem um total de $300.000 \mathrm{~km}^{2}$, sendo $200.000 \mathrm{~km}^{2}$ de várzea e $100.000 \mathrm{~km}^{2}$ de igapó.

A constituição da flora Amazônica é adaptada à submersão total ou parcial durante um período prolongado de inundação. A vegetação é caracterizada por quatro principais comunidades de plantas: algas, plantas herbáceas aquáticas, plantas herbáceas terrestres e a floresta. Estas plantas ocupam diferentes habitats, que são influenciadas por vários fatores, entre eles: duração da fase terrestre e aquática, estabilidade do habitat pela sedimentação e erosão, corrente e ação do "banzeiro", processo de sucessão das plantas e envelhecimento do habitat e ainda, por impacto humano (JUNK; PIEDADE, 1997). 

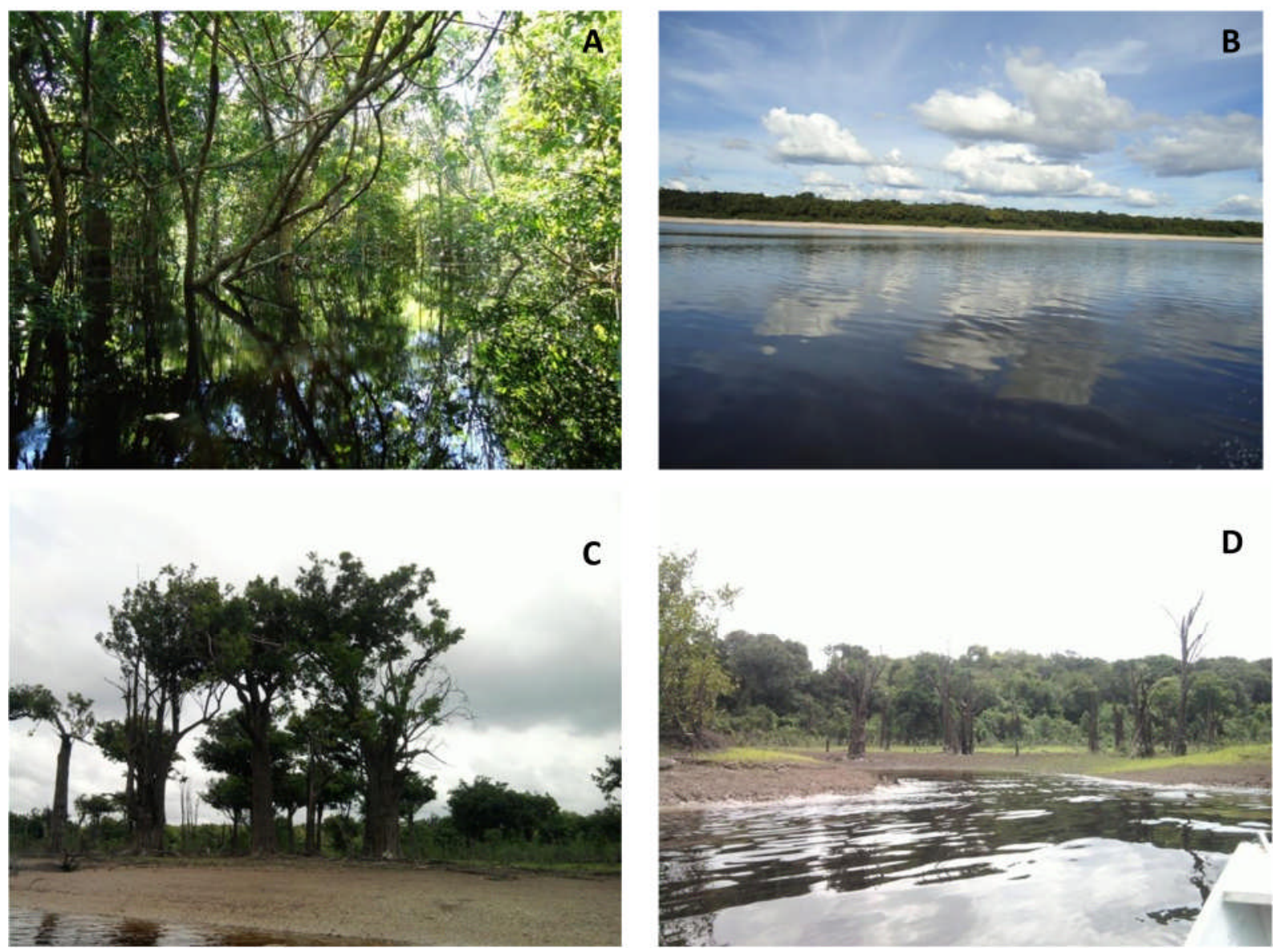

Figura 13: A: Mata de igapó; B: Floresta de Terra Firme; C: Escheweleira tenuifolia (Macacarecuia); D: Florestas inundadas de Macacarecuias (Escheweleira tenuifolia). (imagens da autora).

Junk (1989) classificou a distribuição das plantas nas áreas alagáveis da Amazônia como sendo: comunidade de arbustos falsos, comunidade arbórea de nível médio e comunidade arbórea de nível alto.

As áreas inundadas pelos rios de água preta - Florestas de igapó, em contraste com as matas de várzea, possuem solos arenosos que sustentam uma vegetação menos produtiva, onde as populações de animais é baixa. O rio Negro é o maior rio de águas pretas do mundo uma categoria de rios muito pobres em nutrientes, razão pela qual são chamados de "rios da fome". Esta pobreza dos rios em nutrientes influencia na vida dos peixes, que, para se sustentar, obtêm a maior parte de sua alimentação de matéria orgânica principalmente nas margens dos rios (insetos, frutas, flores e sementes). Por outro lado, a baixa fertilidade do ecossistema favorece a biodiversidade de alguns grupos de plantas e animais. O número de 
espécies de peixes, invertebrados terrestres e árvores nas florestas de igapó é muito elevado (PAROLIN; PIEDADE; JUNK, 2005, p.56).

A mata de igapó por sofrer inundação permanente, é um ambiente mais inóspito e estressante, o que se reflete em menor riqueza específica consequentemente estrutura florestal mais simples.

As matas de igapó do rio Negro sofrem ao longo do ano a influência dos ciclos de cheias e vazantes desse rio. A flutuação dos níveis dos rios amazônicos determina ao longo do ano a presença de uma fase aquática e uma fase terrestre, as quais as comunidades desses ambientes devem se adaptar (JUNK; BAYLEY; SPARKS, 1989). A repetição desse fenômeno em tempo geológico levou à evolução, nessa região, de um tipo particular de vegetação, adaptada a viver em submersão parcial ou total por vários meses do ano (IRON; ADIS, 1979; JUNK, 1989; PAROLIN et al., 2004). Neste ambiente a química da água somada à natureza do solo determina a estrutura da vegetação (JUNK, 1980, WITMANN; JUNK; PIEDADE, 2004). Diversos estudos a respeito da flora das águas pretas levantaram listas de espécies típicas desses ambientes.

Rodrigues, W. A. (1961), estudando a composição florística em uma ilha situada no arquipélago de Anavilhanas, no Rio Negro, reconheceu como famílias mais abundantes as Leguminosae, Annonaceae e Rubiaceae. Identificou 51 espécies, destacando: Unonopsis guatteriodes R. E. Fr., Swartzia laevicarpa Amshoff, Escheweleira sp., Heisteria sp., Pseudoxandra polypheba (Diels) R. E. Fr. e Psychotria lupulina Benth.

O trabalho realizado por Piedade et al. (2005) em dois lagos na área do arquipélago verificou que nas ilhas de Anavilhanas a vegetação apresenta nítida substituição de comunidades ao longo da topossequência, como resposta às variações no número de dias de alagação e às modificações na textura do solo, que, segundo a autora, sofreria uma gradual compactação em direção às porções mais elevadas das ilhas. Os autores diferenciam a vegetação das ilhas maiores que apresentam em média 3 estratos, porte elevado, árvores sem tortuosidade, o estrato mais alto em torno de 25 metros, e emergentes acima desse limite. $\mathrm{O}$ sub-bosque é bastante limpo, havendo apenas algumas áreas onde ocorrem cipós. As ilhas com relevo mais baixo, aparentemente mais jovens, apresentam vegetação de porte inferior sendo frequentemente inundadas totalmente durante cheias mais intensas. Devido a posição 
no relevo insular algumas plantas permanece com água ao menos na base do caule e raízes, de 340 a 270 dias ao ano.

As famílias mais abundantes em espécies por ordem decrescente identificadas foram Leguminosae, Guttiferae, Chrysobalanaceae, Annonaceae, Euphorbiaceae, Violaceae e Lecythidaceae, Lauraceae. A vegetação apresenta porte ereto, com um número reduzido de lianas e um evidente adensamento do sub-bosque nas porções mais elevadas do relevo topográfico. No sub-bosque, as famílias mais frequentes identificadas compreendem: Musaceae, Marantaceae, Zingiberaceae além de Pteridophyta.

De acordo com PIEDADE et al. (2005) a mobilidade de sedimentos das ilhas, sua constante deposição e retirada face às flutuações de nível do rio e a grande quantidade de sementes trazidas pelas águas, aliadas à existência de habitats abertos à colonização, certamente permitem a instalação de um número elevado de espécies que, à medida que a idade das ilhas avança, vão aumentando sua densidade local. As espécies menos tolerantes à alagação são excluídas ou têm sua ocorrência restrita a faixas estreitas e específicas do relevo insular. Espécies como Tovomita sp., Malouetia furfuracea e Cocoloba pichuna, são altamente adaptadas à alagação tendo sua ocorrência restrita às faixas do relevo insular alagadas em torno de 350 dias ao ano. Algumas espécies apresentam uma maior amplitude de distribuição e de tolerância a alagação, a exemplo da Nectandra amazonum, que se distribui na faixa submetida de 340 dias de alagação, e Astrocaryum jauari que se distribui na faixa de 200 dias de alagação até o topo do relevo da ilha, alagado apenas 30 dias ao ano.

A comunidade vegetal das ilhas Anavilhanas é composta de espécies que devem estar adaptadas para retirar nutrientes e centralizar seu metabolismo de crescimento durante a fase terrestre, e dispor de mecanismos de tolerância tanto à alagação e à hipoxia a ela relacionada, quanto à correnteza, especialmente nas áreas mais abertas e sob a influência dos ventos (PAROLIN et al., 2004).

Devido às características marcadamente anfíbias dos igapós das ilhas Anavilhanas, os níveis de presença/ausência de água e de ocorrência e duração de inundação, constituem-se em fatores determinantes da estrutura desses ambientes. Nessas ilhas, a água levou à evolução de comunidades extremamente adaptadas a suportar períodos prolongados de alagação. Como consequência dessa íntima relação com a água, é possível evidenciar nesses biótipos, comunidades adaptadas a viver em faixas estreitas do relevo insular, submetidas a diferentes 
números de dias de alagação ao longo do ano. Nas porções litorais são frequentes arbustos e plantas de ciclos curtos, muitas das quais desaparecem tão logo a alagação tem início. Nas porções mais elevadas tende a estabelecer-se, à medida que a ilha evolui, uma comunidade mais estável. Conclui-se, com base nesse quadro, que a substituição de comunidades ao longo da topossequência do relevo insular é resposta do número diferencial de dias de alagação ao qual cada uma delas é submetida ao longo do ano. Isso permite definir indicadores ecológicos de tolerância diferencial à alagação prolongada. Astrocaryum jauari é a espécie mais tolerante a variações de alagação, ocorrendo tanto em áreas submetidas a 340 dias de alagação até aquelas que permanecem apenas 30 dias nessa condição (PIEDADE et al., 2005). 


\section{METODOLOGIA}

Neste capítulo realizou-se uma revisão teórico-metodológica dos campos de conteúdos, das técnicas e dos conceitos-chave que deram suporte e subsidiaram a pesquisa desenvolvida e a descrição das etapas e dos procedimentos operacionais adotados para a efetivação da mesma.

\subsection{REFERENCIAL TEÓRICO-METODOLÓGICO}

As bases teórico-metodológicas mais gerais desta pesquisa estão, fundamentalmente associadas às abordagens sistêmicas, destacando-se a própria Teoria Geossistêmica, a Geomorfologia Fluvial e a Cartografia Geomorfológica. De forma mais específica quanto ao problema e área de estudo foram consideradas bases da Geomorfologia Fluvial no Trópico Úmido e Geologia Sedimentar de Ambientes Fluviais. A partir de uma visão sistêmica, considera-se que o Arquipélago de Anavilhanas é produto da ação conjunta de processos geológicos, geomorfológicos, sedimentológicos, hidrológicos e ecológicos, que podem ser abordados em suas dinâmicas e temporalidades próprias e são passíveis de serem identificados espacialmente, ou seja, delimitados, mapeados, caracterizados e mensurados. A ênfase da abordagem foi voltada à análise geomorfológica, ou seja, da articulação espacial do estudo das formas, dos materiais superficiais (solos e formações superficiais), da cobertura vegetal e da análise dos processos hidrodinâmicos de cheias e vazantes da Bacia Hidrográfica do rio Negro, para inferência dos processos geomorfológicos atuantes na área.

A Geomorfologia é a ciência que estuda as formas de relevo, formas estas que foram esculpidas pela ação de determinado processo ou grupo de processos, logo as relações entre formas e processos constituem o sistema geomorfológico, que é um sistema aberto, pois recebe influências e também atua sobre outros sistemas componentes de seu universo (CHRISTOFOLETTI, 1980). Segundo Hart (1986), a pesquisa geomorfológica, compreende a descrição da morfologia (tamanho e forma), dos materiais superficiais (formações superficiais e solos), e a análise dos processos (intempéricos, biológicos e pedológicos, erosivos, de transporte, de deposição e tectônicos). 
A pesquisa aqui proposta tem como principal ferramenta a Cartografia Geomorfológica de Detalhe ou de semi-detalhe, neste caso, a escala 1:100.000 conforme proposta por Tricart (1965). Esta se constitui em importante instrumento da espacialização dos fatos geomorfológicos, permitindo representar as características das formas de relevo (morfografia), as medidas destas formas (morfometria), e suas relações com os processos superficiais e sua dinâmica (morfodinâmica), com ênfase na hidrodinâmica atual do canal fluvial. Na elaboração desta carta, apesar da ênfase nos conteúdos interpretados da morfodinâmica atual, puderam ser considerados alguns níveis de morfogênese e de cronologia das formas.

A abordagem da Geomorfologia Fluvial no Trópico Úmido, através do estudo das formas, materiais e processos atuantes no canal fluvial nesta região climática, constitui a outra abordagem que completa o tripé que norteia a pesquisa. Os maiores rios do mundo drenam áreas tropicais, atuando como grandes condutos transferindo água e sedimentos para o oceano (GUPTA, 2011). O rio Negro, objeto de estudo deste trabalho, é um destes rios e o entendimento da sua dinâmica atual vem contribuir para o estudo de Geomorfologia Fluvial dos rios Amazônicos. Nesta pesquisa será dada ênfase aos estudos sobre os Sistemas Fluviais no Trópico Úmido, os Tipos de Canais e Planícies Fluviais nestes sistemas.

\subsubsection{Teoria Geossistêmica}

O estudo das bacias hidrográficas como unidades geomorfológicas fundamentais, adota os conceitos sistêmicos tendo em vista o funcionamento integrado de seus elementos. Os conceitos sistêmicos estão subentendidos em toda a análise morfométrica e topológica de redes fluviais (CHRISTOFOLETTI, 1979). Assim, a pesquisa proposta, conforme já citado acima, se utiliza dos conceitos sistêmicos, cujo referencial teórico apoia-se nos trabalhos de Christofoletti (1979, 1980), Gregory (1992), sistematizados em Rodrigues, C. (2001) e Vale (2004).

A Teoria Geral dos Sistemas foi proposta pelo biólogo Ludwig Von Bertalanfly como base analítica e prática para todas as ciências (GREGORY, 1992). "Esta teoria visava tanto a investigação científica dos sistemas em várias ciências quanto sua aplicação tecnológica e, 
ainda, a própria filosofia dos sistemas, no sentido de promover a discussão desse novo paradigma científico" (RODRIGUES, C., 2001).

De acordo com Klir (1987 apud VALE, 2004), embora a noção de sistema seja antiga, o conceito de sistema geral e a ideia da Teoria Geral dos Sistemas são relativamente recentes. Ludwig Von Bertalanffy a esboçou pouco antes da Segunda Grande Guerra Mundial, mas a mesma só teve publicidade quando se formou a Sociedade para o Progresso da Teoria Geral dos Sistemas em 1954, que mais tarde foi chamada de Sociedade para a investigação em Sistemas Gerais.

A Teoria Geral dos Sistemas, enunciada e definida por Bertalanffy, encontrou muita resistência no meio científico e acadêmico. Entretanto, como se sabe, toda a teoria revolucionária e unificadora encontra, inicialmente, uma forte tendência à rejeição, pois derruba pressupostos, dogmas e teorias já assimiladas pela sociedade (VALE, 2004, p.18).

Desde 1947 Bertalanffy requintou, modificou e aplicou os conceitos da Teoria Geral dos Sistemas, tendo-a difundido por meio da publicação "General Systems Yearbook". Muitos cientistas sociais estudaram, compreenderam e aplicaram a teoria dos sistemas. Em muitas áreas a aceitação foi relutante, mas nem por isso, em outras, menos empolgante (VALE, 2004).

No passado, a ciência investigava e procurava explicar os fenômenos reduzindo-os à unidades elementares independentes umas das outras. É na investigação da totalidade que reside o maior propósito da Teoria Geral dos Sistemas, embora ainda seja considerado um conceito vago e nebuloso para alguns ramos da ciência (VALE, 2004, p.21).

A Teoria Geral dos Sistemas define sistema como complexo de componentes em interação, conceitos característicos das totalidades organizadas, tais como interação, soma, mecanização, centralização, competição, finalidades, etc., e aplica-o a fenômenos concretos (VALE, 2004, p. 23)

O conceito de sistema foi adotado pela Ecologia com a elaboração da noção de ecossistema. Esta adoção permitiu integrar conceitos anteriormente isolados e desenvolveu uma nova maneira de compreender os problemas. O conceito de ecossistema foi proposto por um inglês, Tansley, no ano de 1934, cuja definição é a seguinte: o ecossistema é um conjunto 
de seres vivos mutuamente dependentes uns dos outros e do meio ambiente no qual eles vivem (TRICART, 1977b). Forsberg (1963, p.2 apud GREGORY, 1992) ampliou as definições de Tansley:

\begin{abstract}
"Um ecossistema é um sistema em interação funcional composto de um ou mais organismos vivos e de seu efetivo meio ambiente, tanto físico quanto biológico... A descrição de um ecossistema pode incluir suas relações espaciais, inventários de seus aspectos físicos, seus habitats e nichos ecológicos, seus organismos e suas reservas básicas de matéria e energia; a natureza de seu recebimento (ou input) de matéria e energia; e o comportamento ou tendência de seu nível de entropia".
\end{abstract}

Tricart (1977b, p.19) frisa que:

\begin{abstract}
"um sistema é um conjunto de fenômenos que se processam mediante fluxos de matéria e energia. Esses fluxos originam relações de dependência mútua entre os fenômenos. Como consequência, o sistema apresenta propriedades que the são inerentes e diferem da soma das propriedades dos seus componentes. Uma delas é ter dinâmica própria, específica do sistema".
\end{abstract}

Gregory (1992) define um sistema como um conjunto de elementos com características variáveis; as relações entre as características dos elementos; as relações entre o meio ambiente e as características dos elementos. Ainda segundo este autor, a atenção pode ser dirigida para a estrutura do sistema, seu comportamento, que envolve transferência de energia, seus limites, seu ambiente, seu estado, seja de transição ou de equilíbrio, e seus parâmetros, que não são afetados pela operação do sistema.

A totalidade dos sistemas que interessam ao geógrafo praticamente não atua de modo isolado, mas funciona dentro de um ambiente e faz parte de um universo maior. Esse conjunto maior, no qual se encontra inserido o sistema particular que se está estudando, pode ser denominado de universo, o qual compreende o conjunto de todos os fenômenos e eventos que, através de suas mudanças e dinamismo, apresenta repercussões no sistema focalizado, e também de todos os fenômenos e eventos que sofrem alterações e mudanças por causa do comportamento do referido sistema particular. Os primeiros podem ser considerados como sistemas antecedentes ou controlantes e os seguintes como sistemas subseqüentes ou controlados (CHRISTOFOLETTI, 1979). 
De acordo com Christofoletti (1980) um sistema pode ser definido como o conjunto dos elementos e das relações entre si e entre seus atributos. No estudo da composição dos sistemas, aspectos como matéria, energia e estrutura devem ser abordados. A matéria corresponde ao material que vai ser mobilizado através do sistema, no caso do sistema hidrológico a matéria é representada pela água e detritos. A energia corresponde às forças que fazem o sistema funcionar, gerando a capacidade de realizar trabalho. A estrutura do sistema é constituída pelos elementos e suas relações, expressando-se através do arranjo de seus componentes.

Christofoletti (1979) classifica os sistemas em sistemas isolados e sistemas nãoisolados. Os sistemas isolados são aqueles que, dadas as condições iniciais, não sofrem mais nenhuma perda nem recebem energia ou matéria do ambiente que os circundam; os sistemas não-isolados mantêm relações com os demais sistemas do universo no qual funcionam, podendo ser subdivididos em fechados, quando há permuta de energia, mas não de matéria; e em sistemas abertos onde ocorrem constantes trocas de energia e matéria, tanto recebendo como perdendo. O autor cita a classificação de Chorley e Kennedy (1971) que distinguem onze tipos de sistemas, e define apenas os mais diretamente relacionados com a Geografia: os sistemas morfológicos, que correspondem às formas, sobre as quais se podem escolher diversas variáveis a serem medidas (comprimento, altura, largura, declividade, granulometria, densidade e outras); os sistemas em sequência que são compostos por cadeia de subsistemas dinamicamente relacionados por uma cascata de matéria e energia; os sistemas de processosrespostas formados pela combinação de sistemas morfológicos (forma) e sistema em sequência (processo), cuja ênfase maior é identificar as relações entre o processo e as formas que dele resultam; e os sistemas controlados que apresentam a atuação do homem sobre os sistemas de processos-respostas

O conceito de sistema é, atualmente, o melhor instrumento lógico disponível para o estudo dos problemas do meio ambiente. Ele permite adotar uma atitude dialética entre a necessidade de análise - que resulta do próprio progresso da ciência e das técnicas de investigação - e a necessidade, contrária, de uma visão de conjunto, capaz de ensejar uma atuação eficaz sobre esse meio ambiente (TRICART, 1977b, p.19 apud VALE, 2004)

Rodrigues, C. (2001) faz um breve relato sobre a Teoria Geral dos Sistemas onde evoca que um dos primeiros ramos científicos a utilizá-lo foi a Ecologia, e que na Geografia 
sua penetração foi maior na Geografia Física do que na Geografia Humana, tendo em vista a abordagem positivista e a natureza preferencialmente indutiva da Geografia Física. A partir desta teoria, surgiram para a Geografia Física diversas propostas de modelos conceituais, morfológicos, de classificação de sistemas, incluindo os naturais. Destaca que a noção de paisagem tem como suporte lógico esta teoria, assim como a abordagem ecodinâmica de Tricart (1977b), os esquemas propostos por Sotchava (1977, 1978) e Bertrand (1972) e os preceitos de Hack (1960) na Geomorfologia, quando este aprofunda a ideia de equilíbrio na natureza e da existência de ajustes recíprocos entre sistemas, subsistemas e suas variáveis.

A perspectiva da análise integrada do sistema ambiental converge para a perspectiva da abordagem sistêmica da Teoria Geral dos Sistemas, tendo como maior vínculo a noção e conceituação do Geossistema, termo criado pelo geógrafo russo Victor Sotchava, em 1960, para estudar a espacialidade dos fenômenos geográficos (VALE, 2004 p.46).

Apesar de formulada pela escola russa, a Teoria Geossistêmica foi difundida no mundo ocidental pela escola francesa e por iniciativa de G. Bertrand em 1968. No Brasil, a teoria foi difundida por meio dos periódicos do extinto Instituto de Geografia da Universidade de São Paulo que publicou o texto de Bertrand (1972) e a tradução dos artigos de Sotchava (1977, 1978) nos cadernos de Biogeografia e Métodos em Questão (RODRIGUES, C., 2001).

Os princípios básicos da Teoria Geossistêmica proposta por Sotchava (1977) apud Rodrigues, C. (2001) incluem a consideração da natureza como sistemas dinâmicos abertos e hierarquicamente organizados, passíveis de delimitação ou de serem circunscritos espacialmente em sua tridimensionalidade; outro princípio básico é o bilateral, ou dual, dos geossistemas, em que se analisa, por um lado, a estrutura homogênea que caracteriza o geômero e, por outro lado, as qualidades integrativas dos geossistemas, que caracterizaria o geócoro; e por fim, a noção de dinâmica, pela qual é possível classificar os geossistemas de acordo com seu estado ou estados sucessivos, assim como é possível assumir ou propor hipóteses sobre sua dinâmica futura, característica fundamental para a aplicação ou para o planejamento.

A abordagem sistêmica em Geografia Física foi adotada sucessivamente pela Biogeografia, Geografia dos Solos, Climatologia e Geomorfologia, cujo processo de adoção estendeu-se por trinta e cinco anos, de 1935 a 1971, quando Chorley e Kennedy (1971) 
publicaram o livro Physical Geography: A systems approach. A incorporação das ideias desta abordagem sistêmica cresceu e foi mais significativa entre 1965 e 1975 (GREGORY, 1992).

A teoria geossistêmica faz parte de um conjunto de tentativas ou de formulações teórico-metodológicas da Geografia Física, surgidas em função da necessidade da Geografia lidar com os princípios da interdisciplinaridade, síntese, com a abordagem multiescalar e com a dinâmica, fundamentalmente, incluindo-se prognoses a respeito desta última (RODRIGUES, C., 2001).

Sobre a importância do pensamento sistêmico Capra apud Vale (2004) afirma:

\begin{abstract}
"A visão sistêmica da vida é ilustrada de maneira bela e profusa nos escritos de Paul Weiss, que trouxe concepções sistêmicas às ciências da vida a partir de seus estudos de Engenharia, e passou toda a sua vida explorando e defendendo uma plena concepção organísmica da Biologia. [...] $\mathrm{Na}$ abordagem sistêmica, as propriedades das partes podem ser entendidas apenas a partir da organização do todo. Em consequência disso, o pensamento sistêmico concentra-se não em blocos de construção básicos, mas em princípios de organização básicos. O pensamento sistêmico é "contextual", o que é o oposto do pensamento analítico. A análise significa isolar alguma coisa a fim de entendê-la; o pensamento sistêmico significa colocá-la no contexto de um todo mais amplo (CAPRA, 1996, p.40-41)
\end{abstract}

A Teoria Geral dos Sistemas, postulada, de fato, por Bertalanffy, ou o próprio "pensamento sistêmico", elaborado por tantos cientistas ao longo do tempo abriu caminho não apenas para mais uma "teoria", mas para uma nova visão do mundo, cujos princípios são os da totalidade, da abrangência das partes, de uma visão holística. Uma visão que concebe a natureza de forma integrada, onde nada pode ser entendido separadamente, onde vários campos de estudos podem ser, não unificados, mas complementados (VALE, 2004, p.47).

É no âmbito dessa visão geossistêmica que esta pesquisa encontra sustentação. Isso se coloca, por exemplo ao selecionar a ferramenta da cartografia geomorfológica como articuladora dos diversos campos do conhecimento que deverão ser correlacionados seja no nível descritivo ou interpretativo. Assim, as informações e variáveis geológicas, morfológicas, hidrológicas, sedimentológicas, pedológicas e de cobertura vegetal deverão ser integradas e hierarquizadas. Essas variáveis e sua espacialização, na estrutura do sistema particular complexo de Anavilhanas, poderão ser consideradas de primeira grandeza ou não, determinando os sistemas antecedentes ou controladores. Tome-se como exemplo a tectônica, que controla a rede hidrográfica regional ou o efeito de barramento hidráulico do rio 
Solimões, não apenas sobre o rio Negro, mas em todos seus afluentes. A distribuição dos materiais superficiais, o processo de formação das ilhas e a hidromorfodinâmica atual do complexo sofrem mudanças e alterações devido à dinâmica deste sistema particular e poderão ser, portanto, classificados como sistemas subseqüentes ou controlados.

\subsubsection{Cartografia Geomorfológica}

O segundo apoio deste estudo trata da Cartografia Geomorfológica e proposta de legenda para a elaboração do mapa hidromorfodinâmico da área de estudo. Sua concepção apoia-se nos estudos de Tricart (1963, 1965), Demék (1972), RADAMBRASIL (1978), Coltrinari (1975, 1982, 1984), Rodrigues (1997), Santana (2007) e Luz (2010).

A carta geomorfológica resulta de levantamento sistemático do terreno, reúne observações diretas, sintetizando-as. Constitui a base da pesquisa e não a concretização gráfica da pesquisa já feita. A carta geomorfológica de detalhe deverá satisfazer às seguintes exigências: fornecer elementos de descrição do relevo, identificar a natureza geomorfológica de todos os elementos do terreno e datar as formas do relevo (TRICART, 1963).

A carta geomorfológica de detalhe é a base de qualquer conhecimento criterioso de uma região, e como tal, constitui o ponto de partida quase necessário da geomorfologia aplicada (TRICART, 1963).

As cartas geomorfológicas de detalhe têm como objetivo fornecer uma descrição completa de todos os elementos do relevo e do modelado da região a que se referem (TRICART, 1965).

Baseando-se em Tricart (1965), Coltrinari (1984), em seu estudo sobre as Cartas geomorfológicas de detalhe, define-as como cartas temáticas que fornecem uma descrição completa de todos os elementos do relevo e do modelado da região a que se referem, e que, estas devem conter informações, tão precisas quanto possível, a respeito da morfometria, morfografia, morfodinâmica e a cronologia das formas. Os dados morfométricos são os que traduzem as dimensões das formas e das formações superficiais que as recobrem ou a partir das quais foram elaboradas. A morfografia refere-se à forma real de cada feição da superfície terrestre. As informações da morfodinâmica referem-se à recomposição das etapas através das 
quais uma paisagem transformou-se até atingir as características atuais. A cronologia das formas que se refere às fases morfogenéticas das formas.

"O mapa geomorfológico torna-se um dos principais instrumentos de análise da pesquisa geomorfológica quando concebido nos moldes das "Cartas Geomorfológicas de Detalhe" conforme Tricart (1965) e Coltrinari (1982, 1984)" (LUZ, 2010, p.21).

Em uma carta geomorfológica podem figurar categorias de fenômenos de dimensões muito diferentes, tanto espaciais como temporais, cuja representação dependerá da escala escolhida (COLTRINARI, 1982)

Tricart (1965) descreve duas diferentes famílias de cartas: as cartas de pequena escala (1:500.000 a menores) e as cartas de detalhe (1:5.000, 1:10.000, 1:20.000 ou 1:25.000, excepcionalmente nas escala 1:50.000 e 1:100.000). As cartas geomorfológicas de pequena escala são utilizadas para a cartografação dos conjuntos de relevo de dimensões quilométricas. A influência das forças externas aparece de maneira restrita. As cartas de detalhe apresentam características distintas. De forma preferencial são focalizados os processos que criam formas, e o modelado. Podem figurar nessas cartas objetos de tamanho decamétrico (terraços, nichos) e conjunto e feições que atinjam essa dimensão (campos de matacões), enquanto o relevo permanece em segundo plano (TRICART, 1965; COLTRINARI, 1982).

Rodrigues, C. (1997) cita como conteúdos da cartografia geomorfológica, a geometria das formas, a natureza das formas, a natureza dos materiais, a idade das formas e dos materiais. Tricart (1979 apud Rodrigues, C., 1997), afirma que, para atender a esta concepção, a carta geomorfológica deve apresentar, necessariamente informações sobre todos os seguintes aspectos: geometria das formas (devido às relações entre formas, processos e materiais), natureza do material, formações superficiais e substrato, idade das formas e dos materiais conexos da morfogênese.

\footnotetext{
"Mas se o objetivo desta cartografia é reconhecer em escalas semelhantes ou maiores que a própria representação atributos 'morfológicos e morfométricos', atributos físico-químicos e estratigráficos das 'formações superficiais e solos', interpretações sobre 'morfocronologia' (idade das formas), 'morfogênese' (origem das formas) e 'morfodinâmica' (processos ativos) isto ainda não representa o conteúdo total. Parte do conteúdo explicativo (gênese das formas) muitas vezes impõe a necessidade de outras informações como é o caso da litologia e da estrutura" (RODRIGUES, C., 1997, p.89-90).
} 
Assim, a presente pesquisa propõe a elaboração da Carta Geomorfológica de Detalhe da área do Arquipélago de Anavilhanas, na escala 1:100.000, focalizando principalmente os atributos morfológicos, morfométricos e morfodinâmicos, no caso, principalmente hidromorfodinâmicos.

\subsubsection{Geomorfologia Fluvial no Trópico Úmido}

A abordagem da Geomorfologia Fluvial no meio tropical úmido, mais específica ao tema da pesquisa, apoiou-se nos estudos de Gupta (2011), Knighton (1998), Latrubesse; Stevaux e Sinha (2005), Latrubesse (2008), Leopold, Wolman e Miller (1964), Nasson e Knighton (1996).

Os Trópicos são, em essência, uma zona climática, embora o único componente meteorológico comum a todo o cinturão de baixas latitudes seja as elevadas temperaturas. Existem consideráveis variações climáticas em toda a zona tropical, e a mais expressiva é a variabilidade da intensidade das chuvas. Estes podem ser divididos em duas unidades principais com base no índice pluviométrico anual: trópicos úmidos e tropicais áridos. Cerca de metade da superfície tropical da terra é úmida, com precipitação anual superior a evapotranspiração. As demais superfícies são sub-úmidas ou áridas. Certas características climáticas, como alta temperatura, alta intensidade das chuvas e alta evapotranspiração potencial são geralmente associadas aos trópicos, mas não ocorrem com a mesma intensidade em todos os lugares (GUPTA, 2011).

Formalmente, os trópicos podem ser definidos como uma área de excedente radiativo na interface terra-atmosfera, delimitada pelas circulações anticiclônicas proximamente as latitudes $30^{\circ}$ Norte e Sul (REYNOLDS, 1985 apud GUPTA, 2011).

De acordo com Gupta (1993 apud GUPTA, 2011) até a segunda metade do século XX ou mais, o ensino de geomorfologia nos países tropicais foi efetuado utilizando livros-texto escritos para estudantes europeus ou da América do Norte, que não refletiam o ambiente tropical e raramente apresentavam exemplos locais ou regionais. Durante anos, os estudos de geomorfologia nos trópicos foram impulsionados por dois conceitos: o de região morfoclimática e do ciclo de erosão Davisiano. A típica paisagem tropical era percebida como 
uma superfície de erosão estável, cravejada com colinas baixas (inselbergs) e coberta por solo e rochas profundamente alteradas.

A Geomorfologia tropical começou a perder sua abordagem essencialmente baseada no clima na segunda metade do século XX. Gupta (2011) apresenta um pequeno relato da evolução dos estudos de geomorfologia no meio tropical a partir desta data. Os tipos de rochas e a histórica geológica local começaram a ser utilizadas como fatores importantes para explicar a paisagem. Ao mesmo tempo, um grande número de estudos de casos começaram a aparecer, cuja abordagem era baseada nos processos, como o intemperismo das rochas, os processos erosivos, os deslizamentos de terra, e os processos morfológicos e sedimentares no sistema fluvial. Tudo isso ocorre associada à difusão dos conceitos modernos, técnicas e publicação de livros didáticos sobre o tema. A partir de 1970 ocorreu um aumento na quantidade e qualidade dos trabalhos ligados à geomorfologia tropical. Livros didáticos e discussões de estudos de casos em geomorfologia, apresentando uma conotação tropical começaram a aparecer a exemplo dos trabalhos de Douglas (1977) e Schumm (1977). A nova pesquisa indicou que os mesmos processos geomorfológicos que operaram nos trópicos também operaram em outros locais, mas com taxas e intensidades diferentes (SELBY, 1993 apud GUPTA, 2011).

A Geomorfologia Tropical, segundo este autor, aborda três áreas principalmente: geologia (materiais), as formas e os processos geomorfológicos; a transferência de água e sedimentos das encostas para o oceano, principalmente através de sistemas fluviais; as alterações antropogênicas das taxas e processos naturais, associada à degradação ambiental, relacionando os princípios geomorfológicos para a melhor gestão ambiental. Estes podem ser colocados em uma lista de tópicos específicos a serem estudados. O quadro 1 mostra uma combinação de fatores comuns e específicos que caracterizam a geomorfologia tropical (GUPTA, 2011). 
Quadro 1: Descrição resumida da Geomorfologia Tropical

\begin{tabular}{|l|l|}
\hline Tópico & Descrição \\
\hline $\begin{array}{l}\text { Principais em } \\
\text { Geomorfologia }\end{array}$ & $\begin{array}{l}\text { Localização dos cinturões tectônicos, vulcões, crátons, vales aluviais, } \\
\text { deltas, etc., conforme determinado pela tectônica de placas } \\
\text { Padrões de vento e precipitação (especialmente as tempestades } \\
\text { tropicais) } \\
\text { Distribuição da cobertura vegetal } \\
\text { Desmatamento, expansão agrícola, urbanização e controle de canais. }\end{array}$ \\
\hline $\begin{array}{l}\text { Principais processos operacionais; } \\
\text { os mesmos que atuam em outras } \\
\text { partes do mundo, mas com } \\
\text { diferentes taxas e importância } \\
\text { relativa }\end{array}$ & $\begin{array}{l}\text { Intemperismo tropical e seu efeito no material da encosta e carga do rio } \\
\text { Movimentos de massas nas encostas tropicais } \\
\text { Rios, alguns dos quais são sazonais e propensos a inundações } \\
\text { Processos glaciais, glacio-fluviais e fluviais que operam nas encostas } \\
\text { de altas montanhas } \\
\text { Processos fluviais e eólicos nos trópicos áridos } \\
\text { Processos costeiros, presença de manguezais, salinas e recifes de } \\
\text { corais. } \\
\text { Movimentos tectônicos e vulcanismo }\end{array}$ \\
\hline $\begin{array}{l}\text { Glaciações Pleistocênicas das montanhas tropicais } \\
\text { Mudanças climáticas } \\
\text { Mudança do nível do mar que afetam a zona costeira e baixos trechos } \\
\text { de rios }\end{array}$ \\
\hline $\begin{array}{l}\text { Mudanças devido a atividades antropogênicas } \\
\text { Aquecimento global e mudanças climáticas }\end{array}$ \\
\hline Mudanças atuais e futuras
\end{tabular}

Fonte: GUPTA (2011, p.8)

\subsubsection{Sistemas Fluviais no Trópico Úmido}

De acordo com Latrubesse, Stevaux e Sinha (2005) ocorreu, nas últimas décadas, um avanço dos estudos de Geomorfologia Fluvial nos grandes sistemas fluviais sob diferentes zonas climáticas, cujos principais enfoques foram os processos morfogenéticos, sedimentológicos e hidro-sedimentológicos, a hidrologia de inundação e a relação entre o tectonismo e os processos fluviais. Os autores ressaltam que apesar deste avanço o conhecimento dos rios tropicais ainda é bastante limitado devido à grande extensão das regiões tropicais e a magnitude desses rios.

Muitos dos grandes rios e dos mega-leques do mundo estão situados em áreas tropicais e demandam uma análise individualizada devido à variedade de estilos dos processos sedimentares e geomorfológicos atuantes serem praticamente desconhecidos. Grandes bacias como as dos rios Amazonas, Orinoco e Congo incluem tributários que estão entre os maiores rios do mundo (Quadro 2). Estes rios drenam áreas com precipitações acima de $700 \mathrm{~mm} / \mathrm{ano}$ e as suas bacias hidrográficas apresentam tamanho entre 103 a $106 \mathrm{~km}^{2}$ (LATRUBESSE; STEVAUX; SINHA, 2005). 
Quadro 2: Grandes rios do mundo

\begin{tabular}{|l|l|r|r|r|r|l|}
\hline \multicolumn{1}{|c|}{ Rio } & País da foz & $\begin{array}{c}\text { Descarga } \\
\text { média anual } \\
\left(\mathbf{m}^{\mathbf{3}} / \mathbf{s}\right)\end{array}$ & $\begin{array}{c}\text { Área de } \\
\mathbf{d r e n a g e m} \\
\left(\mathbf{1 0 3} \mathbf{~ k m}^{\mathbf{2}}\right)\end{array}$ & $\begin{array}{c}\text { Qs anual } \\
\left(\mathbf{1 0 ^ { 6 }} \text { ton/ano }\right)\end{array}$ & $\begin{array}{c}\text { Suprimento } \\
\text { sedimentar } \\
\left(\mathbf{t o n} / \mathbf{k m}^{\mathbf{2}} / \mathbf{a n o}\right)\end{array}$ & $\begin{array}{l}\text { Padrão } \\
\text { dominante do } \\
\text { canal }\end{array}$ \\
\hline Amazonas & Brasil & $209.000^{\mathrm{a}}$ & 6100 & $\sim 1000^{\mathrm{c}}$ & 167 & Anabranches \\
\hline Congo & Zaire & 40.900 & 3700 & 32,8 & 9 & Anabranches \\
\hline Orinoco & Venezuela & $35.000^{\mathrm{d}}$ & 950 & $150^{\mathrm{d}}$ & 157,8 & Anabranches \\
\hline Yangtze & China & 32.000 & 1943 & $970^{\circ}$ & 499 & $\begin{array}{l}\text { Anabranches e } \\
\text { trechos } \\
\text { sinuosos } \\
\text { controlados } \\
\text { geologicamente }\end{array}$ \\
\hline Madeira & Brasil & $32.000^{\mathrm{a}}$ & 1360 & $450^{\mathrm{c}}$ & 330 & Anabranches \\
\hline Negro & Brasil & $28.400^{\mathrm{a}}$ & 696 & $8^{\mathrm{b}}$ & 11,5 & Anabranches \\
\hline Brahmaputra & Bangladesh & 20.000 & 610 & $520^{\mathrm{e}}$ & 852,4 & Anabranches \\
\hline Japurá & Brasil & $18.600^{\mathrm{a}}$ & 248 & $33^{\mathrm{b}}$ & 133 & Anabranches \\
\hline Paraná & Argentina & 18.000 & 2600 & $112^{\mathrm{g}}$ & 43 & Anabranches \\
\hline Mississipi & USA & 17.000 & 3200 & $330^{\mathrm{e}}$ & 102 & Meandrante \\
\hline
\end{tabular}

Fonte dos dados: ${ }^{(a)}$ Agência Nacional de Águas - ANA, ${ }^{(b)}$ Filizola (1999), ${ }^{(c)}$ Martinelli et al. (1993), (d) Meade et al. (1983), (e) Meade (1996), ${ }^{\text {(g) }}$ Amsler; Prendes (2000).

Modificado de Latrubesse (2008)

Enquanto a base do conhecimento da geomorfologia fluvial resulta dos estudos de rios menores, existe um reconhecimento maior que grandes rios são sistemas fluviais exclusivos, em termos de controles, processos e do ponto de vista da gestão (GUPTA, 2007; JUNK; BAYLE; SPARK, 1989; LATRUBESSE; STEVAUX; SINHA, 2005; POTTER, 1978).

A importância dos sistemas tropicais na transferência de sedimentos e nutrientes para os oceanos e áreas costeiras, no estoque de sedimentos nas bacias continentais e no ciclo hidrológico global, mostra que a geomorfologia de rios tropicais não recebeu a atenção necessária quando comparada aos avanços atingidos por outras disciplinas voltadas aos meios tropicais.

O rio Negro, tributário da margem esquerda do Rio Amazonas, é um dos dez maiores rios tropicais do mundo, e a abordagem das características gerais destes grandes sistemas fluviais vem dar suporte a pesquisa aqui proposta. As considerações aqui tratadas têm como referências principais os estudos de Latrubesse; Stevaux; Sinha (2005), Latrubesse (2008) e Gupta (2011). 
Quanto ao Arcabouço geológico-geomorfológico das bacias hidrográficas tropicais, as províncias geológico-geomorfológicas drenadas por rios tropicais incluem os cinturões orogenéticos, platôs/plataformas sedimentares e basálticas, áreas cratônicas, planícies em bacias sedimentares e terrenos mistos. Grandes rios geralmente cortam mais de uma província, a exemplo dos rios Amazonas e Negro.

Em relação aos regimes hidrológicos os rios tropicais apresentam regimes diversos devido à complexidade do clima tropical e as imensas áreas de suas bacias hidrográficas. As classificações para regimes de rios tropicais com base na distribuição da precipitação propõem: rios pluviais, glaciais e de regime misto. Rios que drenam florestas pluviais tropicais exibem alto pico de descarga, variável durante a estação chuvosa, e baixa vazão quando a precipitação diminui. Estes tendem a apresentarem maior variabilidade de descarga do que rios que drenam áreas de savanas.

Os autores caracterizaram a variabilidade da descarga dos sistemas fluviais tropicais utilizando-se da razão entre a máxima e a mínima descarga diária (Qmax/Qmin), baseando-se nos dados históricos disponíveis. Para a caracterização do regime de cheias foi utilizada a razão descarga máxima anual e descarga média anual (Qmax/Qmean), obtendo as seguintes considerações a partir do diagrama Qmax/Qmean versus Qmax/Qmin: a) rios com alta variabilidade de descarga também correspondem àqueles de alto regime de cheia, caracterizados por altos valores de Qmax/Qmean; b) as bacias hidrográficas em florestas pluviais mostram geralmente valores baixos tanto de Qmax/Qmean como de Qmax/Qmin, com aumento marcante para os rios de domínio de savanas; c) descargas com maior variabilidade são observadas nos sistemas de clima árido a semi-árido, que mostram altos valores de Qmax/Qmin; d) rios tropicais perenes exibem altos valores de Qmax/Qmean; e) regimes extremos são encontrados nos sistemas de monções da Índia peninsular.

No que se refere ao transporte de sedimentos as bacias dos rios tropicais de relevo alto em cinturões orogênicos ativos têm alta produção de sedimentos e respondem por 20 a $25 \%$ da carga total de sedimentos transferidos anualmente aos oceanos; rios que drenam áreas de cráton ou plataforma são caracterizados por baixo suprimento de sedimentos. Os rios de áreas cratônicas, plataformais ou de diferentes combinações de domínios geológicos em savanas ou savana-floresta mostram baixa carga sedimentar transportada quando comparados aos rios de montanha, mas altos valores frente aos rios cratônicos ou de plateau em áreas florestadas. 
Quanto à morfologia do canal, os rios tropicais têm uma grande variedade de formas de canal, muitas vezes apresentando transição entre um padrão e outro. Rios originados em cinturões orogênicos apresentam frequentemente canais sinuosos nos grandes cursos, e podem alternar trechos sinuosos e retilíneos nas drenagens médias e pequenas. Nas florestas pluviais desenvolvem meandros assimétricos e desarmônicos. Meandros harmônicos estão geralmente relacionados com rios de carga mista. Rios que drenam áreas cratônicas e de platô desenvolvem canais com baixa sinuosidade. Grandes rios de áreas florestadas desenvolvem uma intricada morfologia multicanal com um complexo de arquipélagos. A neotectônica e a topografia do embasamento também controlam a variação espacial e temporal da morfologia de muitos rios.

Em relação aos processos, morfologia e estratigrafia fluvial a Avulsão é um dos maiores processos fluviais atuantes em rios tropicais. Avulsões típicas em trechos específicos de grandes rios da bacia Amazônica como o Solimões, Moa e Ipixuna estão relacionadas a neotectonismo. Grandes leques são também característicos de sistemas tropicais, alguns estendem-se por milhares de quilômetros quadrados. Os principais fatores controladores do desenvolvimento dos leques são reconhecidamente a alta frequência de avulsões e a grande quantidade de sedimento de fundo do sistema.

\subsubsection{Planície Fluvial e Canais}

Segundo Christofoletti (1981) a planície de inundação é a faixa do vale fluvial composta por sedimentos aluviais, bordejando o curso de água, e periodicamente inundada pelas águas de transbordamento provenientes do rio. $\mathrm{O}$ autor enfatiza que para o geomorfólogo, a planície de inundação apresenta configuração topográfica específica, com formas de relevo e depósitos sedimentares relacionados com as águas fluviais, na fase do canal e na fase de transbordamento.

O estágio de margens plenas assinala a descontinuidade entre o sistema canal fluvial e o sistema planície de inundação. Até atingir o estágio de margens plenas, o escoamento das águas processa-se no interior do canal e origina diversas formas topográficas. Ultrapassado o estágio de margens plenas as águas espraiam-se e há relacionamento diferente entre as variáveis da geometria hidráulica. Embora englobando o canal fluvial, como um subsistema, a planície de inundação não deve ser confundida nem ser caracterizada pelos processos e formas de relevo desenvolvida no canal fluvial (CHRISTOFOLETTI, 1981, p.243). Essa é 
uma das principais descontinuidades dos sistemas fluviais, em que processos característicos tomam parte.

Segundo Christofoletti (1980), em trechos de canais anastomosados, a planície de inundação não é muito característica nem contínua, porque existem muitas ilhas e bancos detríticos que dividem o fluxo; por outro lado, os elementos topográficos estão em modificação rápida e contínua.

O rio Negro praticamente não tem planícies aluviais: estende-se de barreira a barreira, ou de talude de terraço até as barrancas da outra banda. Em frente de Manaus, o rio chega a atingir 22 quilômetros de largura. Mas, em compensação, apresenta dois notáveis setores de restingas fluviais sílticoargilosas centrais, fixadas por um ecossistema de florestas baixas, pouco diversificadas. Dir-se-ia que existem dois arquipélagos fluviais - tipo anavilhanas - no rio Negro: um, a montante de Manaus, outro a montante da barra do rio Branco com o Negro, conforme detectado no Projeto RADAM (AB'SABER, 2002, p.8).

Segundo Miall (1996) a migração lateral dos canais anastomosados é mínima e, portanto, a planície de inundação não possui barras laterais ou canais abandonados. Os canais tendem a ser isolados, delimitados em muitos locais por depósitos de planície de inundação. Estes são normalmente de granulação fina, os bancos do canal fluvial são coesos e com lados íngremes. As planícies de inundação são caracterizadas por lamas as quais podem conter depósitos de lagoa (pond deposits), carvão mineral, calcretes ou evaporitos, dependendo do clima. Depósitos de rompimento de diques também são comuns (Figura 14).

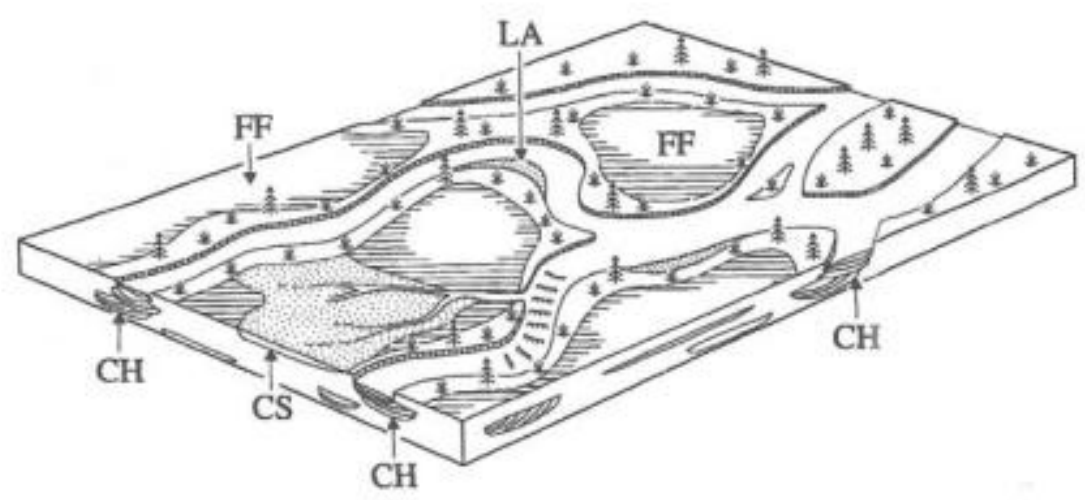

Figura 14: Planície de inundação de canais anastomosados, CH: Canal, FF: Finos da planície de inundação; LA: Macroformas de acresção lateral; CS: Depósitos de rompimento de diques.

Fonte: Miall (1996) 


\subsubsection{Tipos de Canais}

Os rios ou canais fluviais são essencialmente agentes de erosão, transporte e deposição, movimentando o suprimento de água e sedimentos da superfície terrestre para os oceanos. No desempenho de seu trabalho erosional e deposicional os rios desenvolveram e, continuam a desenvolver uma ampla variedade de redes e forma de canais. Os rios normalmente apresentam limites espaciais bem definidos e podem ser considerados como um sistema aberto no qual a energia e a matéria realizam troca com o ambiente externo (KNIGHTON, 1998).

O caráter e o comportamento do sistema fluvial em um determinado local refletem o efeito integrado de um conjunto de fatores controladores como o clima, geologia, uso do solo e a morfometria da bacia, os quais juntos determinam o regime hidrológico, a quantidade e o tipo de sedimento fornecido. O nível de base, a jusante, também é muito importante. Os rios são considerados corpos dinâmicos cujas características variam no tempo e espaço em consequência de mudanças nos padrões ambientais. As mudanças ambientais ocorridas nos últimos 20.000 anos afetaram significadamente o nível de atividade fluvial em diversas partes do mundo, embora, dada a fragilidade do canal fluvial, mudanças climáticas modestas possam desencadear maiores episódios de ajuste fluvial (KNIGHTON, 1998).

\section{a) Tipos de Canais:}

Segundo Christofoletti (1981) os tipos de canais representam mecanismos de ajustagem entre as variáveis implicadas neste sistema geomorfológico, constituindo respostas que se somam e se entrosam com as relacionadas à seção transversal e ao perfil longitudinal dos cursos de água. Cada tipo de canal possui maneiras diferentes de afetar a resistência do fluxo, existindo uma acentuada relação entre a quantidade e a característica da carga sedimentar disponível e a quantidade e variabilidade do débito, de um lado, e a tipologia dos canais, de outro.

Knighton (1998) apresenta uma discussão sobre a tipologia dos canais fluviais e considera que a classificação convencional de Leopold e Wolman (1957) dos padrões de canais em retilíneos, meandrantes e entrelaçados, é insatisfatória, e que atualmente uma ampla variedade de tipologia de canais é reconhecida, as quais incluem diferentes tipos dentre os três originais, várias formas transicionais e os rios anastomosados. Ainda segundo este autor 
Schumm $(1981,1985)$ identifica 14 padrões onde o tipo de carga transportada através do canal fluvial é considerado critério básico, com os padrões agrupados de acordo com carga de fundo (1-5), carga mista (6-10) e carga em suspensão (11-14). (Figura 15)

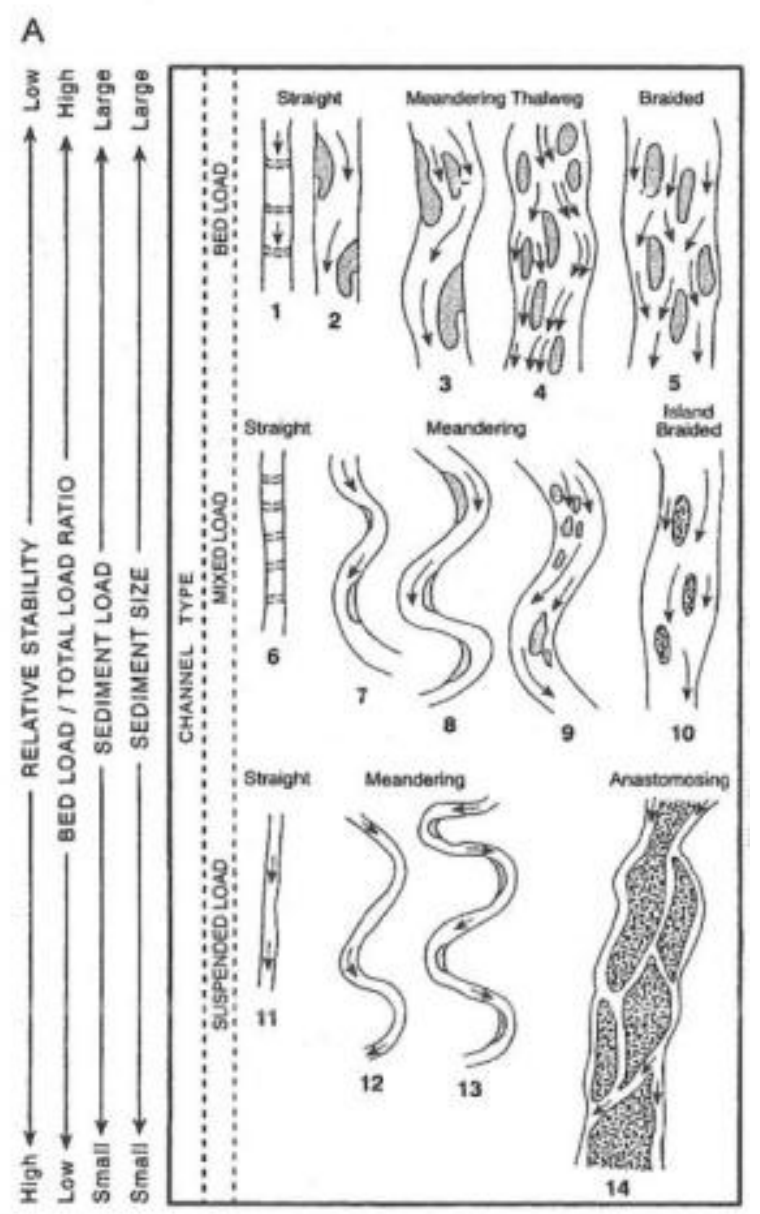

Figura 15: Classificação dos canais fluviais segundo Schumm (1981) Fonte: Knighton, 1998

De acordo com Knighton (1998) os tipos de canais podem ser considerados como um continuum entre os canais únicos e os com canais múltiplos. A sinuosidade do canal, definida como a relação entre o comprimento do canal e a distância do eixo do vale, é um segundo critério na classificação dos tipos de canais. Assim, canais únicos incluem os canais retos com leito móvel $(\mathbf{1}, \mathbf{6})$ e sem leito móvel (11), canais retos com barras alternadas e talvegue meandrante (2) gradando entre canais ligeiramente sinuosos, e várias formas de meandrantes $(8,13)$. Os canais múltiplos são diferentes apesar de Leopold e Wolman (1957) os agruparem em uma única categoria como canais entrelaçados (braided). Nos rios entrelaçados o fluxo é separado por barras definindo um canal $(\mathbf{5}, \mathbf{1 0})$, estas barras podem ser inundadas com o 
aumento da vazão e tornam-se um único canal no período de inundação. Os rios anastomosados (14) consistem de vários canais separados por ilhas estáveis com vegetação ou não, as quais comumente são arrancadas da planície de inundação e são grandes em relação à largura do canal.

Knighton (1998) enfatiza que apesar da variedade de padrões agora conhecidos, a subdivisão original em canais retilíneos, meandrantes e entrelaçados (braided) permanece relevante devido a sua associação com o conceito de continuum introduzido por Leopold e Wolman (1957). Assumindo que os padrões de canais são controlados pela interação entre um conjunto de variáveis contínuas e que todos os padrões de canais são integrados, Leopold e Wolman consideram que um continuum de padrões de canais podem existir, cada padrão seria associado com uma combinação particular dessas variáveis. O problema é identificar as variáveis significantes e determinar como elas controlam os padrões dos canais.

Os canais retos são aqueles em que o rio percorre um trajeto retilíneo, sem se desviar significantemente de sua trajetória normal em direção à foz. Os canais verdadeiramente retos são muito raros na natureza, existindo principalmente quando o rio está controlado por linhas tectônicas, como no caso de cursos de água acompanhando linhas de falha (CHRISTOFOLETTI, 1981, p.148).

O canal meandrante é o tipo de canal fluvial em que os rios descrevem curvas sinuosas, largas, harmoniosas e semelhantes entre si, através de um trabalho contínuo de escavação na margem côncava (local de maior velocidade da corrente) e de deposição na margem convexa (local de menor velocidade) (CHRISTOFOLETTI, 1981, p.163). "Este processo de escavação nas margens côncavas e deposição nas convexas é chamado de divagação meândrica onde o canal pode migrar horizontalmente tanto em direção à jusante como lateralmente, dentro da planície. Este tipo de canal é considerado o mais conhecido dentre todos devido ao grande número de estudos envolvendo este padrão" (SILVA, J. P., 2010, p. 64).

Os canais entrelaçados (braided) é o padrão que apresenta múltiplos canais separados por barras e ilhas. As barras tendem a ser mais instáveis, sem vegetação e submersas nas cheias, enquanto as ilhas são estáveis, vegetadas e emersas durante o período das cheias. A feição característica destes tipos de canais é a divisão e união de canais de forma repetida, 
associada à divergência e convergência do fluxo, o que contribui para a alta razão de atividade fluvial em relação a outros tipos de rios (KNIGHTON, 1998).

Os canais anastomosados caracterizam-se por apresentar multiplicidade de canais, pequenos e rasos, que se subdividem e se reúnem aleatoriamente, separados por bancos e ilhotas. Na época das cheias, muitos dos bancos e ilhotas são submersos, embora o entalhamento fluvial, a fixação da vegetação e a maior retenção de sedimentos possam criar condições para que muitas permaneçam acima do nível das águas. Os canais de fluxo são mutantes em suas dimensões e posições durante as variações do débito (CHRISTOFOLETTI, 1981, p. 155).

Nanson e Knighton (1996) descrevem outra categoria de rio: os rios anabranches (anabranching rives), que consistem em um padrão de canais múltiplos separados por ilhas estáveis e largas em relação ao tamanho do canal e dividem o fluxo de descargas até aproximadamente as margens plenas. Consequentemente, os padrões de fluxo nos segmentos de canais adjacentes são essencialmente independentes uns dos outros em oposição aos rios entrelaçados (BRIDGE, 1993 apud KNIGHTON, 1998).

Nos rios anabranches as ilhas normalmente persistem por décadas ou séculos, estabilizadas pela vegetação e tem aproximadamente a mesma elevação (cota) da planície de inundação. $\mathrm{O}$ canal individual de um sistema anabranches pode ser retilíneo, meandrante ou entrelaçado (SCHUMM, 1985 apud KNIGHTON, 1998). Outra característica particular deste tipo de padrão de canal é a sua ocorrência em diversos tipos de ambiente, do subártico ao tropical, do monçônico ao semi-árido, o que implica que o clima não é um fator determinante na sua formação.

Com base nas condições hidráulicas e geomorfológicas, Nanson e Knighton (1996) propuseram uma classificação para os rios anabranches em seis tipos principais, a saber:

Tipo 1: Rios anabranches com leito de sedimentos coesos (rios anastomosados): os rios anastomosados são caracterizados por baixos gradientes, baixa potência fluxo (geralmente $\leq 8$ $\mathrm{W} \mathrm{m}^{-2}$ ) e bancos coesos, com formação de canais laterais estáveis com baixa relação larguraprofundidade. Os autores reconheceram três sub-tipos com base no ambiente e condições de deposição de sedimento associados: sistemas orgânicos, organo-clásticos e lamosos; 
Tipo 2: Rios anabranches, com leito arenoso e formação de ilhas: similar em outros aspectos aos rios do Tipo 1, este possui sedimentos menos coesos. Para garantir a estabilidade das areias dos aluviões são necessários baixa potência de fluxo e a presença de vegetação;

Tipo 3: Rios anabranches, de carga mista e lateralmente ativos: estes rios com canais múltiplos tem ramificações bem estabilizadas que meandram e migram lateralmente através da planície de inundação. Eles são semelhantes aos rios do Tipo 1 (organo-clásticos), mas são lateralmente mais ativos;

Tipo 4: Rios anabranches, com leito predominantemente arenoso, formando diques: observado somente nas regiões áridas do norte e Austrália central, estes rios tem canais subparalelos separados por cristas de areias estreitas e íngremes e no topo estabilizados por vegetação;

Tipo 5: Rios anabranches, com leito predominantemente cascalhento e lateralmente ativos: comum na região cordilherana do oeste do Canadá, estes rios divagantes de leito cascalhento tem sido descrito como transicionais entre os meandrantes e entrelaçados $(\mathrm{CHURCH}, 1983$; DESLOGES; CHURCH, 1989 apud KNIGHTON, 1998).

Tipo 6: Rios anabranches, com leito predominantemente cascalhento e estáveis: um pequeno grupo de canais com baixo gradiente que responde rapidamente a eventos chuvosos e podem exibir padrão anabranches característico com ilhas cascalhentas bem vegetadas. Bastante similar ao Tipo 5, a acumulação de sedimentos e toras é a principal causa de sua formação.

De acordo com Nanson e Kinghton (1996) os seis tipos estão aproximadamente ordenados com o aumento da energia do canal, mas podem ser diferenciados com base na textura dos sedimentos e morfologia (Figura 16). 


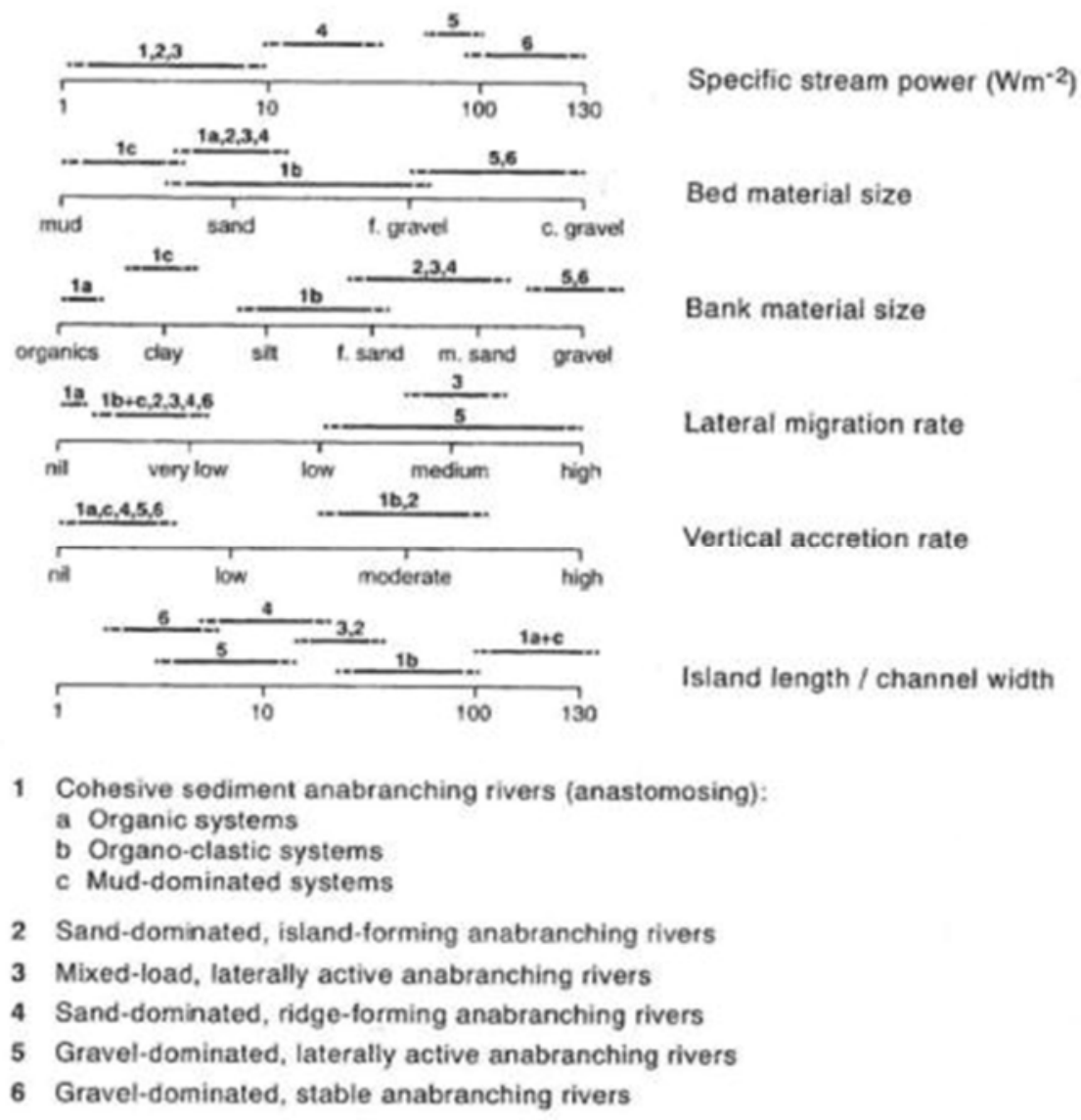

Figura 16: Diferenças entre os tipos de rios anabranches com base na potência de fluxo, sedimento, forma e processos.

Fonte: Knighton (1996)

Em geral a literatura geomorfológica mais antiga considera a região do baixo curso do rio Negro como um canal anastomosado, assim classificado por apresentar uma multiplicidade de canais (paranás) com ilhas vegetadas. No entanto, a classificação deste trecho do rio vem ultimamente sendo considerada como anabranches e sendo adotada por diversos autores (LATRUBRESSE; STEVAUX; SINHA, 2005; LATRUBESSE; FRANZINELLI, 2005). A revisão aqui proposta, com ênfase nos canais anastomosados, busca subsídios para caracterização e análise dos processos fluviais associados a este tipo de canal fluvial.

De fato o rio Negro, na área de estudo, apresenta uma complexa rede de canais múltiplos e ilhas fluviais, apesar da baixa carga de sedimentos que transporta, configurando o estilo do canal como anabranches. De acordo com Latrubesse (2008) o canal fluvial do rio Negro é controlado pela geologia (estrutura e embasamento) e não possui ampla planície de inundação. Entretanto, os blocos tectônicos permitiram o desenvolvimento de impressionantes 
arquipélagos fluviais que ultrapassam $15 \mathrm{~km}$ de largura e se estendem por centenas de quilômetros, formando assim, um Arquipélago do tipo Anabranches Complexo.

Levantamentos e análises realizadas permitem afirmar que os materiais superficiais que sustetam as ilhas do arquipélago são coesos e argilo-siltosos e/ou síltico-argilosos, com quantidades subordinadas de areia fina a muito fina com presença de silte e a carga de fundo do rio é constituída por areia média a fina. Neste estudo classificou-se o rio Negro como Rio anabranches com leito de sedimentos coesos (rio anastomosado) ou Tipo 1, de acordo com a classificação proposta por Nanson e Knighton (1996) (Figura 17). Essa questão é retomada ao final deste estudo.

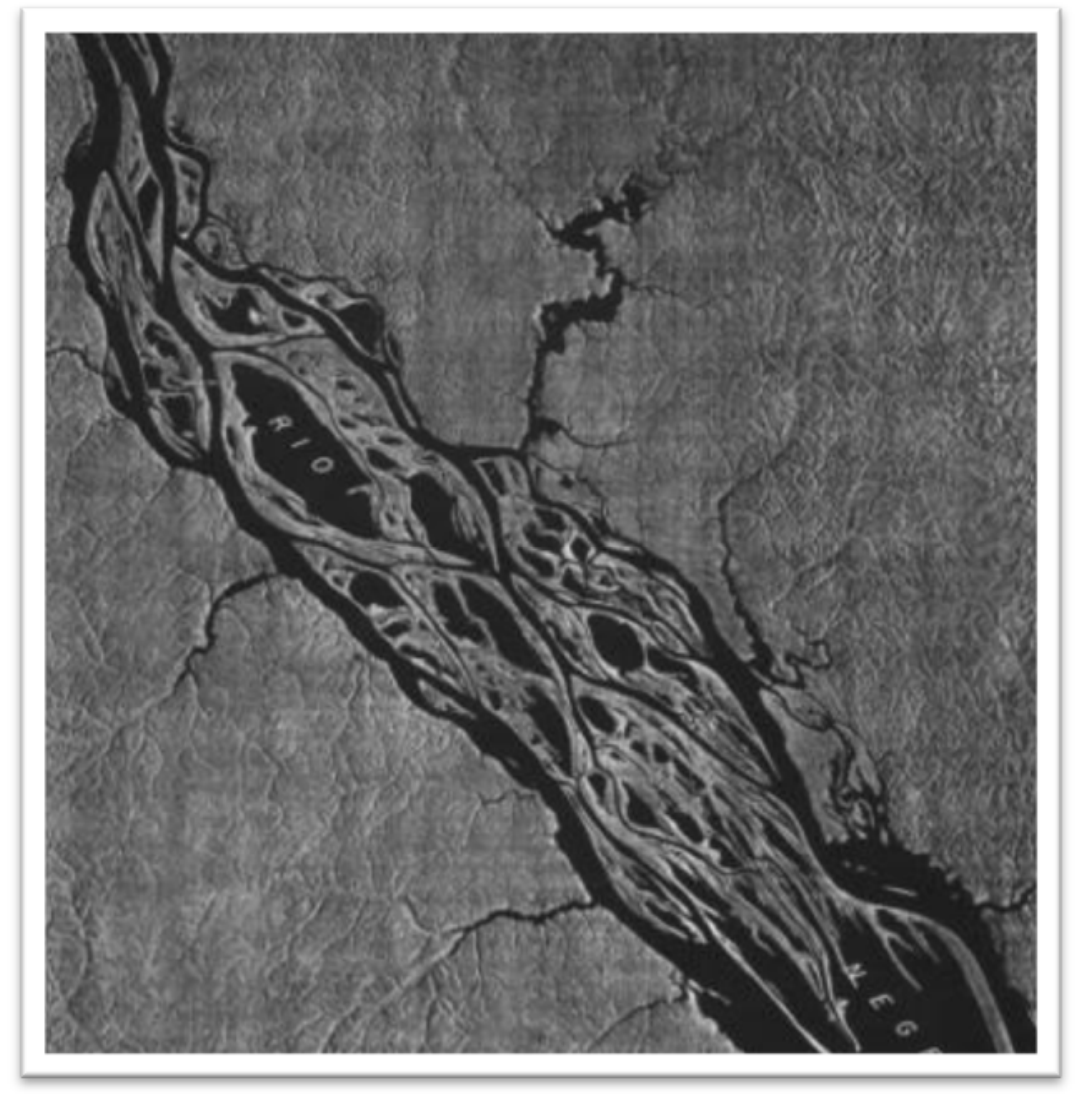

Figura 17: Rio Anabranches - Tipo 1: rio anastomosado com leito de sedimentos coesos (NANSON E KNIGHTON, 1996)

Fonte: Mosaico semi-controlado na escala 1:250.000 - RADAMBRASIL,1978

A questão da classificação do rio Negro envolve também considerar as Rias Fluviais. Tricart (1977a) descreve para a Amazônia brasileira a presença de rias fluviais e as descreve como resultado da subida do nível do mar, por ocasião da Transgressão Flandriana (Holoceno), que provocou a diminuição do gradiente dos cursos d'água e a redução maciça da carga fluvial, formando vales com déficit aluvial, cuja carga foi insuficiente para equilibrar a 
subida do nível de base e permitir a construção de um delta. Esses vales foram afogados formando extenso espelho d'água, quando as enchentes do vale principal barram o afluente e fazem subir as águas.

Ab’Sáber (2005) em discussão sobre os problemas da Amazônia brasileira, também descreve para a região a presença de rias fluviais que se formaram devido a subida do nível do mar, ocorrida nos fins do quaternário e início do holoceno, e que ficou três metros acima do nível atual e ao aumento das precipitações amazônicas fazendo com que as águas dos rios Amazonas e Solimões afogassem o baixo vale de inúmeros rios da Amazônia, criando baías de ingressão fluvial parecidas com estuários, as quais, segundo o autor, Francis Ruellan designou de "rias de água doce".

\subsubsection{Sedimentação Fluvial}

As formas de relevo originadas em ambientes fluviais estão relacionadas aos processos de sedimentação e aos erosivos. A carga detrítica fornecida aos cursos de água, transportada em suspensão ou nas proximidades da superfície do leito, possui características granulométricas variadas e se depositam conforme condições diversas na escala temporoespacial. Nos ambientes aluviais, as formas topográficas resultantes estão intimamente associadas aos processos deposicionais e a caracterização de muitos tipos de formas envolve, implicitamente, as condições de sedimentação e o arranjo estrutural do acamamento sedimentar. Outros grupos de formas topográficas encontram-se ligado aos processos erosivos atuantes no canal fluvial, resultando do ajustamento das forças exercidas pelo fluxo sobre as formações rochosas encontradas no leito e nas margens (CHRISTOFOLETTI, 1981, p.210).

Hart (1986) enfatiza o significado prático do estudo dos processos deposicionais como, por exemplo, a importância da caracterização e do mapeamento de detalhe de áreas deposicionais para a compreensão ou monitoramento de processos fluviais. A caracterização dos materiais tem sua importância associadas a fatores como resistência a ação erosiva e intemperismo, e consequentemente na quantidade de carga detrítica removida, transportada e depositada na bacia de drenagem. 
O estudo do ambiente de sedimentação fluvial significa primordialmente a determinação das condições hidrodinâmicas sob as quais determinados sedimentos foram depositados. As melhores informações sobre as condições hidrodinâmicas podem ser obtidas do estudo detalhado das estruturas sedimentares primárias, inorgânicas e orgânicas (SUGUIO, 1980). O autor adverte que apenas a presença ou a ausência de estruturas individuais não pode ser aplicada como dado positivo na interpretação ambiental, sendo necessária a definição de assembleia de estruturas sedimentares e sua presença em determinadas sequências e combinações que fornece as chaves para a interpretação ambiental, isto é, determinadas assembleias ou associações de estruturas em certos tipos litológicos são peculiares a ambientes específicos.

As estruturas sedimentares podem ser subdivididas em primárias (singenéticas) e secundárias (epigenéticas). A primeira seria resultante de processos físicos atuantes no ambiente deposicional e a segunda formada logo após ou muito tempo depois da sedimentação (feições diagenéticas tardias). Por refletirem muito bem as condições físicas do ambiente deposicional as estruturas sedimentares primárias são atributos faciológicos de vital importância na análise paleoambiental e podem ser classificadas em 03 grupos: estruturas fluidodinâmicas, estruturas deformativas e estruturas biogênicas.

A sedimentação fluvial inclui os processos de remoção, transporte e deposição da carga detrítica, envolvendo toda a dinâmica da bacia hidrográfica, cujo conhecimento minucioso das condições de atuação destes processos é extremamente importante porque se refletem nas características das camadas sedimentares que funcionam como sedimentos correlativos e vestígios das condições morfoclimáticas imperantes nas áreas continentais (CHRISTOFOLETTI, 1980).

No mapeamento realizado no Arquipélago de Anavilhanas esta pesquisa identificou estruturas sedimentares associadas a ambientes específicos, refletindo assim as condições hidrodinâmicas do meio quando da deposição destes depósitos sedimentares. As estruturas sedimentares identificadas compreendem as marcas onduladas, estratificação plano-paralela, laminação plana, gretas de contração e estruturas de bioturbação. 


\section{a) Marcas Onduladas}

Marcas onduladas são produzidas pela água em movimento sobre superfícies de materiais incoerentes. Estas estruturas sedimentares estão associadas a regime de fluxo inferior onde a resistência oferecida ao fluxo é grande e o transporte de sedimentos é relativamente pequeno. As ondulações da superfície da água não estão em fase com as ondulações do sedimento do leito. A configuração do leito é de pequenas ondulações (microondulações) ou de grandes ondulações (macro-ondulações), ou combinação delas (SUGUIO; BIGARELLA, 1990).

A interação dinâmica entre fluido e sedimentos em transporte desenvolve no leito da corrente uma série de formas características, que podem ter a seguinte cofiguração, com o aumento da intensidade de fluxo: 1) camadas planas sem movimentação; 2) pequenas ondulações; 3) mega-ondulações; 4) camada plana com movimentação de sedimentos; 5) antidunas. $\mathrm{O}$ conjunto das formas, e cada forma em si, representa a interação dinâmica entre o material do leito e o fluxo da corrente (SUGUIO; BIGARELLA, 1990).

Marcas onduladas originam-se em areia média ou mais fina quando o valor limiar de movimentação dos grãos é justamente excedido pelo fluxo unidirecional. Ou seja, as marcas de ondulação formam-se quando a velocidade do fluxo excede o valor da velocidade limiar de movimentação de grão, de acordo com Suguio e Bigarella (1990).

As macro-ondulações (Dunas) são formas assimétricas, com perfil longitudinal semelhante ao das micro-ondulações, possuindo suave declividade para montante e declividade íngreme para jusante. Estas são geradas em condições de fluxo tranquilo e formam-se em qualquer tipo de canal, independente do tamanho do material do leito, se a potência fluvial for suficiente para causar transporte geral do material do leito sem ultrapassar o valor do número de Froude $^{5}$ igual a 1,0. Considera-se que a amplitude máxima que possibilita o desenvolvimento das dunas é aproximadamente a profundidade média, assim, as dunas desenvolvem-se proporcionalmente com o aumento da profundidade, até atingir os valores limites correspondentes à profundidade média. Sob condições de fluxo estável, a

\footnotetext{
${ }^{5}$ Número de Froude (F): utilizado para se verificar se o fluxo é corrente ou encachoeirado, cuja fórmula é $F=V / V g D$, onde $V$ é a velocidade média, $\mathrm{g}$ é a força da gravidade e $\mathrm{D}$ é a profundidade da água. Se o número de Froude (F) é menor do que 1 , o rio está no regime de fluxo tranquilo, corrente; se $\mathrm{F}$ for maior que 1, o rio está no regime de fluxo rápido, encachoeirado.
} 
altura das dunas é diretamente proporcional à profundidade da água, sendo que a sua altura oscila entre 10 a $20 \%$ do valor da profundidade. As dunas são definidas como as formas que excedem $60 \mathrm{~cm}$ de comprimento e $4 \mathrm{~cm}$ de altura (CHRISTOFOLETTI, 1981).

\section{b) Estratificação Plano-paralela}

A Estratificação plana é a mais simples das estruturas intraestratais e, em geral, apresenta-se com atitude horizontal e podem ser encontradas em vários ambientes de sedimentação, desde canais fluviais e praias até em frentes deltaicas, mais comumente composta por leitos arenosos, tanto quatzosos como calcários. Este tipo de estratificação é atribuída a forma de leito plano, que ocorre mais comumente sob condição de regime de fluxo, cujo número de Froude seja próximo a 1. As partículas arenosas depositadas, sob essas condições, em geral dispõem-se com o eixo maior paralelo à direção de fluxo (SUGUIO, 2003).

\section{c) Laminação Plana:}

A laminação plana é composta por leitos, cujas espessuras correspondem à soma dos diâmetros de alguns grãos, podendo ser determinda pela alternância entre horizontes, com difreentes granulações, ou pelos diferentes teores de minerais pesados máficos, ou ambos. As laminações mais finas são bem desenvolvidas em areia fina e silte (SUGUIO, 2003).

\section{d) Gretas de Contração e Estruturas de Bioturbação}

As gretas de contração, também conhecidas como gretas de ressecação, são pequenas fendas estreitas produzidas pela desidratação. Este fenômeno é muito comum nas argilas, indicando sucessão de épocas de inundação seguida de exposição, dando origem a desagregação de pequenos polígonos e solos poligonais por causa do fendilhamento produzido pela desidratação. A espessura dos polígonos do solo está na dependência da espessura da argila e do grau de dessecamento sofrido (GUERRA; GUERRA, 2009; SUGUIO, 2003).

As estruturas de bioturbação abragem feições produzidas pelas atividades, em vida, dos animais (zooturbação) e plantas (fitoturbação) no interior ou nas superfícies dos depósitos sedimentares (SUGUIO, 2003). 


\subsubsection{Erosão Fluvial}

A erosão fluvial engloba os processos que resultam na retirada de detritos do fundo do leito e das margens, fazendo com que passem a integrar a carga sedimentar. A erosão fluvial é realizada através dos processos de corrosão, corrasão e cavitação. A corrosão, no âmbito da geomorfologia fluvial, engloba todo e qualquer processo químico que se realiza como reação entre a água e as rochas superficiais que com ela estão em contato; a corrasão ou abrasão é o desgaste pelo atrito mecânico, geralmente através do impacto das partículas carregadas pela água; a cavitação ocorre somente sob condições de velocidade elevada da água, quando as variações de pressão sobre as paredes do canal facilitam a fragmentação das rochas (CHRISTOFOLETTI, 1981, p. 235-236).

$\mathrm{Na}$ área de pesquisa durante o período de estiagem e subida das águas é comum a ocorrência de processo erosivo diagnosticado pela frequente ocorrência de "Terras Caídas", nas margens das ilhas localizadas no canal principal, nos diversos paranás que constituem a rede hidrográfica local e na Terra Firme. É importante frisar que, na Amazônia, o termo “Terras Caídas" é bastante utilizado para descrever os processos erosivos nas margens dos rios de água branca, apesar deste fenômeno ocorrer também nas margens dos rios de águas pretas e claras.

Terras caídas é um termo regional amazônico usado principalmente para designar erosão fluvial acelerada que envolve desde os processos mais simples a altamente complexos, englobando indiferenciadamente escorregamento, deslizamento, desmoronamento e desabamento que acontece às vezes em escala quase que imperceptível, pontual, recorrente e não raro, catastrófico, afetando em muitos casos distâncias quilométricas. É um fenômeno predominantemente complexo, inter-relacionado causado por fatores hidrodinâmico, hidrostático, litológico, climático, neotectônico e ainda que em pequena escala antropogênica (CARVALHO, J. A. L., 2006).

Tricart (1977a) atribui à forte amplitude das oscilações de descarga dos rios amazônicos o solapamento de suas margens nos períodos de subida das águas: “Árvores são desenraizadas e tombadas no leito. Elas aumentam a turbulência e provocam muitas vezes a formação de nichos de turbilhonamento que fazem chanfraduras nas margens". Para o autor: “A vazante, por seu lado, dá origem a numerosos furos semicirculares nas aluviões argiloarenosas, que ficam saturadas durante a submersão. A pressão hidrostática desempenha 
importante papel nesse fenômeno. Em geral, ele forma nichos semicirculares. Deles resultam pacotes escorregados ou uma pequena língua, lavados, na maioria das vezes, por ocasião das vazantes" (TRICART, 1977a, p.10).

Existem na literatura diversos relatos de naturalistas, cronistas e viajantes sobre o fenômeno das "Terras Caídas" na região Amazônica, principalmente devido aos riscos que estas ofereciam à navegação próxima das margens. Um dos relatos mais interessantes é o de Euclides da Cunha durante viagem ao rio Purus.

\begin{abstract}
Realmente nesse afonoso derruir de barrancas, para torcer-se em seus incontáveis meandros, o Purus entope-se com as raízes e troncos das árvores que o marginam. [...] Não raro o viajante, à noite, desperta sacudido por uma vibração de terremoto, e aturde-se apavorado ouvindo logo após o fragor indescritível de miríades de frondes, de troncos, de galhos, entrebatendo-se, rangendo, estalando e caindo todos a um tempo, num baque surdo e prolongado, lembrando o assalto fulminante de um cataclismo e um desabamento da terra. São, de fato, as 'terras caídas' (EUCLIDES DA CUNHA, 2003, p. 69 apud CARVALHO, J. A. L., 2006).
\end{abstract}

Carvalho, J. A. L. (2006) conclui que as terras caídas no rio Amazonas resultam de um processo muito mais dinâmico e complexo do que aparece na literatura, resultado da ação conjugada de vários fatores como: a pressão hidrodinâmica da água canalizada imprimida pela velocidade e por uma descomunal descarga fluvial; a pressão hidrostática exercida pelo peso e capacidade de desagregação da água no pacote sedimentar, causada pela ação conjugada da pressão hidráulica do rio com a água retida pelo transbordamento e pela ação da água precipitada durante as pesadas chuvas; a composição do material que constitui as margens dos rios de água branca, que no caso da várzea é composto principalmente por areia fina inconsolidada, silte e argila; fatores estruturais e tectônicos que atuam como controladores do processo de deposição e erosão; fatores climáticos como os ventos, as temperaturas elevadas e chuvas torrenciais; fatores antropogênicos como desmatamentos das margens e as embarcações que cada vez mais potentes, provocam deslocamento de massa líquida formando banzeiro cada vez maior, aumentando a capacidade de solapamento das margens (CARVALHO, J. A. L., 2006, p.67). 


\subsection{PROCEDIMENTOS}

Os procedimentos adotados nas etapas definidas para a pesquisa compreendem os planos de pesquisa dos levantamentos de dados, a sistematização, as análises e discussão dos resultados, que podem ser visualizadas no fluxograma abaixo:

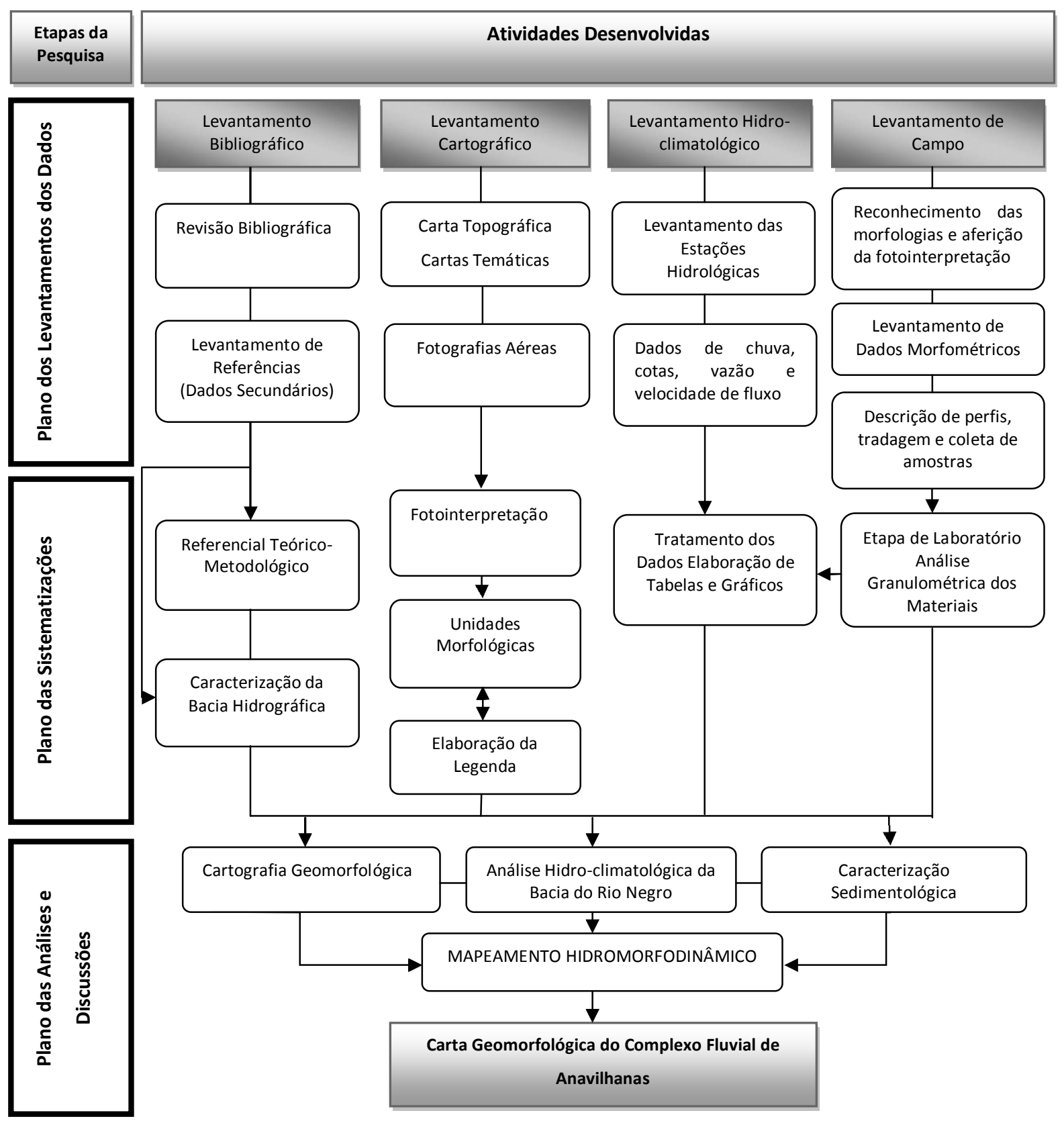

Figura 18: Fluxograma das Etapas da Pesquisa 


\subsubsection{Levantamento dos Dados}

Esta etapa da pesquisa envolveu o levantamento de dados bibliográficos, cartográficos e hidro-climatológicos e o trabalho de campo.

\subsubsection{Levantamento Bibliográfico}

O levantamento bibliográfico realizado objetivou, em um primeiro momento, uma revisão bibliográfica de conteúdos de Geomorfologia com ênfase em Geomorfologia Fluvial, Cartografia Geomorfológica, Sedimentologia Fluvial, Pedologia e Hidrologia. Para este levantamento foram utilizadas as referências disponíveis (livros, teses, revistas, periódicos, artigos e manuais) na biblioteca da Faculdade de Filosofia Letras e Ciências Humanas FFLCH, na biblioteca do Instituto de Geociências - IGc USP e na biblioteca do Laboratório de Geomorfologia - GEOMORFOLAB, do Departamento de Geografia da USP.

Em seguida foi realizado levantamento e seleção de referências (dados secundários), buscando uma abordagem mais regional para caracterização da Bacia Hidrográfica do rio Negro, com pesquisa voltada para o trecho do Arquipélago de Anavilhanas, do conhecimento disponível de Geologia, Geomorfologia, Hidrologia, Ecologia, Pedologia, Climatologia e de Vegetação. Estes levantamentos e aquisições foram realizados nos respectivos órgãos e nos sites destes, como o Serviço Geológico do Brasil - CPRM, Instituto Brasileiro de Geografia e Estatística - IBGE, Agência Nacional de Águas - ANA, Instituto de Pesquisas da Amazônia INPA, Departamento Nacional da Produção Mineral - DNPM, Instituto Chico Mendes de Biodiversidade- ICMBio, Empresa Brasileira de Pesquisa Agropecuária - EMBRAPA, além de consultas à internet de sites de revistas, periódicos e entidades de pesquisas nacionais e internacionais.

\subsubsection{Levantamento Cartográfico}

O levantamento da Cartografia disponível foi realizado junto ao Serviço Geológico do Brasil - CPRM, Departamento Nacional da Produção Mineral - DNPM; Instituto Brasileiro de Geografia e Estatística - IBGE e Diretoria de Levantamento Cartográfico - DSG, 4 DLDivisão de Levantamento com sede em Manaus-AM. As fotografias aéreas foram cedidas pela CPRM e a $4^{\text {a }}$ DL disponibilizou o material em meio digital, formato PDF. 
As fotografias aéreas foram utilizadas para a elaboração da carta geomorfológica de detalhe (1:100.000), cujo trabalho de fotointerpretação, executado em 2011, teve como objetivo identificar, localizar e dimensionar as unidades da morfologia fluvial e suas características na área estudada.

\subsubsection{Levantamento de dados Hidrológicos}

Os dados hidrológicos da Bacia Hidrográfica do rio Negro foram obtidos a partir do site da Agência Nacional de Águas - ANA, Serviço Geológico do Brasil - CPRM, do Sistema de Proteção da Amazônia - SIPAM. Os dados de cotas do Rio Negro medidos em Manaus foram obtidos diretamente do Porto de Manaus que os disponibiliza desde 1902 em seu site: http://www.portodemanaus.com.br.

Para análise da variabilidade sazonal das cotas do rio Negro foram utilizados dados de cota das estações de São Gabriel da Cachoeira - 14320001, Tapuruquara - 14400000, Barcelos - 14480002, Moura - 14840000 e Manaus - 14990000.

O comportamento anual das vazões do rio Negro foi analisado utilizando-se os dados disponíveis para as estações de Cucuí - 14110000, São Felipe - 14250000, Curicuriari 14330000 ambas localizadas no município de São Gabriel da Cachoeira; a estação de Serrinha - 14420000, no município de Santa Izabel do Rio Negro e a estação de Paricatuba 14990000 em Manaus. Todas as estações selecionadas estão em operação e possuem dados com série histórica de 30 anos. Entretanto, para a estação de Paricatuba os dados disponíveis estão restritos aos anos de 2006, 2007, 2008, 2009, 2010 e 2011 e, ainda, estão incompletos em relação ao ano hidrológico.

Nos relatórios anuais de cheias e vazantes do rio Negro em Manaus a CPRM disponibiliza dados de velocidade de fluxo do rio medidas na estação de Paricatuba 14990000, para os anos de 2006 a 2011. Foram estes os dados utilizados nesta pesquisa para interpretações quanto ao comportamento anual das vazões, auxiliando em interpretar tendências espaciais e temporais dos processos de erosão e deposicionais do rio Negro na área de estudo. 
Quadro 3: Material Cartográfico disponibilizado

\begin{tabular}{|c|c|c|c|c|c|}
\hline MATERIAL & $\begin{array}{l}\text { DATA } \\
\end{array}$ & LEVANTAMENTO & ESCALA & FONTE & REFERÊNCIA \\
\hline $\begin{array}{l}\text { Fotografias } \\
\text { Aéreas }\end{array}$ & 1976 & FAB/DSG & $1: 100.000$ & $\begin{array}{l}\text { Serviço Geológico } \\
\text { do Brasil - CPRM }\end{array}$ & $\begin{array}{l}350013-350015 \\
360013-360017 \\
370012-370017 \\
380010-380013 \\
390009-390013 \\
400006-400012\end{array}$ \\
\hline $\begin{array}{l}\text { Carta } \\
\text { Topográfica }\end{array}$ & 1983 & $\begin{array}{l}\text { Ministério do } \\
\text { Exército/DSG }\end{array}$ & $1: 250.000$ & $4^{\mathrm{a}}$ DL Manaus-AM & $\begin{array}{c}\text { Folha SA.20-Z-B-V } \\
\text { MIR-94 } \\
\text { Novo Airão-AM }\end{array}$ \\
\hline $\begin{array}{l}\text { Carta } \\
\text { Topográfica }\end{array}$ & 1980 & $\begin{array}{l}\text { Ministério do } \\
\text { Exército/DSG }\end{array}$ & $1: 100.000$ & $4^{\mathrm{a}}$ DL Manaus-AM & $\begin{array}{c}\text { Folha SA.20-Z-B-V } \\
\text { MIR-516 } \\
\text { Novo Airão-AM }\end{array}$ \\
\hline $\begin{array}{l}\text { Mosaicos semi- } \\
\text { controlados }\end{array}$ & 1983 & $\begin{array}{l}\text { Ministério do } \\
\text { Exército/DSG }\end{array}$ & $1: 250.000$ & $4^{\mathrm{a}}$ DL Manaus-AM & $\begin{array}{l}\text { Folha SA.20-Z-B } \\
\text { Novo Airão-AM }\end{array}$ \\
\hline $\begin{array}{l}\text { Cartas } \\
\text { Temáticas } \\
\text { (geologia, } \\
\text { geomorfologia, } \\
\text { pedologia) }\end{array}$ & $\begin{array}{l}1978 \\
2010\end{array}$ & $\begin{array}{l}\text { DNPM } \\
\text { IBGE }\end{array}$ & $\begin{array}{l}1: 1.000 .000 \\
1: 1.800 .000\end{array}$ & $\begin{array}{l}\text { RADAMBRASIL } \\
\text { IBGE }\end{array}$ & $\begin{array}{c}\text { Folha SA.20 } \\
\text { Manaus-AM } \\
\text { Estado do } \\
\text { Amazonas }\end{array}$ \\
\hline $\begin{array}{l}\text { Imagens de } \\
\text { Satélite }\end{array}$ & 2010 & Satélite LISS 3 & $1: 250.000$ & INPE & \\
\hline
\end{tabular}

Os dados pluviométricos utilizados compreenderam os disponibilizados para as estações pluviométricas de São Felipe - 8067001, Tapuruquara - 65001, Moura - 161002, Novo Airão - 260006 e Manaus - 82331, esta última os dados foram obtidos do Instituto de Nacional de Meteorologia - INMET.

\subsubsection{Levantamento de Campo}

As etapas de campo realizadas objetivaram o reconhecimento da área, reconhecimento das morfologias levantadas na fotointerpretação, descrição e caracterização da morfologia das ilhas, descrição das estruturas sedimentares fluviais, levantamento de dados morfométricos das formas, descrição de perfis sedimentares, tradagem e coleta de amostras dos materiais 
superficiais para análise granulométrica. Em junho de 2012, época de cheia do rio Negro, foi realizada etapa de campo para observação das cotas do rio em Anavilhanas, comparação destas com os níveis registrados na vazante e análise da dinâmica fluvial no período (Figura 19).

Para a realização das etapas de campo, os seguintes materiais e métodos foram adotados:

a) Acesso e deslocamento na área: para o acesso as ilhas, paranás, furos, lagos e igarapés utilizou-se uma pequena embarcação a motor, com capacidade para 06 pessoas, alugada no município de Novo Airão. Para os trabalhos realizados próximo a cidade de Manaus a embarcação foi alugada nesta;

b) Reconhecimento das morfologias mapeadas e checagem de campo: uso das Fotografias Aéreas, Carta Topográfica, GPS eTrex legend® $\mathrm{HCx}$ para georreferenciamento dos pontos levantados, Câmera Digital Cyber-shot 14.1 MP Sony® e Caderneta de campo;

c) Levantamento de dados morfológicos: Trena de 50metros, Bússola de Geólogo Brunton® e Clinômetro;

d) Tradagem: nesta etapa foi utilizado Trado tipo Holandês e feita coleta sistemática de amostras; foram utilizados sacos plásticos de 1 litro para coleta das amostras;

e) Abertura de Trincheiras, perfis e caracterização dos materiais (rochas e sedimentos): o material utilizado nesta etapa compreendeu martelo geológico, pá, enxada, picareta, sacos plásticos para acondicionamento de amostras, trena, fita adesiva e canetas permanentes e etiquetas para identificação das amostras. Os materiais foram caracterizados morfologicamente (cor, estrutura, textura, pegajosidade, cerosidade e consistência), definidos a sua espessura e realizada coleta sistemática de amostras. Para caracterização da cor foi utilizada a Tabela de cores Munsell® Soil Color Charts (1994).

f) Identificação da cobertura vegetal: coleta de material para posterior identificação e registro fotográfico das espécies vegetais.

Para a realização desta etapa foi solicitada do Instituto Chico Mendes de Conservação da Biodiversidade - ICMBio autorização para atividades com finalidade científica, número 30431-1, emitida em 27/09/2011. Em todos os levantamentos de campo realizados foi feito o 
georreferenciamento do local com o uso de GPS, registro fotográfico e descrição dos materiais, estruturas sedimentares e morfológicas em caderneta de campo (Figura 20).
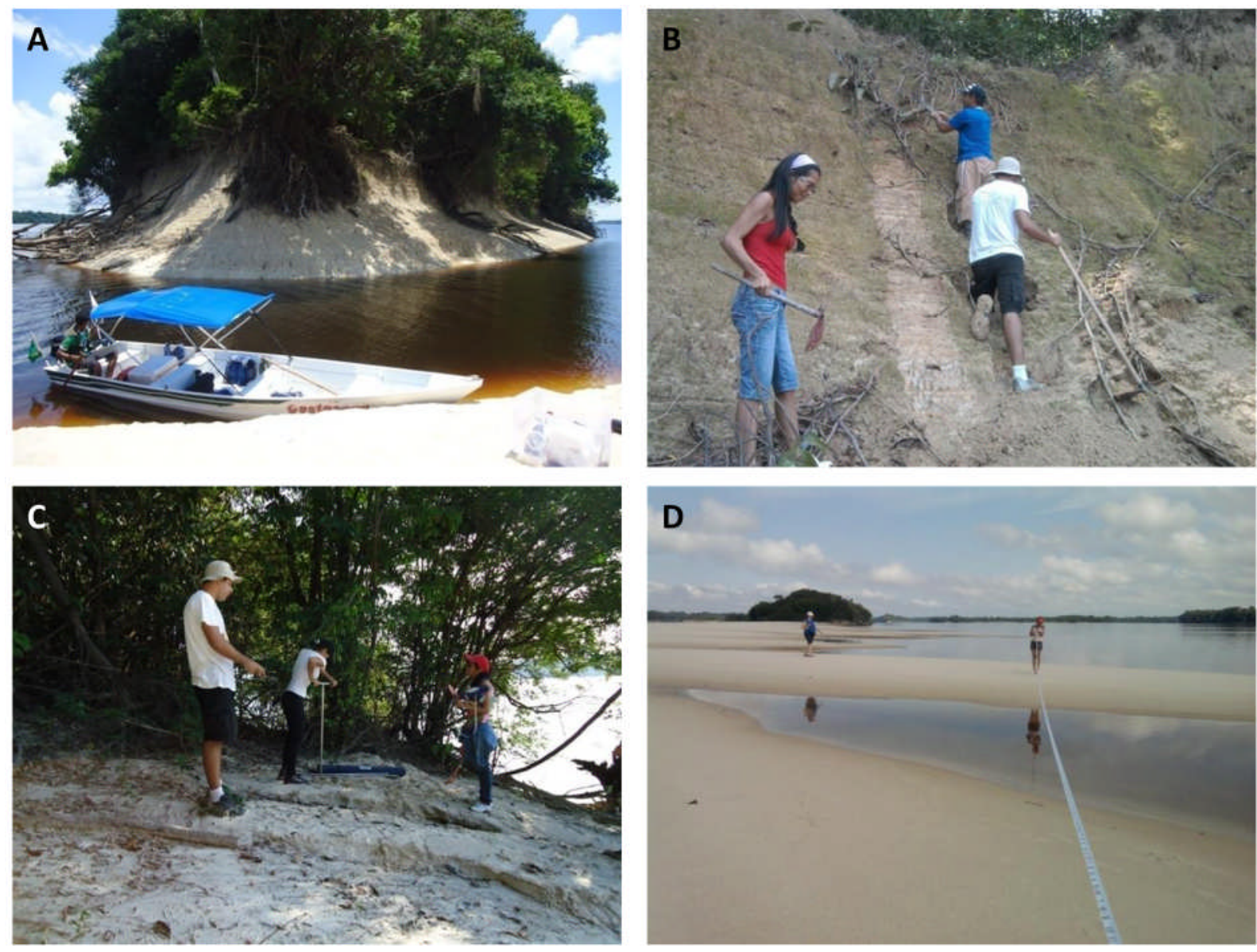

Figura 19: A: Embarcação utilizada nos trabalhos de campo; B: Preparação dos perfis; C: Tradagem; D: Levantamento de dados morfométricos. (imagens da autora, 2011) 


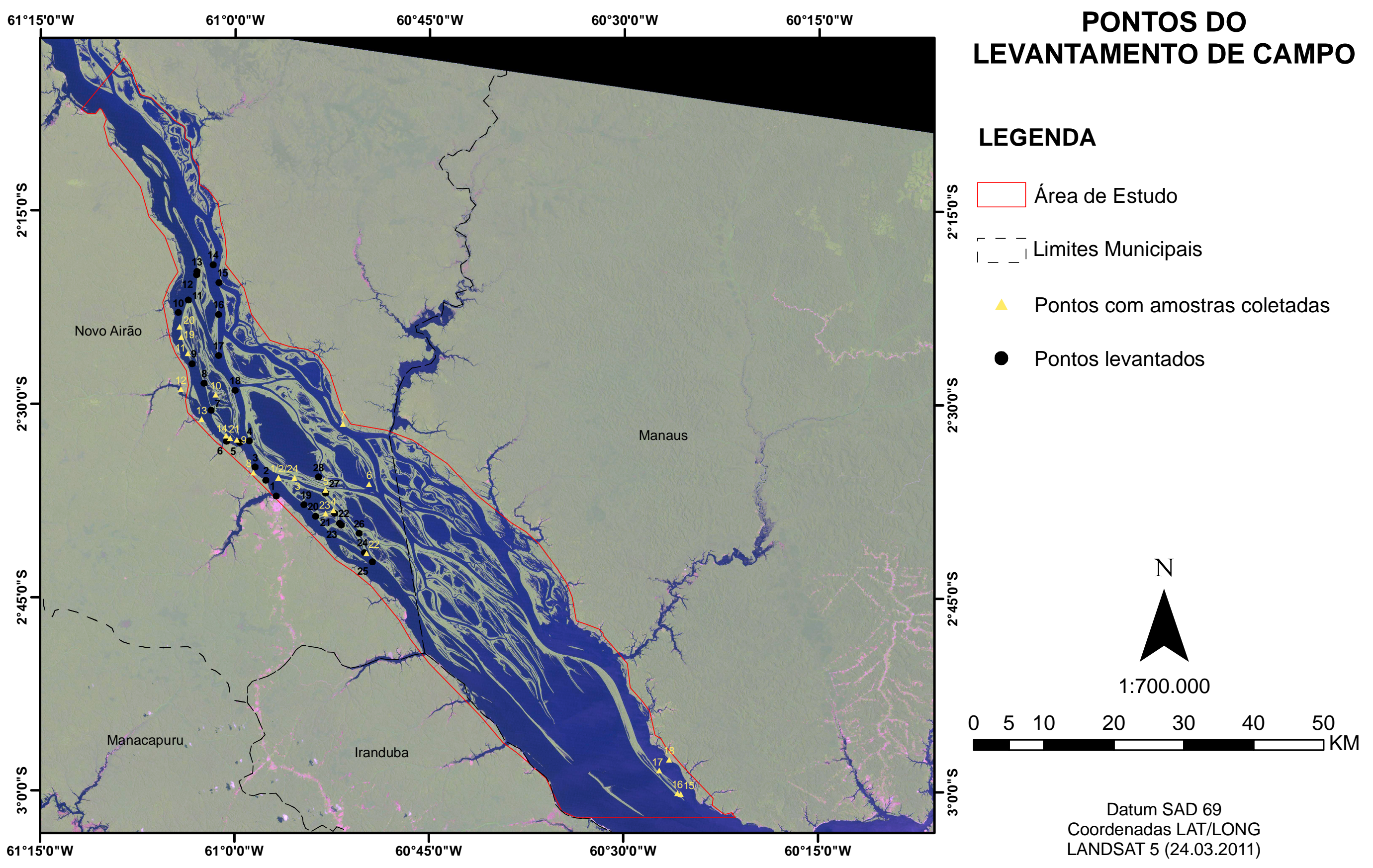

Figura 20: Mapa de localização ds pontos levantados e amostrados em campo 


\subsubsection{Sistematizações e análises}

Esta etapa dos trabalhos envolveu trabalhos de laboratório, gabinete e uso de computadores e de recursos de informática como softwares para confecção de mapas, elaboração de tabelas, perfis e gráficos.

\subsubsection{Atividades de Laboratório}

O material amostrado nos perfis, nas tradagens e nos diversos ambientes mapeados nas etapas de campo, totalizaram 54 amostras (Quadros 4 e 5), sendo analisados no Laboratório de Solos - LATOSSOLO da Universidade Federal do Amazonas - UFAM.

Os materiais superficiais foram identificados e descritos inicialmente em campo quanto à sua morfologia, isto é, foi realizado um estudo da sua aparência no meio ambiente natural e sua descrição segundo as características perceptíveis, visíveis a olho nu ou sensíveis ao tato. As principais características morfológicas descritas incluíram a cor, textura, estrutura, consistência, porosidade, atividade biológica e por fim os horizontes diferenciados por estas características e espessura dos mesmos.

As análises granulométricas foram realizadas adotando-se o Método da Pipeta, de acordo com o Manual de Métodos e Análise de Solo (1997) da EMBRAPA - Empresa Brasileira de Pesquisa Agropecuária, cujo princípio baseia-se na velocidade de queda das partículas que compõem o solo. Fixa-se o tempo para o deslocamento vertical na suspensão do solo com água, após a adição de dispersante químico $(\mathrm{NaOH})$. Pipeta-se um volume da suspensão, para determinação da argila que seca em estufa é pesada. A fração argila é determinada por densimetria no sobrenadante. As frações grosseiras (areia fina e grossa) são separadas por tamisação, secas em estufa e pesadas para obtenção dos respectivos percentuais. O silte corresponde ao complemento dos percentuais para 100\%. É obtido por diferença das outras frações em relação à amostra original.

Os procedimentos adotados, cálculos, reagentes e equipamentos utilizados encontramse detalhados no referido manual (EMBRAPA, 1997, p.27-32). 
Quadro 4: Localização dos pontos de observação e amostragem e número de amostras coletadas

\begin{tabular}{|c|c|c|c|c|}
\hline $\begin{array}{c}\text { Pontos de } \\
\text { observação }\end{array}$ & $\begin{array}{c}\text { Coordenadas } \\
\text { Geográficas do ponto }\end{array}$ & Amostras coletadas & Unidade morfológica & Ambiente \\
\hline 01 & $\begin{array}{l}\text { Lat. } 02^{\circ} 35^{\prime} 44,7^{\prime \prime} \\
\text { Long. } 60^{\circ} 56^{\prime} 39,7^{\prime \prime}\end{array}$ & $\overline{\text { ANA_1 }}$ & $\begin{array}{l}\text { Canal - Barra fluvial } \\
\text { central }\end{array}$ & Fluvial \\
\hline 02 & $\begin{array}{l}\text { Lat. } 02^{\circ} 35^{\prime} 44,7^{\prime \prime} \\
\text { Long. } 60^{\circ} 56^{\prime} 39,7^{\prime \prime}\end{array}$ & ANA_2 & $\begin{array}{l}\text { Planície de inundação - } \\
\text { Promontório }\end{array}$ & Insular \\
\hline 03 & $\begin{array}{l}\text { Lat. } 02^{\circ} 35^{\prime} 43,1^{\prime \prime} \\
\text { Long. } 60^{\circ} 55^{\prime} 24,9^{\prime \prime}\end{array}$ & ANA_3, ANA_4 & $\begin{array}{l}\text { Planície de inundação - } \\
\text { Lago }\end{array}$ & Lacustre \\
\hline 04 & $\begin{array}{l}\text { Lat. } 02^{\circ} 38^{\prime} 13,5^{\prime \prime} \\
\text { Long. } 60^{\circ} 52^{\prime} 24,1^{\prime \prime}\end{array}$ & ANA_5, ANA_6 & $\begin{array}{l}\text { Planície de inundação - } \\
\text { Lago }\end{array}$ & Lacustre \\
\hline 05 & $\begin{array}{l}\text { Lat. } 02^{\circ} 36^{\prime} 39,0^{\prime \prime} \\
\text { Long. } 60^{\circ} 53^{\prime} 01,7^{\prime \prime}\end{array}$ & ANA_7 & $\begin{array}{l}\text { Planície de inundação - } \\
\text { Dique longitudinal }\end{array}$ & Insular \\
\hline 06 & $\begin{array}{l}\text { Lat. } 02^{\circ} 36^{\prime} 11,3^{\prime \prime} \\
\text { Long. } 60^{\circ} 49^{\prime} 39,7^{\prime \prime}\end{array}$ & ANA_8 & $\begin{array}{l}\text { Planície de inundação - } \\
\text { Lago }\end{array}$ & Lacustre \\
\hline 07 & $\begin{array}{l}\text { Lat. } 02^{\circ} 31^{\prime} 32,3 \prime \prime \\
\text { Long. } 60^{\circ} 51^{\prime} 42,1^{\prime \prime}\end{array}$ & $\begin{array}{l}\text { ANA_9, ANA_10, } \\
\text { ANA_11, ANA_12 }\end{array}$ & Terra Firme & $\begin{array}{l}\text { Vertentes } \\
\text { vale }\end{array}$ \\
\hline 08 & $\begin{array}{l}\text { Lat. } 02^{\circ} 35^{\prime} 18,6^{\prime \prime} \\
\text { Long. } 60^{\circ} 58^{\prime} 36,1^{\prime \prime}\end{array}$ & ANA_13 & $\begin{array}{l}\text { Canal - Barra fluvial } \\
\text { lateral }\end{array}$ & Fluvial \\
\hline 09 & $\begin{array}{l}\text { Lat. } 02^{\circ} 32^{\prime} 46,6^{\prime \prime} \\
\text { Long. } 60^{\circ} 59^{\prime} 51,8^{\prime \prime}\end{array}$ & ANA_14 & $\begin{array}{l}\text { Canal - Barra fluvial } \\
\text { central }\end{array}$ & Fluvial \\
\hline 10 & $\begin{array}{l}\text { Lat. } 02^{\circ} 29^{\prime} 16,1^{\prime \prime} \\
\text { Long. } 61^{\circ} 01^{\prime} 30,7^{\prime \prime}\end{array}$ & ANA_15, ANA_16 & $\begin{array}{l}\text { Planície de inundação - } \\
\text { Lago }\end{array}$ & Lacustre \\
\hline 11 & $\begin{array}{l}\text { Lat. } 02^{\circ} 26^{\prime} 03,3^{\prime \prime} \\
\text { Long. } 61^{\circ} 03,39,6^{\prime \prime}\end{array}$ & ANA_17 & $\begin{array}{l}\text { Canal - Barra fluvial } \\
\text { central }\end{array}$ & Fluvial \\
\hline 12 & $\begin{array}{l}\text { Lat. } 02^{\circ} 28^{\prime} 51,9^{\prime \prime} \\
\text { Long. } 61^{\circ} 04^{\prime} 11,8^{\prime \prime}\end{array}$ & ANA_18 & Terra Firme & $\begin{array}{l}\text { Vertentes } \\
\text { vale }\end{array}$ \\
\hline 13 & $\begin{array}{l}\text { Lat. } 02^{\circ} 31^{\prime} 11,5^{\prime \prime} \\
\text { Long. } 61^{\circ} 02 \text { ' } 35,3^{\prime \prime}\end{array}$ & ANA_19, ANA_20 & Terra Firme & $\begin{array}{l}\text { Vertentes } \\
\text { vale }\end{array}$ \\
\hline 14 & $\begin{array}{l}\text { Lat. } 02^{\circ} 32^{\prime} 28,9^{\prime \prime} \\
\text { Long. } 61^{\circ} 00^{\prime} 43,0^{\prime \prime}\end{array}$ & ANA_21 & $\begin{array}{l}\text { Planície de inundação - } \\
\text { Dique longitudinal }\end{array}$ & Insular \\
\hline 15 & $\begin{array}{l}\text { Lat. } 03^{\circ} 00^{\prime} 11,3^{\prime \prime} \\
\text { Long. } 60^{\circ} 25^{\prime} 34,7^{\prime \prime}\end{array}$ & ANA_21 & $\begin{array}{l}\text { Planície de inundação - } \\
\text { Ilha }\end{array}$ & Insular \\
\hline 16 & $\begin{array}{l}\text { Lat. } 03^{\circ} 00^{\prime} 07,4^{\prime \prime} \\
\text { Long. } 60^{\circ} 25,51,3^{\prime \prime}\end{array}$ & ANA_22 & $\begin{array}{l}\text { Planície de inundação - } \\
\text { Dique longitudinal }\end{array}$ & Insular \\
\hline 17 & $\begin{array}{l}\text { Lat. } 02^{\circ} 58^{\prime} 22,7^{\prime \prime} \\
\text { Long. } 60^{\circ} 27^{\prime} 15,9^{\prime \prime}\end{array}$ & ANA_23, ANA_24 & $\begin{array}{l}\text { Planície de inundação - } \\
\text { Dique longitudinal }\end{array}$ & Insular \\
\hline 18 & $\begin{array}{l}\text { Lat. } 02^{\circ} 57^{\prime} 30,5^{\prime \prime} \\
\text { Long. } 60^{\circ} 26^{\prime} 28,8^{\prime \prime}\end{array}$ & ANA_25 & $\begin{array}{l}\text { Canal - Barra fluvial } \\
\text { lateral }\end{array}$ & Fluvial \\
\hline 19 & $\begin{array}{l}\text { Lat. } 02^{\circ} 24^{\prime} 00,3^{\prime \prime} \\
\text { Long. } 61^{\circ} 04^{\prime} 17,4^{\prime \prime}\end{array}$ & ANA_28 & $\begin{array}{l}\text { Canal - Barra fluvial } \\
\text { central }\end{array}$ & Fluvial \\
\hline 20 & $\begin{array}{l}\text { Lat. } 02^{\circ} 24^{\prime} 47,8^{\prime \prime} ; \\
\text { Long. } 61^{\circ} 04^{\prime} 09,0^{\prime \prime}\end{array}$ & $\begin{array}{l}\text { ANA_27a, ANA_27b, } \\
\text { ANA_27c }\end{array}$ & $\begin{array}{l}\text { Planície de inundação - } \\
\text { Dique longitudinal }\end{array}$ & Insular \\
\hline
\end{tabular}


Quadro 5: Localização dos perfis realizados e número de amostras coletadas

\begin{tabular}{|c|c|c|c|c|c|}
\hline $\begin{array}{c}\text { Pontos de } \\
\text { Observação }\end{array}$ & Perfil & $\begin{array}{l}\text { Coordenadas } \\
\text { geográficas }\end{array}$ & Amostras coletadas & $\begin{array}{c}\text { Unidade } \\
\text { morfológica }\end{array}$ & Ambiente \\
\hline 21 & Perfil 1 & $\begin{array}{l}\text { Lat. } 02^{\circ} 32^{\prime} 39,3^{\prime \prime} \\
\text { Long. } 61^{\circ} 00^{\prime} 22,7^{\prime \prime}\end{array}$ & $\begin{array}{ll}\text { ANA_26a, } & \text { ANA_26b, } \\
\text { ANA_26c, } & \text { ANA_26d, } \\
\text { ANA_26e, } & \text { ANA_26f, } \\
\text { ANA_26g } & \end{array}$ & $\begin{array}{l}\text { Planície de } \\
\text { inundação - Ilha }\end{array}$ & Insular \\
\hline 22 & Perfil 2 & $\begin{array}{l}\text { Lat. } 02^{\circ} 41^{\prime} 33,2^{\prime \prime} \\
\text { Long. } 60^{\circ} 49^{\prime} 51,4 "\end{array}$ & $\begin{array}{l}\text { ANA_29a, ANA_29b, } \\
\text { ANA_29c, } \\
\text { ANA_29d, } \\
\text { ANA_29e, ANA_29f }\end{array}$ & $\begin{array}{l}\text { Planície de } \\
\text { inundação - Ilha }\end{array}$ & Insular \\
\hline 23 & Perfil 3 & $\begin{array}{l}\text { Lat. } 02^{\circ} 38^{\prime} 29,5^{\prime \prime} \\
\text { Long. } 60^{\circ} 53^{\prime} 00,6^{\prime \prime}\end{array}$ & $\begin{array}{ll}\text { ANA_30a, } & \text { ANA_30b, } \\
\text { ANA_30c, } & \text { ANA_30d, } \\
\text { ANA_30e } & \\
\end{array}$ & $\begin{array}{l}\text { Planície de } \\
\text { inundação - Ilha }\end{array}$ & Insular \\
\hline 24 & Perfil 4 & $\begin{array}{l}\text { Lat. } 02^{\circ} 35^{\prime} 44,3^{\prime \prime} \\
\text { Long. } 60^{\circ} 56^{\prime} 38,8^{\prime \prime}\end{array}$ & $\begin{array}{l}\text { ANA_31a, } \\
\text { ANA-31b, } \\
\text { ANA_31c, } \\
\text { ANA_31d, } \\
\text { ANA_31e, ANA_31f }\end{array}$ & $\begin{array}{l}\text { Planície de } \\
\text { inundação - Ilha }\end{array}$ & Insular \\
\hline
\end{tabular}

Para a classificação das classes texturais dos materiais foi adotada a escala granulométrica de Wentworth (1922) apresentada na tabela 1, cujos limites de suas classes são determinados em termos de propriedades físicas envolvidas no transporte de grãos. Os limites de classes, nesta escala, longe de serem arbitrários, concordam perfeitamente com limites de distinções entre cargas transportadas em suspensão e por tração.

Tabela 1 - Escala granulométrica de Wentworth (1922)

\begin{tabular}{cc}
\hline Fração & Diâmetro $\mathbf{( m m})$ \\
\hline Argila & $<0,004$ \\
Silte & $0,062-0,004$ \\
Areia muito fina & $0,125-0,062$ \\
Areia fina & $0,250-0,125$ \\
Areia média & $0,50-0,250$ \\
Areia grossa & $1,0-0,50$ \\
Areia muito grossa & $2,0-1,0$ \\
Grânulo & $4,0-2,0$ \\
\hline
\end{tabular}

Após a determinação da distribuição granulométrica das partículas sedimentares em classes texturais de acordo com a escala granulométrica de Wentworth (1922), o percentual de cada classe textural obtida, para cada amostra analisada, foi lançado no diagrama triangular para a Classificação de Sedimentos de Flemming (2000). Os diagramas triangulares baseiamse, como o nome indica, num triângulo, em que cada vértice corresponde a $100 \%$ de uma 
classe textural elementar (por exemplo, areia, silte e argila). O lado oposto do triângulo corresponde a 0\%. O Diagrama Triangular de Flemming classifica sedimentos constituídos por partículas menores de $2 \mathrm{~mm}$ de diâmetro (Figura 21).

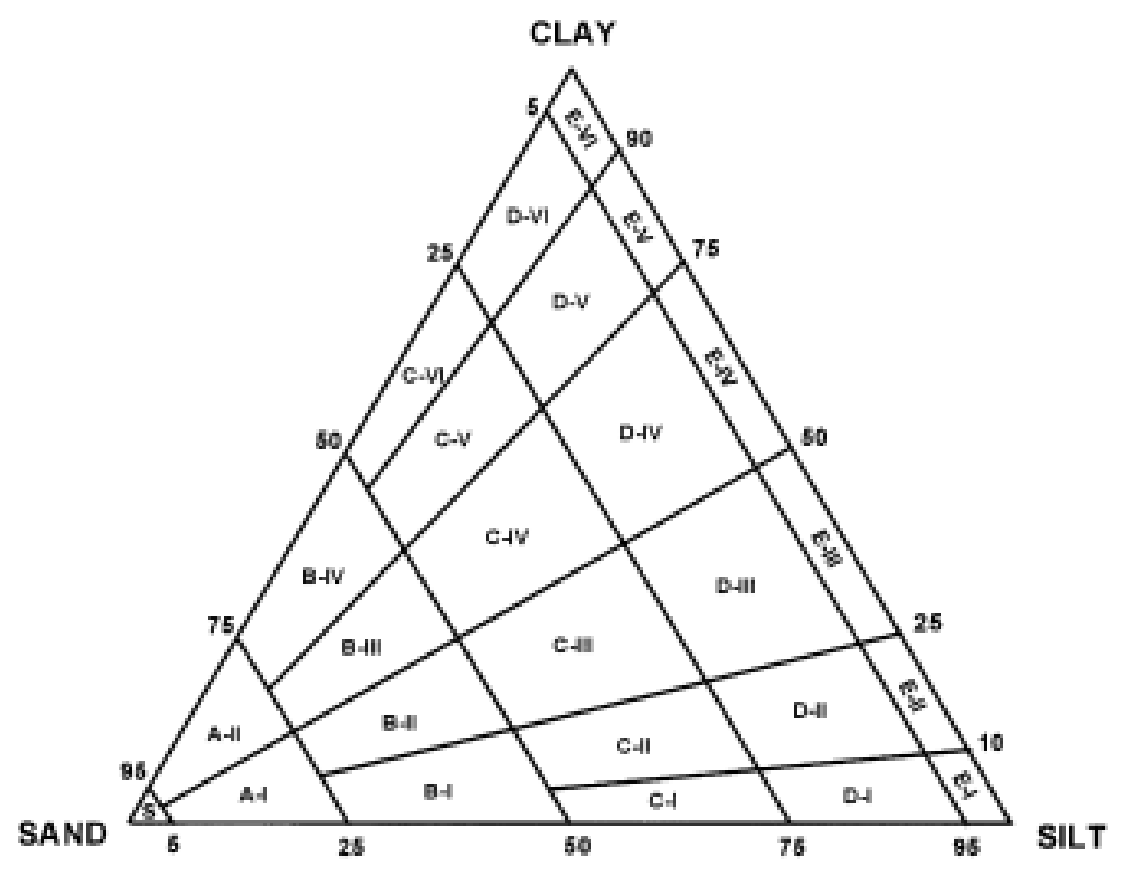

Figura 21: Diagrama Triangular de Flemming (2000)

O diagrama triangular de Flemming considera as proporções entre as frações areia/silte/argila, e trabalha com dois componentes principais: areia e lama (silte e argila). De acordo com a razão areia/lama são definidos seis tipos de sedimentos: Areia (S) com menos 5\% de lama; Areia levemente lamosa (A) com 5-15\% de lama; Areia lamosa (B) com 25$50 \%$ de lama; Lama arenosa (C) com 50-75\% de lama; Lama levemente arenosa (D) com 75-95\% de lama e Lama (E) com mais de 95\% de lama. Em cada caso, o tipo de sedimento (ex: Areia lamosa) pode ser utilizado para tipificar o ambiente deposicional ou fácies com base no critério textural (ex: fácies areia lamosa). De acordo com o modelo hidrodinâmico proposto por Pejrup (1988) apud Flemming (2000), a localização de um conjunto de dados no diagrama ternário reflete condições hidrodinâmicas de energia específica. Quanto mais esse conjunto está localizado próximo ao eixo do silte, maior é o nível de energia; quanto mais próximo do eixo da argila, menor é a energia, sendo o regime mais energético associado ao 
campo (S) da Areia. O diagrama de Flemming subdivide esses seis tipos de sedimentos em 25 classes texturais com base nas razões areia/silte/argila (Quadro 6):

Quadro 6: Tipos de sedimentos e classes texturais de sedimentos lamosos de acordo com a classificação de Flemming (2000)

\begin{tabular}{|c|c|c|c|}
\hline Código & Tipo de Sedimento & $\begin{array}{c}\text { Conteúdo de } \\
\text { lama }(\%)\end{array}$ & Classe Textural \\
\hline $\bar{S}$ & Areia & $<5 \%$ & Areia \\
\hline A-I & Areia levemente lamosa & $5-15 \%$ & Areia levemente siltosa \\
\hline A-II & & & Areia levemente argilosa \\
\hline B-I & & & Areia muito siltosa \\
\hline B-II & Areia lamosa & $25-50 \%$ & Areia siltosa \\
\hline B-III & & & Areia argilosa \\
\hline B-IV & & & Areia muito argilosa \\
\hline C-I & & & Lama arenosa extremamente siltosa \\
\hline C-II & & & Lama arenosa muito siltosa \\
\hline C-III & Lama arenosa & $50-75 \%$ & Lama arenosa siltosa \\
\hline C-IV & & & Lama arenosa argilosa \\
\hline $\mathrm{C}-\mathrm{V}$ & & & Lama arenosa muito argilosa \\
\hline $\mathrm{C}-\mathrm{VI}$ & & & Lama arenosa extremamente argilosa \\
\hline D-I & & & Lama levemente arenosa extremamente siltosa \\
\hline D-II & & & Lama levemente arenosa muito siltosa \\
\hline D-III & Lama levemente arenosa & $75-95 \%$ & Lama levemente arenosa siltosa \\
\hline D-IV & & & Lama levemente arenosa argilosa \\
\hline $\mathrm{D}-\mathrm{V}$ & & & Lama levemente arenosa muito argilosa \\
\hline D-VI & & & Lama levemente arenosa extremamente argilosa \\
\hline E-I & & & Silte \\
\hline E-II & & & Silte levemente argiloso \\
\hline E-III & Lama & $>95 \%$ & Silte argiloso \\
\hline E-IV & & & Argila siltosa \\
\hline E-V & & & Argila levemente siltosa \\
\hline E-VI & & & Argila \\
\hline
\end{tabular}

Para facilitar a distinção entre os tipos de sedimentos e as classes texturais dos materiais classificados, na análise dos dados será adotado nesta pesquisa a proposta de Oliveira, M. A. T. e Lima (2004), ou seja, sempre que houver referência ao tipo de sedimento, sua nomenclatura aparecerá em itálico e com iniciais maiúsculas, por exemplo: Areia Lamosa; quando houver referência às classes texturais, sua nomenclatura aparecerá em itálico e com iniciais minúsculas: lama arenosa muito argilosa. 


\subsubsection{Sistematização}

A sistematização compreendeu a tabulação e o tratamento de todos os dados levantados nas diversas etapas da pesquisa, envolvendo os dados de levantamento de campo (morfométricos, perfis, caracterização morfológica dos materiais superficiais, tradagem), dados cartográficos, dados secundários (bibliográficos), dados pluviométricos e fluviométricos (dados de chuva, cota, vazão e velocidade) e dados de laboratório (análises dos materiais superficiais). Estes dados foram também articulados cartograficamente, sendo que informações morfológicas, sedimentológicas, hidrológicas, assim articuladas, permitiram propor tendências espaciais de processos hidromorfodinâmicos.

O principal produto gerado nesta etapa é a Carta Geomorfológica de detalhe da área, na escala 1:100.000. Para a elaboração desta carta, a sistematização compreendeu a fotointerpretação das fotografias aéreas disponíveis, checagem das formas no campo, vetorização dos overlays, articulação das informações geradas em todas as fases da pesquisa e consequente sistematização da legenda, e edição da carta.

Após a sistematização de todos os dados disponíveis e levantados, foi dado procedimento as análises e interpretação a partir das correlações espaciais dos parâmetros investigados. 


\section{TÓPICOS ESPECIAIS DA REVISÃO BIBLIOGRÁFICA}

\subsection{MORFOGÊNESE DO ARQUIPÉLAGO DE ANAVILHANAS}

Neste item serão apresentadas as diversas propostas existentes na literatura científica acerca do processo de formação do Arquipélago de Anavilhanas. As propostas são diversas e trabalham com hipóteses principalmente baseadas na tectônica. Os estudos considerados são os de Tricart (1977a); Projeto RADAM (1978); Leenheer e Santos (1980); Almeida Filho, Miranda e Beisl (2005); Latrubesse e Franzinelli (2005); Silva, C. L. (2005); Silva, C. L. et al. (2007); Silva, C. L. e Rossetti (2009).

Tricart (1977a) descreve o rio Negro com um vale e um leito "mal calibrados" com duas expansões lacustres, não totalmente colmatadas, ligadas por um vale estreito e com fundo revestido por aluvião. Segundo este autor, o rio Negro, orientado para NW-SE, ocupa, a NW de Manacapuru, uma fossa de afundamento em ângulo de falha, cuja tectônica favoreceu o esvaziamento de uma vasta e profunda depressão, exigindo assim, uma grande quantidade de aluviões para sua colmatagem. Esse modelo é corroborado nos estudos de COSTA, J. B. S. et al. (2008) que descreve para região do baixo Rio Negro uma estruturação definida por falhas normais de direção NW-SE que interagem com falhas maiores E-W, transcorrentes dextrais, resultando no desenvolvimento de bacias romboédricas transtensivas. As falhas mestras normais mergulham para nordeste e controlam a orientação geral do Rio Negro em Anavilhanas. Ainda segundo Tricart (1977a), o rio Branco, afluente do rio Negro, seria o maior responsável pelo fornecimento de sedimentos, visto que este "atacaria" vigorosamente o Neogeno. Coloca que, na vasta superfície líquida, o rio Negro construiu um delta singular, apresentando forma alongada, forma esta comandada pela tectônica, com braços quase paralelos que formariam um feixe, separando-se e reunindo-se à maneira de canais anastomosados. No delta, devido ao déficit aluvial, os diques são baixos e estreitos, e as pequenas bacias são extensas e "permanentemente afogadas". O rio apresentaria, neste trecho, dois canais principais que se localizam ao longo das duas vertentes (Figura 11). O autor sugere, assim, que o trecho anastomosado do rio Negro seria este delta.

Uma das propostas mais antigas relativamente ao processo morfogenético de Anavilhanas é encontrada no Projeto RADAM (1978). Os autores sugerem uma adaptação do rio Negro à estrutura do tipo rift-valley, sem, entretanto, contar com dados geológicos que 
confirmassem, à época deste levantamento, a existência deste rift-valley. Neste modelo, as áreas anastomosadas do Rio Negro ocorreriam nas zonas de rift. A deposição à jusante das ilhas alongadas sugeriria um "entulhamento" contínuo, posteriormente reentalhado por furos. Baseando-se principalmente na análise morfológica de imagens de radar e no conhecimento teórico de geomorfologia fluvial, os autores afirmam que a sedimentação nesse trecho ocorreu através de depósitos lineares fluviais. No caso, a colmatagem teria início em um ponto comum, abrindo-se em dois diques que se juntaram à jusante, deixando no interior zonas vasosas onde se processa uma colmatagem por decantação. Esses diques passariam a funcionar como ilhas, desviando o fluxo da água em vários canais que se encontram à jusante. $\mathrm{Na}$ terminação do arquipélago os diques não deixariam zonas vasosas em seu interior, originando um padrão tipo delta, onde o conjunto se assemelha à "cauda de cometa". Ainda segundo os autores, o posicionamento dos depósitos que constituem as ilhas, em meio ao rio, pode ser explicado pelo fato do rio Negro ter dois talvegues: um encostado em sua margem direita e outro em sua margem esquerda, permitindo que a colmatagem seja mais intensa entre os dois talvegues, resultando no preenchimento e elevação do fundo do leito.

Leenheer e Santos (1980) sugerem que as ilhas de Anavilhanas se formaram a partir da floculação de sedimentos finos oriundos do rio Branco. Para tal conclusão os autores consideraram os seguintes fatores: o rio Negro contém baixa quantidades de sedimentos em suspensão, em concentações próximas de $5 \mathrm{mg} / \mathrm{l}$ de acordo com Meade et al. (1979); o rio Branco, na sua confluência com o rio Negro, deposita concentrações moderadas de sedimentos em suspensão (50 a 300mg/l); as águas do rio Negro são de alto conteúdo orgânico, solúvel e de alta acidez. Com bases nestas argumentações e nas análises químicas detalhadas dos sedimentos e das águas dos rios Branco e Negro, os autores sugerem que o alto conteúdo orgânico solúvel e o baixo $\mathrm{pH}$ do rio Negro, floculou os sedimentos caoliníticos em suspensão adicionados pelo rio Branco, formando complexos caolinita-húmicos para dar origem as "invulgares" (grifo nosso) formas de ilha do arquipélago de Anavilhanas. Estas considerações serão retomadas ao final destas investigação e ideias como a de floculação, à luz de informações reológicas (velocidade de decantação dos sedimentos), poderá ser reconsiderada e reinterpretada.

Do ponto de vista da evolução hidrográfica, ou seja, de uma provável sequência paleohidrográfica, Almeida Filho, Miranda e Beisl (2005) utilzaram dados de elevação digital do terreno obtidos pela Shuttle Radar Topographic Mission (SRTM) para a área do baixo rio 
Negro. Segundo os autores os MDEs gerados demonstraram sinais de um provável paleocurso do rio Negro, representativo de um sistema de drenagem relictual, com fluxo geral para sul com sentido oposto aos cursos dos rios Padauari e Carabinani, pertencentes à bacia do Rio Negro, que fluem para nordeste. Pelo traçado desse paleovale é possível inferir que a confluência dos rios Negro e Solimões localizava-se onde hoje fica a desembocadura do Rio Manacapuru, a cerca de $70 \mathrm{~km}$ a oeste da cidade de Manaus (Figura 22). Esta configuração atual sugeriria a existência de um controle neotectônico sobre a paisagem, como reflexo da instabilidade sísmica da região. Assim, neste estudo, os autores sugerem que o traçado atual do rio Negro na região de Anavilhanas resultaria de uma mega captura fluvial, por efeito de uma neotectônica ativa na região, entretanto, os autores sugerem estudos mais aprofundados de geologia de superfície para que este modelo seja corroborado.

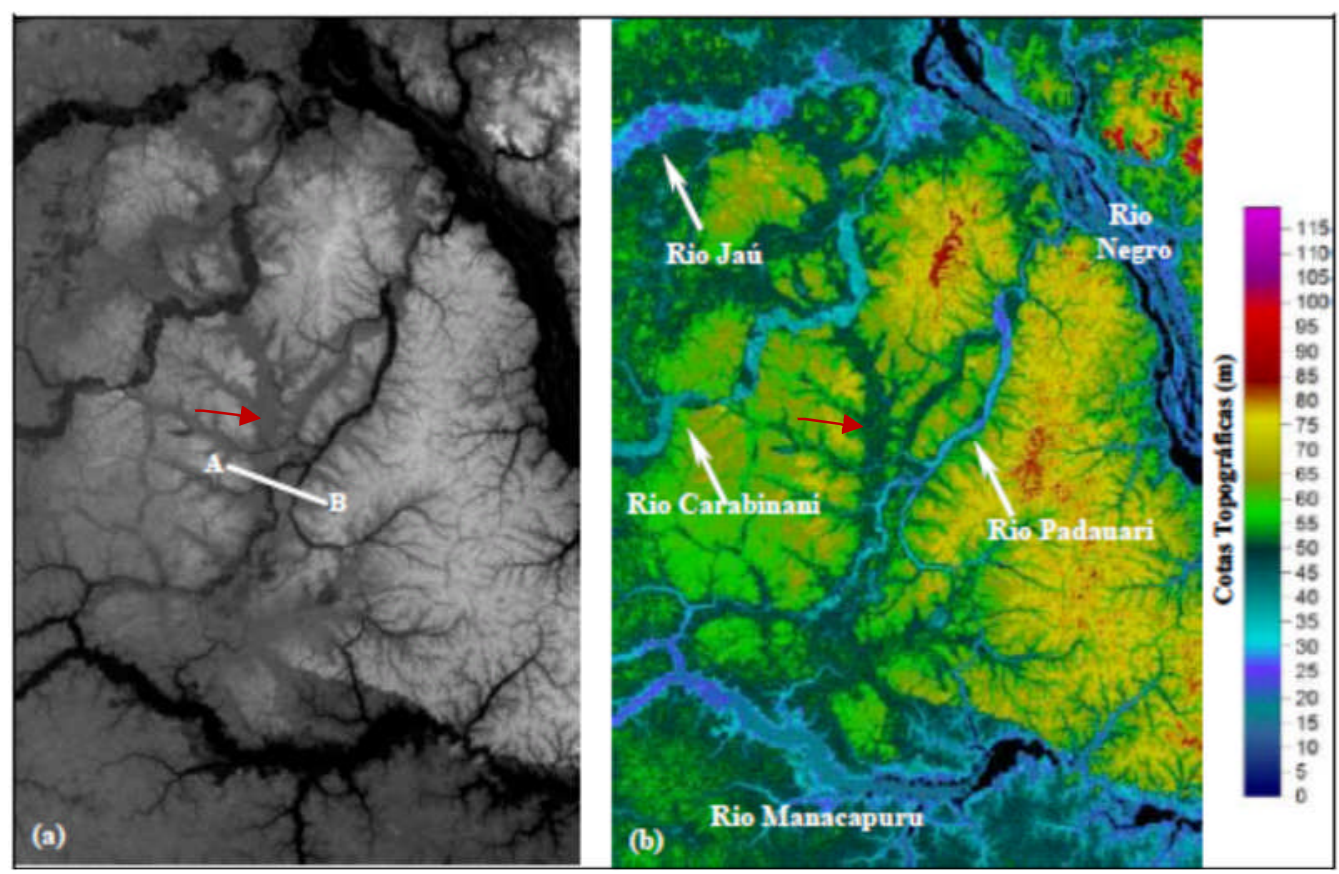

Figura 22: Modelo de elevação digital (SRTM) em (a) e (b) mostrando o antigo paleocanal (indicado pela seta vermelha) entre os rios Padauari e Carabinani, que ligava o rio Negro ao Manacapuru.

Fonte: ALMEIDA FILHO, MIRANDA e BEISL (2005)

Segundo Silva, C. L. (2005), Silva, C. L. et al. (2007), Silva, C. L. e Rossetti (2009) o rio Negro está encaixado em um lineamento NW-SE que tem reflexo na forma do rio e na forma das suas margens escarpadas. Em seu baixo curso, compreende um amplo canal anastomosado com largura de até $20 \mathrm{~km}$, sendo caracterizado por extensos depósitos de barras longitudinais que seriam representadas pelo Arquipélago de Anavilhanas. Desde Novo Airão até próximo a cidade de Manaus, o rio retilíneo flui de NW para SE. Ali estreita-se e desvia 
seu curso na direção E-W, em Paricatuba, para novamente continuar para sudeste até o Rio Solimões e formar o Rio Amazonas. Próximo a Manaus (Figura 10), a inflexão do canal do Rio Negro para leste em um trecho estreito, teria implicações no barramento desse rio, como ampliação do volume de água, diminuição do gradiente e da velocidade e, como consequência, sedimentação em Anavilhanas. De acordo com Silva, C. L. (2005) a falha do rio Negro forma estruturas do tipo grábens (áreas em depressão), que são locais propícios à sedimentação atual. Assim, segundo os autores, o arquipélago de Anavilhanas seria resultante da interrelação entre os processos de sedimentação e fenômenos tectônicos.

O modelo proposto por Latrubesse e Franzinelli (2005) descreve que durante o Holoceno o rio Negro tornou-se gradualmente um vale bloqueado, como resposta do sistema fluvial ao último glacial, com continuidade durante a transgressão do holoceno, do holoceno médio ao holoceno recente. Durante esta transição do Holoceno médio ao recente $(\sim 1000$ anos AP), quatro condições essenciais para a formação do arquipélago de Anavilhanas foram atingidas: a) uma quantidade suficiente de sedimentos em suspensão; b) um ambiente de deposição de baixa energia; c) espaço suficiente no alojamento do vale; e d) aumento no nível de base local. O Arquipélago de Anavilhanas evoluiu como um sistema de acresção vertical de baixa energia com diques limitando um complexo de canais anastomosados, modelo que corrobora com a proposta de Tricart (1977a). O vale teria sido preenchido pela acumulação geral para jusante de um sistema multicanal dominado por processos acrescionais verticais. A morfologia "fantasma" das ilhas, contornadas por diques e normalmente preenchidas com água, é o produto de dois diques estreitos que se estendem vários quilômetros à jusante de uma ilha núcleo à montante, à semelhança da proposta do Projeto RADAM (1978). Estas ilhas seriam o resultado sedimentar da expansão do vale do rio associado com a desaceleração do fluxo à montante (zona estreita), e um aumento do nível base e o seu efeito retroativo produzido pelo barramento dos depósitos aluvial do Solimões-Amazonas quando estes foram depositados como planícies fluviais impedidas (Ilha de Xiborema). O transporte de sedimentos e a formação da planície de inundação ocorreram no último glacial e no Holoceno de 14.000 anos AP a cerca de 1000 anos AP, quando o fornecimento de sedimentos finos em suspensão nas ilhas de Anavilhanas cessou devido ao restabelecimento da cobertura florestal e estabilização da bacia.

Dentre os modelos apresentados, esta pesquisa corrobora com Silva, C. L. (2005), Silva, C. L. et al. (2007), Silva, C.L. e Rossetti (2009) e Latrubesse e Franzinelli (2005), que 
sugerem que o Complexo de Anavilhanas é resultado de processos de sedimentação, em ambiente de baixa energia, associado à tectônica regional. $\mathrm{O}$ efeito de barramento hidráulico exercido no rio Negro pelo sistema Solimões-Amazonas causou o aumento do nível de base provocando condições de redução de velocidade de fluxo e vazão, e consequentemente processos de sedimentação no canal. De acordo com Latrubesse e Franzinelli (2005) estas condições foram atingidas no Holoceno (14.000 anos AP - 1.000 anos AP), que diferem das condições atuais vigentes no sistema cuja dinâmica hidrológica é intensa, porém apresenta dinâmica geomorfológica caracterizada por baixas taxas de erosão e sedimentação.

\subsection{GÊNESE DOS PODZÓIS E SUA INFLUÊNCIA NA CARGA E QUALIDADE DAS ÁGUAS DO RIO NEGRO}

A revisão aqui apresentada sobre a gênese dos podzóis e sua influência na carga e qualidade das águas do rio negro, vem colaborar na interpretação da dinâmica fluvial do rio Negro, na caracterização da composição química do rio Negro e nos processos de sedimentação na área do complexo de Anavilhanas.

Nascimento, N. R. et al. (2004) descrevem para a porção NW da bacia do Rio Negro os podzóis, cuja espessura ultrapassa 10 metros e cuja formação é comumente associada com o desenvolvimento de redução e condições ácidas e a flutuação sazonal do lençol freático. Associam-se a solos com argila de baixa atividade (Ferrossolos e Acrissolos) e são facilmente identificados nos platôs de baixa altitude na bacia sedimentar, tendo sido mapeados pelo Projeto RADAM. Estudos morfológicos, geoquímicos e mineralógicos destes solos têm mostrado que os podzóis podem formar-se a expensas de solos pobres em argilas (Acrissolos) em depressões ou encostas do platô ou relevo tabular e que os dois tipos de solos (Ferrossolos e Acrissolos) podem ser observados na mesma formação geológica (NASCIMENTO, N. R. et al., 2008). Os mecanismos geralmente envolvidos na podzolização do solo são: a) a produção de ácidos orgânicos e minerais intempéricos; b) a formação e translocação de complexos organo-metálicos (predominantemente de $\mathrm{Fe}$ e $\mathrm{Al}$ ); e c) na maioria dos casos, a precipitação de fases inorgânicas de $\mathrm{Fe}, \mathrm{Al}$ e $\mathrm{Si}$ mal cristalizadas. Os podzóis caracterizam-se pela presença de horizontes espódicos em que os compostos orgânicos e o alumínio, com ou sem ferro, ou, ainda outros cátions, foram acumulados. No norte da Bacia Amazônica a baixa elevação do platô ou relevos tabulares segundo o RADAM (1978), a alta pluviosidade, e o 
grande volume de água acumulada nos solos e sedimentos, ajudam a explicar a considerável extensão dos podzóis na região (NASCIMENTO, N. R. et al., 2004; 2008).

Os podzóis cobrem uma área de $200.000 \mathrm{~km}^{2}$ na região de maior precipitação pluvial da Bacia do Alto Amazonas, e 33\% da bacia hidrográfica do Negro. Ocorrem em áreas de depressões abertas drenadas por uma rede difusa de canais e estão lateralmente associados à lateritas amarelas pobres em argila. Nascimento, N. R. et al. (2004) identificaram duas etapas principais para a podzolização destes solos lateríticos. A etapa I marcaria o aparecimento, na margem da depressão, de podzóis menos característicos constituídos por horizontes A orgânico e Bhs (presença de Fe e matéria orgânica). Os compostos orgânicos impregnam profundamente as lateritas pobres em argila, que contêm predominantemente quartzo, mas também caulinita residual, gibbsita e goethita. Os ácidos orgânicos aumentam o intemperismo dos minerais de argila e contribuem para o acúmulo descendente de complexos organometálicos (principalmente $\mathrm{Al}$ e $\mathrm{Fe}$ ). A etapa II marca a perda quase total dos minerais de argila nos horizontes $\mathrm{AE}$ e $\mathrm{E}$ dos podzóis mais característicos e o acúmulo em maiores profundidades de uma segunda geração de complexos organo-metálicos nos horizontes bem diferenciados Bh e 2BCs. Os complexos orgânicos são impregnados a 1,2 m de profundidade em uma camada de arenito residual intemperizado (horizonte $2 \mathrm{BC}$ ) que impede $\mathrm{o}$ desenvolvimento vertical dos podzóis e favorece, por outro lado, sua expansão lateral. Nascimento, N. R. et al. (2008), adicionalmente, vincula à etapa II o desenvolvimento de redução e condições ácidas nas águas subterrâneas que alimentam os canais da depressão durante a estação chuvosa, contribuindo para o aumento da acidez das águas do rio Negro.

Baseando-se em observações de campo em pesquisas anteriores aos estudos de Nascimento, N. R. et al. (2004; 2008), Leenheer (1980), advoga que a drenagem dos podzóis desenvolvidos em depósitos aluviais arenosos seria a fonte das águas pretas. A Água preta seria derivada principalmente dos podzóis superficiais cujo horizonte álbico está apenas a poucos metros de profundidade. Segundo este pesquisador, horizontes álbicos com mais de 3 metros de espessura produzem somente uma pequena quantidade de matéria orgânica que poderia ser degradada em substâncias húmicas. Abaixo do horizonte álbico, um horizonte espódico, rico em material húmico é frequentemente encontrado acima de uma lente de argila, ou acima de material argiloso original que subjaz areias aluviais. Nos podzóis rasos, os materiais húmicos não são absorvidos pela argila subjacente porque os horizontes espódicos, ricos em substâncias húmicas, anteriormente depositados saturaram locais de absorção de 
argila ativa, atuando também como uma barreira hidrológica, evitando infiltração de água preta na argila subjacente, onde pode ocorrer a absorção adicional de substâncias húmicas. Uma espessa camada de serrapilheira orgânica se acumula na superfície do podzóis superficiais. A lenta degradação desta camada de serrapilheira fornece uma fonte contínua de substâncias húmicas solúveis, que são responsáveis pela coloração da água preta do rio Negro.

As águas pretas do Rio Negro transportam uma baixa carga de sedimentos (5-12mg/l), com $\mathrm{Fe}$ presente principalmente na forma de $\mathrm{Fe}^{\mathrm{III}}$ associado a coloides orgânicos, mas também como $\mathrm{Fe}^{2+}$ dissolvido. As águas pretas estão associadas ao desenvolvimento de redução e condições ácidas ( $\mathrm{pH}$ até 3) e a acumulação subsequente de matéria orgânica em solos arenosos alagados. Nesses solos muito degradados, também conhecidos como podzóis, a matéria orgânica desempenha um papel importante no intemperismo dos minerais e de transferência de íons metálicos para os rios (FRITSCH et al., 2009).

Sabe-se que a matéria orgânica do rio Negro origina-se dos podzóis (LEENHEER, 1980; LEENHEER e SANTOS, 1980; NASCIMENTO, N. R. et al. 2004, 2008; SIOLI, 1984), onde a translocação do ferro ocorre em adição à dissolução de silicatos e óxidos de Fe. Allard et al. (2004) demonstraram que nas águas do rio Negro, que transportam uma grande quantidade de matéria orgânica em suspensão, a especiação do Fe é caracterizada por uma forte contribuição de coloides orgânicos e dos mais altos níveis de ferro complexado na matéria orgânica. Estudos geoquímicos das águas associadas à transição dos podzóis/lateritas mostram que é nas lateritas que o Fe é mobilizado como Fe (II), enquanto a matéria orgânica é produzida no podzol (NASCIMENTO, N. R. et al., 2008; FRITSCH et al., 2009).

De acordo com Allard et al. (2011) altas concentrações de ferro são frequentemente encontradas em águas ricas em carbono orgânico, cujas concentrações variam de 4 a $40 \mu \mathrm{mol} / \mathrm{L}$ nos rios. Este fenômeno tem sido associado com a elevada afinidade química da matéria orgânica de se unir ao Fe. As águas pretas do rio Negro são ácidas ( $\mathrm{pH}=4,0-5,6)$ com concentrações de Fe relativamente proeminentes que variam entre 1 e $10 \mu \mathrm{mol} / \mathrm{L}$ que são significativamente superiores à média de $0,7 \mu \mathrm{mol} / \mathrm{L}$. Os sólidos em suspensão das águas do rio Negro contém pequenas quantidades de argilas (principalmente caulinita e óxidos de $\mathrm{Fe}$ ), areias de quartzo residual e restos de plantas. A carga coloidal mostra uma assinatura FTIR (Espectroscopia de Infravermelho com Transformada de Fourier) consistente com a presença 
de substâncias húmicas e semelhante aos horizontes podzóis. O ferro é distribuído igualmente entre as frações coloidais e particuladas nas águas dos podzóis, considerando que é fortemente concentrado na fração particulada nas águas límpidas das lateritas.

No rio Negro, a contribuição de Fe dos podzóis aumenta de jusante (baixo rio Negro) para montante (alto rio Negro) onde se observa um aumento das ocorrências de podzóis nas paisagens à montante da bacia hidrográfica do Negro. A análise dos níveis de ferro trivalente organicamente complexado [FeOM] medidos ao longo do rio Negro entre os municípios de São Gabriel da Cachoeira e Manaus, correspondente a um trecho de cerca de $1000 \mathrm{~km}$, mostrou que as concentrações de FeOM para ambas as frações de matéria coloidal e sobrenadante em suspensão são quase constantes ao longo do percurso total. Assim, nenhuma evolução para a qualidade da matéria em suspensão é evidenciada ao longo do Rio Negro, mostrando uma estabilidade relativa das partículas transportadas como avaliada para o ferro trivalente complexado na matéria orgânica. Por outro lado, o fluxo de $\mathrm{FeOM}$ em $\mu \mathrm{mol} / \mathrm{L}$ mostram que, quantitativamente, há uma tendência crescente a jusante em mais de $1000 \mathrm{~km}$, de acordo com o aumento da descarga e correspondente a $1,5.10^{6}$ para 6,8.10 $\mu \mathrm{mol} / \mathrm{s}$. Assim, uma tendência semelhante é observada para a concentração do ferro trivalente em solução, que está relacionada com a concentração de ferro trivalente complexado (ALLARD et al., 2011).

Allard et al. (2011) estabelecem como fonte principal do Fe, as lateritas hidromórficas e a sua transição com os podzóis, onde ocorre intensa dissolução de óxidos de ferro, como proposto por Nascimento, N. R. et al. (2008). Os podzóis são exauridos em ferro e são a principal fonte da matéria orgânica. Este estudo das frações particuladas e coloidais, usando espectroscopia FTIR e EPR, de várias águas intersticiais de sequencia de solo, igarapés e rios da bacia hidrográfica do rio Negro, permitiu demonstrar que todos os sólidos em suspensão contêm matéria orgânica e ferro trivalente organicamente complexado (FeOM). A concentração de FeOM é um parâmetro útil para diferenciar e revelar fontes e evolução da matéria em suspensão em vários compartimentos naturais da bacia hidrográfica do rio do Negro. Para explicar a correlação entre o Fe(II) em solução e (FeOM), os autores propuseram duas interpretações que não são mutuamente exclusivas: (a) uma progressiva mistura entre os membros finais das águas das lateritas e podzóis e (b) uma progressiva oxidação do Fe(II) das águas dos podzóis hidromórficos para o canal principal. 
Tanto a redução do ferro, operando a partir de um estoque de ferro nas lateritas durante a transição laterita/podzol como a produção de matéria orgânica em podzóis hidromórficos, são processos importantes para a mobilização de ferro orgânico nas águas. A contribuição do $\mathrm{Fe}(\mathrm{II})$ é dominante na água dos podzóis e menor no canal principal. A subsequente oxidação e complexação para a matéria orgânica estão confirmadas como importantes mecanismos para o transporte de ferro na bacia do rio Negro. Além dessas conclusões, os dados espectroscópicos sugerem que não há nenhuma evolução mensurável de colóides ao longo de $1000 \mathrm{~km}$ do curso do rio Negro (ALLARD et al., 2011).

\subsection{REGIMES PLUVIAIS E FLUVIAIS REGIONAIS}

A proposta de uma revisão dos estudos hidrológicos disponíveis para a Bacia Amazônia vem contribuir para o entendimento do regime hidrológico do rio Negro na área de pesquisa.

A Bacia Amazônica é caracterizada por uma importante variabilidade espacial das precipitações. As regiões mais chuvosas (3.000 mm/ano e mais) estão localizadas no delta do Amazonas, próximo ao Oceano Atlântico, expostas à Zona de Convergência Intertropical (ZCIT) ou no noroeste da bacia (Colômbia, Norte da Amazônia Equatoriana, Nordeste do Peru e Noroeste do Brasil). As precipitações são também abundantes proximamente à posição média da Zona de Convergência do Atlântico Sul (ZCAS), estabelecida durante o verão austral do Noroeste da Amazônia para o Atlântico Sul Subtropical. As precipitações diminuem em direção aos trópicos atingindo $2.000 \mathrm{~mm} /$ ano no sudeste do Brasil e menos que $1.500 \mathrm{~mm} / \mathrm{ano}$ na planície Peruana-Boliviana e no Estado de Roraima, que é protegido dos fluxos Atlânticos úmidos pelo escudo Guianense. Geralmente observa-se uma baixa pluviosidade nas regiões altas dos Andes onde menos de 1000 mm/ano é medido ao longo de 3000 metros de altitude. Porém, à baixa altitude nos Andes, uma forte variabilidade espacial é observada com precipitação variando entre 500 e 3000 mm/ano. Esta variabilidade espacial está relacionada à direção leste predominante dos ventos alísios úmidos e à localização das estações no lado de barlavento ou sotavento das montanhas (ESPINOZA et al., 2009).

Filizola et al. (2002), a partir de dados de 850 postos pluviométricos de diferentes países da região Amazônica, estabeleceram a carta de chuvas médias anuais da bacia 
hidrográfica do Solimões-Amazonas para o período de 1970-1996. Definiram, para este período, que a intensidade média de chuva para o conjunto da bacia foi de $2300 \mathrm{~mm}$, sendo a mínima anual de $300 \mathrm{~mm}$ observada nos vales dos Andes orientais da Bolívia e do Peru. As máximas foram registradas sobre as bacias dos rios Negro e Japurá, próximo a fronteira Brasil-Peru-Colômbia e nas zonas do piemonte andino na Bolívia, no Peru e no Equador. De acordo com os autores, a distribuição latitudinal das precipitações mostra uma dispersão assimétrica dos dados, com um valor modal compreendido entre as latitudes de 0 e $5^{\circ}$ Norte, e valores pontuais extremos (6000 mm/ano) observados no piemonte andino entre as latitudes de 10 e $20^{\circ}$ Sul (Figura 23).

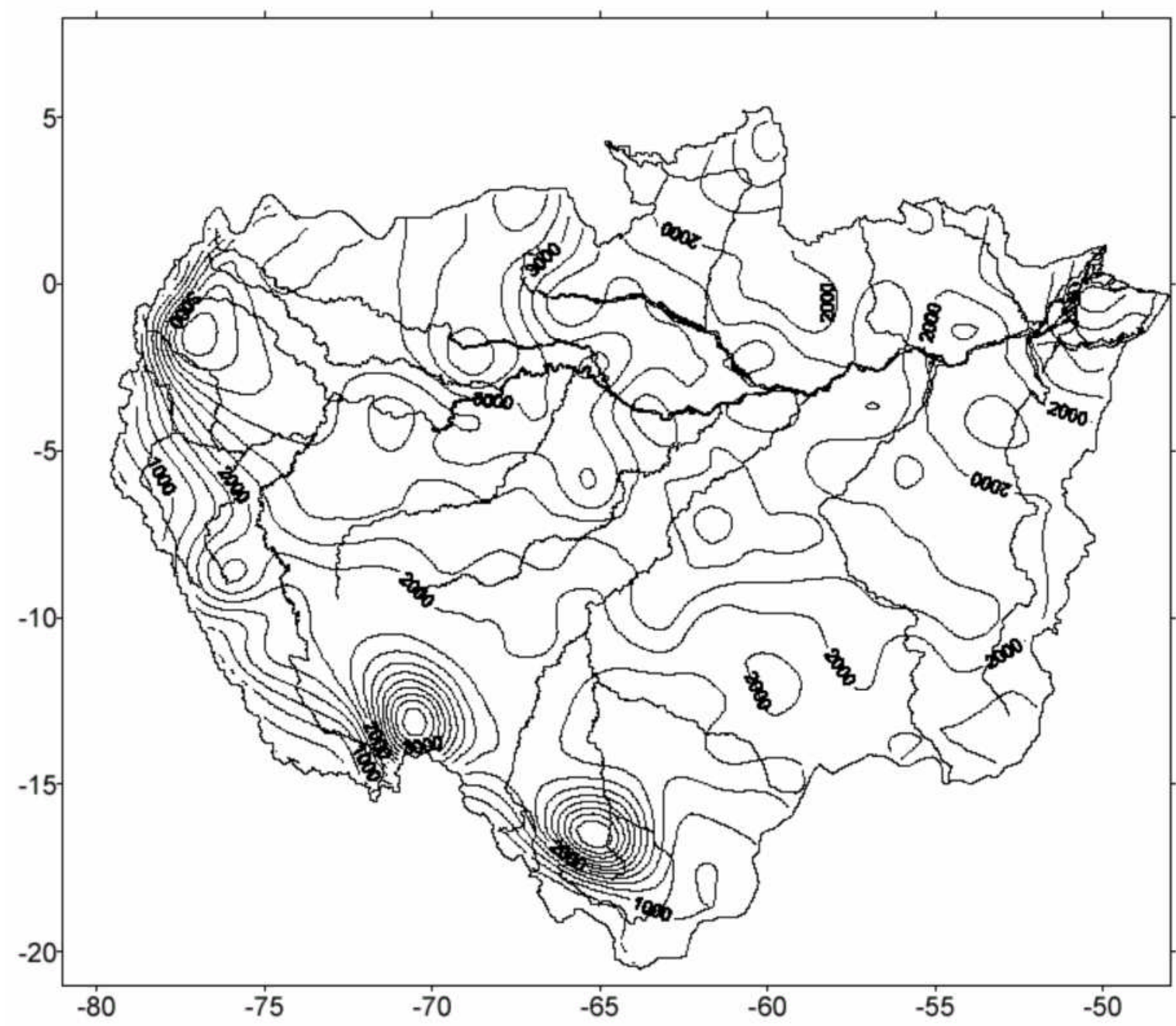

Figura 23: Carta de chuvas médias anuais para a Bacia Amazônica no período de 1970-1996 Fonte: Projeto HIBAM apud FILIZOLA et al. (2002)

Os regimes de precipitação na bacia Amazônica mostram a forte oposição entre os trópicos do norte e do Sul, com uma estação chuvosa em junho, julho e agosto no Norte, e em 
dezembro, Janeiro, fevereiro no Sul, devido ao aquecimento alternado de cada hemisfério e as monções americanas. Nas áreas próximas ao delta do Amazonas, as máximas em março, abril e maio e as mínimas em setembro, outubro, novembro estão associadas com a migração sazonal da Zona de Convergência Intertropical (ZCIT). Na região noroeste equatorial observa-se uma melhor distribuição de chuvas durante o ano com percentuais trimestrais de chuvas perto de $25 \%$ (ESPINOZA et al., 2009).

Os principais rios formadores do Amazonas apresentam características hidrográficas ligadas a três grandes unidades morfoestruturais herdadas da história geológicogeomorfológica da bacia Amazônica: os Escudos, a cordilheira dos Andes e a Planície Amazônica, que ocupam, respectivamente, 44\%, $11 \%$ e $45 \%$ de sua área. Os dois rios de origem andina (rio Marañon-Solimões e rio Madeira) assinam suas contribuições ao Amazonas por águas ricas em material dissolvido e particulado. Na região de Manaus, a convergência das contribuições dos rios Solimões, Negro e Madeira conduzem a um importante aumento das superfícies drenadas e das vazões. Esta concentração de descargas, associada a um declive hidráulico bastante fraco, gera perturbações no escoamento destes rios, agravando as diversas interpretações das curvas-chave nesta região (MEADE et al., 1991; MOLINIER et al.,1994, 1996).

Devido ao seu tamanho, $6.000 .000 \mathrm{~km}^{2}$, e à sua posição em relação ao equador, a bacia hidrográfica do Amazonas abrange diferentes regiões com diversos regimes de descarga. Embora a amplitude média de variação das cotas no sistema Solimões-Amazonas varie em média $10 \mathrm{~m}$ ou mais, durante o ano hidrológico, a descarga varia apenas por um fator de 2 ou 3 vezes mais. Este pequeno intervalo de variação de descarga no canal principal deve-se a dois fatores principais: o primeiro em importância são as grandes diferenças sazonais entre os picos de descarga dos afluentes do Norte e do Sul; e o segundo fator é o armazenamento sazonal de água na planície de inundação. Assim, as contribuições combinadas dos tributários meridionais e setentrionais, de regimes diferentes, associados ao efeito regulador das zonas de inundação (várzeas) gerariam, segundo alguns autores, e à jusante de Manaus, um hidrograma do rio Amazonas de pico único e distribuído de abril a junho (MEADE et al., 1991; MOLINIER et al., 1994; ESPINOZA et al., 2009).

Seguindo a classificação estabelecida por Jean Rodier (1964), Filizola et al. (2002) identificaram 4 tipos de regimes hidrológicos para a bacia do Amazonas: a) o regime tropical 
austral, com um só pico de cheia, normalmente acontecendo no primeiro semestre do ano calendário, representado pelos rios originários do hemisfério sul, como o Purus, Madeira e seus afluentes, Xingu e o Tapajós; b) o regime tropical boreal (rio Branco) com um pico de cheia no segundo semestre do ano; c) o regime equatorial (rios Negro, Içá e Japurá) cujo pico de cheia é mais acentuado no meio do ano, com até dois picos de máxima no ano; d) o regime equatorial alterado representado pelo Solimões e Amazonas, e que sofre a influência dos três regimes citados.

Para estes mesmos autores, a distribuição das vazões específicas ( $\mathrm{Q}$ em 1/s/km²) na bacia Amazônica, apresenta forte tendência regional definindo 4 regiões com vazões específicas médias variando de 5 a $90 \mathrm{l} / \mathrm{s} / \mathrm{km}^{2}$. A zona 1 que abrange a bacia do rio Negro, com vazões específicas variando entre 50 e $90 \mathrm{l} / \mathrm{s} / \mathrm{km}^{2}$; a zona $2 \mathrm{~N}$ (norte) que contempla os afluentes da margem esquerda do rio Amazonas, advindos do planalto das Guianas (Trombetas, Branco e Jari) com vazões específicas variando entre 15 e 40 1/s/km²; a zona $2 \mathrm{~S}$ (sul) dos afluentes da margem direita do Rio Solimões (Purus e Juruá), a porção da alta bacia do rio Madeira juntamente com seus tributários bolivianos, com os mesmos valores de vazão; a zona 3 correspondente aos cursos médios e inferior do rio Madeira e os demais afluentes da margem direita do rio Amazonas à jusante de Manaus e apresentam vazões específicas entre 5 e $25 \mathrm{l} / \mathrm{s} / \mathrm{km}^{2}$; e a zona 4, composta pelo rio Solimões-Amazonas, é resultante de todas as componentes regionais e as descargas específicas variam de 34 a 50 1/s/ $/ \mathrm{km}^{2}$ (FILIZOLA et al., 2002).

Quanto à variabilidade anual, a relação entre as vazões médias mensais extremas $(\mathrm{R}=$ QmmMax/QmmMin), os tributários meridionais do rio Amazonas apresentam valores relativamente elevados. Estes tributários meridionais se caracterizam por um máximo de cheia em março (Xingu, Tapajós, Madeira), abril (Juruá) ou maio (Purus). Este máximo hidrológico é observado em fevereiro nos formadores do rio Madeira, nos Andes bolivianos e peruanos. $\mathrm{Na}$ bacia do rio Madeira, $\mathrm{R}$ varia de 7,0 no piemonte andino (rio Beni) a 5,7 (rio Madeira em Manicoré). Os outros grandes tributários da margem direita têm valores de R comparáveis: rio Juruá: 7,6; rio Purus: 6,0; rio Tapajós: 4,7. A exceção é o rio Xingu que apresenta valor mais alto $(\mathrm{R}=15,7)$ devido à existência de um período seco bem marcado em sua bacia. $\mathrm{O}$ regime dos afluentes da margem esquerda é bem mais regular devido a uma distribuição pluviométrica mais regular, com valores de $\mathrm{R}$ geralmente inferiores a 3: rio Içá: 1,9; rio Japurá: 2,5; rio Negro: 2,5. Os cursos d'água provenientes do escudo guianense apresentam 
variabilidade comparável à dos rios andinos: rio Branco: 8,0; rio Jari: 8,1. Os máximos hidrológicos são observados em maio (rio Jari), junho (rio Içá) ou julho (rio Japurá, rio Negro, rio Branco). O rio Solimões-Amazonas é caracterizado por um regime bastante regular, com uma relação entre as descargas médias mensais extremas sempre próximas de 2: São Paulo de Olivença: 2,3; Manacapuru: 2,0; Óbidos: 2,0. As contribuições sucessivas dos rios da margem esquerda e da margem direita combinam-se para originar, mais a jusante, a grande enchente anual do rio Amazonas (MOLINIER et al., 1994).

Espinoza et al. (2009) investigaram a variabilidade espacial das descargas, no período de 1974-2004, na bacia hidrográfica do Amazonas. Foram analisados dados de 18 estações hidrométricas localizadas nas principais sub-bacias. Para cada sub-bacia, foram obtidos os coeficientes de variação sazonal (sVC), ou seja, a razão entre o desvio padrão dos valores médios mensais (1974-2004) e a média dos valores médios mensais. O coeficiente de variação sazonal (sVC) é elevado nas bacias do Sul: cerca de 0,60 na estação de Porto Velho (PVE) e 0,65 na estação residual Fazenda Vista Alegre (FVA) no rio Madeira, na estação virtual do Gavião-Lábrea (G-L) nos rios Juruá e Purus respectivamente e na estação de Itaituba (ITA) no rio Tapajós; e no extremo Norte e Sul: 0,74 na estação de Caracaraí (CAR) no rio Branco e 0,88 em Altamira (ALT) no rio Xingu, onde o clima é muito seco no inverno austral. Nas outras estações, Tamshiyacu (TAM) no rio Amazonas - Peru, Estação residual de Santo Antônio do Içá (SAI*) no rio Solimões, Acanauí (ACA) no rio Japurá, Serrinha (SER) no rio Negro e Óbidos (OBI) no rio Amazonas, o ciclo anual é mais fraco. Nessas bacias os valores de sVC são baixos, entre 0,26 e 0.35. Em OBI o valor de sVC é baixo, influenciado pelas estações noroeste que fornecem a maior quantidade de água para o curso médio, mas também pela combinação com o retardamento dos fluxos afluentes, criando uma hidrograma a jusante com uma única e grande inundação.

As bacias do sul (PVE, FVA, G-L, ALT e ITA) apresentam um máximo de cheia de março a maio e um mínimo de agosto a outubro, enquanto as do norte (CAR) apresentam um máximo de cheia de junho a agosto e um mínimo de dezembro a março. Nas estações de TAM, SAI*, ACA, SER e OBI, as descargas máximas geralmente ocorrem de maio a julho e um mês mais cedo na TAM, onde parte da bacia é tropical, e as descargas mínimas são observadas a partir de setembro e novembro e um mês mais cedo em TAM. Na bacia hidrográfica do Amazonas os diferentes regimes de descarga estão em conformidade com a 
sazonalidade da precipitação e com os regimes de descargas descritos por Molinier et al. (1996) (ESPINOZA et al., 2009)

De acordo com Filizola et al. (2009) a estação hidrométrica do Porto de Manaus não possui as condições ideais para realizar medições de descarga do rio Negro utilizando-se de métodos tradicionais. O regime local é controlado pelas águas do Rio Solimões cuja descarga é maior e causa um efeito de barramento das águas do Rio Negro. O nível das águas do rio Negro em Manaus não é somente controlado pela descarga, mas também pelo nível das águas do Solimões. Neste estudo realizado por Filizola e colaboradores, 4 locais próximos ao ponto de confluência entre as águas do rio Solimões e rio Negro foram estudados e comparados pela primeira vez, utilizando dados de descarga de dispositivo Doppler ao invés de dados de cotas. As relações entre descarga, cota e velocidade das águas foram estabelecidas e comparadas para cada período (cheia, vazante, subida e descida das águas) ao longo do ciclo hidrológico 2006-2007. Os dados obtidos mostram que as descargas e velocidades do rio Solimões são sempre maiores que o rio Negro, mesmo durante o período de águas baixas no Solimões. Isso significa que o sistema fluvial rio Negro/rio Solimões, perto de seu ponto de confluência, é controlado pelo rio Solimões. O rio Solimões possui, em média, descarga 2,5 vezes maior do que o rio Negro e velocidade das águas 3 vezes maior.

O resultado da análise de diferença de cota usando dados de estações virtuais indica que a declividade do Rio Solimões é maior do que o Rio Negro. Esta variação de declividade da água parece indicar condições de canal sob o domínio de diferentes sistemas geomorfológicos na área. Também foi identificada no rio Amazonas uma maior variação de declividade após o ponto de confluência. As diferenças encontradas entre o rio Solimões, rio Negro e rio Amazonas, observando-se os parâmetros hidrométricos ( $Q$, V e $H)$, provavelmente estão relacionados a essa maior variação da declividade (FILIZOLA et al., 2009).

A amplitude das variações de cotas (diferença entre as cotas máximas e mínimas) foi estudada por Filizola et al. (2002) para o conjunto da bacia do Amazonas, considerando o período 1970-1996. Os resultados obtidos mostram que essa amplitude varia de 2 a $18 \mathrm{~m}$ no decorrer do ano hidrológico (Figura 24). Os valores mínimos (de 2 a 4 m) são observados nas cabeceiras, nos rios que drenam os escudos (rios Branco, Jari, Xingu, Tapajós e Guaporé) e os valores máximos de amplitude anual das cotas (de 15 a $18 \mathrm{~m}$ ) foram registrados nos trechos 
inferiores dos rios Juruá, Purus e Madeira. Sobre o rio Solimões-Amazonas, essas amplitudes variam de $12 \mathrm{~m}$ (Teresina, próximo à fronteira Peru - Brasil) até $15 \mathrm{~m}$ (Manacapuru), para depois ir baixando regularmente para $8 \mathrm{~m}$ em Óbidos e finalmente $3 \mathrm{~m}$ em Macapá.

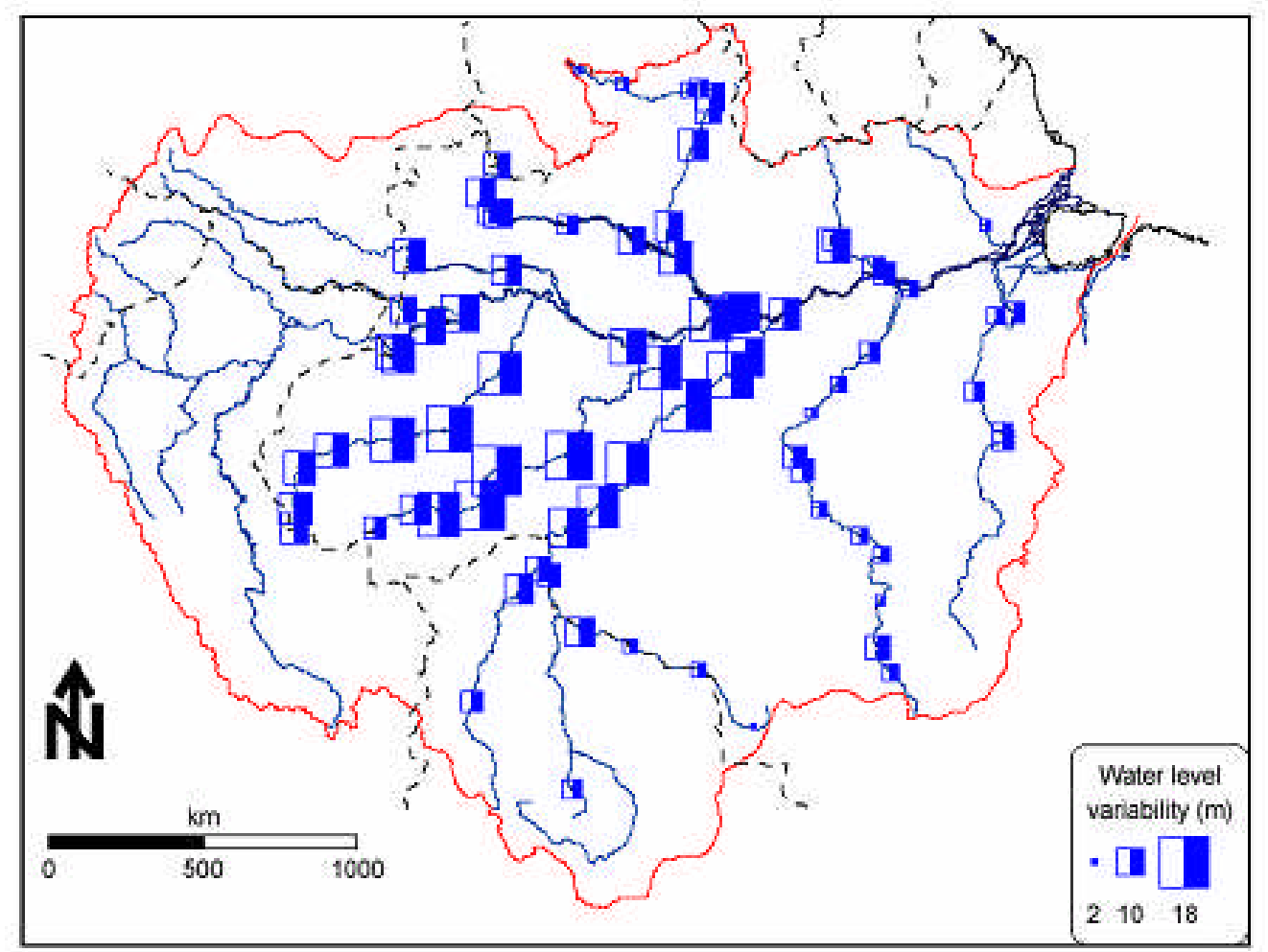

Figura 24: Variabilidade sazonal dos níveis dos rios na Bacia Amazônica Fonte: FILIZOLA et al. (2002)

No sistema rio Solimões-Amazonas, a variabilidade sazonal das cotas na estação de Teresina $\left(983.160 \mathrm{~km}^{2}\right)$ apresentou um hidrograma plurianual com um primeiro pico em dezembro-janeiro, e um segundo mais importante em abril-junho. A jusante, na estação de Manacapuru (2.147.740 $\mathrm{km}^{2}$ ), o hidrograma é um pouco mais regular, com um pico de cheia, máximo de maio a agosto, com um pequeno pico de cheia precoce observado em janeirofevereiro. A jusante de Manaus, na estação hidrométrica de Óbidos $\left(4.618 .810 \mathrm{~km}^{2}\right)$, apresenta um máximo de cheia único e suave de abril a julho, que representa a composição dos aportes dos rios Solimões, Negro e Madeira (FILIZOLA et al., 2002).

Sobre o rio Negro, as estações de Curicuriari, próxima a São Gabriel da Cachoeira $\left(194.460 \mathrm{~km}^{2}\right)$ e de Barcelos $\left(367.250 \mathrm{~km}^{2}\right)$ apresentam hidrogramas bi-modais, com um primeiro pico de cheia em janeiro e um segundo, mais importante, no período junho - 
setembro. Mais para jusante, em Manaus $\left(696.810 \mathrm{~km}^{2}\right.$ ), o rio Negro apresenta um hidrograma sem relação direta com os de Curicuriari ou de Barcelos, que, no entanto é bastante similar ao de Manacapuru, no rio Solimões que apresenta um hidrograma mais regular, com um pico de cheia, máximo de maio a agosto, e um pequeno pico de cheia precoce, observado em janeiro-fevereiro (FILIZOLA et al., 2002).

Os registros das cotas do rio Negro, obtidos ao longo de 300-400 km do rio, evidenciam os efeitos de barramento hidráulico do sistema Solimões-Amazonas. Em Moura, localizada a $300 \mathrm{~km}$ da foz, o padrão de variação anual da cota do rio é mais semelhante à foz do que às estações mais à montante. Nesta estação, o rio Negro apresenta as cotas mais baixas do ano em outubro e novembro, enquanto nas estações mais distantes à montante (Barcelos) as cotas mais baixas ocorrem em fevereiro ou março. As cotas medidas no curso superior e médio do rio Negro em Barcelos continuam a cair em dezembro e janeiro, enquanto no curso inferior, a jusante de Moura, já começou a subir. Na verdade, as cotas registradas no rio Negro pela estação de Manaus são fortemente influenciadas pelos níveis do rio Solimões, não correspondendo à vazão do rio Negro. Este efeito de barramento hidráulico é largamente observado em todos os afluentes do rio Solimões-Amazonas (MEADE et al.,1991). 


\section{ANÁLISES E CORRELAÇÕES}

\subsection{ANÁLISE HIDROMETEOROLÓGICA DA BACIA DO RIO NEGRO}

A análise hidrometeorológica da área de estudo foi realizada a partir do tratamento e análise dos dados disponibilizados pela Agência Nacional de Águas - ANA que realiza o monitoramento hidrometeorológico da Amazônia. As estações fornecem dados de chuva, nível de água (cotas fluviais), vazão e carga de sedimentos. Os dados de chuva disponibilizados pelo Instituto Nacional de Meteorologia - INMET, também foram utilizados.

Para a Bacia Amazônica (Código 1) as estações fluviométricas e pluviométricas estão divididas e dispostas em 10 sub-bacias codificadas, a Bacia do Rio Negro é codificada como de número 14 (Rio Solimões, Negro, Branco). Na área de estudo, abrangendo toda a bacia do rio Negro, a base da ANA apresenta o seguinte quantitativo em termos de estações: 87 estações com dados de chuvas, 60 estações com dados de cotas e 34 estações com dados de vazão. Parte da dificuldade de se trabalhar com essa base de dados é o fato de que algumas estações apresentam dados inconsistentes, lacunas nos dados, ou não possuem séries históricas de longo período, aqui não foi adotado o método de preenchimento de lacunas, pois estas são de meses consecutivos e até mesmo anos.

\subsubsection{Caracterização Pluviométrica}

Guyot et al. (1993) buscando analisar os principais componentes do balanço hídrico da Bacia do Rio Negro, utilizaram dados de 120 postos pluviométricos e 52 estações fluviométricas, para o período de 20 anos. A partir deste estudo os autores subdividiram a área da bacia do rio Negro em três vetores regionais com base nas tendências pluviométricas para o período de 1973-1992, denominados de vetor 1: bacia do rio Negro até Serrinha; vetor 2: bacia do rio Branco até Caracaraí e vetor 3: jusantes das bacias dos rios Negro e Branco, até Manaus (Figura 25). A pluviometria média para a totalidade da bacia hidrográfica é de $2.566 \mathrm{~mm} / \mathrm{ano}$, com uma tendência ao aumento de leste para oeste. Na sub-bacia do Rio Negro a montante de Serrinha, a pluviometria média é de $2.980 \mathrm{~mm} / \mathrm{ano}$ e varia de 2.000 a 3.600 mm/ano. Os três meses mais úmidos (de maio a julho) representam $30 \%$ das precipitações anuais, e não existe estação seca bem definida. Na sub-bacia do Rio Branco, as precipitações 
variam de 1.400 a $2.300 \mathrm{~mm} / \mathrm{ano}$, para um valor médio de $1.830 \mathrm{~mm} / \mathrm{ano}$. Nesta, o regime sazonal é mais marcado e os três meses úmidos totalizam $57 \%$ da pluviometria anual. $\mathrm{Na}$ região à jusante da bacia, a estação das chuvas aparece mais cedo e a máxima pluviométrica ocorre em maio na região de Santa Maria do Boiacu e, em março-abril, na região de Manaus. Os três meses mais chuvosos totalizam de 35 a $40 \%$ da pluviometria anual.

Estudo semelhante foi realizado por Carvalho, B. S. e Alves (2013, no prelo) objetivando a análise do regime pluviométrico na Bacia hidrográfica do Rio Negro nos últimos 20 anos no período de 1992 - 2011. Neste estudo a mesma divisão da bacia em vetores foi adotada (Figura 25). O Vetor 1 apresentou uma média de 3.078,1 mm/ano sendo abril, maio e junho os meses mais úmidos, e setembro, outubro e novembro os meses mais secos; o Vetor 2 apresentou média de 1.874,6 mm/ano, sendo os meses mais úmidos maio, junho e julho, e os mais secos janeiro, fevereiro e março; e o Vetor 3 apresentou a média de 2.316,1 mm/ano com os meses mais úmidos abril, maio e junho, e os mais secos agosto, setembro e outubro.

Para a caracterização pluviométrica da bacia do rio Negro necessária a esta pesquisa, foram analisados os dados para série histórica de 30 anos, de 1982 a 2011 das estações, de montante para jusante, ao longo do rio Negro: São Felipe - 8067001, Tapuruquara - 65001, Moura - 161002 e Manaus - 82331, esta com dados disponibilizados pelo INMET (Quadro 7).

Quadro 7: Estações com dados de chuva no Rio Negro selecionadas

\begin{tabular}{|c|c|c|c|c|}
\hline Estação & Código & Localização & Município & Histórico \\
\hline São Felipe & 8067001 & $\begin{array}{l}\text { Lat. } 0^{\circ} 22^{\prime} 15.96 " \mathrm{~N} \\
\text { Long. 67¹8'48.96" W }\end{array}$ & 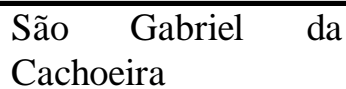 & 1977 a 2011 \\
\hline Tapuruquara & 65001 & $\begin{array}{l}\text { Lat. } 0^{\circ} 25^{\prime} 13.08^{\prime \prime} \mathrm{S} \\
\text { Long. } 65^{\circ} 00^{\prime} 55.08^{\prime \prime} \mathrm{W}\end{array}$ & $\begin{array}{l}\text { Santa Isabel do Rio } \\
\text { Negro }\end{array}$ & 1982 a 2012 \\
\hline Moura & 161002 & $\begin{array}{l}\text { Lat. } 1^{\circ} 27^{\prime} 32.04^{\prime \prime} \mathrm{S} \\
\text { Long. } 61^{\circ} 37^{\prime} 59.16^{\prime \prime} \mathrm{W}\end{array}$ & Barcelos & 1979 a 2011 \\
\hline Manaus & 82331 & $\begin{array}{l}\text { Lat. } 3.11^{\circ} \mathrm{S} \\
\text { Long. } 59.95^{\circ} \mathrm{W}\end{array}$ & Manaus & 1910 a 2012 \\
\hline
\end{tabular}

Fonte: ANA e INMET (2012) 


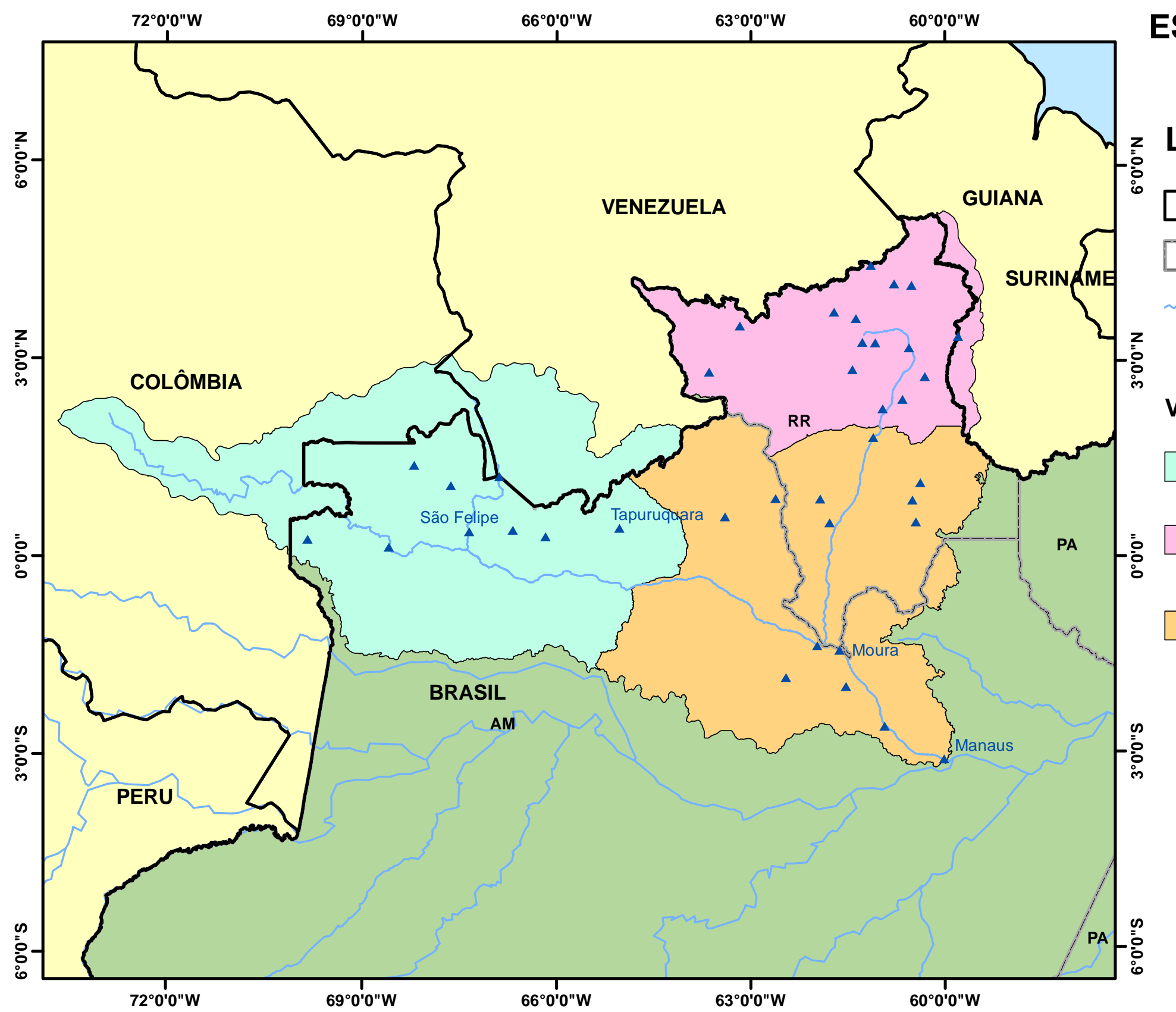

ESTAÇÕES PLUVIOMÉTRICAS E VETORES REGIONAIS

LEGENDA

$\square$ Limite Internacional

L_ Limite Interestadual

$\sim$ Hidrografia

- Estações Pluviométricas

\section{VETORES REGIONAIS}

Vetor 1: Bacia do Rio Negro até Serrinha

Vetor 2: Bacia do Rio Branco até Caracaraí

Vetor 3: Jusante das Bacias do Rio Negro e Rio Branco até Manaus

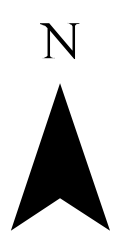

1:10.000.000
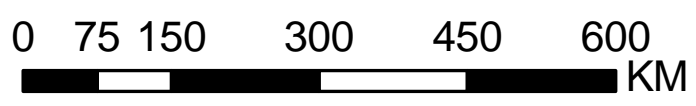

Datum SAD 69 Coordenadas LAT/LONG CPRM (2008)

Figura 25: Vetrores regionais e tendências pluviométricas

Fonte: Adaptado de CARVALHO, B.S. e Alves, 2013 (no prelo) 
A estação de São Felipe, localizada no Alto Rio Negro no município de São Gabriel da Cachoeira, apresenta uma pluviosidade média mensal histórica para a série de 30 anos de $2.867 \mathrm{~mm}$, com máxima pluviosidade anual de $4.135 \mathrm{~mm}$ e mínima de $1.739 \mathrm{~mm}$ (Figura 26). Os meses de abril, maio e junho são os mais úmidos e não existe estação seca bem definida, padrão observado também para a Estação de Tapuruquara localizada no município de Santa Isabel do Rio Negro, a jusante. A Estação de Tapuruquara apresenta uma pluviosidade média mensal histórica para a série histórica considerada (1982-2011) de 2.427 mm, com máxima e mínima pluviosidade anual de $2.957 \mathrm{~mm}$ e $1.844 \mathrm{~mm}$, respectivamente (Figura 27). Estas estações apresentam valores coincidentes com os estudos de Guyot et al. (1993) e Carvalho, B. S. e Alves (2013, no prelo) obtidos para o Vetor 1.

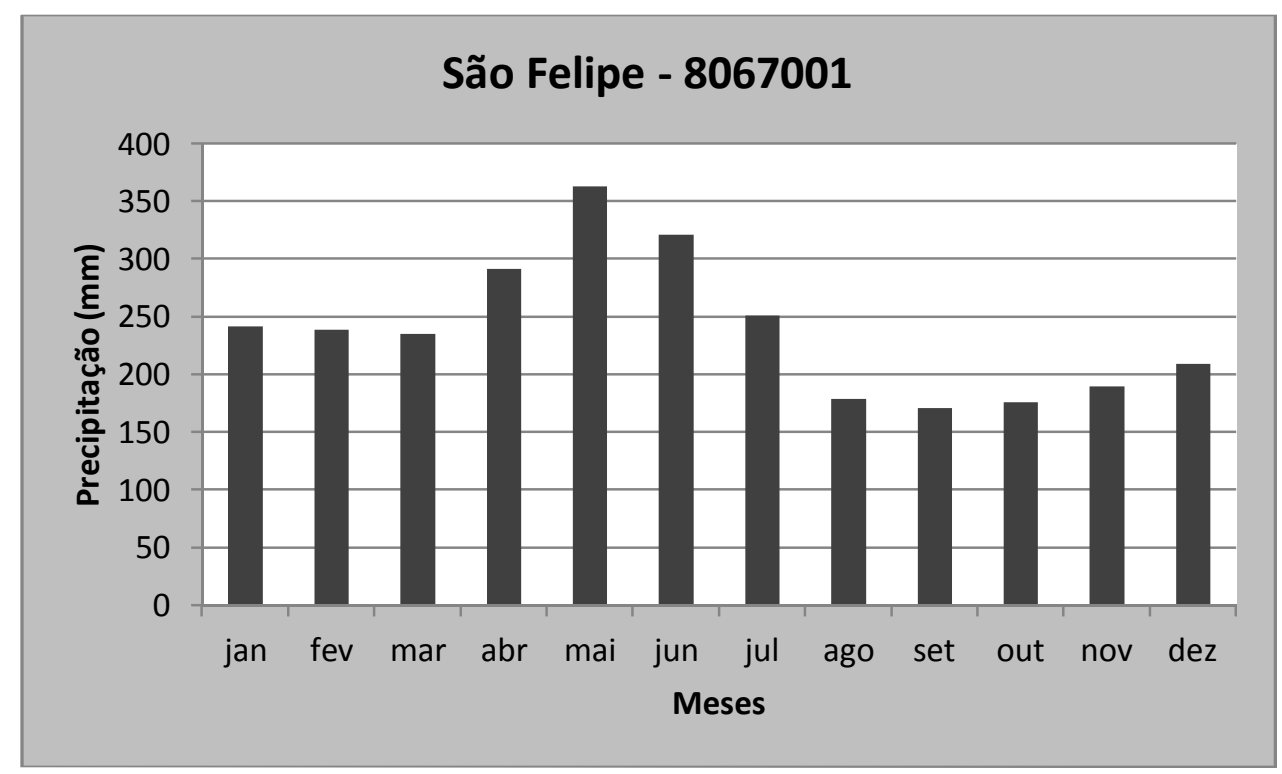

Figura 26: Precipitação Média Mensal Histórica (1982-2011) para Estação São Felipe - 8067001 Fonte: Dados das Estações da ANA

Elaboração: ALVES (2012) 


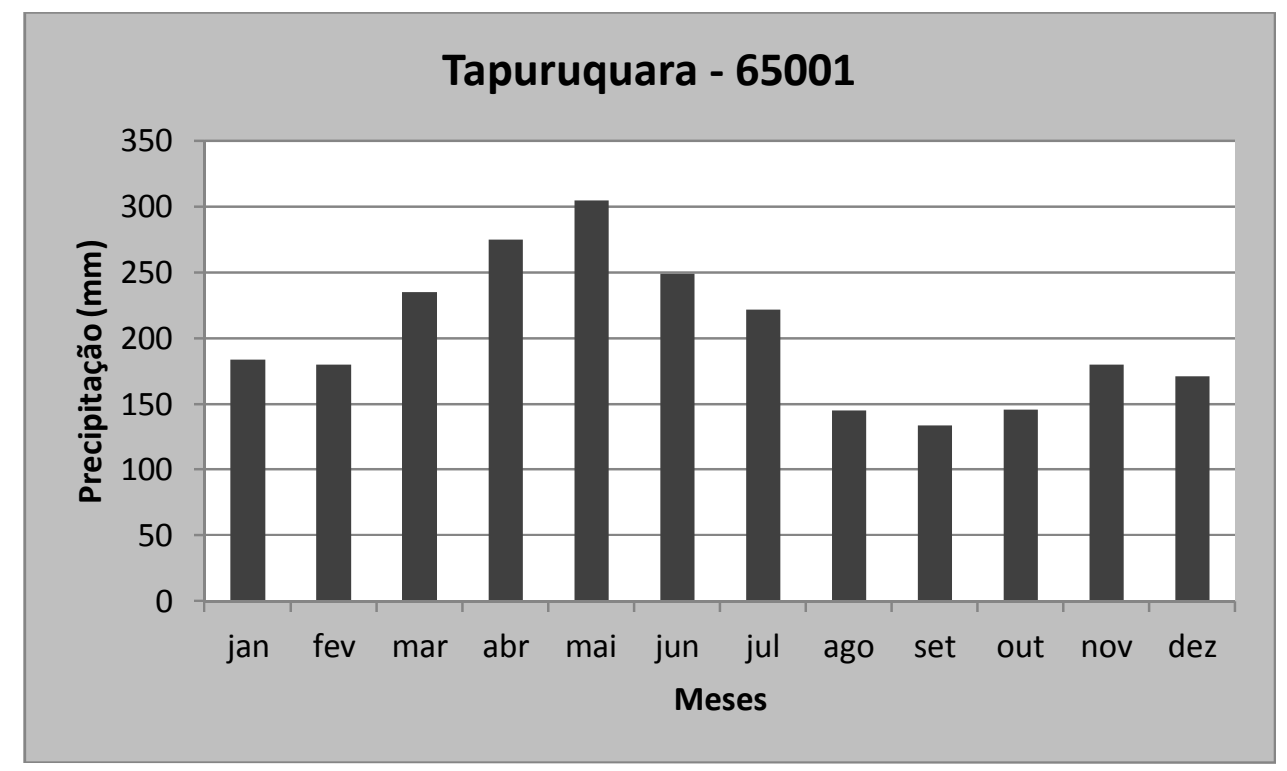

Figura 27: Precipitação Média Mensal Histórica (1982-2011) para Estação Tapuruquara - 65001 Fonte: Dados das Estações da ANA Elaboração: ALVES (2012)

A Estação de Moura, localizada no Médio Rio Negro no município de Barcelos, apresenta uma pluviosidade média mensal histórica de $2.266 \mathrm{~mm}$ para a série considerada, com máxima pluviosidade anual de $3.286 \mathrm{~mm}$ e mínima de $1.474 \mathrm{~mm}$. Os meses mais úmidos são março e abril e uma estação seca em agosto e setembro (Figura 28).

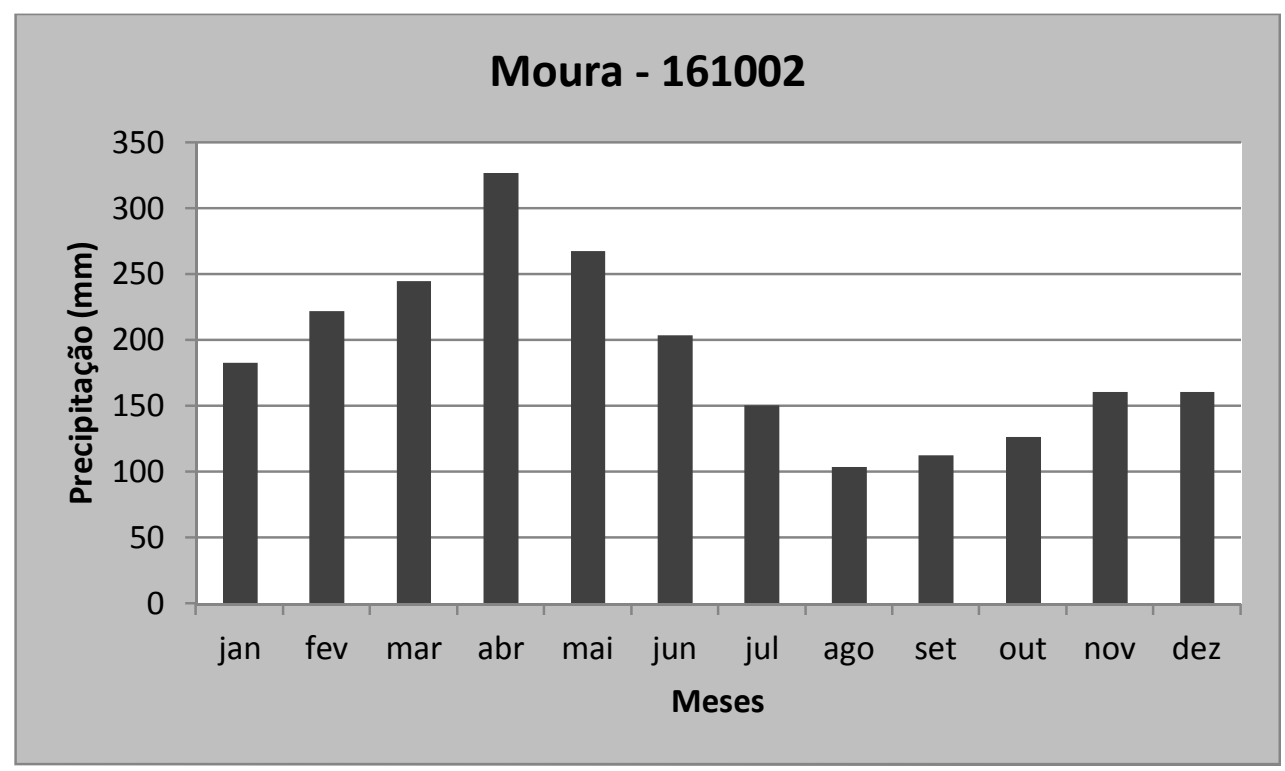

Figura 28: Precipitação Média Mensal Histórica (1982-2011) para Estação Moura - 161002 Fonte: Dados das Estações da ANA

Elaboração: ALVES (2012) 
A Estação de Manaus, localizada no Baixo Rio Negro próximo a sua foz, no município de Manaus apresenta uma pluviosidade média mensal histórica de $2.291 \mathrm{~mm}$, com máxima pluviosidade média anual de $3.160 \mathrm{~mm}$ e mínima de $1.260 \mathrm{~mm}$. Apresenta regime sazonal bem marcado, com máxima pluviosidade em fevereiro-abril e uma estação seca bem definida de julho-setembro (Figura 29).

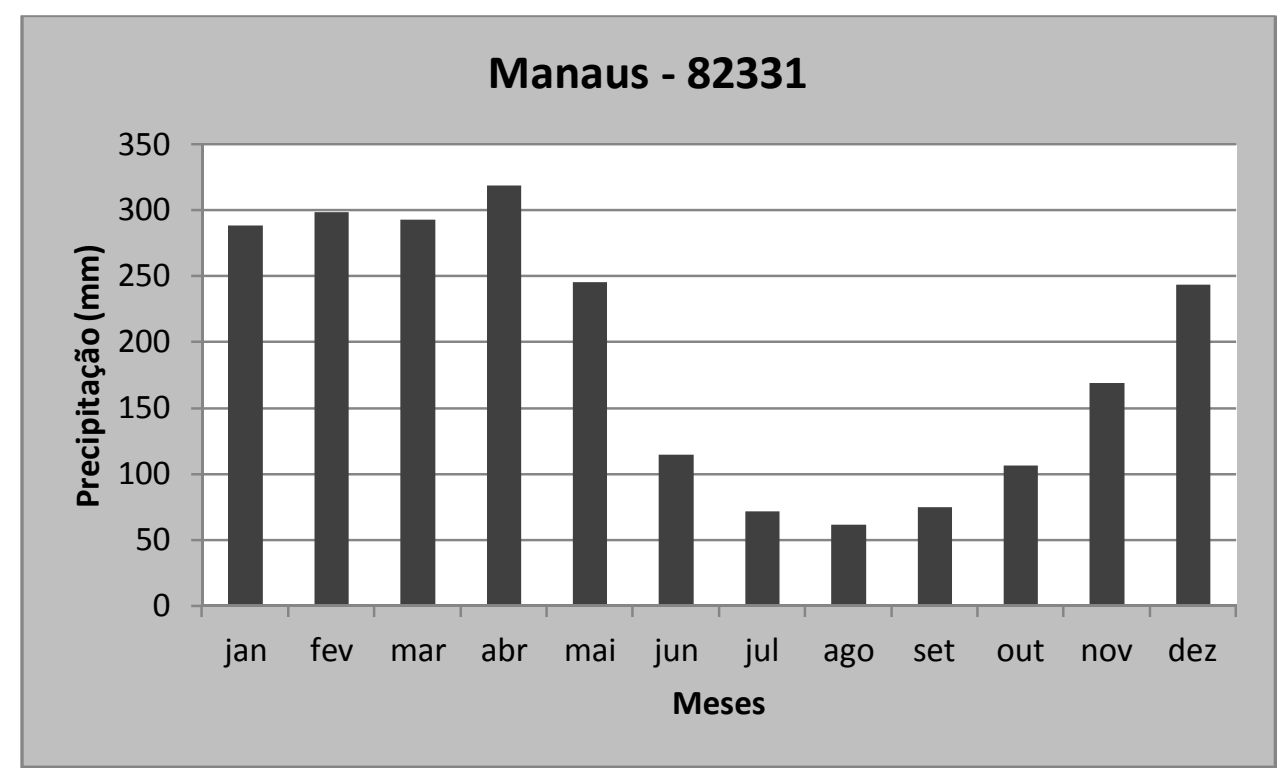

Figura 29: Precipitação Média Mensal Histórica (1982-2011) para Estação Manaus - 82331 Fonte: Dados da Rede do INMET Elaboração: ALVES (2012)

Os valores de pluviosidade média mensal histórica das estações de São Felipe, Tapuruquara, Moura e Manaus, localizadas de montante a jusante do rio Negro respectivamente, são análogos aos valores obtidos nos estudos de Guyot et al. (1993) e Carvalho e Alves (2013, no prelo), que definiram uma subdivisão da bacia do rio Negro em três vetores regionais baseado em tendências pluviométricas paras as séries históricas estudadas. Um aumento na pluviosidade média é observado de jusante a montante do rio Negro, com máximas no município de São Gabriel da Cachoeira. As estações mais a montante (São Felipe e Tapuruquara) apresentam máximas pluviométricas nos meses de maio-junho, enquanto as estações a jusante (Moura e Manaus) em março-abril.

A área do Arquipélago de Anavilhanas localiza-se entre as estações de Moura e Manaus e possui uma estação pluviométrica localizada no município de Novo Airão (Novo Airão - 260006) cuja pluviosidade média mensal histórica é de $2.100 \mathrm{~mm} / \mathrm{ano}$ e possui comportamento anual semelhante às estações de Moura e Manaus, localizadas a montante e 
jusante, respectivamente, compatível com os valores obtidos por Guyot et al. (1993) e Carvalho, B. S. e Alves (2013, no prelo) para o Vetor 3.

\subsubsection{Caracterização Hidrológica do Rio Negro}

Para a análise do regime hidrológico do rio Negro foi realizado o levantamento das estações fluviométricas localizadas no rio Negro que apresentasse dados de vazão. O número de estações com esse tipo de dado é bastante restrito, incluindo apenas as estações de Cucuí (14110000), São Felipe (14250000), Curicuriari (14330000), Serrinha (14420000) e Paricatuba (14990000) em Manaus. Todas as estações possuem dados com série histórica com mais de 30 anos, a exceção da estação de Paricatuba que possui apenas uma única medição de vazão mensal para os anos de 2006 a 2011. As medições de Paricatuba foram efetuadas pela CPRM para monitoramento das cheias e vazante do sistema Solimões-Negro-Amazonas, e os dados de vazão foram obtidos nos relatórios de monitoramento disponibilizados pelo órgão em seu site. Para os anos de 2006, 2007, 2008 e 2011 os dados estão incompletos, ou seja, sem medição referente a cada mês do ano.

Foram considerados os dados para uma série histórica de 30 anos (1982 a 2011) das estações fluviométricas, de montante à jusante do rio Negro, Cucuí, São Felipe, Curicuriari e Serrinha (Figura 38), e os dados disponíveis para a estação de Paricatuba, para análise do regime hidrológico do rio Negro próximo a sua foz e comparação com os dados disponíveis para as demais estações (Quadro 8).

A análise da série histórica (1982 a 2011) dos dados de vazão, disponibilizados para as estações de Cucuí, São Felipe, Curicuriari e Serrinha, todas localizadas à montante de Anavilhanas, caracteriza o regime hidrológico do rio Negro, ou seja, dois picos máximos anuais, um no primeiro trimestre do ano (jan-mar) de menor intensidade, e o segundo no meio do ano e de maior intensidade correspondente à máxima anual (jun-jul), e período de águas altas de maio a agosto (Figuras 30, 31, 32 e 33) com um máximo observado em todas as estações em junho-julho, regime este definindo como do tipo Equatorial por Rodier (1964) apud Molinier et al. (1996). 
Quadro 8: Estações fluviométricas selecionadas

\begin{tabular}{|c|c|c|c|c|}
\hline Estação & Código & Localização & Município & $\begin{array}{c}\text { Série } \\
\text { Histórica }\end{array}$ \\
\hline Cucuí & 14110000 & $\begin{array}{l}\text { Lat. } 1^{\circ} 12^{\prime} 55.08^{\prime \prime} \mathrm{N} \\
\text { Long. } 66^{\circ} 51^{\prime} 09.00^{\prime \prime} \mathrm{W}\end{array}$ & $\begin{array}{ll}\text { São } & \text { Gabriel } \\
\text { Cachoeira }\end{array}$ & 1982 a 2011 \\
\hline São Felipe & 14250000 & $\begin{array}{l}\text { Lat. } 0^{\circ} 22^{\prime} 18.12^{\prime \prime} \mathrm{N} \\
\text { Long. } 67^{\circ} 51^{\prime} 46.08^{\prime \prime} \mathrm{W}\end{array}$ & $\begin{array}{ll}\text { São Gabriel } & \text { da } \\
\text { Cachoeira } & \end{array}$ & 1982 a 2011 \\
\hline Curicuriari & 14330000 & $\begin{array}{l}\text { Lat. } 0^{\circ} 12^{\prime} 02.16^{\prime \prime} \mathrm{S} \\
\text { Long. } 66^{\circ} 48^{\prime} 07.92^{\prime \prime} \mathrm{W}\end{array}$ & 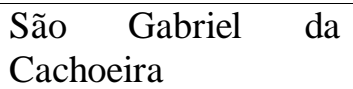 & 1982 a 2012 \\
\hline Serrinha & 14420000 & $\begin{array}{l}\text { Lat. } 0^{\circ} 28^{\prime} 54.84^{\prime \prime} \mathrm{S} \\
\text { Long. } 64^{\circ} 49^{\prime} 44.04^{\prime \prime} \mathrm{W}\end{array}$ & $\begin{array}{l}\text { Santa Isabel do Rio } \\
\text { Negro }\end{array}$ & 1982 a 2012 \\
\hline Paricatuba & 14990000 & $\begin{array}{l}\text { Lat. } 3^{\circ} 03^{\prime} 29.00^{\prime \prime} \mathrm{S} \\
\text { Long. } 60^{\circ} 15^{\prime} 52.00^{\prime \prime} \mathrm{W}\end{array}$ & Manaus & $\begin{array}{l}\text { Dados } \\
\text { mensais } 2006 \\
\text { a } 2011\end{array}$ \\
\hline
\end{tabular}

Fonte: Dados da ANA e CPRM

A vazão média histórica é de $4.952 \mathrm{~m}^{3} / \mathrm{s}$ para a estação de Cucuí; $8.134 \mathrm{~m}^{3} / \mathrm{s}$ para a estação de São Felipe; $12.663 \mathrm{~m}^{3} / \mathrm{s}$ para a estação de Curicuriari e $18.235 \mathrm{~m}^{3} / \mathrm{s}$ para a estação de Serrinha, observando assim um aumento nos débitos em direção de jusante no canal fluvial. As máximas médias da série histórica ocorreram nos meses de junho e julho durante a fase de cheia do rio Negro e corresponde ao período de máxima pluviosidade medidas nestas estações, localizadas na região definida por Guyot et al. (1993) como Vetor 1.

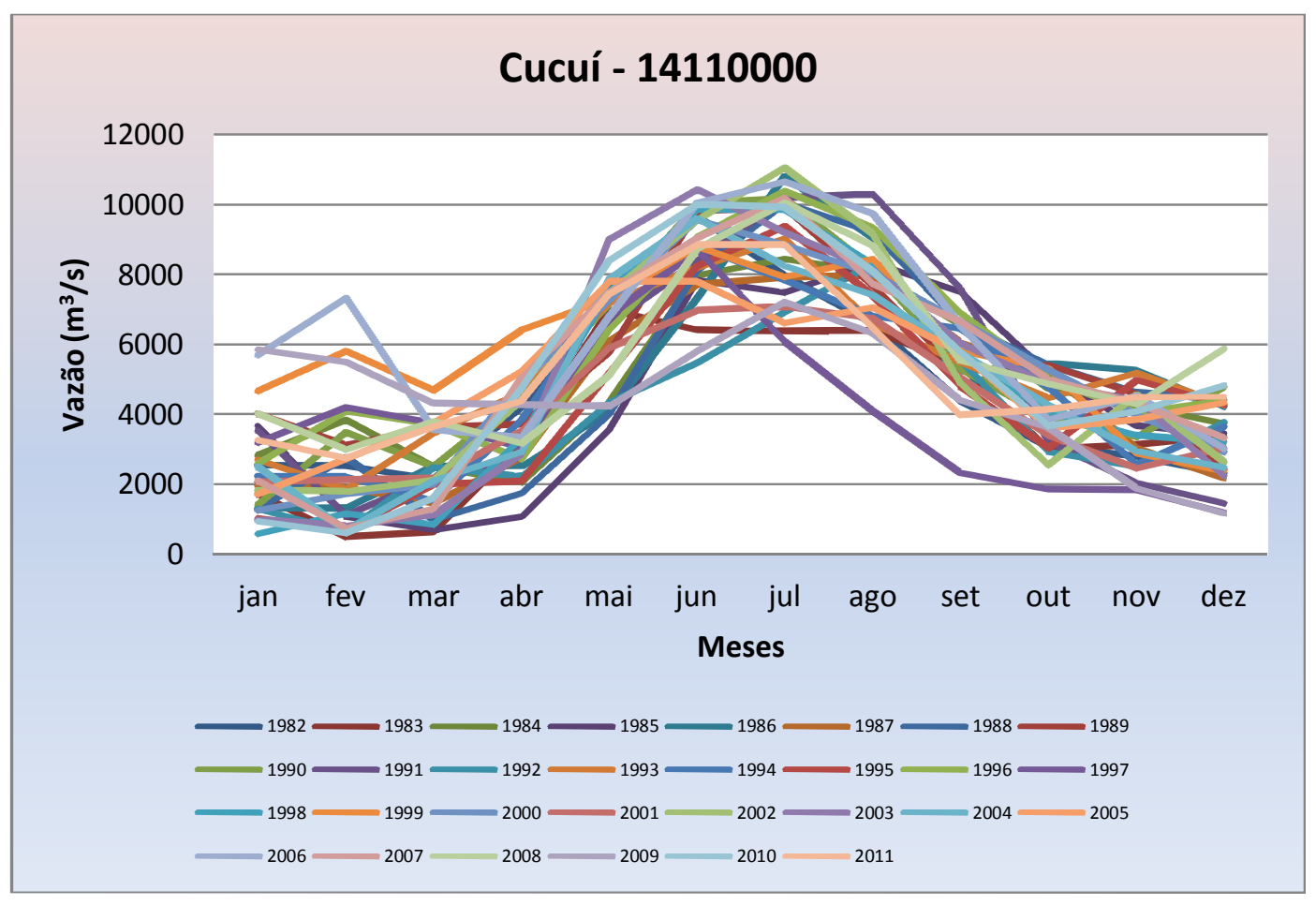

Figura 30: Estação de Cucuí - Vazão Média Mensal (1982-2011)

Fonte: ANA

Elaboração: ALVES (2012) 


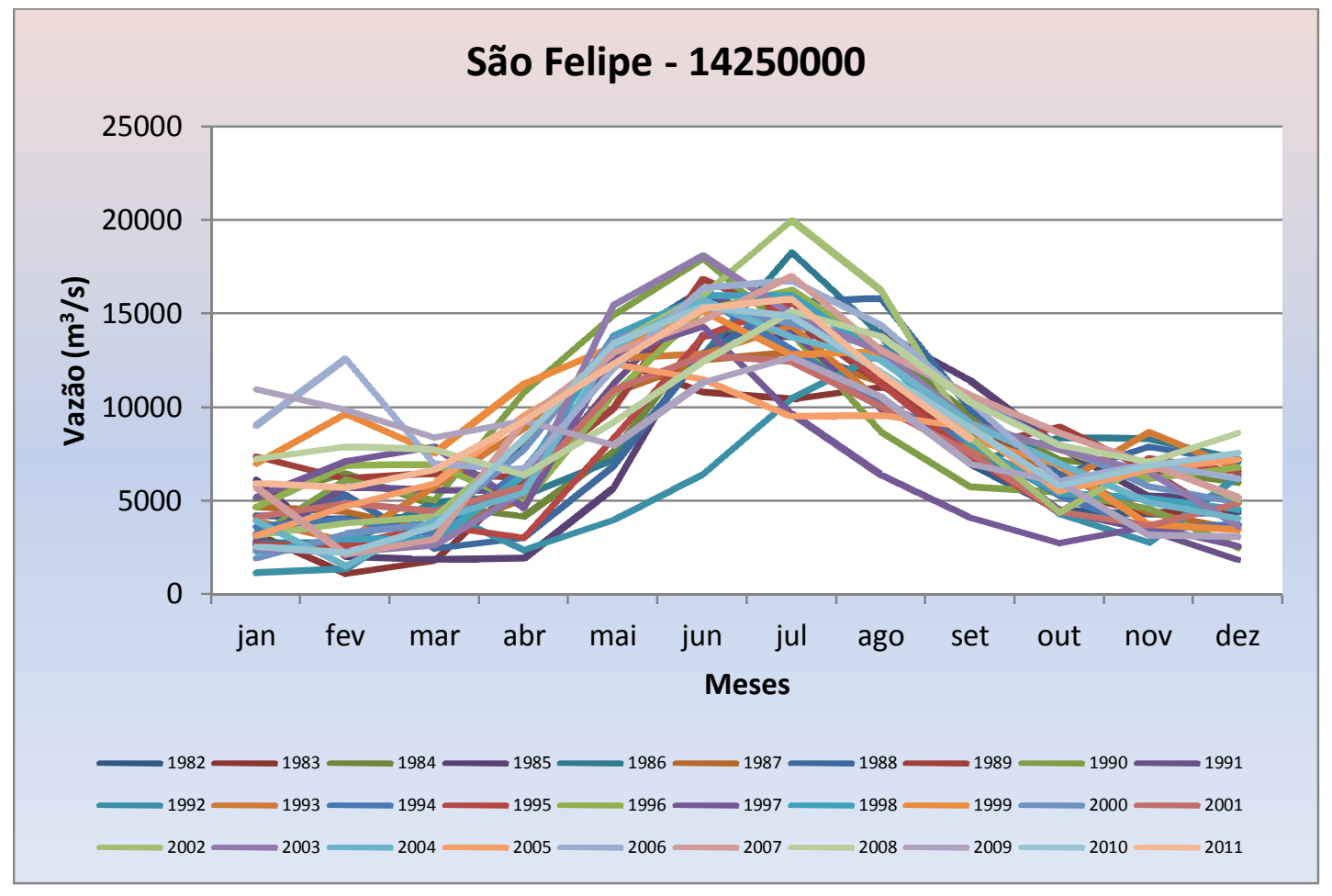

Figura 31: Estação de São Felipe - Vazão Média Mensal (1982-2011)

Fonte: ANA

Elaboração: ALVES (2012)

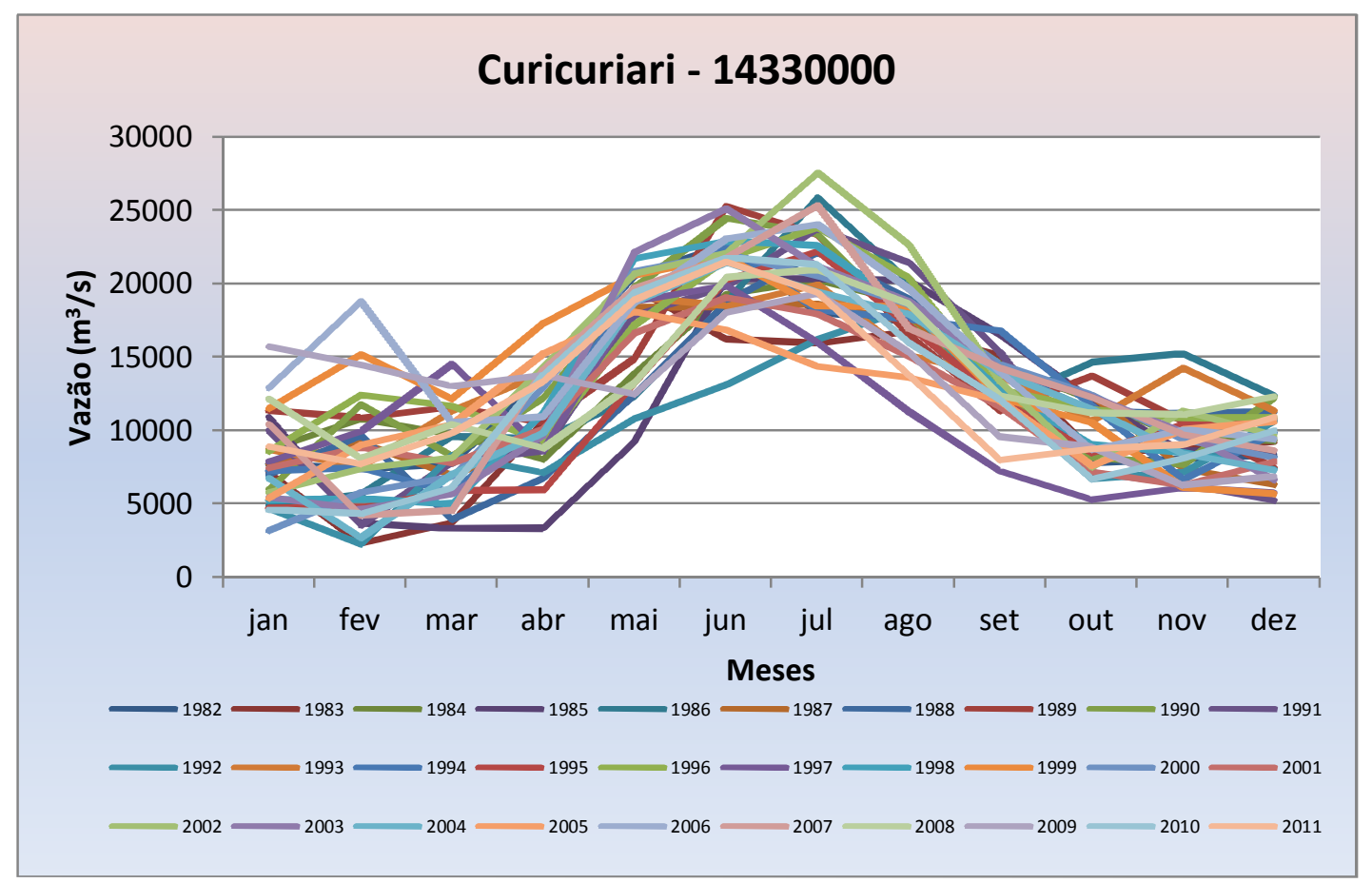

Figura 32: Estação de Curicuriari - Vazão Média Mensal (1982-2011)

Fonte: ANA

Elaboração: ALVES (2012) 


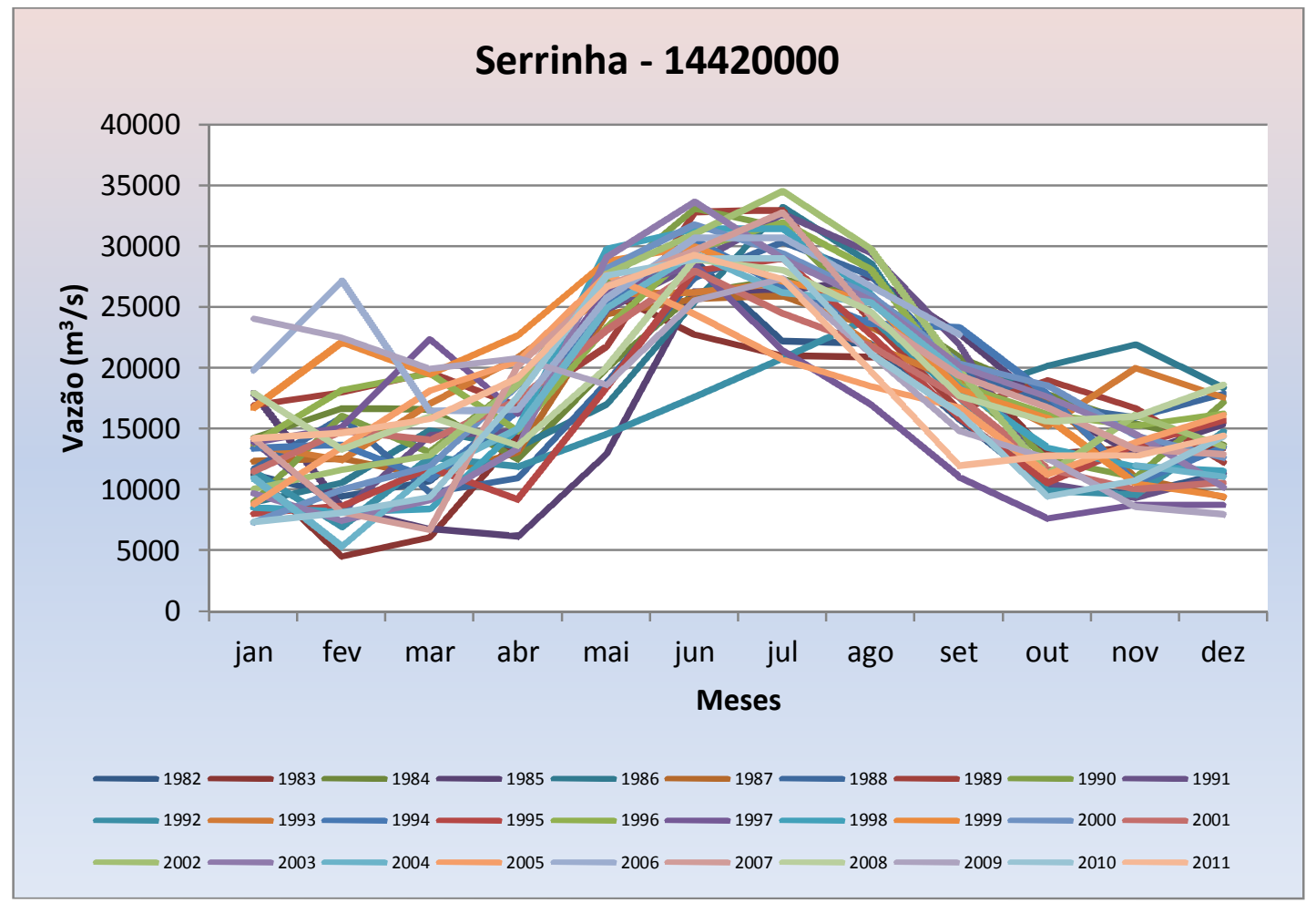

Figura 33: Estação de Serrinha - Vazão Média Mensal (1982-2011)

Fonte: ANA

Elaboração: ALVES (2012)

A ausência de medidas de descarga em Manaus deve-se à influência do rio Solimões na parte inferior do rio Negro. O regime local é controlado pelas águas do rio Solimões cuja descarga é maior e causa um efeito de barramento das águas do rio Negro. A estação de Paricatuba localiza-se na margem direita do rio Negro à montante de Manaus e a CPRM vêm, mensalmente, efetuado medidas de cargas para o monitoramento das cheias e vazantes do sistema Solimões-Negro-Amazonas, cujos anos de coleta de dados incluem 2006, 2007, 2008, 2009, 2010 e 2011. Para esta estação a vazão média medida para os anos considerados é de $33.356 \mathrm{~m}^{3} / \mathrm{s}$, com máxima de $59.603 \mathrm{~m}^{3} / \mathrm{s}$ para o mês de julho e mínima de $15.174 \mathrm{~m}^{3} / \mathrm{s}$ para o mês de dezembro (Figura 34). As vazões medidas nesta estação mostram valores máximos nos meses de junho e julho, coincidentes com a cheia anual do rio Negro. Os dados pluviométricos disponíveis para a estação de Manaus, no mesmo período, apresentam valores que não corresponde às máximas pluviométricas anuais, observação que permite considerar duas situações quanto ao comportamento hidrológico regional: o máximo pluviométrico na bacia do rio Negro, nas estações localizadas a montante de Manaus, ocorre no período de maio a julho e contribui, de maneira efetiva, para o aumento do volume de água na região do 
baixo rio Negro bacia, e o efeito de barramento hidráulico do rio Solimões sobre o rio Negro nas proximidades de Manaus.

A CPRM também disponibiliza dados de velocidade de fluxo medidas na estação de Paricatuba. A velocidade média de fluxo medida na estação é de 0,40 m/s, com máximas de $0,63 \mathrm{~m} / \mathrm{s}$ observadas durante o período de cheia do rio, e mínima de $0,23 \mathrm{~m} / \mathrm{s}$ observada durante o período de subida das águas. Observa-se um aumento proporcional da velocidade do fluxo à medida que a vazão se eleva (Figura 35).

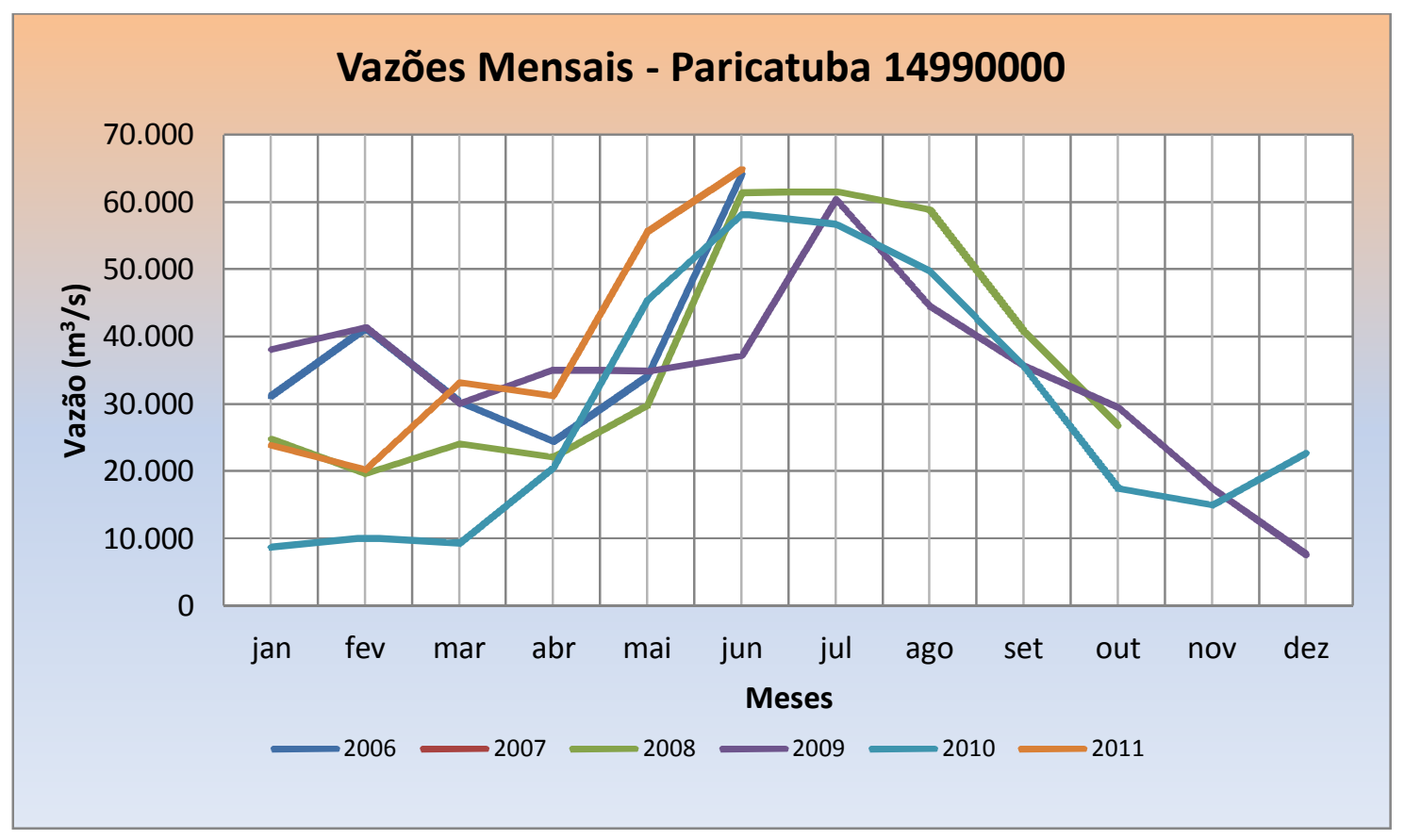

Figura 34: Estação de Paricatuba - Medidas de Vazão Mensal Fonte: CPRM

Elaboração: ALVES (2012) 


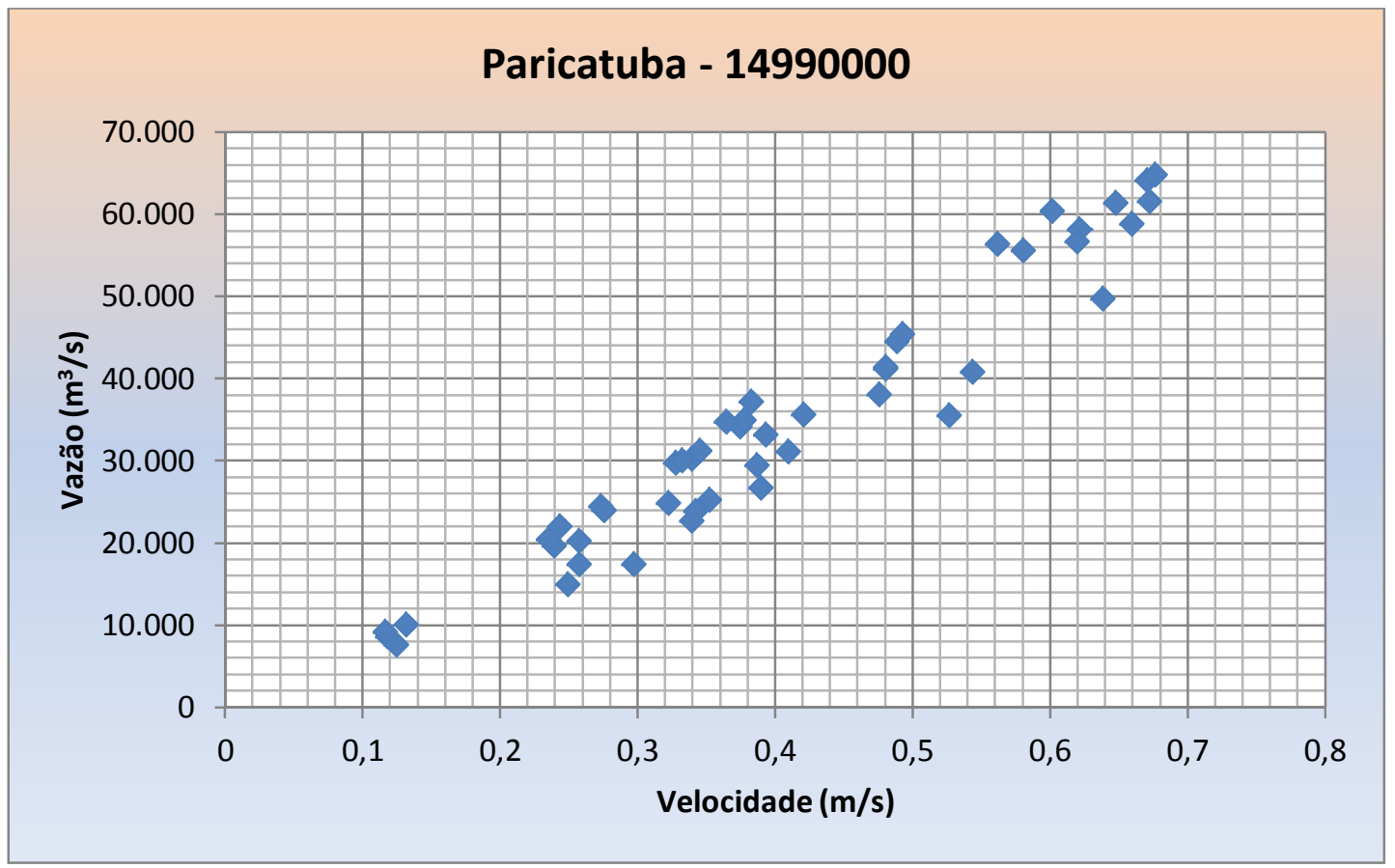

Figura 35: Relação Vazão x Velocidade para a estação de Paricatuba Fonte: CPRM

Elaboração: ALVES (2012)

A Agência Nacional de Águas - ANA disponibilizada dados de velocidades do rio Negro medidas nas estações de Cucuí e Serrinha, localizadas no alto e médio rio Negro, respectivamente. A velocidade média observada é de $0,87 \mathrm{~m} / \mathrm{s}$ para a estação de Cucuí; e de $0,91 \mathrm{~m} / \mathrm{s}$ para a estação de Serrinha. A velocidade máxima medida em Cucuí é de 1,20 m/s valor referente ao período de cheia do rio Negro, e a mínima medida é de 0,55 m/s. Em Serrinha a velocidade média máxima é de $1,16 \mathrm{~m} / \mathrm{s}$ e apresenta mínima de $0,67 \mathrm{~m} / \mathrm{s}$. Apesar de não existirem muitos dados para o rio Negro, observa-se que as velocidades de fluxo do rio são maiores nas regiões do alto e médio rio Negro do que na sua baixa região, favorecendo processos deposicionais nessa região (Figura 36). Essa redução da velocidade é atribuída ao efeito de barramento hidráulico causado pelo rio Solimões no local, devido a grande diferença de declividade existente entre os dois rios (FILIZOLA et al., 2009). 


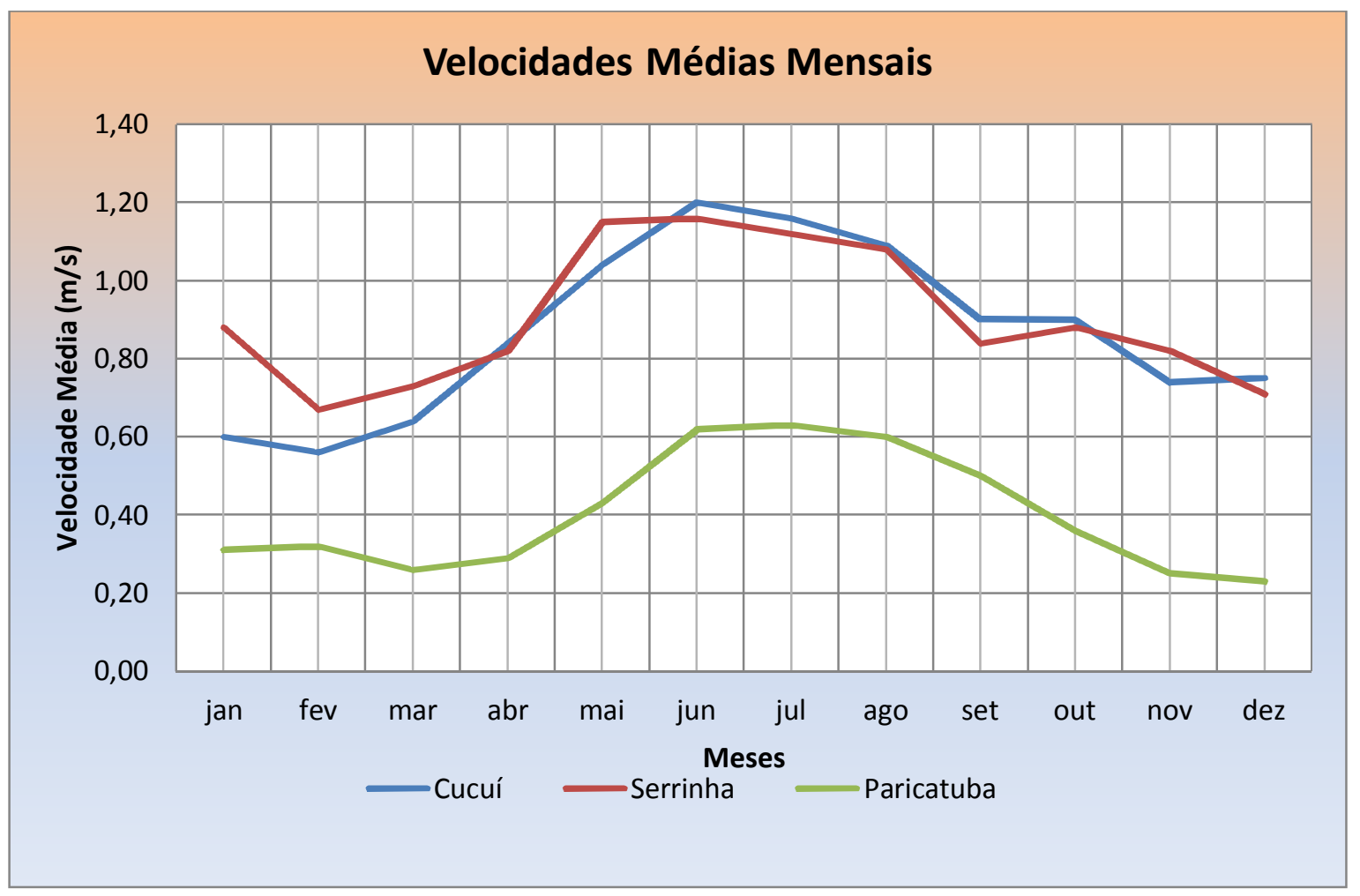

Figura 36: Comparação entre as Velocidades Médias Mensais medidas nas estações de Cucuí, Serrinha e Paricatuba.

Fonte: ANA e CPRM

Elaboração: ALVES (2012)

As velocidades médias mensais nas estações de Cucuí, Serrinha e Paricatuba apresentam comportamento anual semelhante às vazões medidas nestas mesmas estações, ou seja, apresentam máximas durante o período de águas altas que vai de maio a agosto, e mínimas durante o período de águas baixas. Apesar das vazões elevadas as velocidades médias não ultrapassam $1 \mathrm{~m} / \mathrm{s}$, fator que contribui para o tipo de carga em suspensão transportada e depositada pelo rio Negro na área de pesquisa, constituída predominantemente partículas do tamanho silte e argila. O uso do Diagrama de Hjulstrom (Figura 37) mostra que, em Anavilhanas, predominam processos de transporte dos sedimentos finos em suspensão durante o ano hidrológico cujas velocidades médias, medida em Paricatuba, é de 0,40 m/s. No período de cheias o rio atinge velocidades de até $0,65 \mathrm{~m} / \mathrm{s}$ capaz de transportar as areias muito finas $(0,125-0,062 \mathrm{~mm})$, que são depositadas nas ilhas do Complexo de Anavilhanas durante a descida das águas. 


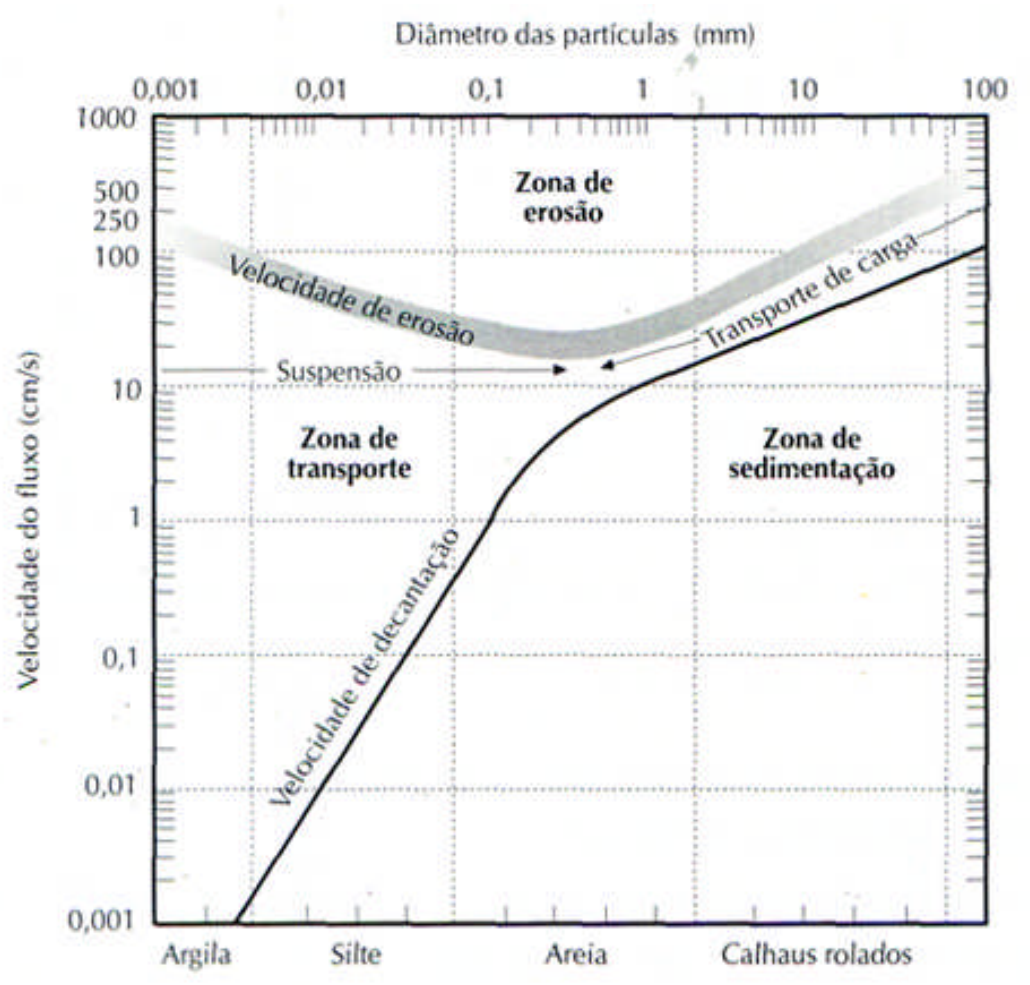

Figura 37: Diagrama de Hjulstrom

Fonte: http://rusoares65.pbworks.com

O uso do diagrama vem contribuir para a tese de que na área do complexo predominam baixas taxas de erosão e sedimentação. Para um predomínio de processos erosivos seriam necessárias velocidades de fluxo maiores; e para a deposição do material do tamanho silte e argila seriam necessários velocidades mais baixas, situação observada apenas nos lagos durante o período de vazante quando ocorre $\mathrm{o}$ isolamento destes $\mathrm{e}$ consequentemente a deposição dos finos.

A análise das cotas medidas no rio Negro e sua variabilidade anual serão analisadas no item a seguir: Análise da Dinâmica Anual e da Magnitude de Enchentes e Vazantes do Rio Negro no período de 1902-2010. 


\subsection{ANÁLISE DA DINÂMICA ANUAL E DA MAGNITUDE DE ENCHENTES E VAZANTES DO RIO NEGRO NO PERÍODO DE 1902-2010}

Baseando-se na bibliografia disponível, tal como em Filizola et al. (2002); Meade et al. (1991); Junk et al. (1989); Nunes de Mello e Barros (2001); em dados de cotas do rio Negro fornecidos pelo Porto de Manaus e em relatórios de monitoramento dos níveis d'água do sistema Solimões/Negro/Amazonas (CPRM, 2010/2011) foi realizada análise buscando compreender e caracterizar a dinâmica e magnitude de enchentes e vazantes do rio Negro no período de 1902-2010. Os objetivos específicos desta etapa foram: caracterizar os regimes anuais de vazões identificando-se eventos extremos, caracterizar a variabilidade anual das cotas fluviais mínimas e máximas, e compreender a relação entre as amplitudes destas cotas, sua dinâmica anual e as unidades morfológicas mapeadas. Além disto, procurou-se estabelecer relações entre estes dados e o efeito de barramento que o rio Solimões exerce sobre a hidrodinâmica do baixo curso do rio Negro.

O pulso de cheias e de inundações do Rio Negro deve-se a um amplo espectro de condições geomorfológicas, de distribuição espacial e temporal das precipitações e de condições hidrológicas de sua bacia hidrográfica, assim como da própria bacia do Rio Solimões, podendo estas cheias e inundações variarem em frequência, magnitude e duração. A alternância entre fases terrestres e aquáticas das formas fluviais ao longo do tempo e do espaço podem se dar em áreas marginais florestadas, pelo transbordamento lateral de águas dos rios ou, ainda dos lagos ou furos aos quais esses ambientes estão associados (JUNK et al., 1989), dentre outras formas possíveis. Importa reconhecer a distribuição temporal e espacial das fases hidrodinâmicas de enchimento e de esvaziamento no ano hidrológico, os principais vetores dos fluxos relacionados a esta dinâmica anual, a magnitude das cotas que podem ser alcançadas e duração destas fases, para relacioná-los à morfologia mapeada em Anavilhanas.

As cheias fluviais na Amazônia, com ressalvas para o fato de que possam apresentar maior ou menor amplitude, é um fenômeno natural que faz parte da dinâmica dos rios da região. São cheias que podem apresentar um longo tempo de duração, devido ao gigantesco tamanho da bacia hidrográfica, aos índices de precipitação, e à pequena declividade observada nos leitos dos seus principais corpos d'águas. Isto permite a sua previsibilidade com vários dias de antecedência. As próprias cheias de magnitudes consideradas potencialmente danosas, cujas frequências situam-se em torno de intervalos de recorrência de onze anos, podem 
também serem creditadas à vastidão da bacia hidrográfica e à sua pequena declividade (CPRM, 2010).

As cotas do rio Negro vêm sendo medidas, diariamente, desde setembro de 1902. Considerado um dos mais antigos e eficientes serviços de medição do nível dos rios amazônicos, foi criado pela companhia inglesa Manaos Harbour Limited, então exploradora do Porto de Manaus. Desde 1989, o Serviço Geológico do Brasil, realiza o Alerta de Cheias em Manaus, com o monitoramento das cotas fluviais diárias medidas para o sistema Solimões/Negro/Amazonas. O acompanhamento da evolução das cheias e vazantes na Amazônia Ocidental, por meio deste monitoramento, é uma parceria com a Agência Nacional de Águas (ANA) e o Sistema de Proteção da Amazônia (SIPAM). Dentre as várias estações existentes na área da bacia do rio Negro, cinco estações de monitoramento foram selecionadas para esta análise: as estações de São Gabriel da Cachoeira (14320001) no município de São Gabriel da Cachoeira, Tapuruquara (14400000) no município de Santa Isabel do Rio Negro, Barcelos (14480002) e, Moura (14840000) no município de Barcelos e Manaus (14990000) no município de Manaus (Figura 38).

A altitude inicial determinada para o Porto de Manaus, levando-se em conta o nível médio do mar, foi de uma centena de metros, valor que perdurou até 1971, quando foi introduzido o fator de correção de 60,61 m (NUNES DE MELLO; BARROS, 2001). As cotas medidas no Porto de Manaus são valores associados a uma referência de nível local e arbitrária, válida para a régua linimétrica da estação. Para comparação com as altitudes em Manaus, deveriam ser subtraídos 3,96m às cotas lidas na régua. Essa diferença deveria ser considerada no cálculo das cotas diárias medidas no Porto de Manaus para se ter dados de cotas absolutas e não relativas ao zero hidráulico. Moreira (2010), a partir de satélites altimétricos e uso de receptores GNSS (Global Navigation Satellite System) ${ }^{6}$, calculou a altura elipsoidal do zero da régua ao longo do tempo para a estação fluviométrica do porto de Manaus utilizando informação de cotas e, obteve o valor de -18,5555 metros. Estas correções não foram aplicadas neste estudo, trabalhando-se com os dados originais da série histórica.

\footnotetext{
${ }^{6}$ Receptores GNSS (Global Navigation Satellite System) técnica adequada para a avaliação de dados altimétricos, sendo feita a partir de medições in situ nos locais de passagem dos satélites altimétricos e também a partir do nivelamento das estações fluviométricas próximas. Dessa forma, tanto a informação captada pelo satélite quanto o valor medido na estação in situ estariam sob a mesma referência altimétrica, sendo a tecnologia GNNS capaz de prover informações altimétricas no nível centimétrico (MOREIRA, 2010).
} 
Nunes de Mello e Barros (2001) realizaram levantamento das cotas diárias, medidas no Porto de Manaus, para o período de 1903-1999 e definiram as cinco maiores enchentes e as cinco maiores vazantes do período analisado. Identificaram também as cinco menores cotas de enchentes e as cinco menores cotas de vazantes e, finalmente, as cinco maiores e as cinco menores diferenças entre as enchentes e as vazantes ocorridas em um mesmo ano.

As cinco maiores cotas de enchentes, segundo este estudo, ocorreram, em: 09/06/1953 (29,69m), 14/06/1976 (29,61m), 03/07/1989 (29,42m), 18/06/1922 (29,35m) e 14/06/1909 $(29,17 \mathrm{~m})$.

As cinco maiores cotas de vazante aconteceram em: 31/10/1963 (13,65m), 13/11/1906 (14,20m), 04/11/1997 (14,34m), 07/10/1916 (14,42m) e 13/10/1926 (14,54m).

Os cinco menores valores de cotas máximas foram: 07/07/1926 (21,77m), 22/06/1912 (24,84m), 24/05/1992 (25,42m), 14/07/1964 (25,91m) e 03/07/1980 (26,00m).

As cinco maiores amplitudes anuais das cotas fluviais no período analisado pelos autores foram: 1997 (14,62m), 1909 (14,13m), 1953 (12,62m), 1952 (12,44m) e 1916 (12,21m) e as cinco menores amplitudes: 1912 (05,45m), 1968 (06,10m), 1985 (06,53m), $1974(06,62 \mathrm{~m})$ e $1986(06,74 \mathrm{~m})$.

De acordo com dados da CPRM (2010) a média histórica das cotas fluviométricas máximas do rio Negro em Manaus (média das máximas) é de 27,81m, com desvio padrão de 1,13m. A máxima absoluta (junho de 2009) foi de 29,77m, a mínima absoluta (outubro de 2010) foi de 13,63m e a média das mínimas de $17,58 \mathrm{~m}$.

Segundo relatório de monitoramento da CPRM, o histórico das cheias do sistema Negro/Solimões obtidos em Manaus, para o período de 1902-2010 apresenta o seguinte quadro das cinco maiores cheias registradas: 01/07/2009 (29,77m), 09/06/1953 (29,69m), 14/06/1976 (29,61m), 03/07/1989 (29,42m), 18/06/1922 (29,35m). A cheia de 2009 (29,77m) ultrapassou a maior cheia até então registrada, que era a de 1953 (29,69m) (Quadro 9). 


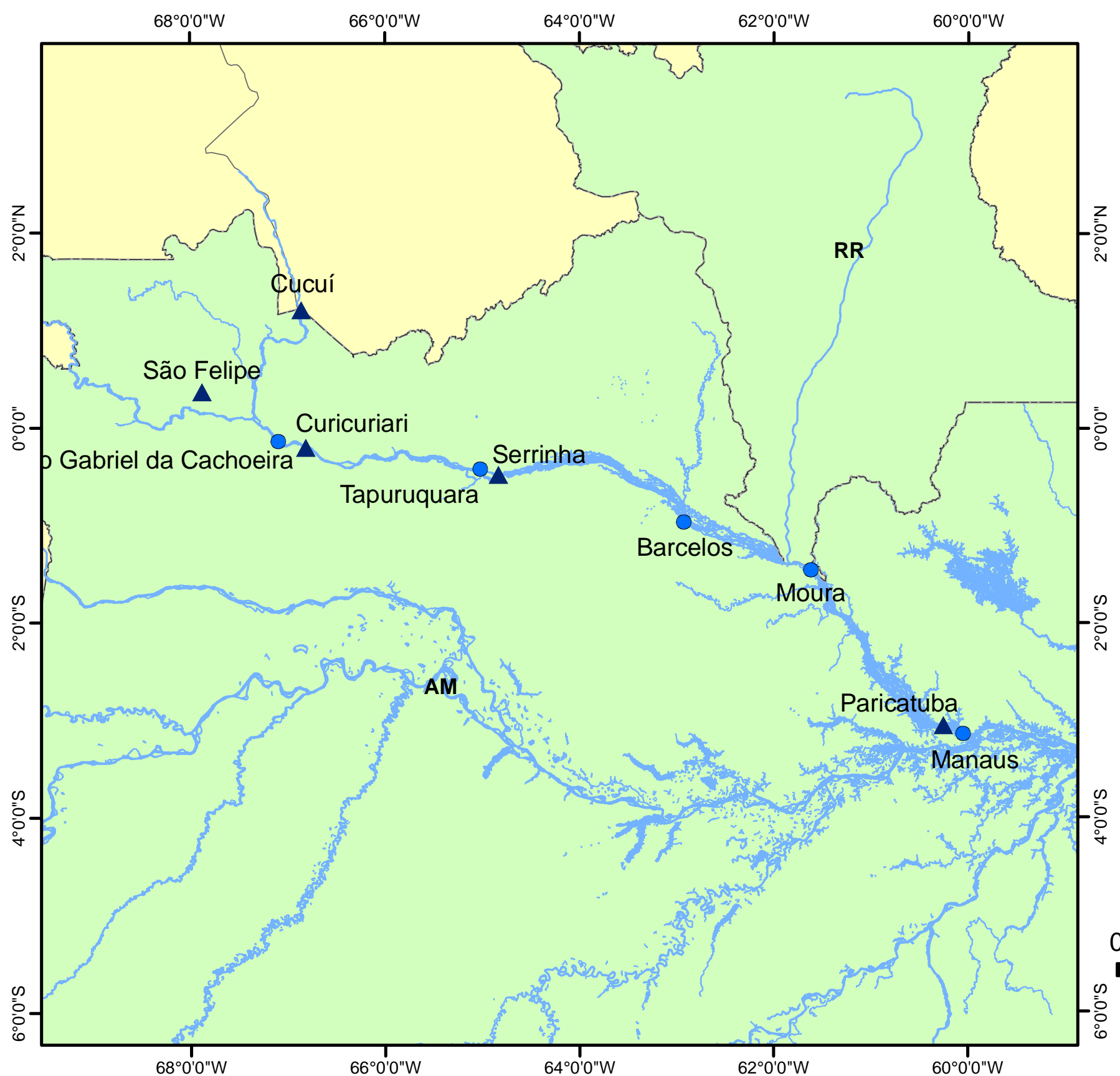

Figura 38: Estações fluviométricas do Rio Negro
ESTAÇÕES FLUVIOMÉTRICAS

\section{LEGENDA}

A Estações Hidrológicas - Vazão

- Estações Hidrológicas - Cota

Hidrografia

Unidades da Federação - Brasil

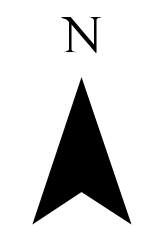

$1: 7.000 .000$

$300 \quad 450$

600

Datum SAD 69 Coordenadas LAT/LONG IBGE (2006) 
No Porto de Manaus em 2010, a CPRM registrou a vazante histórica do Rio Negro. As cinco maiores vazantes registradas para o período de 1902-2010 são: 24/10/2010 (13,63m), 30/10/1963 (13,64m), 13/11/1906 (14,20m), 04/11/1997 (14,34m), 07/10/1916 (14,42m).

Quadro 9: Dados das Cotas do Rio Negro na Estação de Manaus no período de 1902-2010.

\begin{tabular}{|c|c|c|c|c|c|}
\hline Ano & $\begin{array}{c}\text { Cota Máxima } \\
\text { Enchente }(\mathbf{m})\end{array}$ & Data & Ano & $\begin{array}{c}\text { Cota Máxima } \\
\text { Vazante }(\mathbf{m})\end{array}$ & Data \\
\hline 2009 & 29,77 & $01 / 07$ & 2010 & 13,63 & $24 / 10$ \\
\hline 1953 & 29,69 & $09 / 06$ & 1963 & 13,64 & $30 / 10$ \\
\hline 1976 & 29.61 & $14 / 06$ & 1906 & 14,20 & $13 / 11$ \\
\hline 1989 & 29,42 & $03 / 07$ & 1997 & 14,34 & $04 / 11$ \\
\hline 1922 & 29,35 & $18 / 06$ & 1916 & 14,42 & $07 / 10$ \\
\hline
\end{tabular}

Fonte: CPRM, 2011

Organizado por ALVES, 2011

Na série histórica das cotas diárias de Manaus, 76\% apresentaram o valor máximo anual no mês de junho, $19 \%$ em julho e $6 \%$ em maio e $43 \%$ tiveram o valor mínimo anual no mês de outubro, $35 \%$ em novembro, $10 \%$ nos meses de janeiro a dezembro e $1 \%$ nos meses de fevereiro e setembro (CPRM, Boletim n² 21, 22/06/2011).

Em Manaus, as cotas do rio Negro apresentam amplitudes máximas anuais de até 15-16 metros com uma média de aproximadamente $11 \mathrm{~m}$. Em Barcelos, distando $470 \mathrm{~km}$ à montante, a amplitude média das cotas é de 6,6 m, e em São Felipe localizado a cerca de 1000 km da confluência (Figura 38), a média de oscilação é de 7,5 m (LATRUBESSE; FRANZINELLI, 2005, p.382).

Neste estudo a amplitude anual das cotas (diferença entre as cotas máximas e mínimas) medidas para a estação de Manaus, no rio Negro é de 10 a 11 metros considerando o período de 1902-2010 (Figura 39), corroborando com os estudos de Latrubesse e Franzinelli (2005). 


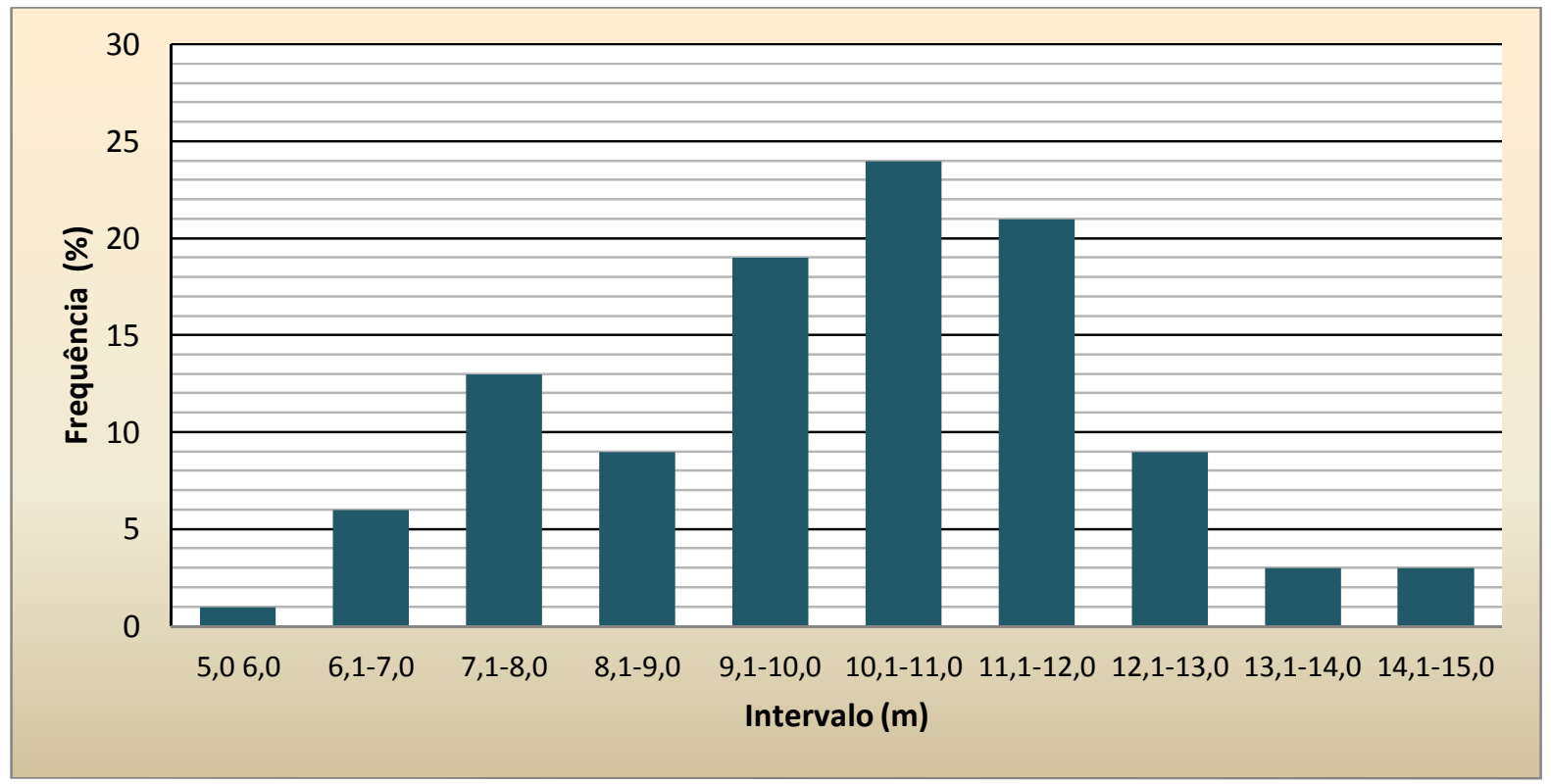

Figura 39: Frequência dos eventos segundo amplitudes anuais das cotas medidas no Porto de Manaus no período de 1902-2010

Elaboração: ALVES (2011)

O quadro abaixo (Quadro 10) apresenta dados históricos de eventos extremos de cheias e vazantes das estações de monitoramento na bacia do Rio Negro para o período de 1902 a 2010:

Quadro 10: Dados das cotas nas Estações de Monitoramento Hidrológico na bacia do Rio Negro no período de 1902-2010

\begin{tabular}{|l|c|c|c|c|}
\hline Estação & Maior cheia & Maior vazante & $\begin{array}{c}\text { Máxima } \\
\text { absoluta (m) }\end{array}$ & $\begin{array}{c}\text { Mínima } \\
\text { absoluta (m) }\end{array}$ \\
\hline $\begin{array}{l}\text { São Gabriel da } \\
\text { Cachoeira - 1432001 }\end{array}$ & 2002 & 1992 & 12,17 & 3,30 \\
\hline $\begin{array}{l}\text { Tapuruquara } \\
14400000\end{array}$ & 1976 & 1980 & 8,90 & 0,28 \\
\hline Barcelos - 14480002 & 1976 & 1980 & 10,32 & 0,58 \\
\hline Moura - 14840000 & 1989 & 2009 & 15,44 & 2,35 \\
\hline Manaus - 14990000 & 2009 & 2010 & 29,77 & 13,63 \\
\hline
\end{tabular}

Fonte: CPRM, 2011

Organizado por ALVES (2011)

As maiores cheias do rio Negro medidas nas estações de Tapuruquara e Barcelos apresentaram as seguintes cotas: Tapuruquara $(8,90 \mathrm{~m})$ e Barcelos $(10,32 \mathrm{~m})$, e a estação de Moura registrou sua maior enchente em 1989 (15,44m).

Em relação às maiores vazantes medidas na bacia do rio Negro observa-se que as estações de Tapuruquara e Barcelos apresentaram maior vazante em 1980, e as seguintes cotas: 
0,28m em Tapuruquara e 0,58m em Barcelos. Estas estações apresentam comportamento hidrológico semelhante, com cheias e vazantes máximas registradas, respectivamente, em 1976 e 1980, e valores de cotas máximas e mínimas bastante próximas.

A estação de Moura, mais próxima a Manaus, apresentou maior vazante $(2,35 \mathrm{~m}) \mathrm{em}$ 2009. A segunda maior vazante registrada (2,68m) no ano de 1997 coincide com a quarta maior vazante registrada no rio Negro em Manaus (14,34). É interessante observar que as máximas das cheias e vazantes registradas na estação de Moura, a exceção de 2009, coincidem com as quatro maiores cheias e vazantes registradas no Porto de Manaus.

A estação de São Gabriel da Cachoeira apresenta comportamento completamente distinto das estações localizadas nos cursos médio e inferior do rio Negro.

Esta análise preliminar, baseada nos dados de cheias e vazantes das estações de monitoramento ao longo do rio Negro, evidencia que na região do baixo rio Negro as flutuações do nível de água são regidas, em sua maior parte, pelo volume de água do Rio Solimões, que provoca o represamento de suas águas na região denominada "Encontro das águas", determinando assim a magnitude dos eventos extremos no Rio Negro em Manaus. Esse efeito de barramento hidráulico é tão intenso que é observado da foz até a sua confluência com o rio Branco, distante cerca de 300 quilômetros a montante. Assim, a partir da desembocadura do rio Branco, as flutuações do nível de água do rio Negro refletem principalmente as variações ocorridas no sistema Solimões-Amazonas. Sendo assim, para este estudo, voltado ao Complexo de Anavilhanas, dados de cotas medidas no Porto de Manaus podem ser utilizados para a análise do comportamento hidrológico ou da hidrodinâmica deste trecho do rio Negro. Soma-se a esta informação as observações e medidas das cotas fluviométricas em relação às ilhas durante as campanhas de campo realizadas durante os períodos de vazante de 2010-2011 e enchente de 2012. Estes levantamentos confirmaram as diferenças de cotas máximas e mínimas semelhantes às medidas no Porto de Manaus, nesta oportunidade. 


\subsection{EVENTO EXTREMO DO RIO NEGRO EM MANAUS EM 2012}

Em 16 de maio de 2012, a cota registrada do rio Negro, no porto de Manaus foi de 29,78 metros, superando a marca da cheia histórica de 2009 que foi de 29,77 metros (Figura 40). Em 29 de maio de 2012, no porto de Manaus, foi registrada a maior cheia histórica do rio Negro no período de 1903 a 2012 que atingiu a cota de 29,97 m (Quadro 11). O registro deste evento é mostrado nas figuras 41 a 45 .

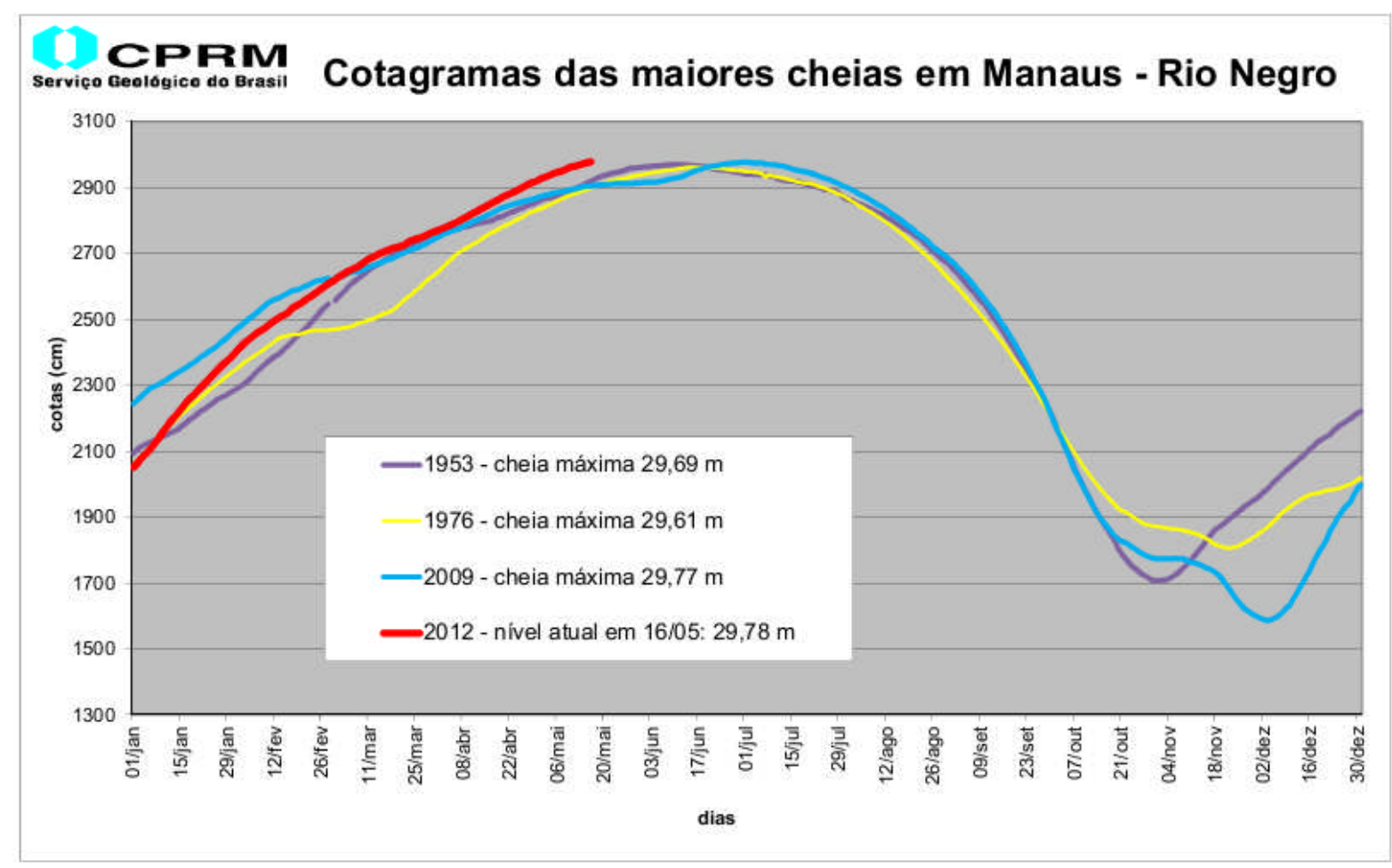

Figura 40: Cotagramas das maiores cheias em Manaus - Rio Negro

Fonte: CPRM (2012)

Quadro 11: Dados das Cotas do Rio Negro na Estação de Manaus no período de 1902-2012.

\begin{tabular}{|c|c|c|c|c|c|}
\hline Ano & $\begin{array}{c}\text { Cota Máxima } \\
\text { Enchente (m) }\end{array}$ & Data & Ano & $\begin{array}{c}\text { Cota Máxima } \\
\text { Vazante (m) }\end{array}$ & Data \\
\hline 2012 & 29,97 & $29 / 05$ & 2010 & 13,63 & $24 / 10$ \\
\hline 2009 & 29,77 & $01 / 07$ & 1963 & 13,64 & $30 / 10$ \\
\hline 1953 & 29,69 & $09 / 06$ & 1906 & 14,20 & $13 / 11$ \\
\hline 1976 & 29.61 & $14 / 06$ & 1997 & 14,34 & $04 / 11$ \\
\hline 1989 & 29,42 & $03 / 07$ & 1916 & 14,42 & $07 / 10$ \\
\hline
\end{tabular}

Fonte: Porto de Manaus, 2012

Organizado por ALVES (2012) 
De acordo com o Serviço Geológico do Brasil (CPRM) em citação já feita neste trabalho, na série histórica das cotas em Manaus 75\% tiveram o seu valor máximo anual no mês de junho, 19\% em julho e 6\% em maio (Figura 41). Em 2012 a cota máxima anual foi atingida em maio, mês de menor frequência observado na série histórica das cotas do rio Negro medidas no porto de Manaus.

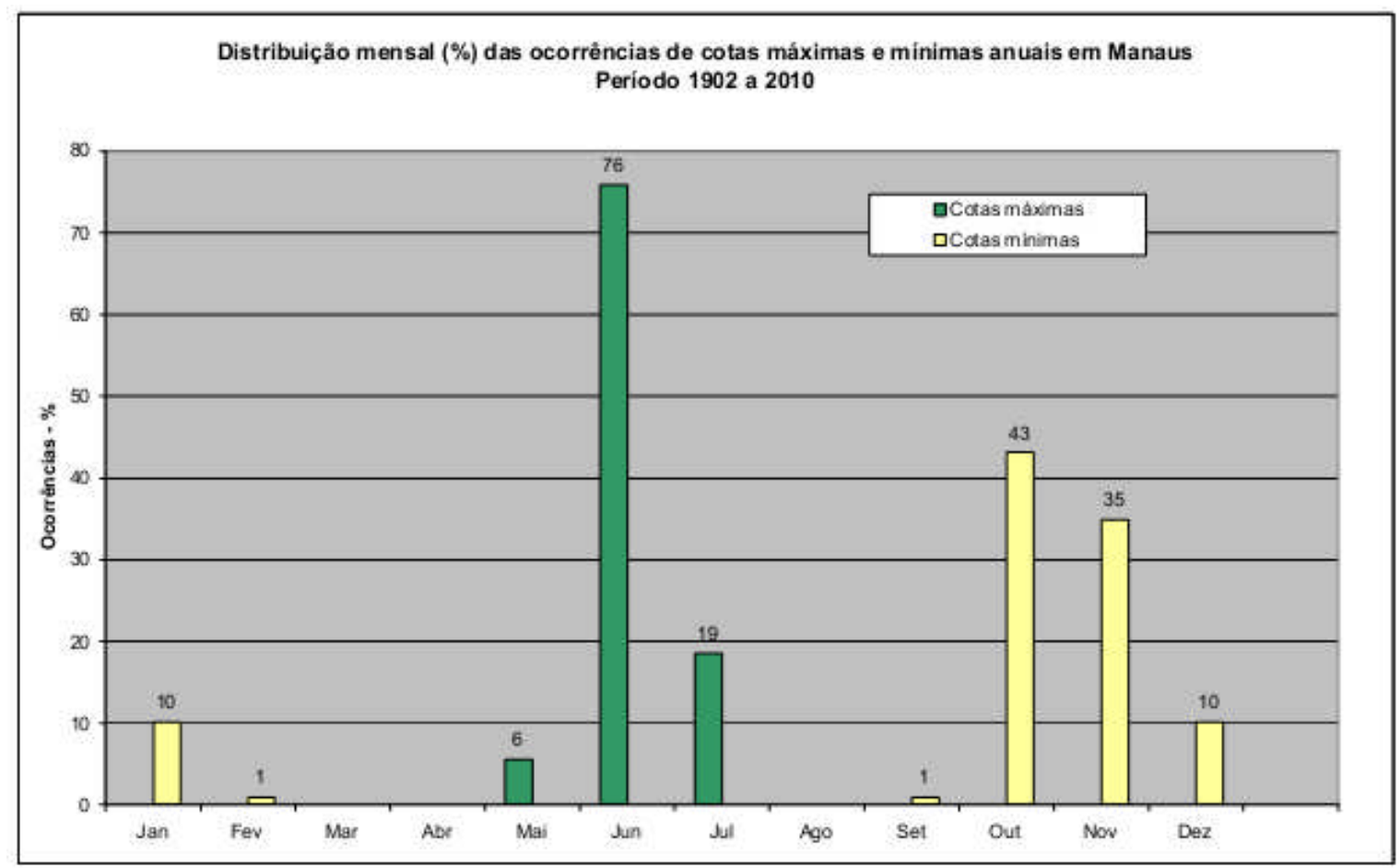

Figura 41: Distribuição histórica (\%) de cotas máximas e mínimas do Rio Negro em Manaus (atualizado até 2010)

Fonte: CPRM (2012)

Eventos de cheias extremas na bacia do Rio Negro diminuíram em tempo de recorrência e ampliaram suas intensidades conforme pode ser observado no Quadro 12. O que se observa é, de uma maneira geral, um aumento de eventos extremos em diversas seções da bacia Amazônica registrados em menores intervalos de tempo, associados à intensificação dos fenômenos de vazante ou de enchente.

Um aumento da frequiência de eventos hidrológicos extremos na bacia amazônica é observado desde o final dos anos 80, que é coerente com a hipótese de que as secas extremas podem tornar-se mais frequentes e intensas por causa das mudança climáticas (ESPINOZA et al., 2009). 
Quadro 12: Histórico das cheias do sistema Negro/Solimões em Manaus

\begin{tabular}{|c|c|c|c|c|c|c|}
\hline \multirow{2}{*}{$\begin{array}{c}\mathbf{N}^{\circ} \text { Ordem } \\
\end{array}$} & \multirow{2}{*}{ Ano } & \multicolumn{3}{|c|}{ Evolução do Processo } & \multirow{2}{*}{$\begin{array}{c}\text { Pico da } \\
\text { cheia (m) }\end{array}$} & $\begin{array}{c}\text { Tempo de } \\
\text { retorno (ano) }\end{array}$ \\
\cline { 3 - 5 } & & Início & Fim & $\mathbf{N}^{\circ}$ de dias & & \\
\hline $1^{\circ}$ & 2012 & $12 / 10 / 2011$ & $29 / 05 / 2012$ & 231 & 29,97 & 110 \\
\hline $2^{\circ}$ & 2009 & $30 / 10 / 2008$ & $01 / 07 / 2009$ & 244 & 29,77 & 55 \\
\hline $3^{\circ}$ & 1953 & $31 / 10 / 1952$ & $09 / 06 / 1953$ & 221 & 29,69 & 36,6 \\
\hline $4^{\circ}$ & 1976 & $30 / 11 / 1975$ & $14 / 06 / 1976$ & 197 & 29.61 & 27,5 \\
\hline $5^{\circ}$ & 1989 & $15 / 10 / 1988$ & $03 / 07 / 1989$ & 261 & 29,42 & 22 \\
\hline
\end{tabular}

Fonte: Porto de Manaus, 2012

Organizado por ALVES (2012)

De acordo com Gupta (2011) as precipitações sobre a Bacia Amazônica são influenciadas por mudanças anuais da Zona de Convergência Intertropical (ZCIT) e da Zona de Convergência do Atlântico Sul (ZCAS) sobre a região Andina, e, tanto a precipitação como a vazão dos rios da bacia é afetada em determinados anos pelo El Niño Oscilação Sul (ENOS) e baixos fluxos do Amazonas estão associado com anos de El Niño (MERTES; DUNNE, 2007). Estas variabilidades climáticas afetam as inundações e sedimentação (AALTO et al., 2003 apud GUPTA, 2011) mas seu efeito na morfologia dos rios da Bacia Amazônica ainda devem ser compreendido.

É apontado como responsável por esse evento extremo no rio Negro o fenômeno La Niña, fenômeno oceânico-atmosférico com características opostas ao El Niño, e que caracterizase por um esfriamento anormal das águas superficiais do Oceano Pacífico Tropical, cujos impactos na região norte do Brasil inclui o aumento da precipitação e vazão dos rios. A cheia de 2009 também é atribuída a La Niña quando rio Negro atingiu a cota máxima de 29,77 m em Manaus.

As secas na Amazônia estão geralmente associadas a anomalias positivas da Temperatura da Superfície do Mar (TSM) no Atlântico tropical norte durante o outono e inverno austral, e uma posição anormal, ao norte, da ZCIT, que transporta ventos alísios fracos e vapor de água para a Bacia Amazônica. Eventos de El Niño podem também produzir condições de seca durante o verão austral, especialmente no nordeste da bacia e excepcionalmente na Amazônia Ocidental. Em contraste, durante La Niña, abundantes precipitações e inundações ocorrem durante o verão austral no norte e nordeste da região amazônica. Além disso, o gradiente de TSM do Atlântico 
tropical meridional influencia a migração da ZCIT, e grandes anomalias positivas de TSM no Atlântico tropical sul, especialmente no final do verão e outono, podem produzir abundantes chuvas e inundações, como ocorreu em 2009, na Amazônia central (ESPINOZA et al., 2012).
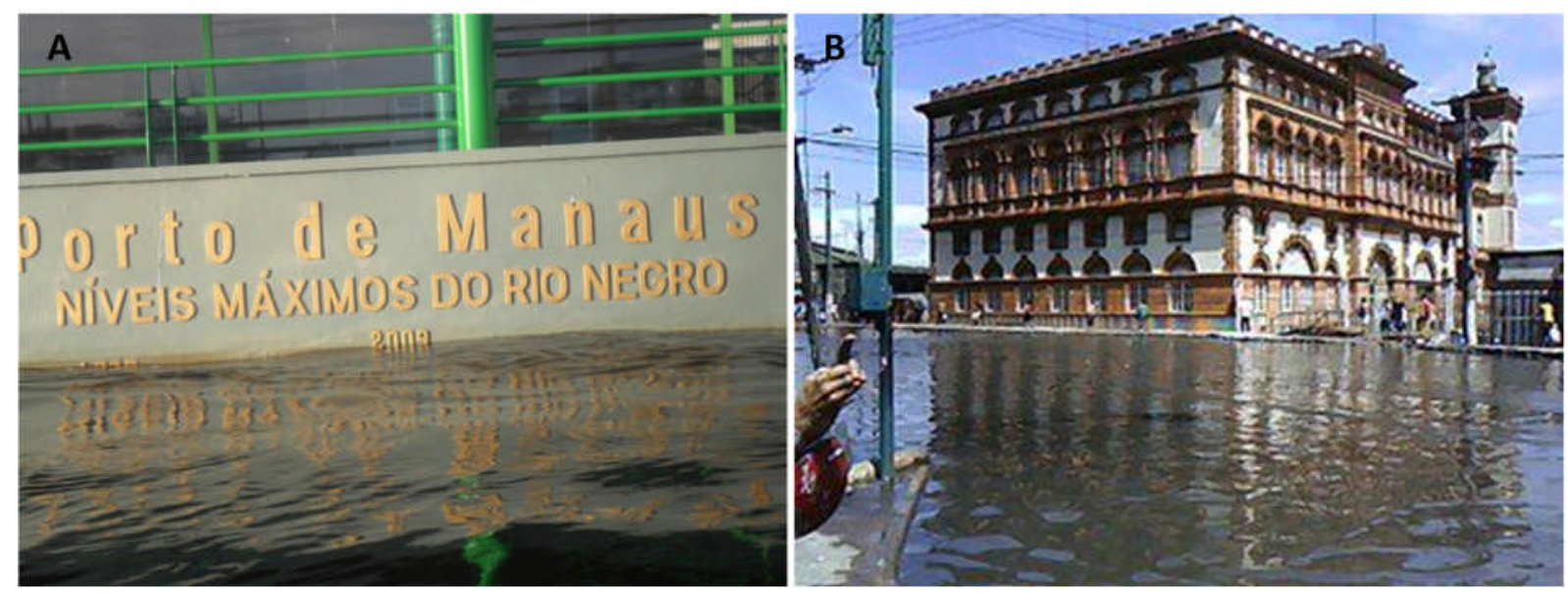

Figura 42: A: Porto de Manaus. Cota: 29,78. Data da foto: 16/05/2012. (Autor: Edaílza B. da Gama); B: Prédio da Alfândega em Manaus. Data da foto: 20/05/2012 (Fonte: internet). 

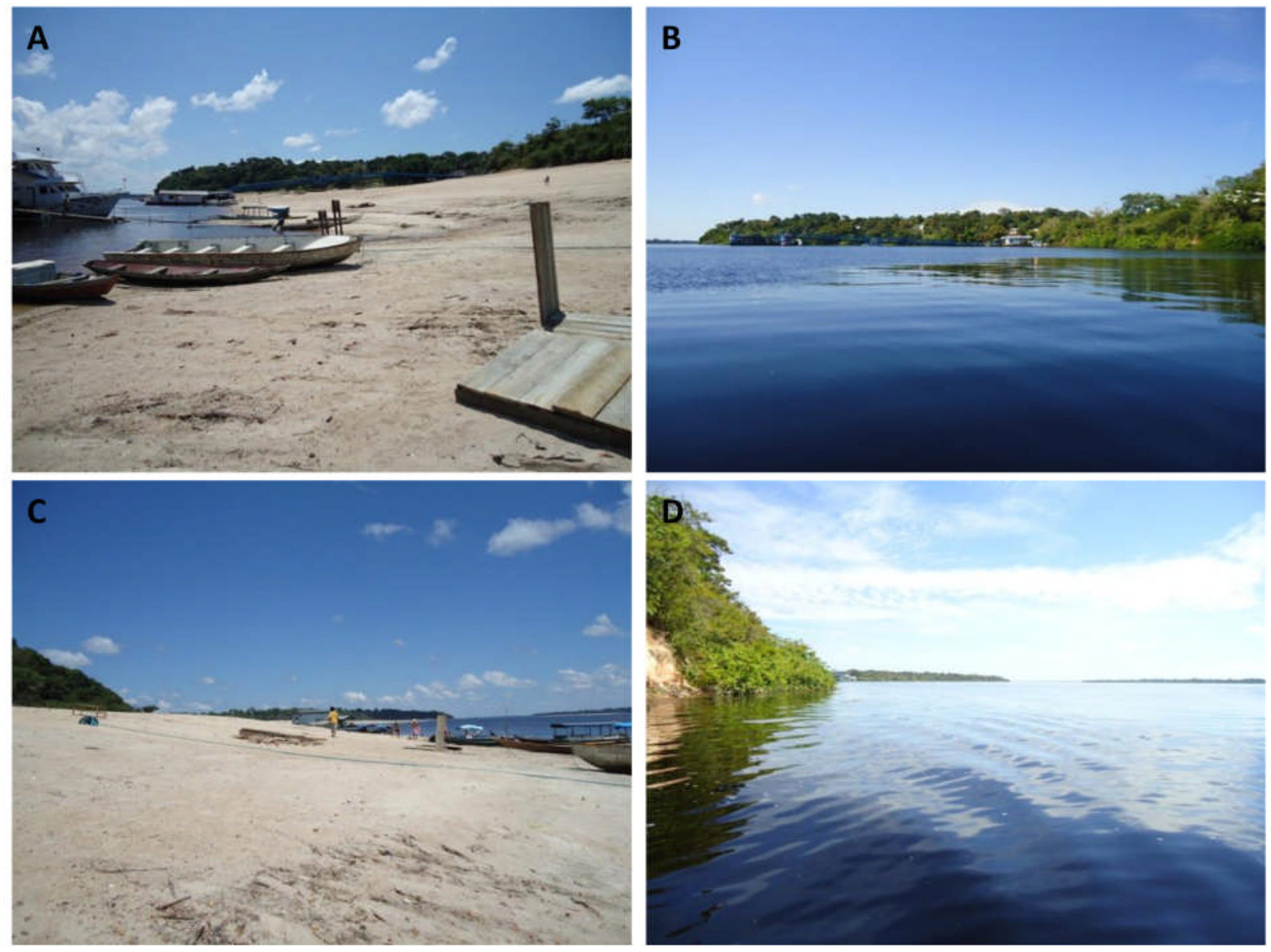

Figura 43: Praia de Novo Airão com porto flutuante ao fundo. A: vazante de 2010: cota do rio Negro em Manaus 30/10/2010: 13,85 m; B: cheia de 2012; cota do rio Negro em Manaus 17/06/2012: 29,61 metros. C e D: Praia de Novo Airão com vista para montante do arquipélago. C: vazante de 2010; D: cheia de 2012; cota do rio Negro em Manaus 17/06/2012: 29,61 metros. Diferença das cotas: $\mathbf{1 5 , 7 6}$ metros. (imagens da autora) 

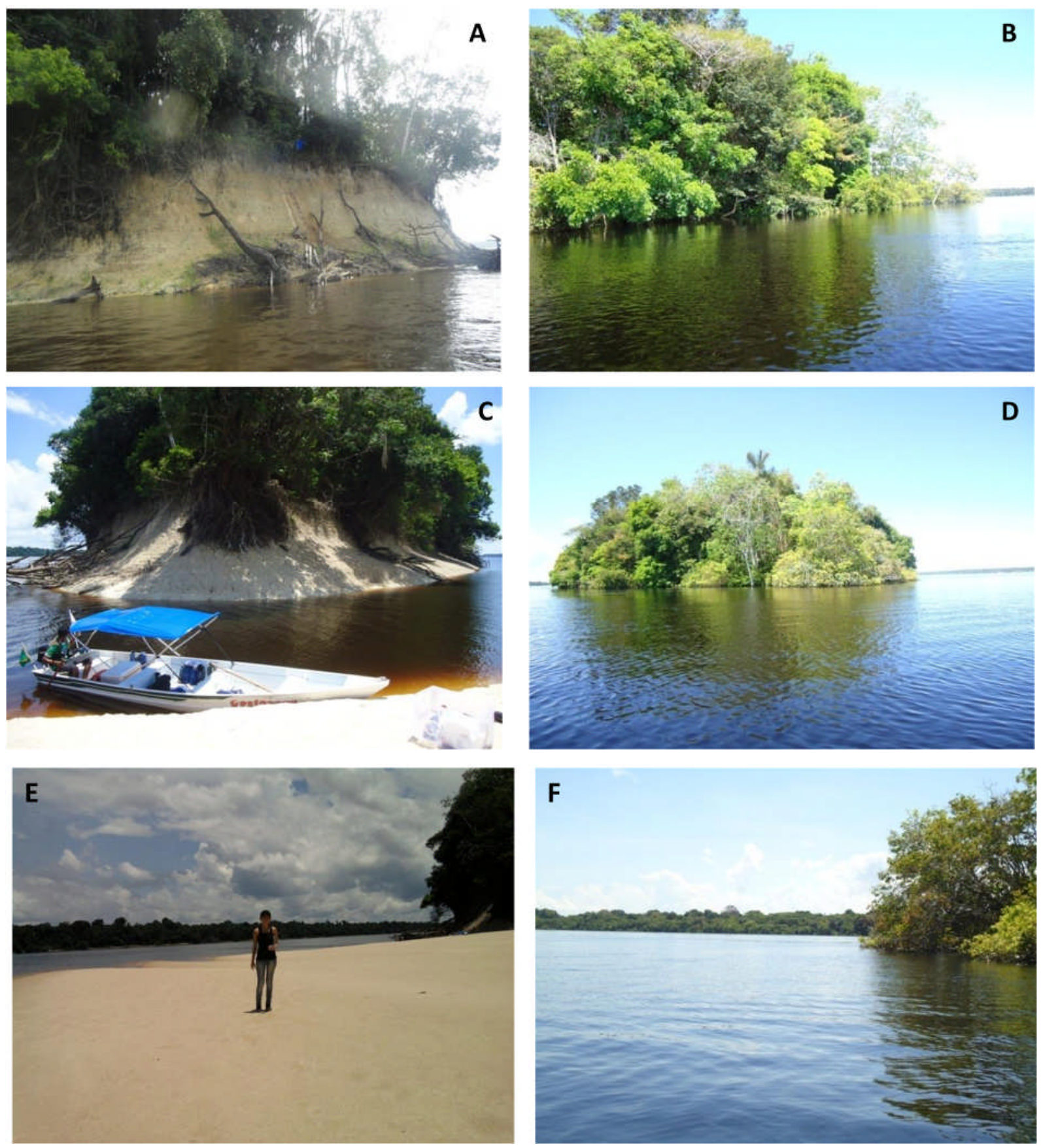

Figura 44: Promontório da Ilha Grande das Anavilhanas e Praia do Meio. A: Vazante de 2011. Cota do rio Negro em Manaus em 27/11/2011: 17,69 metros; B: Cheia de 2012. Cota do rio Negro em 17/06/2012: 29,61 metros. C: Vazante de 2011; D: Cheia de 2012; E: Praia do Meio, vazante de 2011; F: Praia do Meio; cheia de 2012. Diferença das cotas: 11,92 metros. Direção da tomada das fotos: A e B: NE-SW; C e B: NW-SE e E e F: aproximadamente N-S. (imagens da autora) 

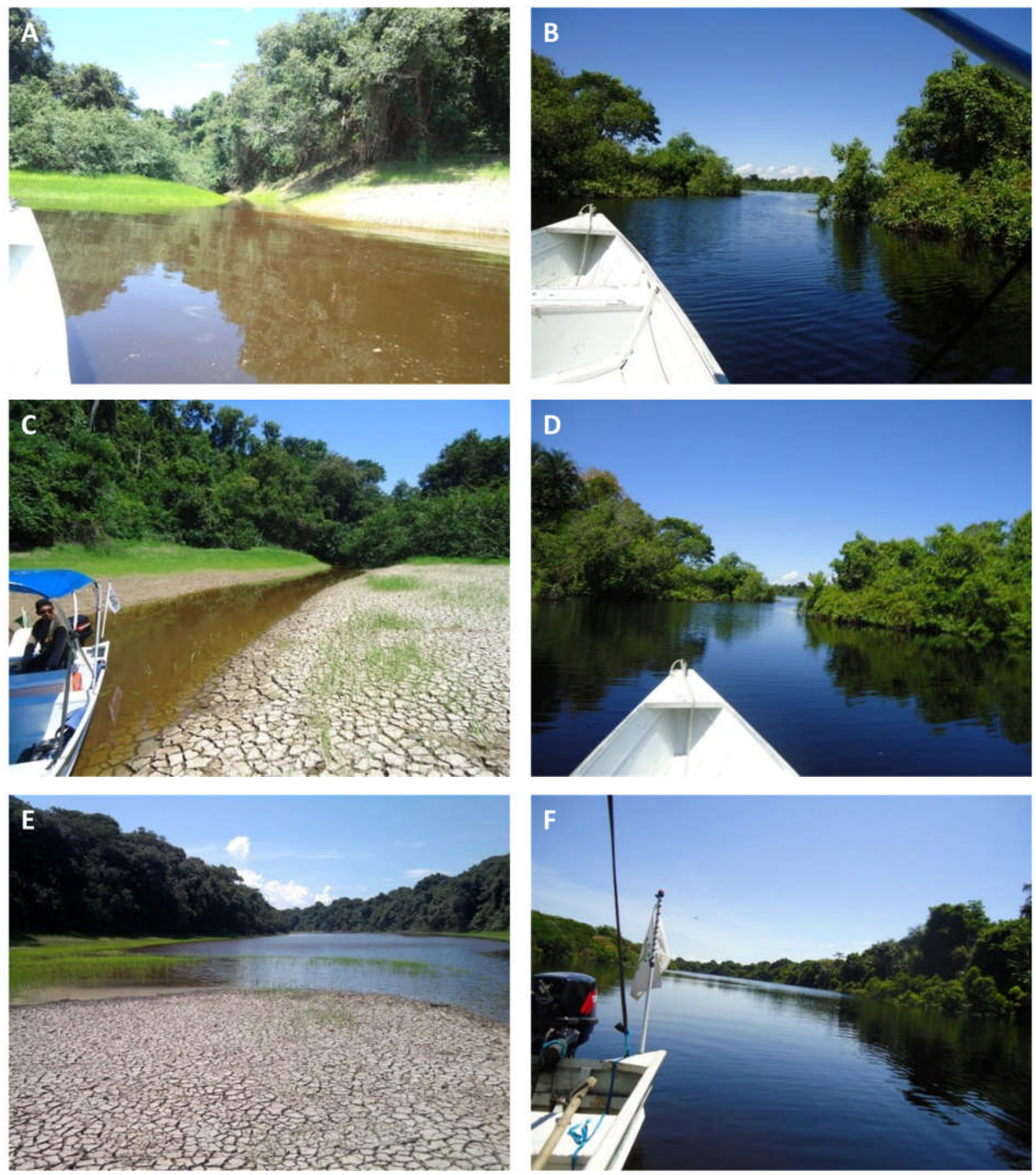

Figura 45: Entrada do Furo que liga Paraná ao Lago Tamatá. A: Imagem da vazante de 2011: cota do rio Negro em Manaus em 25/10/2011: 17,64 metros; B: Imagem da cheia de 2012: cota do rio Negro em Manaus em 17/06/2012: 29,61 metros; C e D: Mesmo local com vista do furo a partir do Lago Tamatá; C: Imagem da vazante de 2011; D: Imagem da cheia de 2012; E: Lago Tamatá, vazante de 2011; F: Lago Tamatá, cheia de 2012. Diferença das cotas: 11,97 metros. (imagens da autora) 

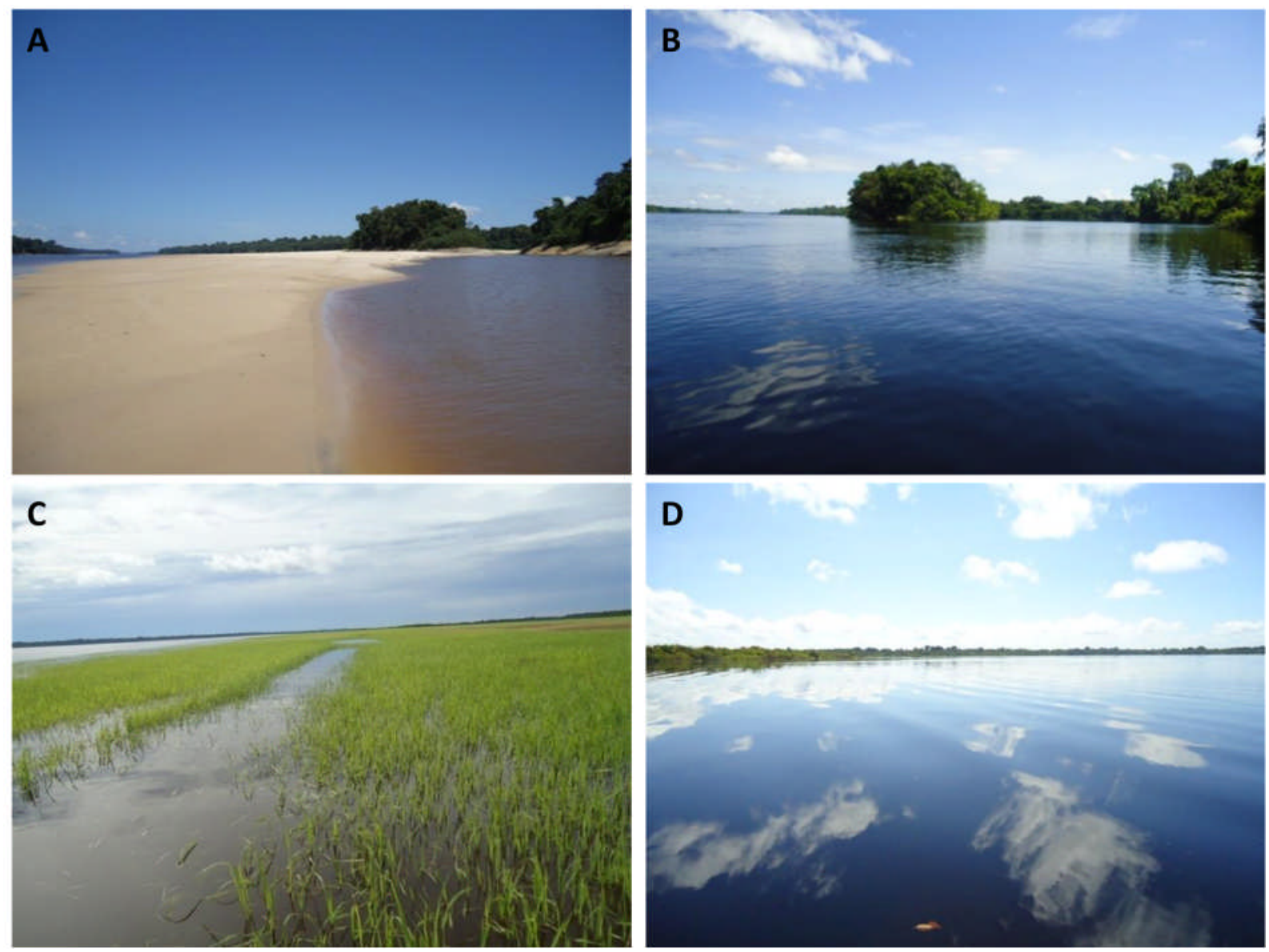

Figura 46: Praia do Sapato e Paraná do Sapato. A: vazante de 2010: cota do rio Negro em Manaus 30/10/2010: 13,85 m; B: cheia de 2012; cota do rio Negro em Manaus 17/06/2012: 29,61 metros. Diferença das cotas: 15,76 metros. C: Lago do Arraia, vazante de 2011 cota do rio Negro em Manaus em 26/10/2011: 17,67 metros; D: cheia de 2012 cota do rio Negro em Manaus em 17/06/2012: 29,61 metros. Diferença das cotas: 11,94 metros. (imagens da autora)

\subsection{CARACTERIZAÇÃO MORFOLÓGICO-MORFOMÉTRICA}

\subsubsection{Sistema Canal}

\subsubsection{O Complexo Fluvial de Anavilhanas}

As Unidades Morfológicas mapeadas na área do Complexo de Anavilhanas compreendem os sistemas de Canal, Planície de Inundação e Terra Firme. O sistema Canal inclui os subsistemas Ria (subdivididos em padrão anastomosado e padrão dendrítico), Barras Fluviais e Margens. O sistema Planície de Inundação inclui o subsistema Ilhas Fluviais (promontórios, diques longitudinais e lagos). O complexo anastomosado de Anavilhanas é composto por dois 
canais principais retos, canais secundários (paranás) retos ou de baixa sinuosidade e sinuosidade meandrante, e por furos que são pequenos canais retos.

Este complexo, do ponto de vista de uma visão de conjunto de seus aspectos morfológicos e morfométricos, foi considerado como pertencente a um grupo particular de padrão anastomosado, ou seja, o padrão anabranches, de acordo com a proposição de Nanson e Knigton (1996).

Para essa classificação, foram levantadas informações morfológico-morfométricas. O conjunto apresenta diversos padrões de canais internos, situação concordante com Bridge (1993) apud Knighton (1998). Esses canais estão assim distribuídos: perto de $13 \%$ é de padrão tendendo à retilíneo com índice de sinuosidade de 1,05; 61\% tendendo a apresentar baixa sinuosidade (Is. $1,07)$ e $26 \%$ apresentando alta sinuosidade (Is. 1,4).

\subsubsection{Ria - Padrão Anastomosado/anabranches}

Conforme dito anteriormente o padrão anastomosado consiste em um complexo de canais interconectados de baixa energia, relativamente profundo e estreito, com margens estáveis compostas por sedimentos de granulação fina (silte/argila) e vegetação. Separando os canais estão as planícies de inundação constituídas por ilhas de forma alongada e cobertas por vegetação, diques naturais e zonas úmidas e alagadas. Caracteriza-se pela baixa razão largura/profundidade do canal, a qual pode ser inferior a 10, e alta sinuosidade, superior a 2,0. Normalmente os detritos são transportados como carga em suspensão ou mista, embora estes rios possam transportar sedimentos grossos em abundância. A baixa declividade dos canais, bem como a sinuosidade, provoca frequentemente o extravasamento do canal e deposição de siltes e argilas (SMITH; SMITH, 1980 apud MIALL, 1996).

O padrão anabranches consiste em um padrão de canais múltiplos separados por ilhas aluviais estáveis, que dividem os fluxos de descargas até aproximadamente as margens plenas. As ilhas são estabilizadas pela vegetação e tem aproximadamente a mesma elevação (cota) da planície de inundação. O canal individual de um sistema anabranches pode ser retilíneo, meandrante ou entrelaçado e, este tipo de padrão de canal pode ocorrer em diversos tipos de 
ambiente, do subártico ao tropical, do monçônico ao semi-árido, portanto, não é o clima um fator determinante na sua formação (BRIDGE, 1993; SCHUMM, 1985 apud KNIGHTON, 1998).

Nanson e Knighton (1996) sugerem que o termo anastomosado seja limitado a um subconjunto específico de sistemas anabranches, de baixa energia, relativamente distintos associado à deposição de sedimentos finos ou matéria orgânica.

A maior parte dessas características morfológico-morfométricas aplica-se ao caso de Anavilhanas, classificando o sistema como Tipo 1: Rio anabranches com leito de sedimentos coesos (rios anastomosados) (NANSON; KNIGHTON, 1996), exceto quanto à razão largura/profundidade do canal principal, cujos valores alcançados são superiores a 10 e quanto a coesão dos materiais do leito fluvial.

\section{a) Canal Principal}

O rio Negro na área do Arquipélago de Anavilhanas subdivide-se em dois grandes canais laterais, um na esquerda e outro na extrema direita, ambos margeando a Terra Firme, no trecho conhecido regionalmente com Baixo Rio Negro (Figura 47). Estes dois canais voltam a formar um único canal, à jusante do arquipélago, nas proximidades do "encontro das águas" em Manaus. Estes canais apresentam uma largura média de até $2 \mathrm{~km}$, variável na região de montante, onde apresenta largura média de $1,5 \mathrm{~km}$, e na região de jusante próximo a Manaus, de até 4,0 km, índice de sinuosidade de 1,07, com valores de profundidade que varia de 22 a 18 metros no período de cheia e de 9 a 3 metros durante o período de vazante, apresentando amplitude anual entre as cotas de cheias e vazante de 11 metros. Os aspectos morfológicomorfométricos apontam para a classificação do padrão fluvial do canal do tipo anabranches com leito de sedimentos coesos (rio anastomosado) ou Tipo 1, de acordo com a classificação proposta por Nanson e Knighton (1996), com a formação de ilhas fluviais vegetadas e entrelaçadas por paranás. 


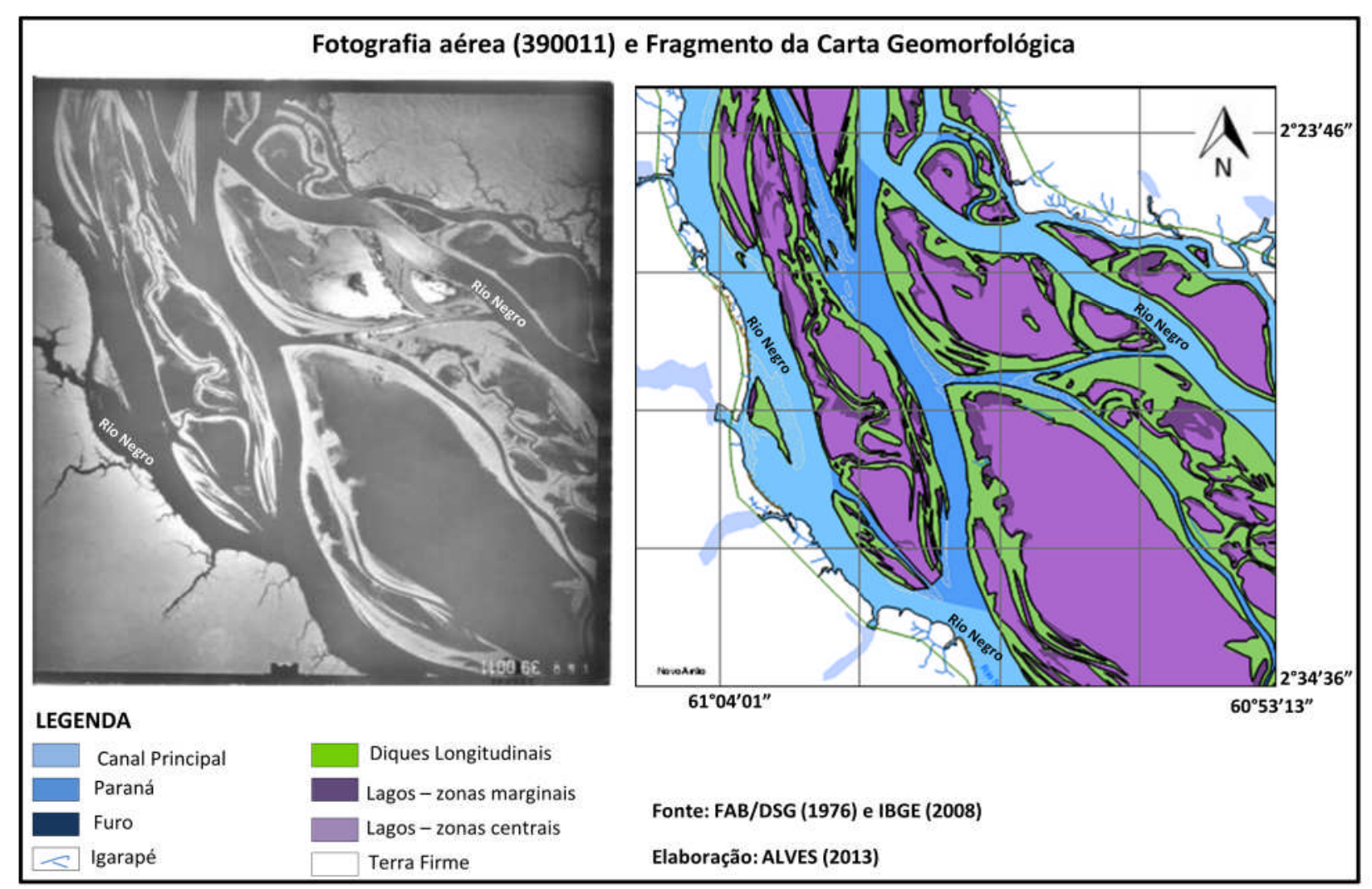

Figura 47: Ria - Padrão Anastomosado: Canal Principal do Rio Negro

\section{b) Paranás}

"Os paranás correspondem a todo o canal de drenagem que liga um rio a ele mesmo em áreas da planície aluvial ou, pelo menos, com uma margem ligada à planície aluvial" (CHRISTOFOLETTI, 1981 p. 153). O Paraná é um extenso, largo e profundo braço de rio (SOARES, 1977). Na área do complexo de Anavilhanas os paranás constituem os canais fluviais entre as ilhas, com cerca de $1 \mathrm{~km}$ de largura e sinuosidade com tendência retilínea com índice de 1,05. Também ocorrem no interior de grandes ilhas, sendo aí mais estreitos com larguras variáveis entre 100 a 200 metros. Apresentam uma profundidade média de 7 metros durante o período de vazante e de 9 a 10 metros durante as cheias anuais. Os paranás mais estreitos, os que seccionam as ilhas fluviais, mostram acentuada sinuosidade com índice de 1,4 formando pequenos meandros, a exemplo do Paraná da Lua localizado na Ilha Grande das Anavilhanas (Figura 48). 


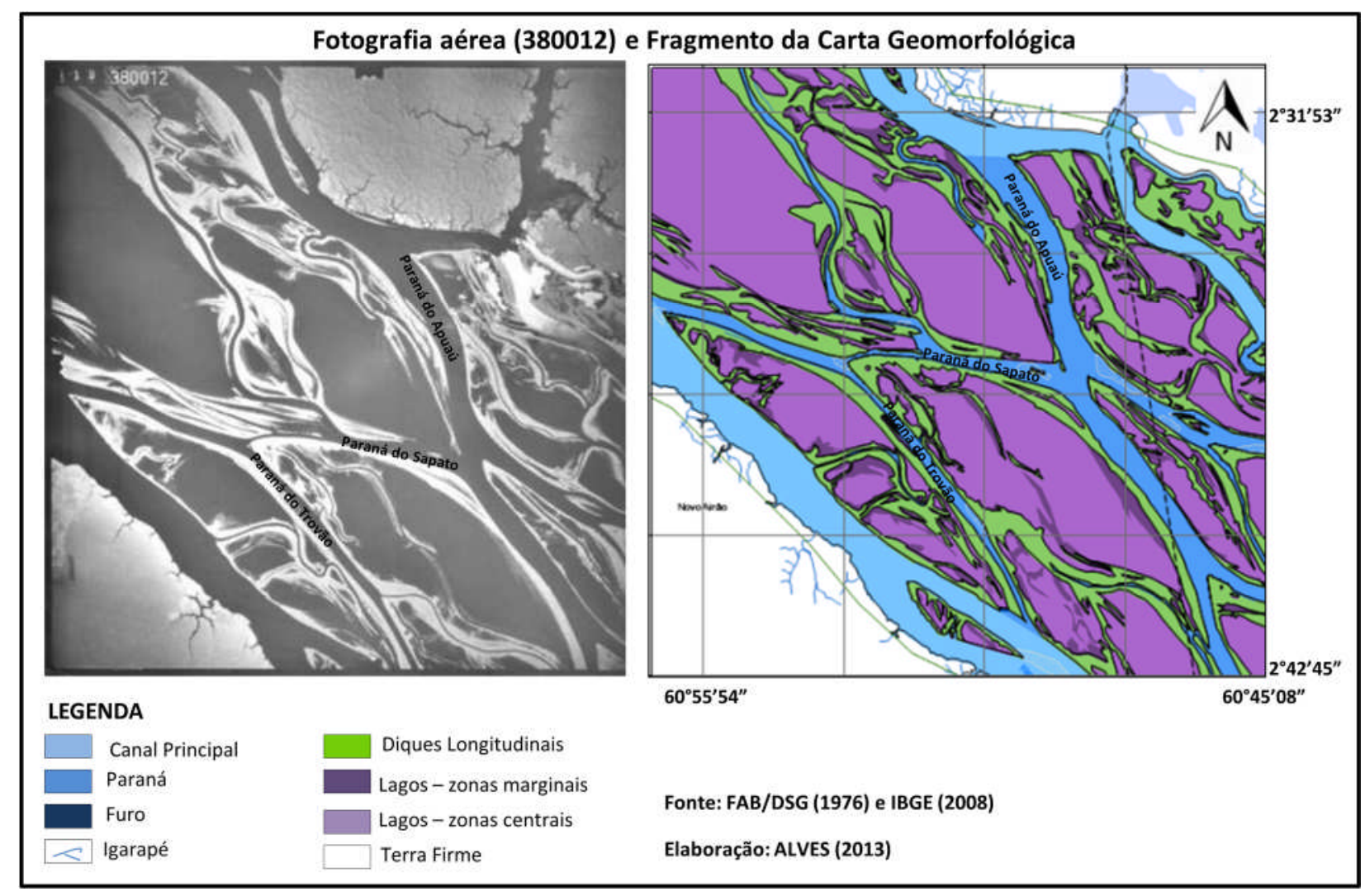

Figura 48: Ria - Padrão Anastomosado: Paranás

c) Furos

"O furo corresponde a todo o canal de drenagem que liga um rio a outro, um rio a um lago ou um rio a ele mesmo, sendo, neste último caso, fora da planície de inundação" (CHRISTOFOLETTI, 1981 p. 153). Segundo Ab'Saber (2003) o furo é sempre um canal fluvial sem correnteza própria, que secciona uma ilha fluvial ou interliga componentes internos de uma planície de inundação.

Em Anavilhanas existem furos que ligam um paraná a outro; furos que ligam um lago a um paraná; furos que ligam um lago ao canal principal; furos que ligam um lago a outro. Os furos normalmente são de pequena extensão $(200 \mathrm{~m})$, largura (2 a $3 \mathrm{~m})$ e profundidade $(1 \mathrm{~m})$, e muitos secam durante a vazante interrompendo a conexão entre os lagos e os paranás e/ou canal principal (Figura 49). Observa-se na área do complexo uma maior densidade de furos em sua área distal, com um predomínio de furos que ligam lagos ao canal principal e/ou a paranás. Os 
furos compreendem única conexão entre canais e lagos durante o período de vazante e apresentam direção de fluxo variável nestes períodos.

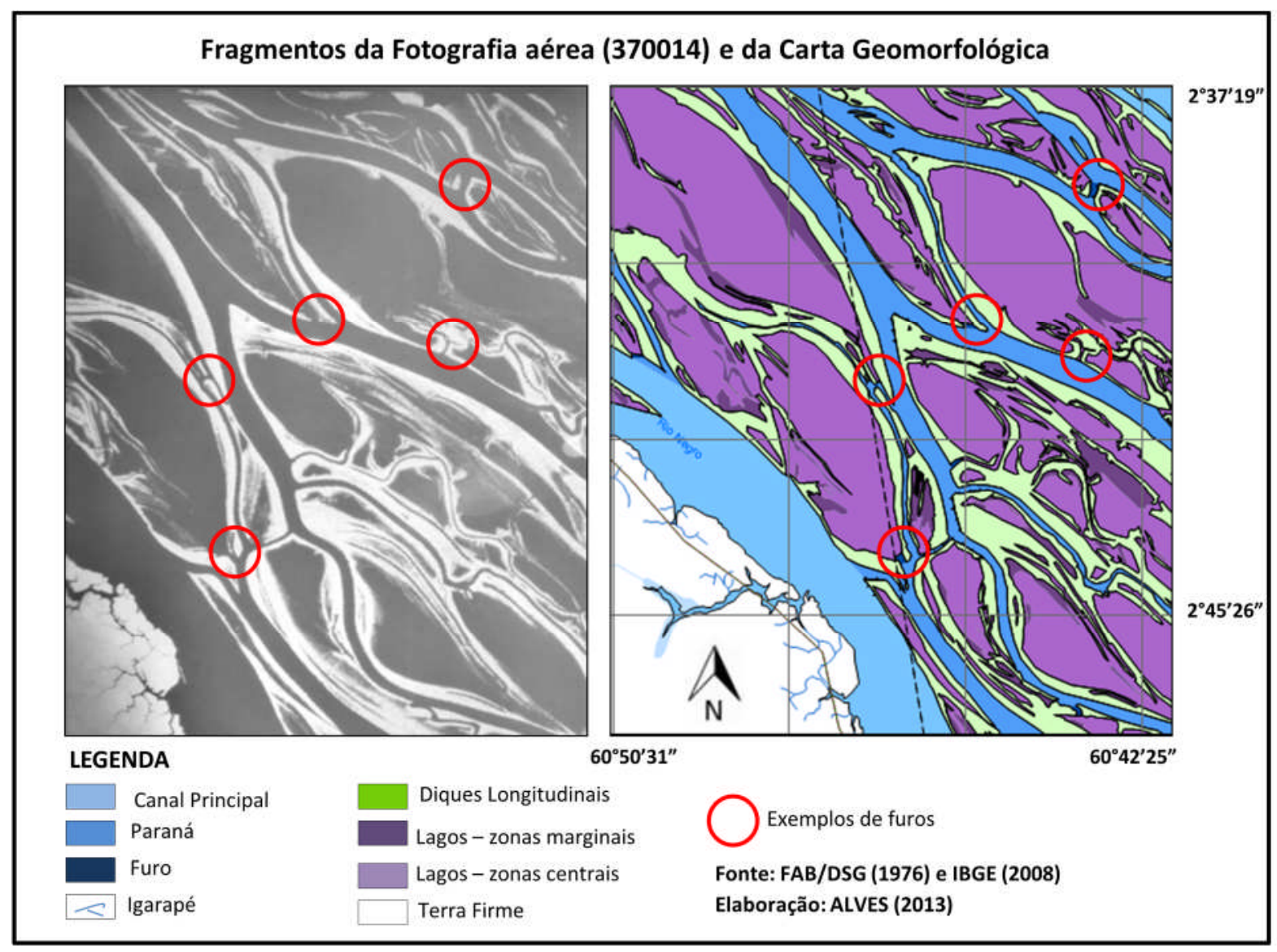

Figura 49: Ria - Padrão Anastomosado: Furos

\subsubsection{Ria - Padrão Dendrítico}

\section{a) Igarapés}

Os igarapés são cursos d'água amazônicos de primeira, segunda ou terceira ordem componentes primários de tributação de rios pequenos, médios e grandes (AB'SABER, 2003). $\mathrm{Na}$ área do Complexo de Anavilhanas os igarapés são os canais tributários do rio Negro, tanto da margem esquerda (com direção geral NE-SW) como da margem direita (direção geral SW-NE), destacando-se os igarapés Tarumã-Mirim e Tarumã-Açu na margem esquerda e os igarapés Freguesia, Açu e Tumbira na margem direita. Estes igarapés apresentam padrão dendrítico, cujo canal principal apresenta vale encaixado, controlado por alinhamentos estruturais, sem deixar 
faixa significativa de planície fluvial. Estes cursos d'águas apresentam foz afogada constituindo Rias Fluviais, e está sujeitos a forte oscilação anual das águas do rio Negro (Figura 50).

Os igarapés possuem extensão variável de alguns metros a quilômetros, com larguras também variáveis de cerca de 100 a 1000 metros e profundidades médias de 5 a 10 metros. Alguns igarapés são mais estreitos e menos profundos. Na área do complexo todos os igarapés são constituídos por águas pretas ricas em matéria orgânica.

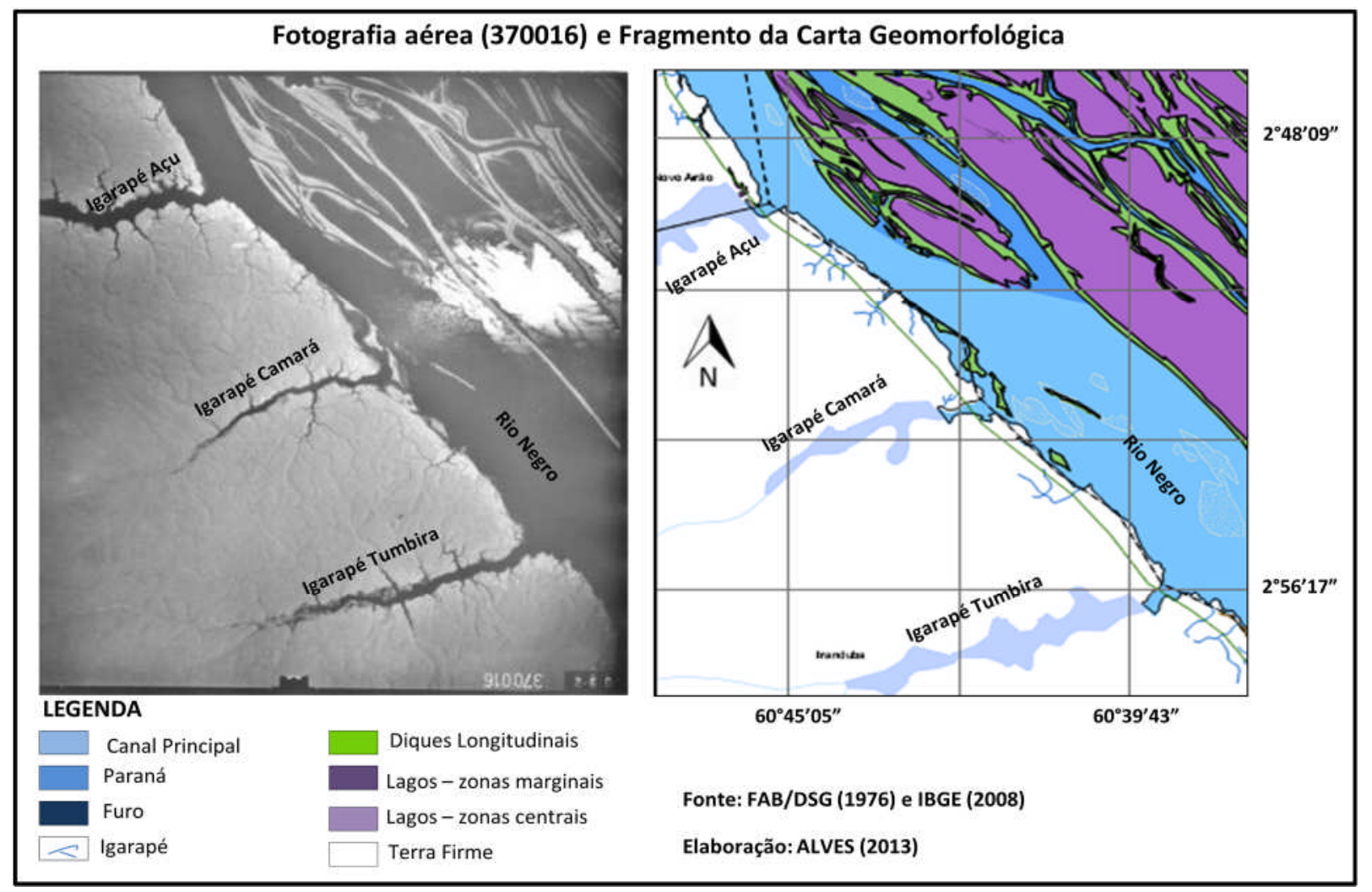

Figura 50: Ria - Padrão Dentrítico: Igarapés

\subsubsection{Barras Fluviais}

As Barras Fluviais foram classificadas e subdivididas neste estudo em Barras Fluviais Centrais e Barras Fluviais Laterais de acordo com o seu local de formação.

As Barras Fluviais Centrais formam-se principalmente na frente dos promontórios das ilhas fluviais, lateralmente aos diques longitudinais e na confluência de dois paranás e somente emergem durante o período de vazante do rio Negro. Estas barras, localmente chamadas de praias (por ex: Praia do Meio, Praia do Baixote), apresentam largura e extensão variadas, com valores acima de 200 metros. Dependendo da cota anual de vazante, estas barras chegam a ter 
mais de $1 \mathrm{~km}$ de extensão. A maioria destas barras é longitudinal ao sentido do fluxo fluvial. Barras transversais também foram mapeadas.

Nas extensas barras fluviais centrais formadas no sentido da corrente e localizadas nos paranás e no rio Negro em Anavilhanas foram identificadas marcas onduladas e megaondulações (dunas) com comprimentos de onda superiores a 13 metros, conforme dados coletados em campo e sumarizados na tabela 2.

Tabela 2 - Elementos das Dunas

\begin{tabular}{|c|c|c|c|c|}
\hline Local & $\begin{array}{l}\text { Coordenadas } \\
\text { geográficas }\end{array}$ & $\begin{array}{c}\text { Comprimento } \\
\text { de onda }(\chi)\end{array}$ & $\begin{array}{c}\text { Altura ou } \\
\text { amplitude da } \\
\text { onda }(\mathbf{H})\end{array}$ & Declividade \\
\hline Praia do Meio & $\begin{array}{l}\text { Lat. } 02^{\circ} .35^{\prime \prime} 44.7^{\prime \prime} \mathrm{S} \\
\text { Long. } 60^{\circ} .56^{\prime \prime} 39.7 ” \mathrm{~W}\end{array}$ & $19,00 \mathrm{~m}$ & $0,34 \mathrm{~m}$ & $01^{\circ}$ a $03^{\circ}$ \\
\hline Praia do Arara & $\begin{array}{l}\text { Lat. } 02^{\circ} 32 " 46.6 " \mathrm{~S} \\
\text { Long. } 06^{\circ} 59 " 51.8 ” \mathrm{~W}\end{array}$ & $17,40 \mathrm{~cm}$ & $0,35 \mathrm{~m}$ & $01^{\circ}$ \\
\hline $\begin{array}{c}\text { Praia do Baixote } \\
\text { (Paraná do } \\
\text { Cachimbo) }\end{array}$ & $\begin{array}{l}\text { Lat. } 02^{\circ} 26^{\prime \prime} 03.3 " \mathrm{~S} \\
\text { Long. } 61^{\circ} 03 " 39.6 ” \mathrm{~W}\end{array}$ & $\begin{array}{l}13,90 \mathrm{~m} \\
17,30 \mathrm{~m} \\
18,00 \mathrm{~m} \\
18,00 \mathrm{~m} \\
18,30 \mathrm{~m}\end{array}$ & $0,77 \mathrm{~m}$ & $\begin{array}{l}24^{\circ} \\
24^{\circ} \\
21^{\circ} \\
21^{\circ} \\
28^{\circ}\end{array}$ \\
\hline Praia do Baixote & $\begin{array}{l}\text { Lat. } 02^{\circ} 24^{\prime \prime} 00.3 " \mathrm{~S} \\
\text { Long. } 61^{\circ} 04^{\prime \prime} 17.4 " \mathrm{~W}\end{array}$ & $\begin{array}{l}48,80 \mathrm{~m} \\
43,50 \mathrm{~m} \\
39,30 \mathrm{~m}\end{array}$ & $0,77 \mathrm{~m}$ & $\begin{array}{l}19^{\circ} \\
25^{\circ} \\
20^{\circ}\end{array}$ \\
\hline
\end{tabular}

Na confluência dos rios e igarapés da Terra Firme com o rio Negro formam-se as Barras Fluviais Laterais cujo suprimento de material é fornecido pelos igarapés e/ou rios. Estas barras fluviais foram identificadas na confluência de todos os rios e igarapés mapeados tanto na área montante e central do complexo de Anavilhanas, como na porção sul do arquipélago, nas proximidades de Manaus. Estas são mais estreitas que as barras fluviais centrais, com cerca de 100 a 200 metros de largura, e possuem extensão de até 500 metros (Figuras 51 e 52). 


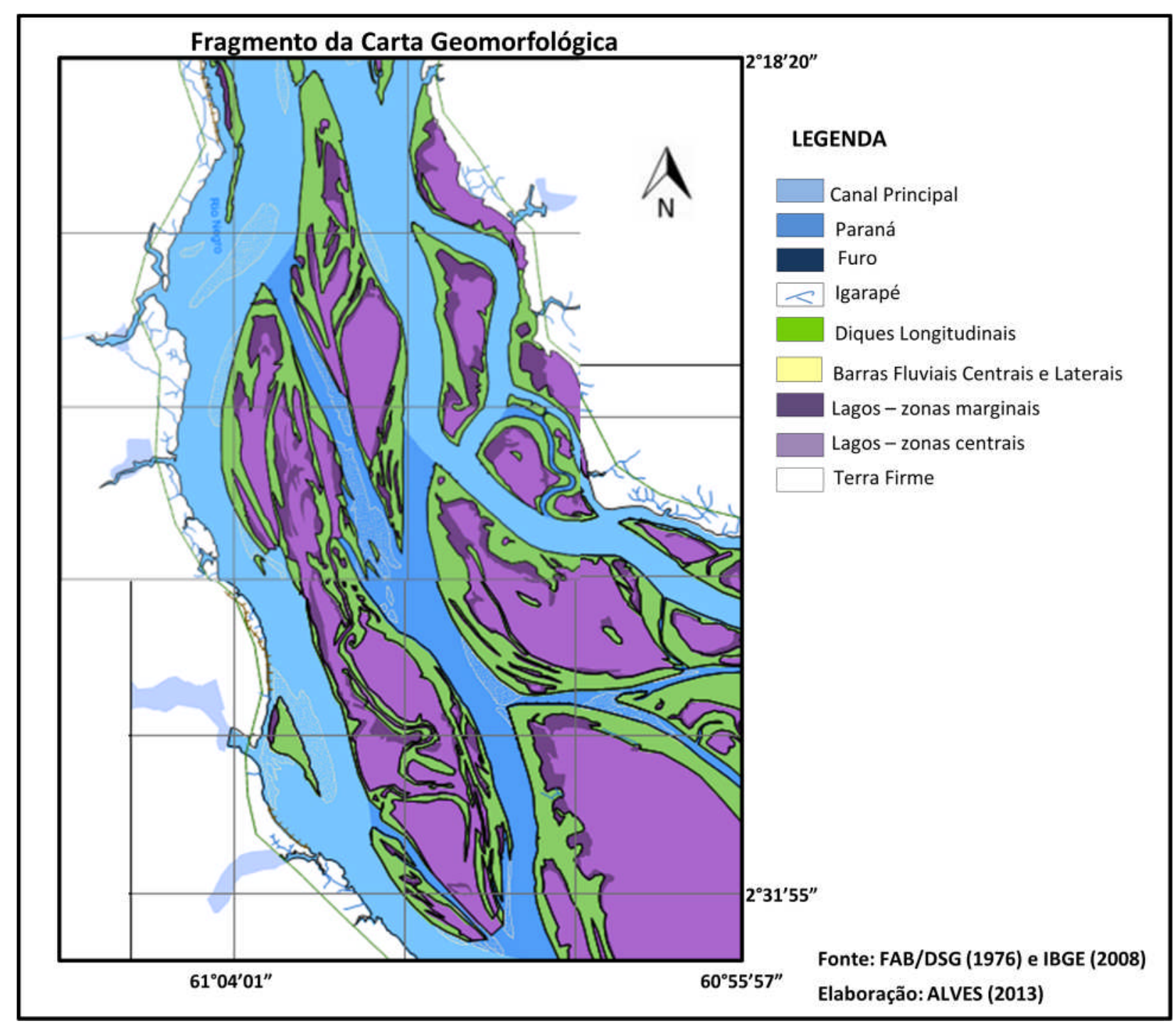

Figura 51: Barras Fluviais Centrais e Laterais na área do Complexo de Anavilhanas. 

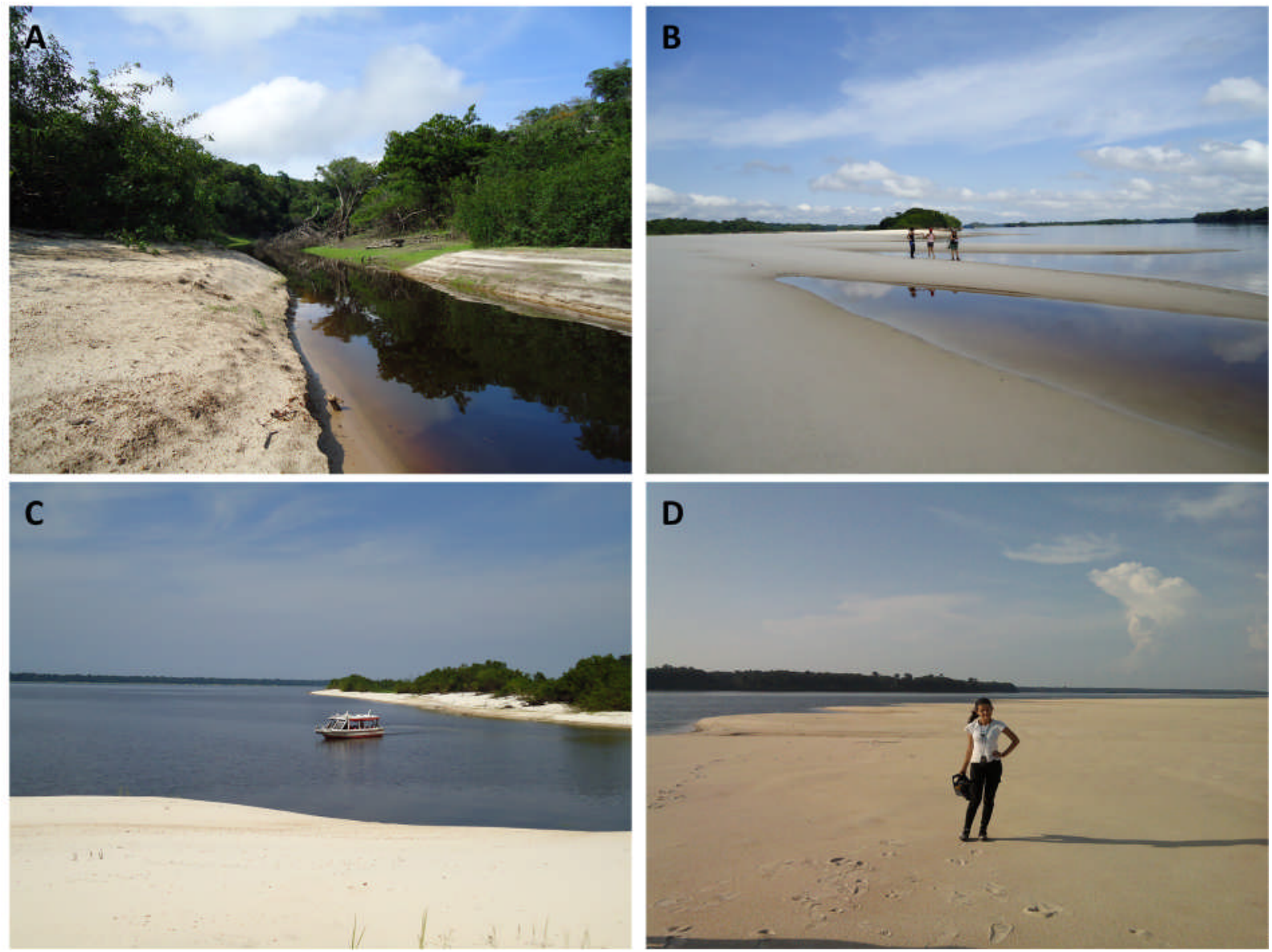

Figura 52: Exemplos de morfologias de barras fluviais: A: Barra fluvial lateral localizada na confluência do igarapé com o rio Negro; B: Barras fluviais centrais; C: Barra fluvial lateral jusante do arquipélago; D: Barra fluvial central - Praia do Meio (imagens da autora).

\subsubsection{Margens}

$\mathrm{Na}$ área do Complexo de Anavilhanas distinguem-se dois tipos de margens: as Falésias relativas às margens do canal principal, rio Negro e de alguns igarapés (por ex: Igarapé do Sobrado), e as margens dos paranás nas ilhas fluviais onde ocorrem os fenômenos de "Terras Caídas".

As Falésias Fluviais são mapeadas tanto na margem esquerda como na margem direita do rio Negro. Predominam sedimentos da Formação Alter do Chão (arenitos e siltitos), e atingem cerca de 12 metros de altura na área do Arquipélago, com declividades superiores a $45^{\circ}$. Estas falésias apresentam amplitudes maiores nas proximidades da cidade de Manaus. 
As margens dos paranás, mais sujeitas à ocorrência do fenômeno de "terras caídas", apresentam altura variável de 3 a 11 metros e apresentam elevada declividade variável de $14^{\circ}$ a $40^{\circ}$.

\subsubsection{Planície de Inundação}

O projeto RADAM (1978) classifica as ilhas do Complexo de Anavilhanas como planície fluvial, caracterizadas como áreas aplainadas resultante da acumulação fluvial periódica ou permanentemente alagada, apresentado, geralmente diques marginais, canais anastomosados e lagos. Esta mesma classificação é adotada nesta pesquisa, ou seja, as ilhas do Complexo de Anavilhanas correspondem à planície de inundação do rio Negro na área do complexo, estas caracterizadas pela presença de vegetação, mata de igapó, sazonalmente inundadas durante as cheias anuais, com amplitudes médias de 11 metros entre a cheia e vazante. Os elementos descritos a seguir fazem parte deste sistema.

\subsubsection{Ilhas}

\section{a) Promontórios}

As ilhas do complexo de Anavilhanas apresentam formas únicas caracterizadas pela presença de promontórios em sua área frontal, na direção oposta ao sentido da corrente fluvial. Estes promontórios apresentam em média 10 a 8 metros de altura, alguns alcançando valores superiores a 12 metros, em relação à cota de vazante. A declividade destes promontórios é bastante acentuada em torno de $20^{\circ}$ a $40^{\circ}$, atingindo valores de $14^{\circ}$ nos promontórios das ilhas localizadas na área jusante do arquipélago. Em campo observa-se uma redução na altura dos promomtórios das ilhas de montante para jusante no arquipélago.

Outra feição morfológica marcante dos promontórios é a presença de um pequeno lago isolado, de morfologia ocelar ou em forma de meia-lua, na sua região central (Figura 53). 


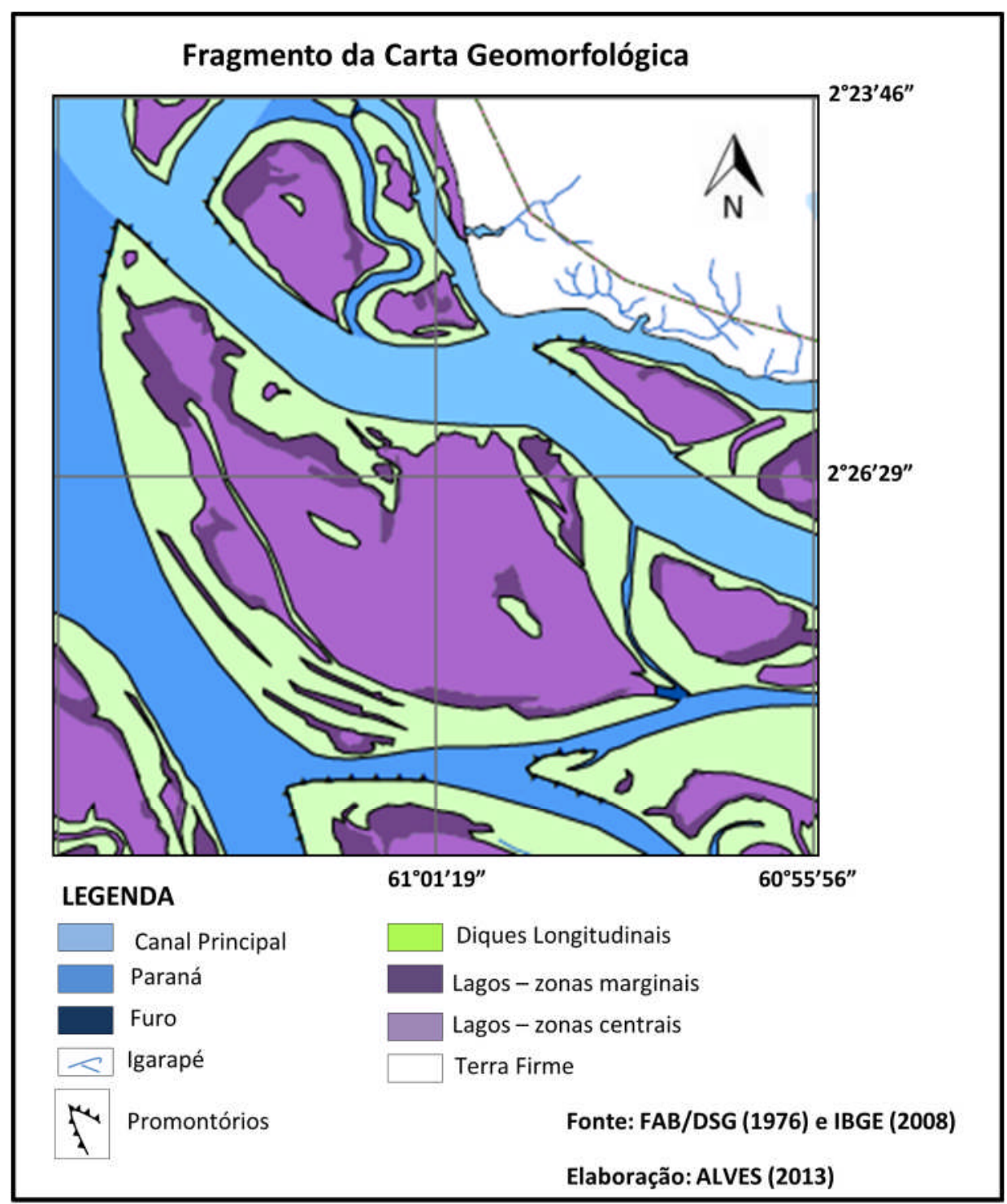

Figura 53: Promontórios das ilhas do Complexo de Anavilhanas

\section{b) Diques Longitudinais}

Os diques longitudinais que formam as ilhas do complexo de Anavilhanas apresentam altura variável sendo mais elevados nas proximidades dos promontórios, com amplitude média de 11 metros adotando-se como referência as cotas de vazante, e mais baixos na parte final das ilhas onde atigem cerca de 2 metros de altura, evidenciando uma redução na altura destes de montante para jusante em cada ilha. De uma maneira geral observa-se o mesmo comportamento destes diques no conjunto total do complexo, ou seja, as ilhas de montante apresentam diques com altura maior que as ilhas de jusante do complexo. Estes diques apresentam elevação máxima nas proximidades do canal principal e dos paranás, em cuja direção forma margens altas e 
íngremes com declividades variáveis na faixa de $35^{\circ}$ a $40^{\circ}$, enquanto em direção aos lagos a declividade está na faixa de $8^{\circ}$ a $10^{\circ}$.

Nas ilhas localizadas nas proximidades da confluência com o rio Solimões os diques longitudinais são mais estreitos e alogados, de formas retilíneas e possuem altura (1,5 a 3,0 metros) e declividade de $14^{\circ}$, valores bastante inferiores aos registrados para as ilhas localizadas a montante.

Os diques longitudinais maiores possuem cerca de $16 \mathrm{~km}$ de extensão e de 1 a $2 \mathrm{~km}$ de largura. Nas ilhas menores estes chegam a ter apenas $2 \mathrm{~km}$ de extensão e largura de 200 a 100 metros. Estes diques isolam do canal principal e paranás, inúmeros lagos de dimensões variadas conectados aos paranás e canal principal por meio de furos (Figura 54).

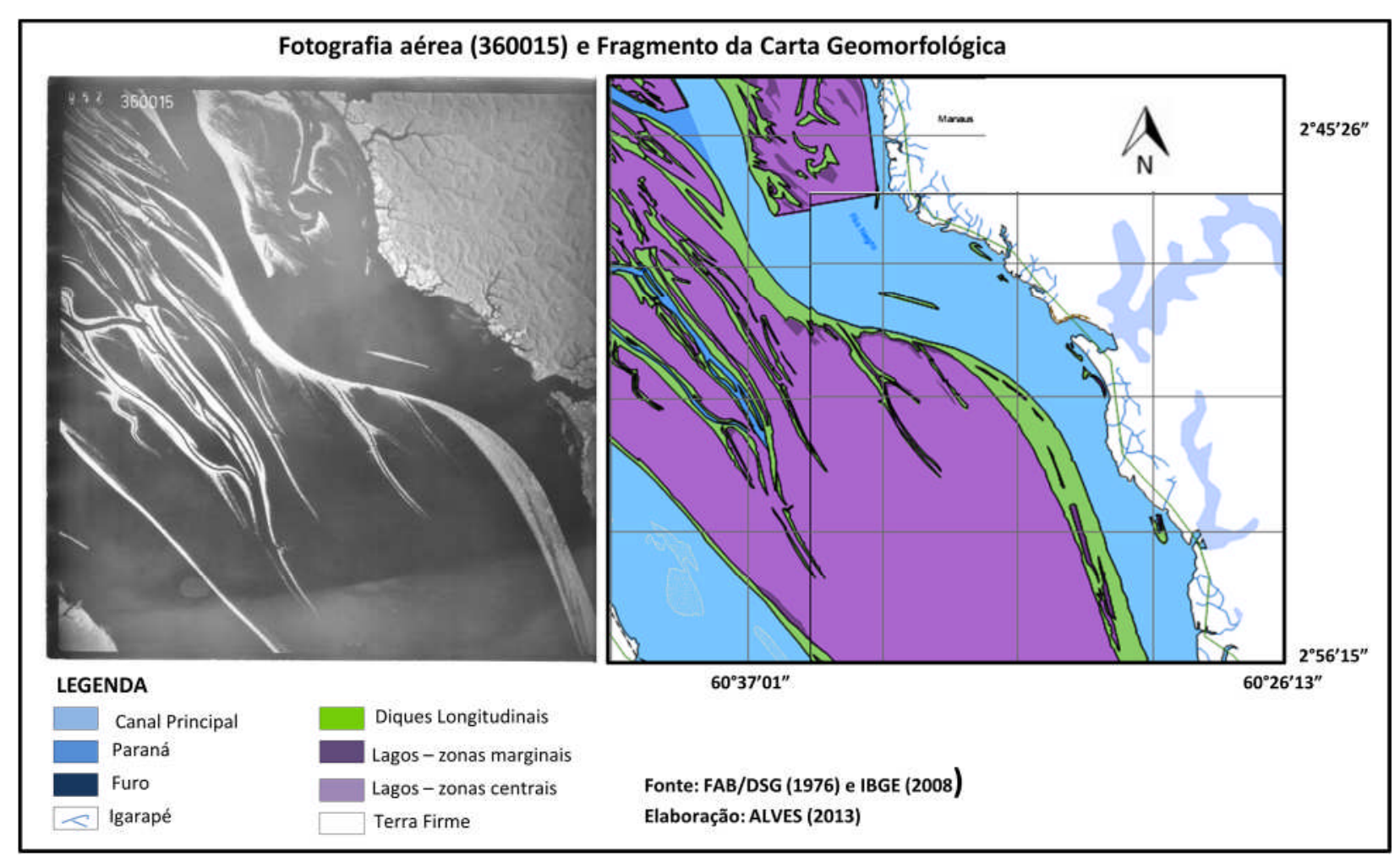

Figura 54: Ilhas: Diques Longitudinais 


\section{c) Lagos}

No Complexo de Anavilhanas os lagos possuem formas alongadas, alguns são arredondados, ocelares ou em forma de meia-lua, e tamanhos variados, predominando lagos redondos e extensos que se localizam na parte central das ilhas fluviais. Lagos menores e isolados, de morfologia ocelar, ocorre nos promontórios das ilhas, enquanto grandes lagos abertos com conexão direta com o canal principal, estão localizados na porção sul do complexo.

Os lagos marginais, isolados ou sazonalmente conectados às águas de transbordamento, predominam no interior das ilhas e apresentam áreas bastantes expressivas restringindo a superfície das ilhas. Estes possuem profundidades que variam entre 1 a 20 m e estão conectados ao canal principal e paranás por furos.

Zonas centrais e marginais foram diferenciadas durante a fase de mapeamento preliminar. As zonas centrais correspondem a áreas permanentemente inundadas tendo como limite a lâmina de água durante a vazante. As zonas marginais correspondem à faixa onde transita o limite lacustre durante a cheia anual, e são marcadas pela presença de Florestas inundadas de Macacarecuias (Escheweleira tenuifolia) e por espécies pioneiras de curto ciclo de vida.

Piedade, Junk e Parolin (2005) ao pesquisarem a vegetação arbórea de Anavilhanas e a distribuição das espécies vegetais ao longo da topossequência insular, em relação ao número de dias de alagação, de dois sítios (Lago do Prato e Lado Miuá) localizados na região sul do complexo, fornecem dados morfométricos referentes às zonas marginais destes lagos, apresentados na tabela 3, tendo como cota de referência a cota de vazante de 17 metros e a cota de cheia de 28,2 metros. Esta faixa corresponderia às áreas nas quais os dias de inundação, no ano hidrológico de sua série estudada, variaram entre aproximadamente 360 dias (proximamente ao limite lacustre) e aproximadamente 180 dias (proximamente ao limite dos diques, exetuandoos).

Tabela 3 - Dados morfométricos das zonas marginais dos lagos do Prato e Miuá (PIEDADE; JUNK; PAROLIN, 2005)

\begin{tabular}{llcccc}
\hline Sítio & & $\begin{array}{c}\mathbf{N}^{\mathbf{0}} \text { de dias } \\
\text { de alagação }\end{array}$ & $\begin{array}{c}\text { Largura } \\
(\mathbf{m})\end{array}$ & $\begin{array}{c}\text { Amplitude } \\
\text { topográfica } \\
(\mathbf{m})\end{array}$ & $\begin{array}{c}\text { Declividade } \\
(\mathbf{(})\end{array}$ \\
\hline Lago do Prato & Zona Marginal & $180-360$ & 80 & 8 & 5,7 \\
Lago Miuá & Zona marginal & $180-360$ & 90 & 8 & 5,1 \\
\hline
\end{tabular}




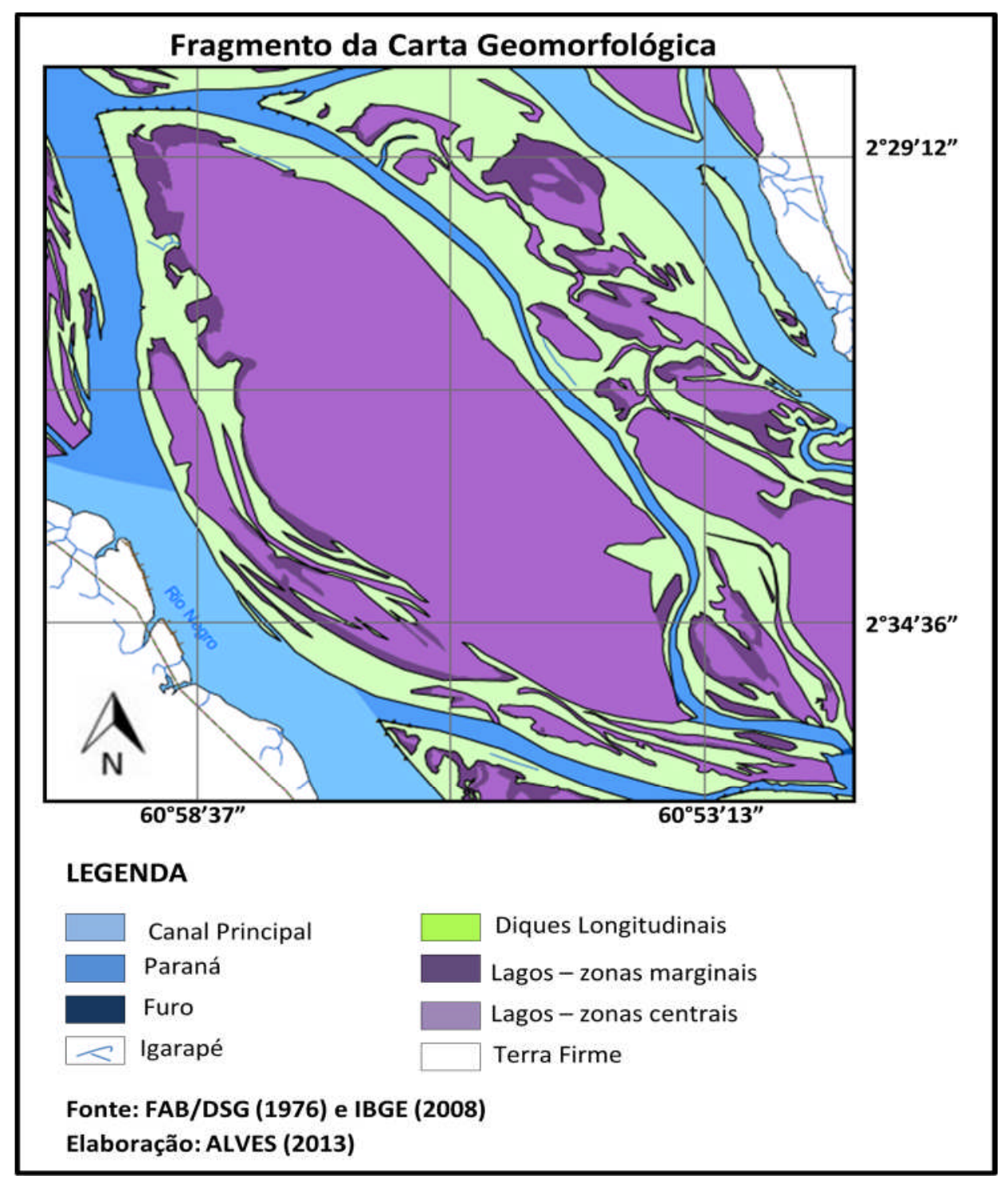

Figura 55: Lagos - Zonas Marginais e Centrais

\subsubsection{Sistema de Terra Firme}

O Sistema de Terra Firme compreende as formas de relevo modeladas nos depósitos da Formação Alter do Chão na área do Planalto do Uatumã-Jari (IBGE, 2010). Estes depósitos formam as falésias fluviais na margem do rio Negro e igarapés na área do complexo de Anavilhanas. O relevo é plano-ondulado a tabular com altitudes em torno de 150 metros, com interflúvios tabulares de dimensões variáveis de 250 a 750 metros, de topos aplainados, separados geralmente por vales de fundo plano e eventualmente em "V", cuja rede de drenagem 
apresenta padrão dendrítico e intensidade de aprofundamento de drenagem fraca (tipo 2), segundo o RADAMBRASIL (1978).

\subsection{CARACTERIZAÇÃO SEDIMENTOLÓGICA}

Neste item são apresentados os resultados obtidos nas análises granulométricas e texturais das amostras coletadas em campo, nas observações dos perfis e nas diversas unidades morfológicas mapeadas. No total foram realizados 04 (quatro) perfis, 01 (uma) tradagem e 25 coletas em pontos amostrais das morfologias acima descritas totalizando 54 amostras, sendo 01 (uma) amostra de rocha (arenito) da Formação Alter do Chão.

\subsubsection{Análise Textural dos Perfis}

Conforme já citado acima foram descritos um total de 04 (quatro) perfis em campo, todos eles localizados nas ilhas do Complexo de Anavilhanas, e nestes, foram realizadas coletas sistemáticas de amostras para análise textural dos sedimentos.

\section{PERFIL 1:}

O Perfil 1 foi executado em uma ilha (Dique longitudinal) localizada na parte proximal do Complexo de Anavilhanas, localizado a $02^{\circ} 32^{\prime} 39,3$ ” de latitude S e 6100’22,7'de longitude $\mathrm{W}$ (Figura 56). A profundidade do perfil executado foi de 1,70 m, cujo material apresenta-se bem compactado (microporosidade) e com uma grande quantidade de raízes de vegetais nos níveis mais superficiais e cor cinza predominante. O material amostrado foi coletado a cada 0,30 m ou quando ocorreu variação da textura descrita em campo. No total foram coletadas 07 (sete) amostras para análise das frações granulométricas (Tabela 4). 
Tabela 4 - Composição Granulométrica do Perfil 1 (baseada em Wentworth, 1922):

\begin{tabular}{|c|c|c|c|c|c|c|c|c|c|c|}
\hline \multirow[t]{2}{*}{ Amostra } & \multirow[t]{2}{*}{$\begin{array}{c}\text { Profundidade } \\
\text { do intervalo } \\
\text { de coleta }\end{array}$} & \multicolumn{3}{|c|}{$\begin{array}{c}\text { Composição } \\
\text { Granulométrica } \\
(\%)\end{array}$} & \multicolumn{6}{|c|}{$\begin{array}{c}\text { Distribuição da Fração Areia } \\
(\%)\end{array}$} \\
\hline & & $\begin{array}{c}\text { areia } \\
\text { total }\end{array}$ & silte & argila & grânulos & $\begin{array}{c}\text { areia } \\
\text { muito } \\
\text { grossa }\end{array}$ & $\begin{array}{c}\text { areia } \\
\text { grossa }\end{array}$ & $\begin{array}{l}\text { areia } \\
\text { média }\end{array}$ & $\begin{array}{c}\text { areia } \\
\text { fina }\end{array}$ & $\begin{array}{c}\text { areia } \\
\text { muito } \\
\text { fina }\end{array}$ \\
\hline ANA_26g & $0,0-0,30$ & 84,55 & 12,45 & 3,00 & 0,00 & 0,00 & 0,45 & 0,35 & 8,7 & 75,05 \\
\hline ANA_26f & $0,30-0,60$ & 84,55 & 12.45 & 3,00 & 0,00 & 0,00 & 0,00 & 0,00 & 11,45 & 73,10 \\
\hline ANA_26e & $0,60-1,00$ & 30,80 & 48,70 & 20,50 & 0,00 & 0,10 & 0,10 & 0,20 & 1,00 & 29,40 \\
\hline ANA_26d & $1,00-1,30$ & 59,7 & 32,30 & 8,00 & 0,00 & 0,00 & 0,00 & 0,05 & 1,60 & 58,05 \\
\hline ANA_26c & $1,30-1,50$ & 73,65 & 25,85 & 0,50 & 0,00 & 0,00 & 0,00 & 0,05 & 3,65 & 69,95 \\
\hline ANA_26b & $1,50-1,60$ & 83,05 & 16,45 & 0,50 & 0,00 & 0,00 & 0,00 & 0,15 & 6,85 & 76,05 \\
\hline ANA_26a & $1,60-1,70$ & 73,75 & 20,75 & 5,5 & 0,00 & 0,00 & 0,00 & 0,00 & 5,3 & 68,45 \\
\hline
\end{tabular}

Os sedimentos variam, de acordo com o Diagrama de Flemming (2000), do tipo Areia Levemente Lamosa, classe A-I (areia levemente siltosa), a Lama Arenosa, classe C-III (lama arenosa siltosa) e Areia Lamosa, classe B-I (areia muito siltosa) (Quadro 13).

Quadro 13: Classe textural e Tipo de sedimentos para o Perfil 1 de acordo com a classificação de Flemming (2000)

\begin{tabular}{|l|c|l|l|}
\hline Amostra & Código & \multicolumn{1}{|c|}{ Classe Textural } & \multicolumn{1}{c|}{ Tipo de Sedimento } \\
\hline ANA_26g & A-I & areia levemente siltosa & Areia Levemente Lamosa \\
\hline ANA_26f & A-I & areia levemente siltosa & Areia Levemente Lamosa \\
\hline ANA_26e & C-III & lama arenosa siltosa & Lama Arenosa \\
\hline ANA_26d & B-I & areia muito siltosa & Areia Lamosa \\
\hline ANA_26c & A-I & areia levemente siltosa & Areia Levemente Lamosa \\
\hline ANA_26b & A-I & areia levemente siltosa & Areia Levemente Lamosa \\
\hline ANA_26a & A-I & areia levemente siltosa & Areia Levemente Lamosa \\
\hline
\end{tabular}

O principal fator que chama a atenção para os dados acima levantados é exatamente a predominância da fração areia (areia muito fina) nesta ilha. Nesse caso específico também foram coletadas amostras em pontos de controle em que se observou em campo que abaixo destas areias encontra-se um pacote de material síltico-argiloso. Um dos pontos de controle utilizado para checar a continuidade lateral deste material arenoso foi o ponto de número 20, com

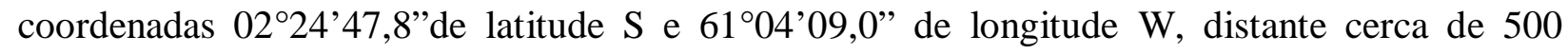
metros a jusante do perfil 1. Ali realizou-se coleta de amostra com o uso de trado do tipo holandês até a profundidade de 1,00 m. A fração predominante foi areia, com quantidades 
subordinadas de silte e argila (Tabela 5). A classe textural encontrada foi A-I (areia levemente siltosa), caracterizando sedimentos do tipo Areia Levemente Lamosa (Quadro 14). A ocorrência desse tipo de material também foi identificada noutros locais, a exemplo do Paraná da Lua. O mapeamento de campo da ocorrência deste material aliado às análises do material coletado em perfil e tradagem e às observações da dinâmica fluvial da área, indicaram que este material está sendo transportado em suspensão pelo rio Negro no período de cheias e, em grande parte, depositado sobre os sedimentos síltico-argilosos das ilhas durante a descida das águas.

Tabela 5 - Composição Granulométrica da Tradagem (baseada em Wentworth, 1922):

\begin{tabular}{|c|c|c|c|c|c|c|c|c|c|c|}
\hline \multirow[t]{2}{*}{ Amostra } & \multirow{2}{*}{$\begin{array}{c}\text { Profundidade } \\
\text { do intervalo } \\
\text { de coleta } \\
\end{array}$} & \multicolumn{3}{|c|}{$\begin{array}{c}\text { Composição } \\
\text { Granulométrica }(\%)\end{array}$} & \multicolumn{6}{|c|}{$\begin{array}{c}\text { Distribuição da Fração Areia } \\
(\%)\end{array}$} \\
\hline & & $\begin{array}{c}\text { areia } \\
\text { total }\end{array}$ & silte & argila & grânulos & $\begin{array}{c}\text { areia } \\
\text { muito } \\
\text { grossa }\end{array}$ & $\begin{array}{c}\text { areia } \\
\text { grossa }\end{array}$ & $\begin{array}{l}\text { areia } \\
\text { média }\end{array}$ & $\begin{array}{c}\text { areia } \\
\text { fina }\end{array}$ & $\begin{array}{c}\text { areia } \\
\text { muito } \\
\text { fina }\end{array}$ \\
\hline ANA_27a & $0,00-0,20$ & 92,05 & 7,95 & 0,00 & 0,00 & 0,00 & 0,00 & 0,50 & 15,50 & 76,05 \\
\hline ANA_27b & $0,20-0,60$ & 82,05 & 14,95 & 3,00 & 0,00 & 0,00 & 0,00 & 0,00 & 8,45 & 73,60 \\
\hline ANA_27c & $0,60-1,00$ & 81,85 & 17,65 & 0,50 & 0,00 & 0,00 & 0,00 & 0,00 & 18,00 & 63,85 \\
\hline
\end{tabular}

Quadro 14: Classe textural e Tipo de sedimentos para a Tradagem de acordo com a classificação de Flemming (2000)

\begin{tabular}{|l|c|l|l|}
\hline Amostra & Código & \multicolumn{1}{|c|}{ Classe Textural } & \multicolumn{1}{c|}{ Tipo de Sedimento } \\
\hline ANA_27a & A-I & areia levemente siltosa & Areia Levemente Lamosa \\
\hline ANA_27b & A-I & areia levemente siltosa & Areia Levemente Lamosa \\
\hline ANA_27c & A-I & areia levemente siltosa & Areia Levemente Lamosa \\
\hline
\end{tabular}

Buscando fazer perfis de controle do tipo de material presente nos diques longitudinais foram realizados 03 (três) perfis na grande Ilha das Anavilhanas, um na parte distal desta ilha (Perfil 2), outro em sua porção central (Perfil 3) e um outro na sua região de promontório (Perfil 4). Esta ilha, como todas as outras observadas em Anavilhanas, possui relevo mais alto nos promontórios e relevo mais suave em sua parte final, no sentido da corrente fluvial. Este fato também indica que pode ocorrer uma maior acumulação de sedimentos de montante para jusante no complexo como um todo. 


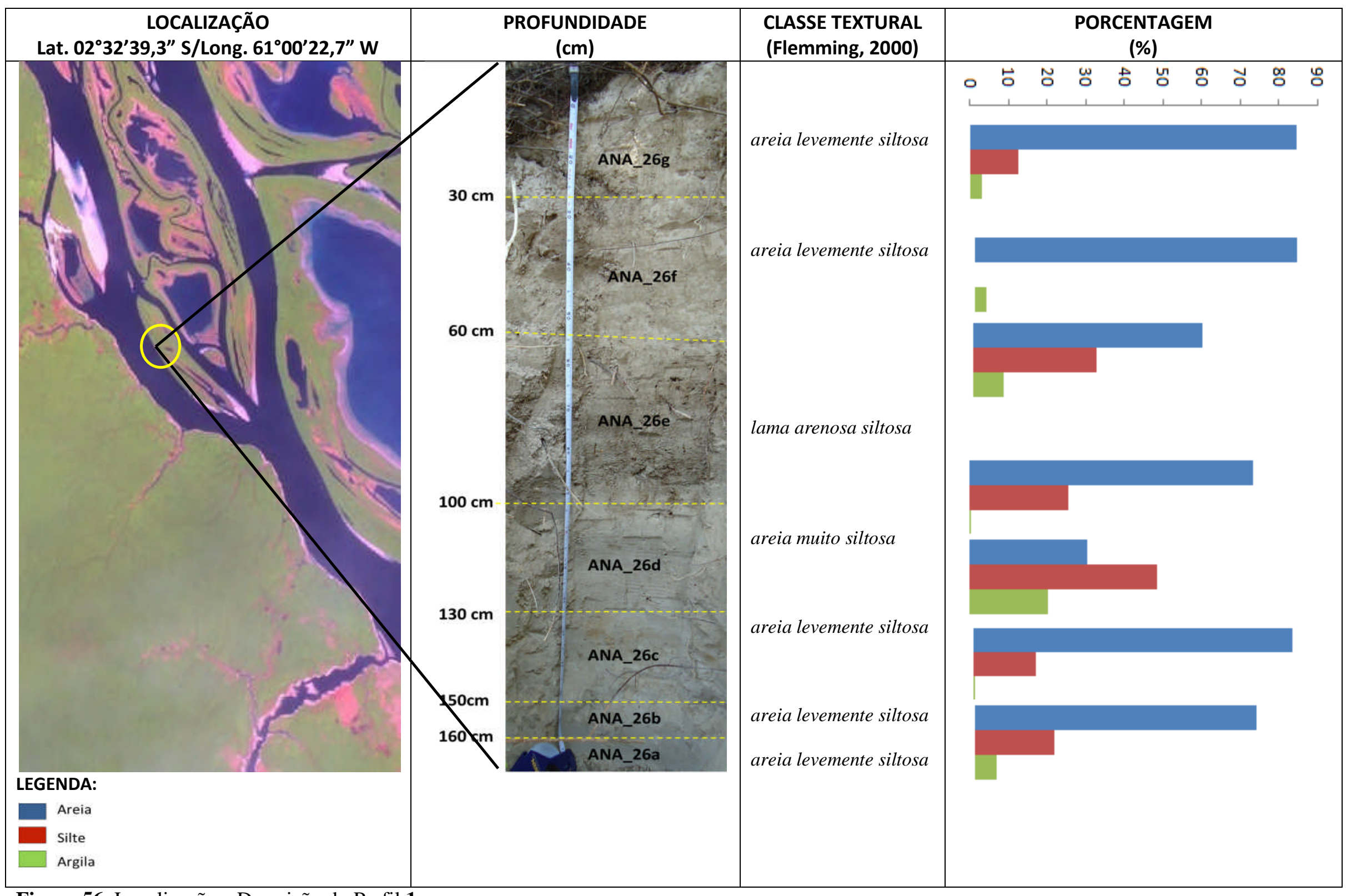

Figura 56: Localização e Descrição do Perfil 1 


\section{PERFIL 2:}

O Perfil 2 foi executado na extremidade sul da Ilha das Anavilhanas que está localizada em frente a cidade de Novo Airão, nas coordenadas 0241'33,2" de latitude S e 6049'51,4"de longitude W (Figura 57). O perfil executado possui 2,20 $\mathrm{m}$ de profundidade, apresenta estrutura compactada com microporosidade, em parte bioturbada devido à grande quantidade de raízes, e cor cinza-amarelado. O material amostrado foi coletado a intervalos de $0,20 \mathrm{~m}$ ou, então, quando ocorreu variação da textura descrita em campo. No total foram coletadas 06 (seis) amostras para análise granulométrica (Tabela 6).

Tabela 6 - Composição Granulométrica do Perfil 2 (baseada em Wentworth, 1922):

\begin{tabular}{|c|c|c|c|c|c|c|c|c|c|c|}
\hline \multirow[t]{2}{*}{ Amostra } & \multirow[t]{2}{*}{$\begin{array}{c}\text { Profundidade } \\
\text { do intervalo } \\
\text { de coleta } \\
\end{array}$} & \multicolumn{3}{|c|}{$\begin{array}{c}\text { Composição } \\
\text { Granulométrica } \\
(\%)\end{array}$} & \multicolumn{6}{|c|}{$\begin{array}{c}\text { Distribuição da Fração Areia } \\
(\%)\end{array}$} \\
\hline & & $\begin{array}{c}\text { areia } \\
\text { total }\end{array}$ & silte & argila & grânulos & $\begin{array}{l}\text { areia } \\
\text { muito } \\
\text { grossa }\end{array}$ & $\begin{array}{c}\text { areia } \\
\text { grossa }\end{array}$ & $\begin{array}{l}\text { areia } \\
\text { media }\end{array}$ & $\begin{array}{c}\text { areia } \\
\text { fina }\end{array}$ & $\begin{array}{c}\text { areia } \\
\text { muito } \\
\text { fina }\end{array}$ \\
\hline ANA_29f & $0,05-0,45$ & 28,30 & 48,70 & 23,00 & 0,00 & 0,00 & 0,20 & 0,20 & 1,60 & 26,30 \\
\hline ANA_29e & $0,45-1,10$ & 14,60 & 52,50 & 33,00 & 0,00 & 0,00 & 0,00 & 0,00 & 0,40 & 14,20 \\
\hline ANA_29d & $1,10-1,60$ & 14,45 & 52,55 & 33,00 & 0,00 & 0,00 & 0,00 & 0,20 & 0,50 & 13,75 \\
\hline ANA-29c & $1,60-1,80$ & 21,25 & 53,25 & 25,50 & 0,00 & 0,00 & 0,00 & 0,00 & 0,70 & 20,55 \\
\hline ANA_29b & $1,80-2,00$ & 15,25 & 84,25 & 0,50 & 0,00 & 0,00 & 0,00 & 0,00 & 0,35 & 14,90 \\
\hline ANA_29a & $2,00-2,20$ & 19,00 & 55,50 & 25,50 & 0,00 & 0,00 & 0,00 & 0,00 & 0,25 & 18,75 \\
\hline
\end{tabular}

Os sedimentos do Perfil 2 variam, de acordo com o Diagrama de Flemming (2000), do tipo Lama Arenosa, classe C-III (lama arenosa siltosa) e Lama Levemente Arenosa, classes D-I e D-III (lama levemente arenosa extremamente siltosa e lama levemente arenosa siltosa, respectivamente) (Quadro 15).

Quadro 15: Classe textural e Tipo de sedimentos para o Perfil 2 de acordo com a classificação de Flemming (2000)

\begin{tabular}{|l|c|l|l|}
\hline Amostra & Código & \multicolumn{1}{|c|}{ Classe Textural } & \multicolumn{1}{|c|}{ Tipo de Sedimento } \\
\hline ANA_29f & C-III & lama arenosa siltosa & Lama Arenosa \\
\hline ANA_29e & D-III & lama levemente arenosa siltosa & Lama Levemente Arenosa \\
\hline ANA_29d & D-III & lama levemente arenosa siltosa & Lama Levemente Arenosa \\
\hline ANA_29c & D-III & lama levemente arenosa siltosa & Lama Levemente Arenosa \\
\hline ANA_29b & D-I & $\begin{array}{l}\text { lama levemente arenosa } \\
\text { extremamente siltosa }\end{array}$ & Lama Levemente Arenosa \\
\hline ANA_29a & D-III & lama levemente arenosa siltosa & Lama Levemente Arenosa \\
\hline
\end{tabular}




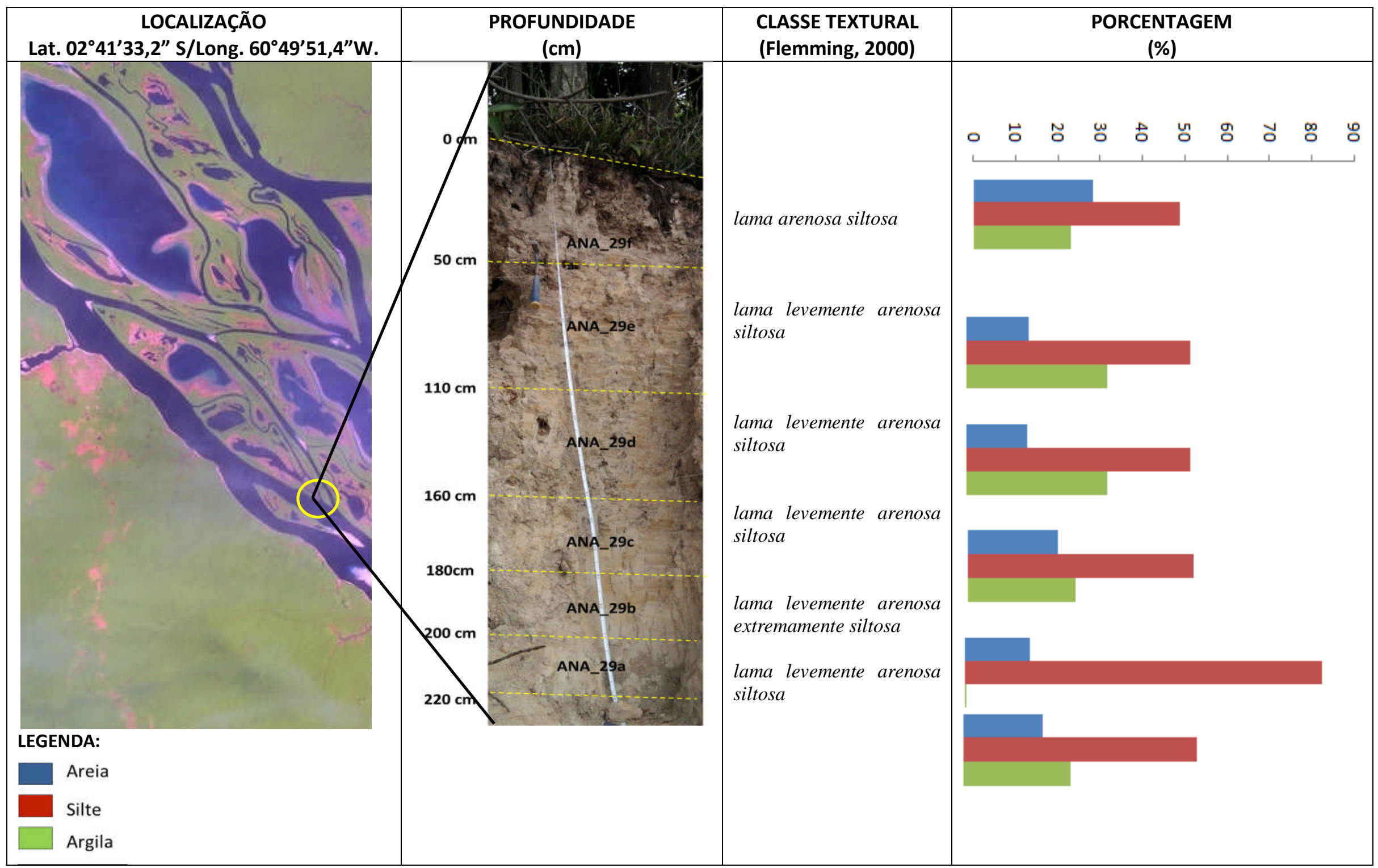

Figura 57: Localização e Descrição do Perfil 2 


\section{PERFIL 3:}

O Perfil 3 foi executado na porção central da Ilha das Anavilhanas localizado no Paraná da Lua, nas coordenadas $02^{\circ} 38^{\prime} 29,5^{\prime}$ ' de latitude S e 6053'00,6”de longitude W (Figura 58). O perfil executado possui 11,00 m de espessura, apresenta estrutura compacta (microporosidade), presença de raízes vegetais no nível mais superficial e cor cinza-amarelado. O material amostrado foi coletado quando ocorreu variação da textura descrita em campo. No total foram coletadas 05 (cinco) amostras para análise granulométrica (Tabela 7).

Tabela 7 - Composição Granulométrica do Perfil 3 (baseada em Wentworth, 1922):

\begin{tabular}{|c|c|c|c|c|c|c|c|c|c|c|}
\hline \multirow[t]{2}{*}{ Amostra } & \multirow[t]{2}{*}{$\begin{array}{c}\text { Profundidade } \\
\text { do intervalo } \\
\text { de coleta } \\
\end{array}$} & \multicolumn{3}{|c|}{$\begin{array}{c}\text { Composição } \\
\text { Granulométrica } \\
(\%)\end{array}$} & \multicolumn{6}{|c|}{$\begin{array}{c}\text { Distribuição da Fração Areia } \\
(\%)\end{array}$} \\
\hline & & $\begin{array}{c}\text { areia } \\
\text { total }\end{array}$ & silte & argila & grânulos & $\begin{array}{c}\text { areia } \\
\text { muito } \\
\text { grossa }\end{array}$ & $\begin{array}{c}\text { areia } \\
\text { grossa }\end{array}$ & $\begin{array}{c}\text { areia } \\
\text { media }\end{array}$ & $\begin{array}{c}\text { areia } \\
\text { fina }\end{array}$ & $\begin{array}{c}\text { areia } \\
\text { muito } \\
\text { fina }\end{array}$ \\
\hline ANA_30e & $0,00-1,90$ & 38,50 & 58,50 & 3,00 & 0,00 & 0,00 & 0,00 & 0,25 & 1,25 & 37,00 \\
\hline ANA_30d & $1,90-3,25$ & 30,05 & 34,45 & 35,50 & 0.00 & 0,00 & 0,00 & 0,00 & 0,60 & 29,45 \\
\hline ANA_30c & $3,25-6,00$ & 19,70 & 39,80 & 40,50 & 0,00 & 0,00 & 0,00 & 0,00 & 0,65 & 19,05 \\
\hline ANA_30b & $6,00-7,00$ & 25,65 & 41,35 & 33,00 & 0,50 & 0,35 & 0,25 & 0,35 & 1,25 & 22,95 \\
\hline ANA_30a & $7,00-?$ & 24,70 & 39,80 & 35,50 & 0,00 & 0,00 & 0,15 & 0,25 & 0,65 & 23,65 \\
\hline
\end{tabular}

Os sedimentos do Perfil 3 variam, de acordo com o Diagrama de Flemming (2000), do tipo Lama Arenosa, classes C-I, C-III e C-IV (lama arenosa extremamente siltosa, lama arenosa siltosa, lama arenosa argilosa, respectivamente) e Lama Levemente Arenosa, classes D-III e DIV (lama levemente arenosa siltosa, lama levemente arenosa argilosa, respectivamente) (Quadro 16).

Quadro 16: Classe textural e Tipo de sedimentos para o Perfil 3 de acordo com a classificação de Flemming (2000)

\begin{tabular}{|l|c|l|l|}
\hline Amostra & Código & \multicolumn{1}{|c|}{ Classe Textural } & \multicolumn{1}{|c|}{ Tipo de Sedimento } \\
\hline ANA_30e & C-I & $\begin{array}{l}\text { lama arenosa extremamente } \\
\text { siltosa }\end{array}$ & Lama Arenosa \\
\hline ANA_30d & C-IV & lama arenosa argilosa & Lama Arenosa \\
\hline ANA_30c & D-IV & lama levemente arenosa argilosa & Lama Levemente Arenosa \\
\hline ANA_30b & C-III & lama arenosa siltosa & Lama Arenosa \\
\hline ANA_30a & D-III & lama levemente arenosa siltosa & Lama Levemente Arenosa \\
\hline
\end{tabular}




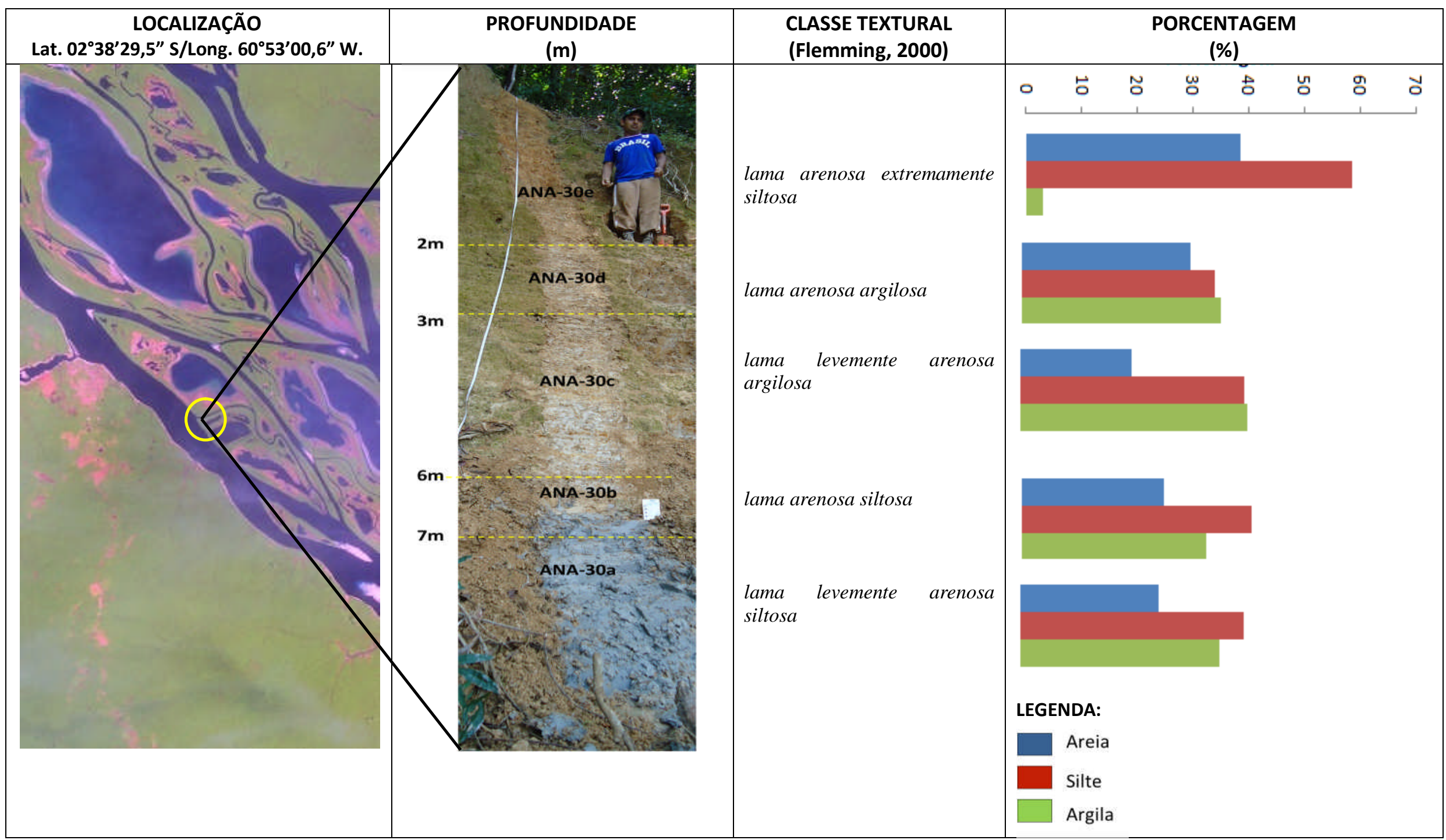

Figura 58: Localização e Descrição do Perfil 3 


\section{PERFIL 4:}

O Perfil 4 foi executado no promontório da Ilha das Anavilhanas localizado nas coordenadas $02^{\circ} 35^{\prime} 44,3^{\prime \prime}$ de latitude S e 6056’38,8'de longitude W (Figura 59). O perfil executado possui 11,00 m de profundidade, estrutura compacta (microporosidade) e com grande quantidade de raízes vegetais nos níveis mais superficiais até a profundidade de 3,50 metros. O material apresenta coloração cinza-amarelada. O material amostrado foi coletado quando ocorreu variação da textura descrita em campo. No total foram coletadas 06 (seis) amostras para análise granulométrica (Tabela 8).

Tabela 8 - Composição Granulométrica do Perfil 4 (baseada em Wentworth, 1922):

\begin{tabular}{|c|c|c|c|c|c|c|c|c|c|c|}
\hline \multirow[t]{2}{*}{ Amostra } & \multirow[t]{2}{*}{$\begin{array}{c}\text { Profundidade } \\
\text { do intervalo } \\
\text { de coleta }\end{array}$} & \multicolumn{3}{|c|}{$\begin{array}{c}\text { Composição } \\
\text { Granulométrica } \\
(\%)\end{array}$} & \multicolumn{6}{|c|}{$\begin{array}{c}\text { Distribuição da Fração Areia } \\
(\%)\end{array}$} \\
\hline & & $\begin{array}{c}\text { areia } \\
\text { total }\end{array}$ & silte & argila & grânulos & $\begin{array}{c}\text { areia } \\
\text { muito } \\
\text { grossa }\end{array}$ & $\begin{array}{c}\text { areia } \\
\text { grossa }\end{array}$ & $\begin{array}{l}\text { areia } \\
\text { media }\end{array}$ & $\begin{array}{c}\text { areia } \\
\text { fina }\end{array}$ & $\begin{array}{c}\text { areia } \\
\text { muito } \\
\text { fina }\end{array}$ \\
\hline ANA_31f & $1,50-2,60$ & 9,95 & 47,05 & 43,00 & 0,00 & 0,00 & 0,00 & 0,05 & 0,25 & 9,65 \\
\hline ANA_31e & $2,60-3,30$ & 12,15 & 44,85 & 43,00 & 0,00 & 0,00 & 0,00 & 0,15 & 0,35 & 11,65 \\
\hline ANA_31d & $3,30-3,70$ & 9,90 & 47,10 & 43,00 & 0,00 & 0,00 & 0,00 & 0,00 & 0,15 & 9,75 \\
\hline ANA_31c & $3,70-5,00$ & 21,35 & 38,15 & 40,50 & 0,00 & 0,00 & 0,00 & 0,45 & 0,50 & 20,40 \\
\hline ANA_31b & $5,00-6,50$ & 8,50 & 46,00 & 45,50 & 0,00 & 0,00 & 0,00 & 0,15 & 0,35 & 8,00 \\
\hline ANA_31a & $6,50-7,00$ & 17,05 & 47,45 & 35,50 & 0,00 & 0,00 & 0,05 & 0,15 & 0,35 & 16,50 \\
\hline
\end{tabular}

Os sedimentos do Perfil 4, de acordo com o Diagrama de Flemming (2000), são do tipo Lama Levemente Arenosa, classes D-III e D-IV (lama levemente arenosa siltosa, lama levemente arenosa argilosa, respectivamente) (Quadro 17).

Quadro 17: Classe textural e Tipo de sedimentos para o Perfil 4 de acordo com a classificação de Flemming (2000)

\begin{tabular}{|l|c|l|l|}
\hline Amostra & Código & \multicolumn{1}{|c|}{ Classe Textural } & \multicolumn{1}{c|}{ Tipo de Sedimento } \\
\hline ANA_31f & D-III & lama levemente arenosa siltosa & Lama Levemente Arenosa \\
\hline ANA_31e & D-III & lama levemente arenosa siltosa & Lama Levemente Arenosa \\
\hline ANA_31d & D-III & lama levemente arenosa siltosa & Lama Levemente Arenosa \\
\hline ANA_31c & D-IV & lama levemente arenosa argilosa & Lama Levemente Arenosa \\
\hline ANA_31b & D-III & lama levemente arenosa siltosa & Lama Levemente Arenosa \\
\hline ANA_31a & D-III & lama levemente arenosa siltosa & Lama Levemente Arenosa \\
\hline
\end{tabular}

Os sedimentos dos perfis 2, 3 e 4 realizados na Ilha Grande das Anavilhanas, são predominantemente do tipo Lama Levemente Arenosa (75-95\% de lama) e Lama Arenosa (50$75 \%$ de lama), diferentemente dos sedimentos do Perfil 1 cujo tipo predominante é Areia Levemente Lamosa (5-25\% de lama) caracterizando os materiais de deposição mais recente. 


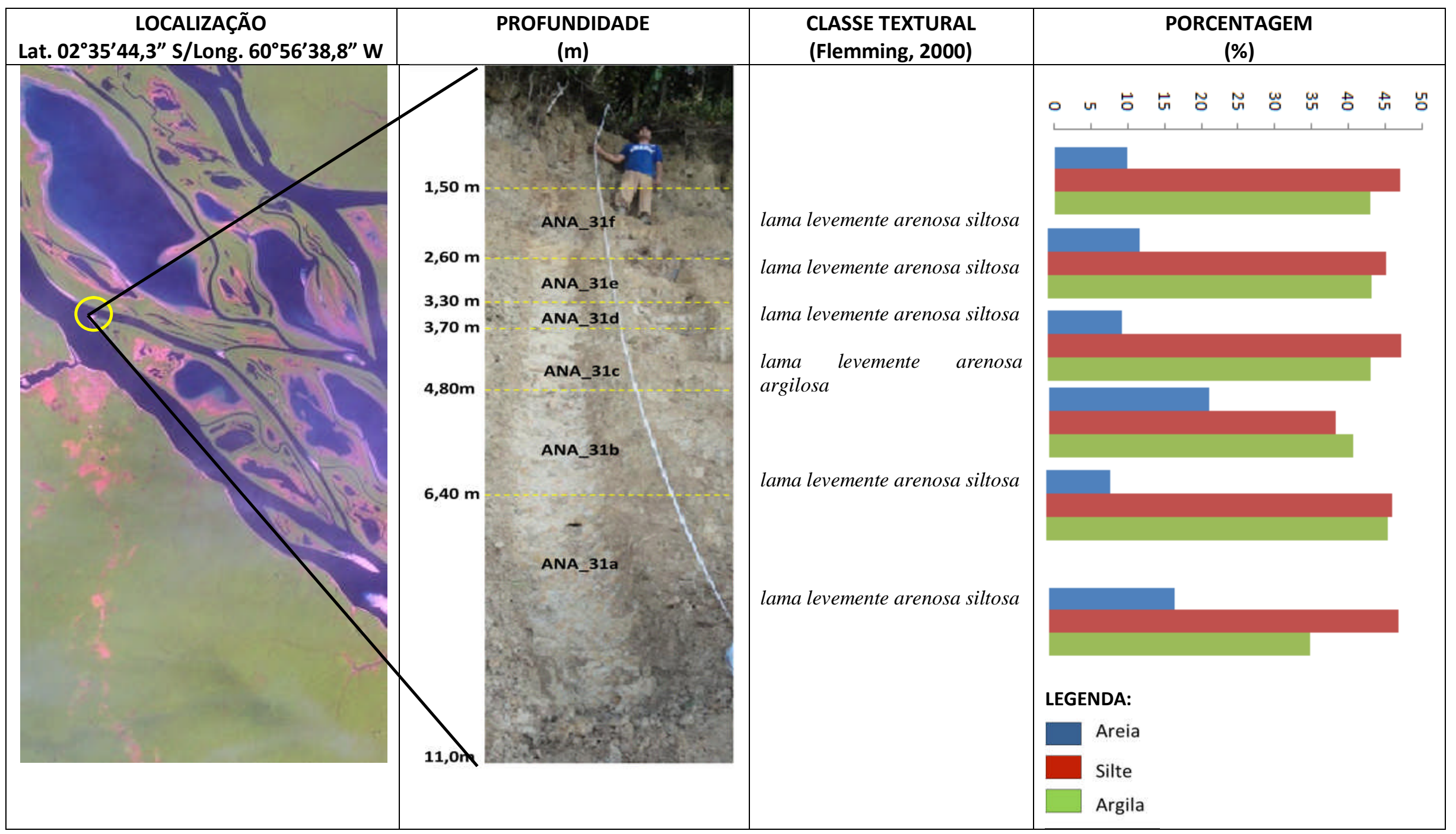

Figura 59: Localização e Descrição do Perfil 4. 


\subsubsection{Análise Textural em Pontos Amostrais das Unidades Morfológicas}

Além dos perfis acima descritos, foram realizadas coletas de amostra de materiais superficiais nas mais diversas unidades morfológicas identificadas no arquipélago incluindo diversas ilhas fluviais, diques longitudinais, lagos, barras fluviais e Terra Firme. Estas descrições juntam-se à anterior, também no sentido de compreender a distribuição espacial dos materiais superficiais e sua relação com as unidades morfológicas e tendências de processos hidromorfodinâmicos.

\subsubsection{Diques Longitudinais}

Os diques longitudinais ${ }^{7}$ das ilhas do arquipélago foram amostrados para reconhecer as tendências espaciais de distribuição do material constituinte e para realizar análises comparativas com os resultados obtidos nos perfis realizados na Grande Ilha das Anavilhanas. No total foram coletadas e analisadas 06 (seis) amostras (Tabela 9), cujas classes texturais e tipo de sedimentos (Quadro 18) constituintes assemelham-se às amostras dos perfis 2 e 3 realizados na Ilha de Anavilhanas (Figura 60). Foram coletadas amostras nas áreas montante, central e jusante do arquipélago.

Tabela 9 - Resultado das Análises Granulométricas para os Diques Longitudinais (baseada em Wentworth, 1922):

\begin{tabular}{|c|c|c|c|c|c|c|c|c|c|c|}
\hline \multirow[t]{2}{*}{ Amostra } & \multirow[t]{2}{*}{ Localização } & \multicolumn{3}{|c|}{$\begin{array}{c}\text { Composição } \\
\text { Granulométrica }(\%)\end{array}$} & \multicolumn{6}{|c|}{$\begin{array}{c}\text { Distribuição da Fração Areia } \\
(\%)\end{array}$} \\
\hline & & $\begin{array}{c}\text { areia } \\
\text { total }\end{array}$ & silte & argila & grânulos & $\begin{array}{c}\text { areia } \\
\text { muito } \\
\text { grossa }\end{array}$ & $\begin{array}{c}\text { areia } \\
\text { grossa }\end{array}$ & $\begin{array}{l}\text { areia } \\
\text { media }\end{array}$ & $\begin{array}{l}\text { areia } \\
\text { fina }\end{array}$ & $\begin{array}{c}\text { areia } \\
\text { muito } \\
\text { fina }\end{array}$ \\
\hline ANA_21 & $\begin{array}{l}\text { Ilha região do } \\
\text { baixote } \\
\text { (montante) }\end{array}$ & 46,65 & 50,35 & 3,00 & 0,00 & 0,00 & 0,25 & 0,35 & 7,15 & 38,90 \\
\hline ANA_2 & $\begin{array}{l}\text { Ilha das } \\
\text { Anavilhanas } \\
\text { (área central) }\end{array}$ & 14,80 & 54,70 & 30,5 & 0,00 & 0,00 & 0,10 & 0,25 & 2,85 & 11,60 \\
\hline ANA_7 & $\begin{array}{l}\text { Ilha do Sapato } \\
\text { (área central) }\end{array}$ & 6,85 & 45,15 & 48,00 & 0,00 & 0,00 & 0,00 & 0,10 & 0,15 & 6,60 \\
\hline ANA_24 & Ilha jusante & 18,45 & 48,55 & 33,00 & 0,55 & 0,15 & 0,25 & 0,50 & 1,45 & 15,55 \\
\hline ANA_22 & Ilha jusante & 6,95 & 55,05 & 38,00 & 0,20 & 0,20 & 0,25 & 0,25 & 1,00 & 5,05 \\
\hline ANA_23 & Ilha jusante & 0,95 & 71,05 & 28,00 & 0,00 & 0,00 & 0,00 & 0,25 & 0,70 & 0,00 \\
\hline
\end{tabular}

\footnotetext{
${ }^{7}$ Assim denominados apenas no final da investigação
} 


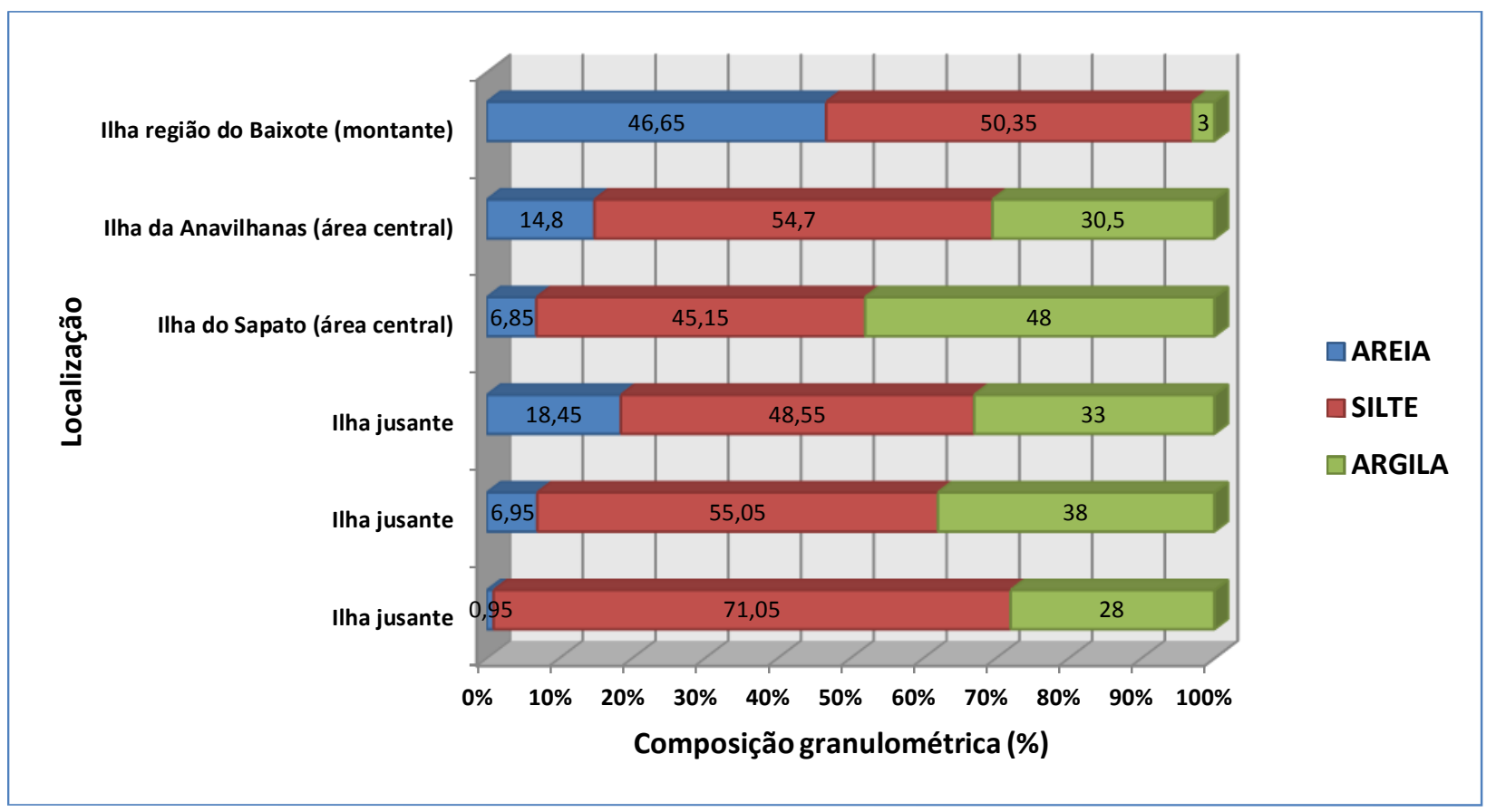

Figura 60: Diagrama de barras de distribuição de frequência das frações granulométricas dos diques longitudinais.

Quadro 18: Classe textural e Tipo de sedimentos para os Diques Longitudinais de acordo com a classificação de Flemming (2000)

\begin{tabular}{|l|c|l|l|}
\hline Amostra & Código & \multicolumn{1}{|c|}{ Classe Textural } & \multicolumn{1}{|c|}{ Tipo de Sedimento } \\
\hline ANA_2 & D-III & lama levemente arenosa siltosa & Lama Levemente Arenosa \\
\hline ANA_7 & D-IV & lama levemente arenosa argilosa & Lama Levemente Arenosa \\
\hline ANA_21 & C-I & $\begin{array}{l}\text { lama arenosa extremamente } \\
\text { siltosa }\end{array}$ & Lama Arenosa \\
\hline ANA_22 & D-IV & lama levemente arenosa argilosa & Lama Levemente Arenosa \\
\hline ANA_23 & E-III & silte argiloso & Lama \\
\hline ANA_24 & D-III & lama levemente arenosa siltosa & Lama Levemente Arenosa \\
\hline
\end{tabular}

Os sedimentos lamosos que constituem os diques longitudinais não mostram evidências de estratitificação causadas por seleção de tamanho de partículas na fase de sua deposição (Figura 61). Assim, as estruturas sedimentares observadas restringem-se a estruturas de bioturbação atuais e não necessariamente contemporâneas à sedimentação destes finos que sustentam a morfologia dos diques. Estas abragem feições produzidas pelas atividades, em vida, dos animais (zooturbação) e plantas (fitoturbação) no interior ou nas superfícies dos depósitos sedimentares (SUGUIO, 2003). 

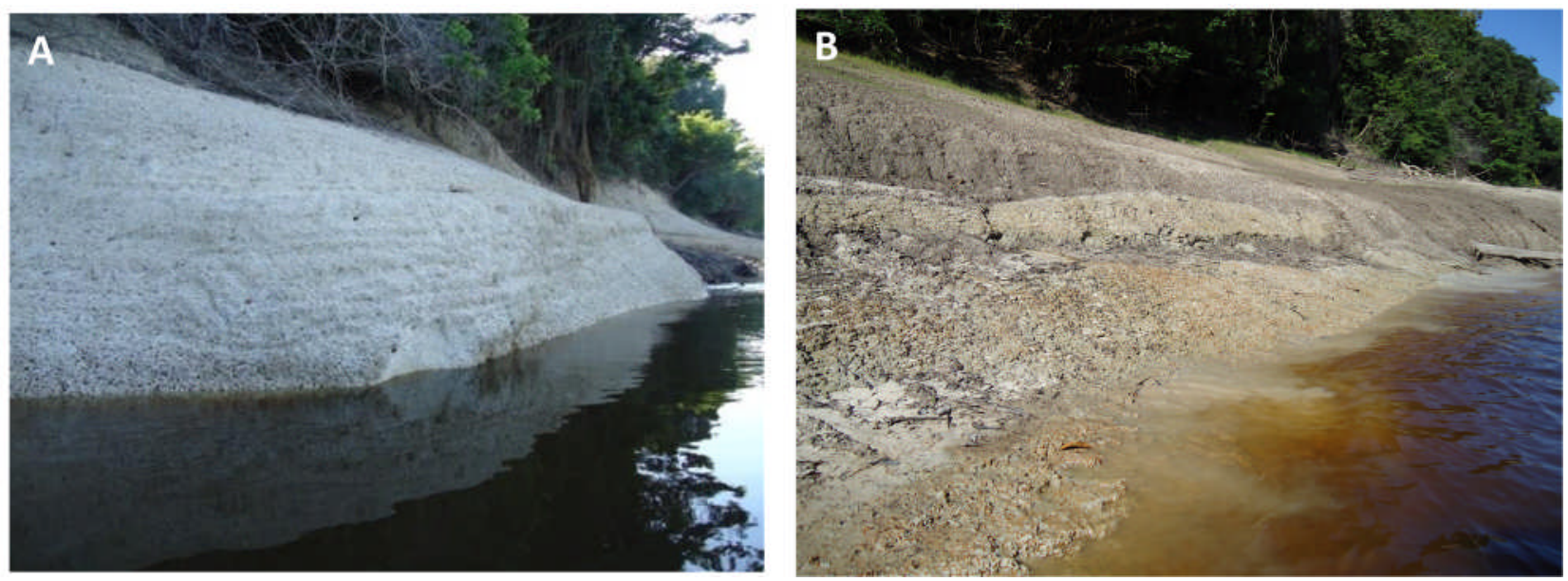

Figura 61: A: Dique Longitudinal - Lama Levemente Arenosa; B: Dique Longitudinal - Lama Arenosa.

As estruturas de bioturbação identificadas nos diques longitudinais são atribuídas a animais bentônicos, os viventes no interior dos sedimentos (infauna), e a vegetação, fato analisado devido a presença abundante de raízes. No caso de animais, foram identificadas pequenas cavidades produzidas por microorganismos (infauna) dando um aspecto mosqueado (manchado). A presença de raízes é abundante em todas as ilhas atingindo profundidades máximas de até 1 metro, e fornecendo um mosqueado amarelo ao pacote sedimentar (Figura 62).
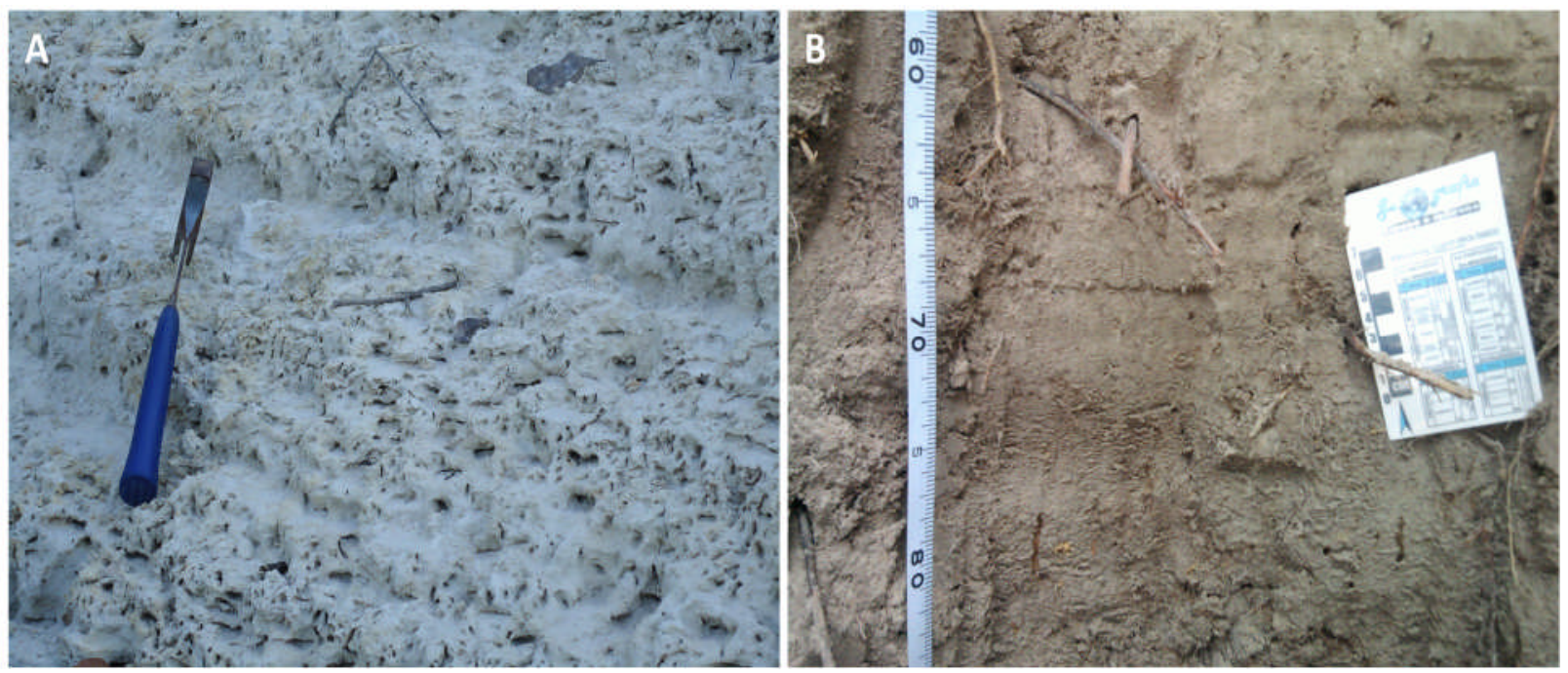

Figura 62: Estruturas de bioturbação nos sedimentos dos diques longitudinais. A: Bioturbação produzida em material argiloso pela infauna; B: Bioturbação produzida em material síltico-arenoso por raízes das plantas (fitoturbação) (imagens da autora)

A descrição dos perfis e a análise dos pontos evidenciaram a seguinte distribuição espacial dos materiais nas unidades denominadas de diques: os sedimentos lamosos (Lama 
Levemente Arenosa e Lama Arenosa) que representam os materiais predominantes na sua constituição distribuem-se de forma longitudinal desde as regiões de promontórios destes até a sua porção distal, em que fica subjacente a coberturas de areias muito finas. Estas referemse a sedimentos do tipo Areia Lamosa e Areia Levemente Lamosa que se distribuem nos diques acima dos sedimentos lamosos e de forma descontínua, predominando nas porções médias e distais desses diques, sendo que a transição entre estes pacotes sedimentares ocorre de forma abrupta. Este material arenoso ocorre nas porções norte e sul do complexo e são mais abundantes nos diques topograficamente mais baixos. Estas características permitem o raciocínio de que há discordância deposicional entre estes pacotes, demonstrando possibilidade de ter ocorrido um hiato espaço-temporal no ambiente deposicional.

\subsubsection{Lagos}

Nas zonas marginais dos lagos também foram coletadas amostras para análises granulométricas e caracterização dos materiais. No total foram amostrados 04 lagos localizados na área central do complexo próximos a localidade de Novo Airão, com coleta de 07 amostras. As classes texturais encontradas foram argila siltosa, lama levemente arenosa siltosa e lama levemente arenosa argilosa (Figura 63), caracterizando sedimentos do tipo Lama e Lama Levemente Arenosa (Tabela 10 e Quadro 19). Aqui com predomínio da fração argila configurando ambientes deposicionais de baixa energia. As ocorrências de estruturas sedimentares secundárias do tipo "gretas de contração" confirmam, em campo, o predomínio desta fração.

Tabela 10 - Resultado das Análises Granulométricas Lagos (baseada em Wentworth, 1922):

\begin{tabular}{|c|c|c|c|c|c|c|c|c|c|c|}
\hline \multirow[t]{2}{*}{ Amostra } & \multirow[t]{2}{*}{ Localização } & \multicolumn{3}{|c|}{$\begin{array}{c}\text { Composição } \\
\text { Granulométrica }(\%)\end{array}$} & \multicolumn{6}{|c|}{$\begin{array}{c}\text { Distribuição da Fração Areia } \\
(\%)\end{array}$} \\
\hline & & $\begin{array}{c}\text { areia } \\
\text { total }\end{array}$ & silte & argila & grânulos & $\begin{array}{c}\text { areia } \\
\text { muito } \\
\text { grossa }\end{array}$ & $\begin{array}{c}\text { areia } \\
\text { grossa }\end{array}$ & $\begin{array}{c}\text { areia } \\
\text { media }\end{array}$ & $\begin{array}{l}\text { areia } \\
\text { fina }\end{array}$ & $\begin{array}{c}\text { areia } \\
\text { muito } \\
\text { fina }\end{array}$ \\
\hline ANA_3 & Lago Tamatá & 0,40 & 39,10 & 60,50 & 0,00 & 0,00 & 0,00 & 0,00 & 0,10 & 0,30 \\
\hline ANA_4 & Lago Tamatá & 13,75 & 55,75 & 30,5 & $0,75^{*}$ & 1,40 & 2,00 & 1,20 & 1,25 & 7,15 \\
\hline ANA_5 & $\begin{array}{l}\text { Lago do } \\
\text { Arraia }\end{array}$ & 18,95 & 53,05 & 28,00 & $1,65^{*}$ & 0,85 & 0,85 & 0,65 & 1,20 & 13,75 \\
\hline ANA_6 & $\begin{array}{l}\text { Lago do } \\
\text { Arraia }\end{array}$ & 5,45 & 46,55 & 48,00 & $0,65^{*}$ & 0,00 & 0,00 & 0,40 & 0,40 & 4,00 \\
\hline ANA_8 & Lago Capitari & 8,20 & 48,80 & 43,00 & 0,00 & 0,00 & 0,00 & 0,65 & 0,40 & 7,15 \\
\hline ANA_15 & Lago do Arara & 0,45 & 41,55 & 58,00 & 0,00 & 0,00 & 0,00 & 0,10 & 0,20 & 0,15 \\
\hline ANA_16 & Lago do Arara & 5,80 & 51,20 & 43,00 & 0,00 & 0,10 & 0,15 & 0,55 & 0,65 & 4,35 \\
\hline
\end{tabular}




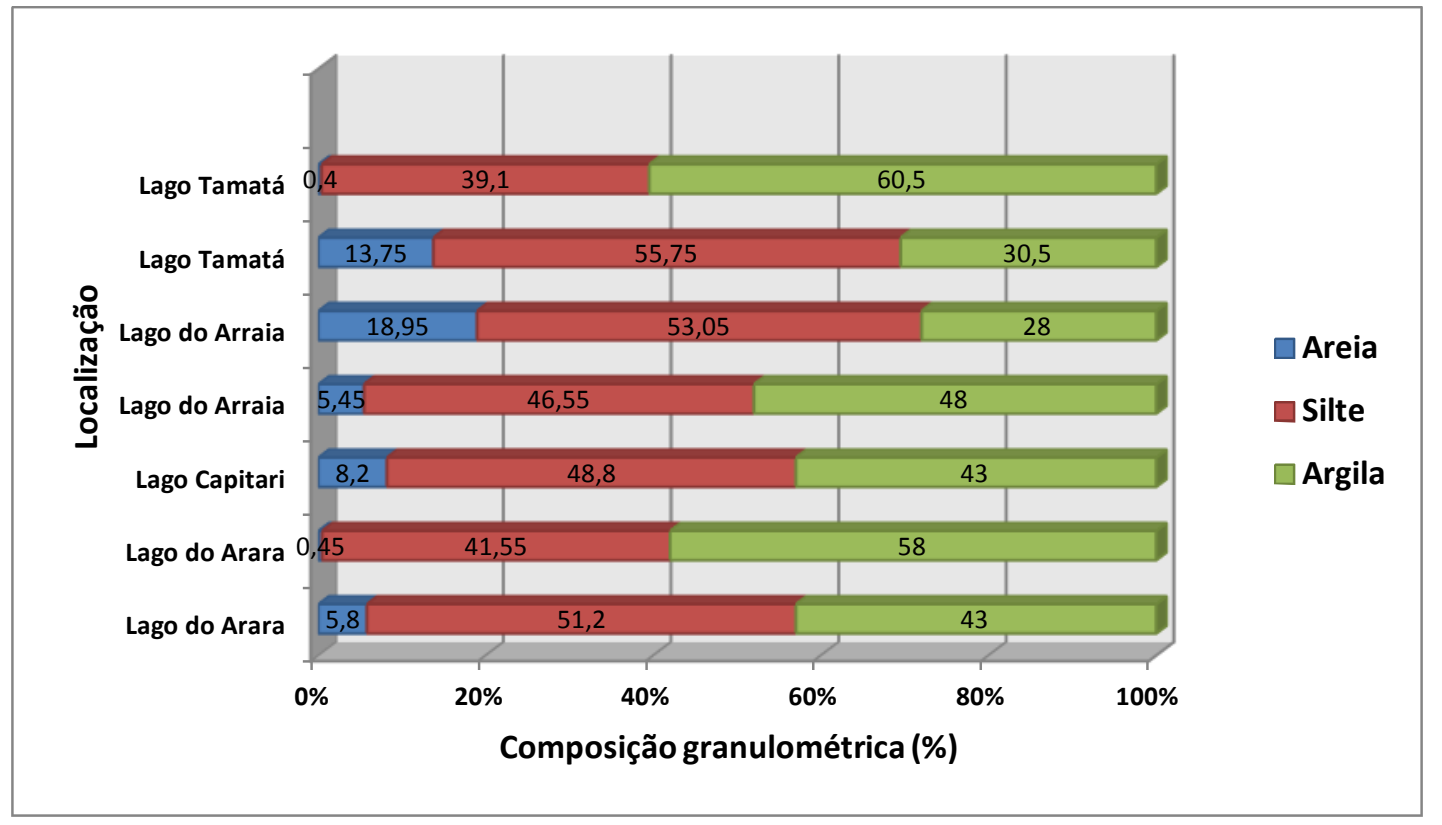

Figura 63: Diagrama de barras de distribuição de frequência das frações granulométricas dos Lagos

Quadro 19: Classe textural e Tipo de sedimentos para os Lagos de acordo com a classificação de Flemming (2000)

\begin{tabular}{|l|l|l|l|}
\hline Amostra & Código & \multicolumn{1}{|c|}{ Classe Textural } & \multicolumn{1}{c|}{ Tipo de Sedimento } \\
\hline ANA_3 & E-IV & argila siltosa & Lama \\
\hline ANA_4 & D-III & lama levemente arenosa siltosa & Lama Levemente Arenosa \\
\hline ANA_5 & D-III & lama levemente arenosa siltosa & Lama Levemente Arenosa \\
\hline ANA_6 & D-IV & lama levemente arenosa argilosa & Lama Levemente Arenosa \\
\hline ANA_8 & D-III & lama levemente arenosa siltosa & Lama Levemente Arenosa \\
\hline ANA_15 & E-IV & argila siltosa & Lama \\
\hline ANA_16 & D-III & lama levemente arenosa siltosa & Lama Levemente Arenosa \\
\hline
\end{tabular}

No ambiente flúvio-lacustre foram identificadas estruturas sedimentares do tipo Gretas de Contração que se formam durante o período da vazante, quando ocorre o rebaixamento do N.A, expondo o material argiloso a consequentes ressecações e formação destas (Figura 64). Nos lagos, a exemplo do Lago Tamatá, durante a vazante o material em suspensão é depositado devido à ausência de corrente e/ou redução da velocidade desta e decanta sobre a matéria orgânica do fundo do lago, formando assim as gretas. Estas apresentam as seguintes características: concentração de matéria orgânica em sua base, principalmente vegetação em decomposição, e polígonos com tamanho aproximado de $12 \mathrm{~cm}$, espessura de $2 \mathrm{~cm}$ e fendas de $3 \mathrm{~cm}$. Gretas de contração também foram observadas nas áreas marginais dos grandes 
lagos formados na porção terminal de Anavilhanas, represados pelas ilhas alongadas que predominam no local. Neste caso, as gretas são maiores que as dos lagos localizados à montante, com polígonos de tamanho aproximado de 35 centímetros e fendas de $3 \mathrm{~cm}$. Segundo Bigarella (2003), o tamanho do polígono está relacionado com a espessura da camada sedimentar que está sendo desidratada, ou seja, neste caso o pacote argiloso é mais espesso do que as ocorrências localizadas a montante no arquipélago, com uma espessura de 6 $\mathrm{cm}$, ou seja três vezes maior.

Nas zonas marginais também foram identificadas a formação de "pelotas" de argilas, que se distribuem nas margens dos lagos e possuem dimensão centimétrica variável. 

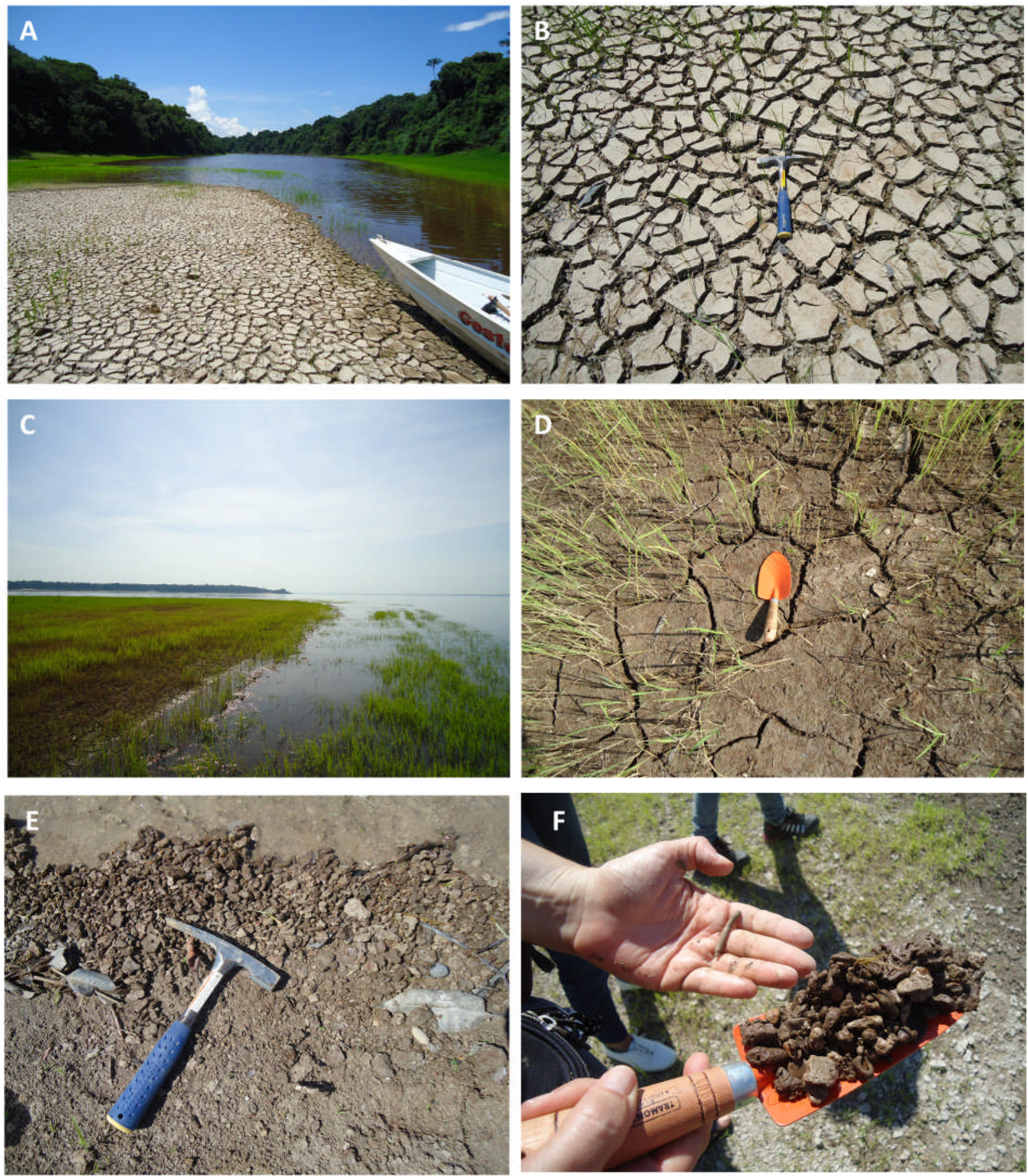

Figura 64: Gretas de Contração. A: Exposição no Lago do Tamatá; B: Detalhe da estrutura localizada no Lago do Tamatá; C: Gretas de contração, extremo sul de Anavilhanas; D: Detalhe das gretas. Observar tamanho maior quando comparado com as gretas da prancha B; E: Pelotas de argilas na margem dos lagos; F: Detalhe das pelotas de argila. (imagens da autora). 


\subsubsection{Barras fluviais centrais e laterais}

Nas áreas de ocorrência das barras fluviais centrais e laterais também foi realizada coleta de material, num total de 06 amostras, para análise granulométrica (Tabela 11 e Figura 65). Nestas morfologias a fração predominante foi areia. A classe textural predominante foi areia, e duas amostras foram classificadas como areia levemente siltosa. Os tipos de sedimentos identificados foram Areia e Areia Levemente Lamosa (Quadro 20).

Tabela 11 - Resultado das Análises Granulométricas das Barras fluviais centrais e laterais (baseada em Wentworth, 1922):

\begin{tabular}{|c|c|c|c|c|c|c|c|c|c|c|}
\hline \multirow[t]{2}{*}{ Amostra } & \multirow[t]{2}{*}{ Localização } & \multicolumn{3}{|c|}{$\begin{array}{c}\text { Composição } \\
\text { Granulométrica }(\%) \\
\end{array}$} & \multicolumn{6}{|c|}{$\begin{array}{c}\text { Distribuição da Fração Areia } \\
(\%)\end{array}$} \\
\hline & & $\begin{array}{c}\text { areia } \\
\text { total }\end{array}$ & silte & argila & grânulos & $\begin{array}{c}\text { areia } \\
\text { muito } \\
\text { grossa }\end{array}$ & $\begin{array}{c}\text { areia } \\
\text { grossa }\end{array}$ & $\begin{array}{c}\text { areia } \\
\text { media }\end{array}$ & $\begin{array}{c}\text { areia } \\
\text { fina }\end{array}$ & $\begin{array}{c}\text { areia } \\
\text { muito } \\
\text { fina }\end{array}$ \\
\hline ANA_17 & $\begin{array}{l}\text { Barra fluvial } \\
\text { central - Praia } \\
\text { do Baixote } \\
\text { (montante) }\end{array}$ & 97,45 & 2,05 & 0,50 & 0,00 & 1,60 & 18,05 & 39,90 & 37,35 & 0,40 \\
\hline ANA_28 & $\begin{array}{l}\text { Barra fluvial } \\
\text { central - Praia } \\
\text { do Baixote } \\
\text { (montante) }\end{array}$ & 99,75 & 0,00 & 0,25 & 4,10 & 5,25 & 16,40 & 34,85 & 36,45 & 2,70 \\
\hline ANA_14 & $\begin{array}{l}\text { Barra fluvial } \\
\text { central - Praia } \\
\text { do Arara (área } \\
\text { central) }\end{array}$ & 99,25 & 0,75 & 0,00 & 0,00 & 0,25 & 6,35 & 37,90 & 48,45 & 6,30 \\
\hline ANA_13 & $\begin{array}{lr}\text { Barra } & \text { fluvial } \\
\text { lateral } & \text { Praia } \\
\text { Ponta r do } \\
\text { Cavalo (área } \\
\text { central) }\end{array}$ & 90,35 & 9,15 & 0,50 & 0,00 & 8,00 & 38,25 & 20,85 & 18,75 & \\
\hline ANA_1 & $\begin{array}{l}\text { Barra fluvial } \\
\text { central - Praia } \\
\text { do Meio (área } \\
\text { central) }\end{array}$ & 88,95 & 11,05 & 0,00 & 0,35 & 2,25 & 12,20 & 20,45 & 50,40 & 3,30 \\
\hline ANA_25 & $\begin{array}{l}\text { Barra fluvial } \\
\text { lateral } \\
\text { (jusante) }\end{array}$ & 98,25 & 0,75 & 0,00 & 0,00 & 0,00 & 14,00 & 50,80 & 33,45 & 0,00 \\
\hline
\end{tabular}




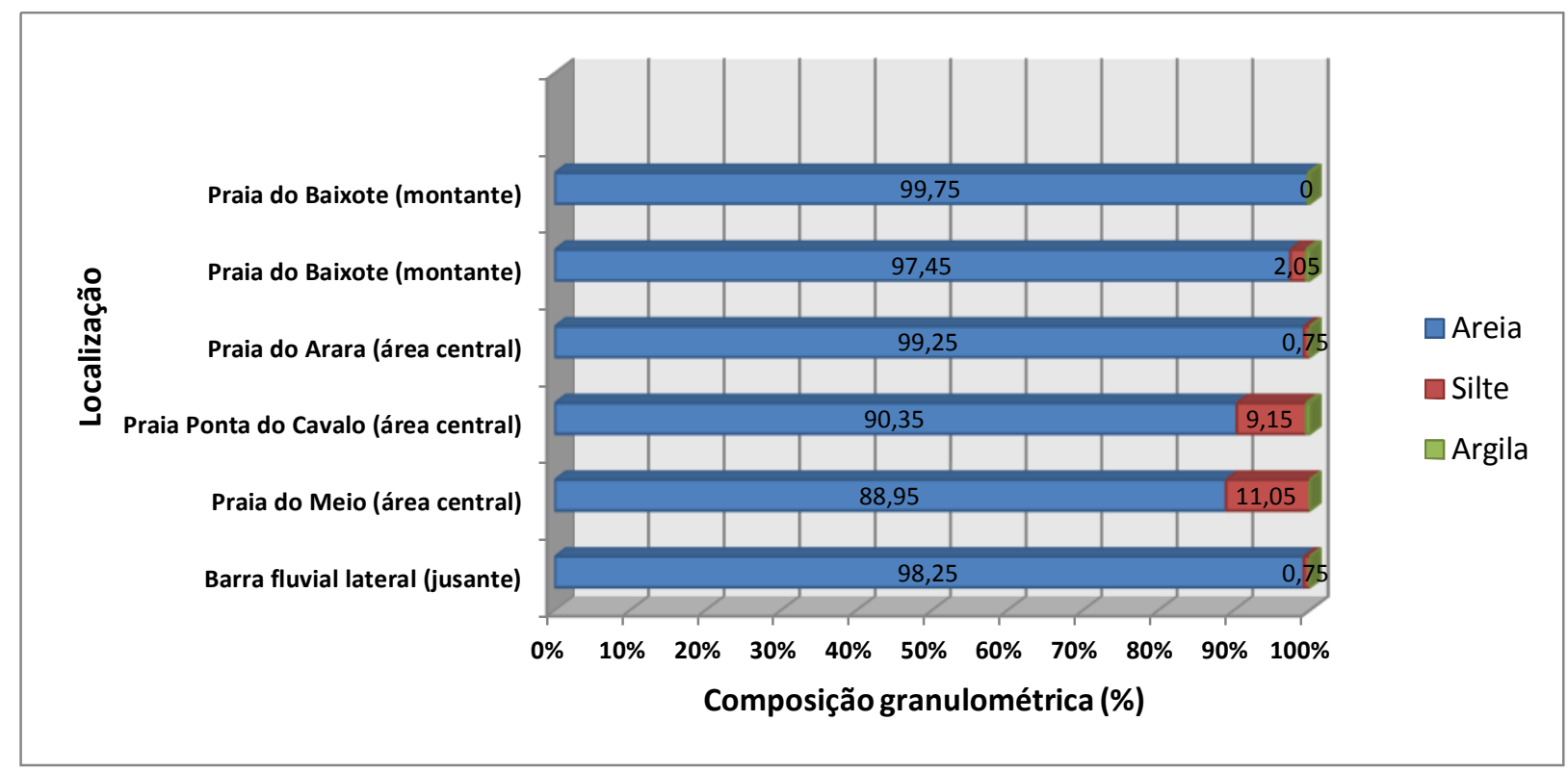

Figura 65: Diagrama de barras de distribuição de frequência das frações granulométricas das Barras Fluviais Centrais e Laterais

Quadro 20: Classe textural e Tipo de sedimentos para as Barras fluviais centrais e laterais de acordo com a classificação de Flemming (2000)

\begin{tabular}{|l|c|l|l|}
\hline Amostra & Código & \multicolumn{1}{|c|}{ Classe Textural } & \multicolumn{1}{c|}{ Tipo de Sedimento } \\
\hline ANA_1 & A-I & areia levemente siltosa & Areia Levemente Lamosa \\
\hline ANA_13 & A-I & areia levemente siltosa & Areia Levemente Lamosa \\
\hline ANA_14 & S & areia & Areia \\
\hline ANA_17 & S & areia & Areia \\
\hline ANA_25 & S & areia & Areia \\
\hline ANA_28 & S & areia & Areia \\
\hline
\end{tabular}

As barras fluviais centrais na área estudada ocorrem principalmente de fronte aos promontórios e à jusante das ilhas fluviais e emergem principalmente durante o período de vazante do rio Negro. As frações granulométricas que predominam estão na faixa da areia média à areia fina.

Este material é habitualmente transportado e depositado pelo rio como carga de fundo. As barras fluviais laterais também são constituídas predominantemente por areias sendo que nestes foram identificadas areias de granulação mais grossa em relação às areias depositadas nos diques longitudinais. As barras fluviais laterais localizam-se na confluência dos igarapés com o Negro, tanto na margem direita como na esquerda. $\mathrm{O}$ suprimento de areia é fornecido 
pelos igarapés que seleciona e transporta este material erodido das vertentes da Terra firme. Os processos de transporte e de deposição que ocorrem nestas barras são dinâmicos, modificando suas formas ao longo dos anos. Ocorrem durante o período da cheia quando o rio principal represa o igarapé constituindo rias fluviais de padrão dendrítico. Nestas unidades morfológicas foram identificadas a presença de vegetação herbácea de menor porte que a mata de terra firme e de igapó.

As estruturas sedimentares presentes nestas barras incluem as marcas onduladas, nas barras fluviais centrais, tanto como micro-ondulações (marcas de ondas) como macroondulações (Dunas).

As micro-ondulações ou marcas ondulares são formas com perfil aproximadamente triangular, possuindo declividades suaves em direção de montante e sendo íngremes para jusante. Possuem altura de poucos centímetros e comprimento de até dois decímetros, em geral são compostas por material dedrítico fino, mas incluem as areias, sendo que suas dimensões independem da granulometria e da profundidade do fluxo. Correspondendo a formas topográficas de pequena escala, podem compor topografias individualmente caracterizadas ou se desenvolver como superimpostas em formas de escala maior, como no dorso de dunas e antidunas (CHRISTOFOLETTI, 1981 p.216). Em Anavilhanas estas microondulações foram identificadas nas depressões das macro-ondulações (Dunas) em ambiente subaquático (Figura 66).

Estruturas sedimentares do tipo laminação plana também ocorrem nestes sedimentos. Algumas camadas de areia formadoras das macro-ondulações (dunas) nas barras fluviais centrais apresentam laminação plana, alternado-se com camadas de minerais máficos pesados de espessura milimétricas (Figura 67). No ambiente de ocorrência deste tipo de estrutura a areia é classificada como areia média a fina 

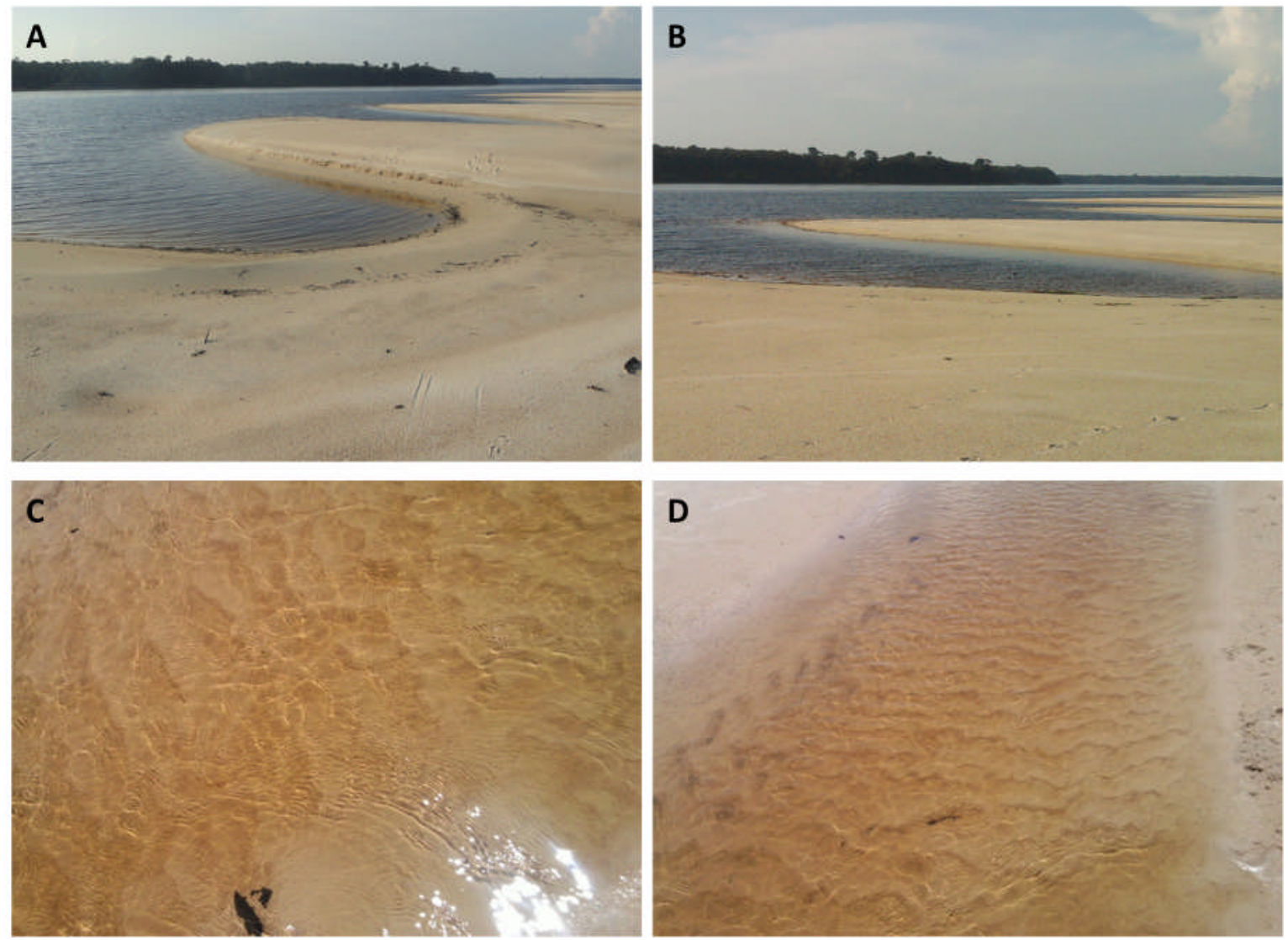

Figura 66: Marcas onduladas. A e B: Dunas localizadas nos cordões fluviais; C e D: mircoondulações localizadas nas depressões das macro-ondulações. (imagens da autora)

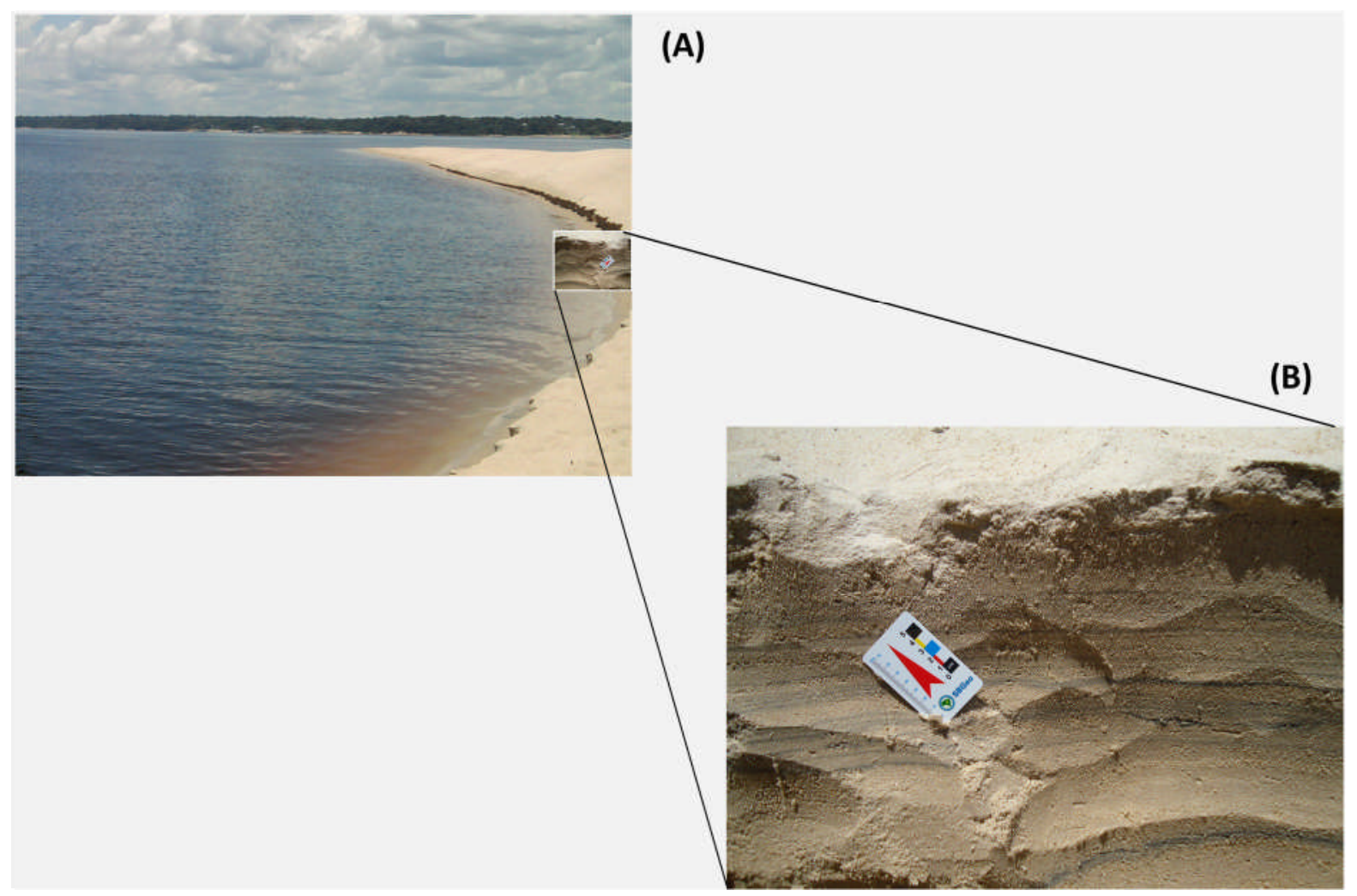

Figura 67: Laminação plana em barra fluvial central na Praia do Meio 


\subsubsection{Terra Firme}

$\mathrm{Na}$ Terra Firme (margens esquerda e direita do rio Negro) foram coletadas algumas amostras para análises granulométricas. No total foram coletadas 05 amostras onde a fração areia predominou (Tabela 12 e Figura 68). As classes texturais identificadas foram lama arenosa siltosa, areia levemente siltosa, lama levemente arenosa siltosa, areia muito siltosa e areia siltosa, e os sedimentos Lama Arenosa, Areia Levemente Lamosa, Lama Levemente Arenosa e Areia Lamosa (Quadro 21).

Tabela 12 - Resultado das Análises Granulométricas Terra Firme (baseada em Wentworth, 1922):

\begin{tabular}{|c|c|c|c|c|c|c|c|c|c|c|}
\hline \multirow[t]{2}{*}{ Amostra } & \multirow[t]{2}{*}{ Localização } & \multicolumn{3}{|c|}{$\begin{array}{c}\text { Composição } \\
\text { Granulométrica }(\%)\end{array}$} & \multicolumn{6}{|c|}{$\begin{array}{c}\text { Distribuição da Fração Areia } \\
(\%)\end{array}$} \\
\hline & & $\begin{array}{c}\text { areia } \\
\text { total } \\
\%\end{array}$ & $\begin{array}{l}\text { silte } \\
\%\end{array}$ & $\underset{\%}{\operatorname{argila}}$ & grânulos & $\begin{array}{l}\text { areia } \\
\text { muito } \\
\text { grossa }\end{array}$ & $\begin{array}{c}\text { areia } \\
\text { grossa }\end{array}$ & $\begin{array}{l}\text { areia } \\
\text { media }\end{array}$ & $\begin{array}{c}\text { areia } \\
\text { fina }\end{array}$ & $\begin{array}{c}\text { areia } \\
\text { muito } \\
\text { fina }\end{array}$ \\
\hline ANA_9 & $\begin{array}{l}\text { Margem } \\
\text { esquerda }\end{array}$ & 37,25 & 37,25 & 25,50 & 0,00 & 0,50 & 3,55 & 9,90 & 14,65 & 8,65 \\
\hline ANA_10 & $\begin{array}{l}\text { Margem } \\
\text { esquerda }\end{array}$ & 75,55 & 13,95 & 10,50 & 0,00 & 2,45 & 20,85 & 33,80 & 18,00 & 0,45 \\
\hline ANA_11 & $\begin{array}{l}\text { Margem } \\
\text { esquerda }\end{array}$ & 20,40 & 44,10 & 35,50 & 0,00 & 0,40 & 2,05 & 5,75 & 11,45 & 0,75 \\
\hline ANA_19 & $\begin{array}{l}\text { Margem } \\
\text { direita }\end{array}$ & 64,7 & 29,80 & 5,50 & 0,55 & 4,65 & 19,50 & 17,65 & 14,50 & 7,85 \\
\hline ANA_20 & $\begin{array}{l}\text { Margem } \\
\text { direita }\end{array}$ & 72,05 & 14,95 & 13,00 & 6,35 & 16,85 & 23,25 & 14,45 & 10,95 & 0,20 \\
\hline
\end{tabular}

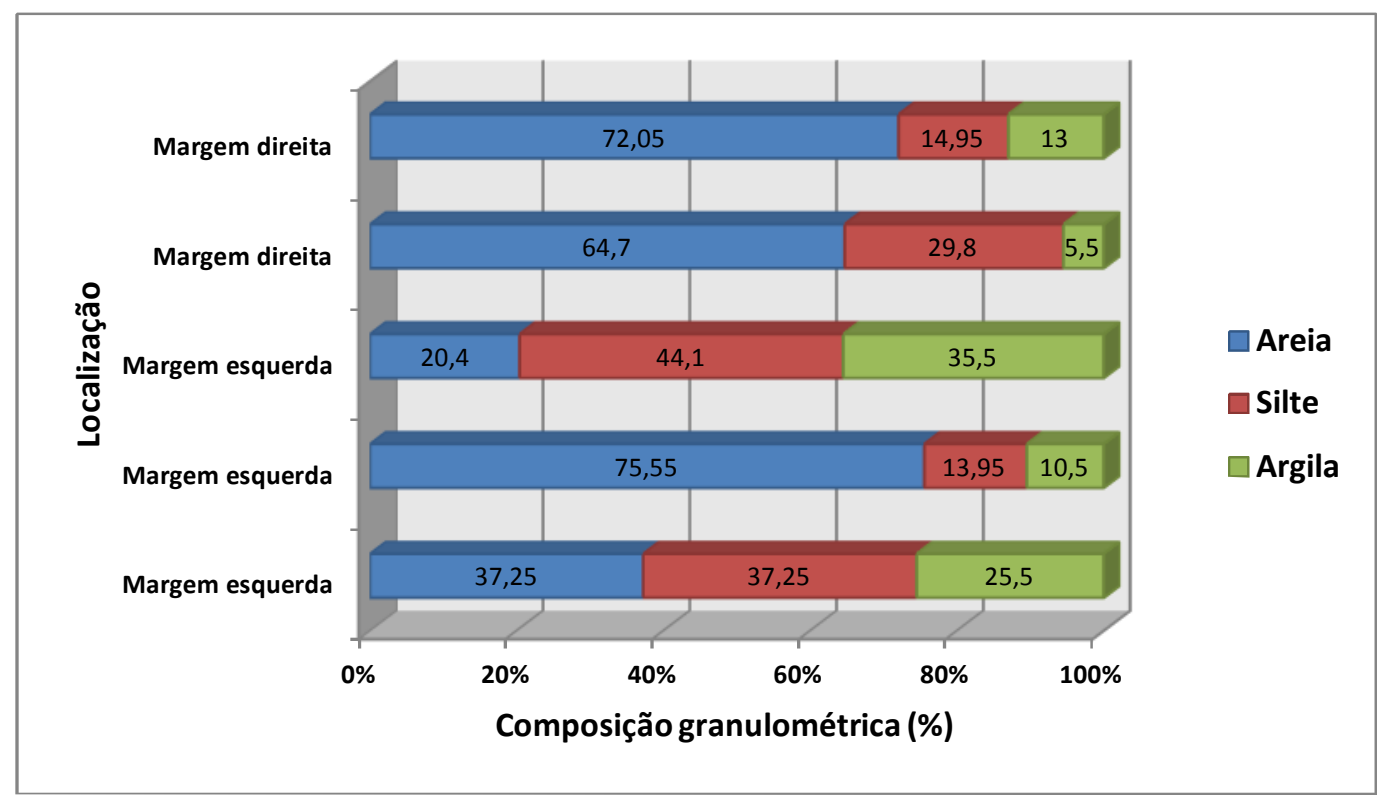

Figura 68: Diagrama de barras de distribuição de frequência das frações granulométricas da Terra Firme 
Quadro 21: Classe textural e Tipo de sedimentos para a Terra Firme de acordo com a classificação de Flemming (2000)

\begin{tabular}{|l|c|l|l|}
\hline Amostra & Código & \multicolumn{1}{|c|}{ Classe Textural } & \multicolumn{1}{c|}{ Tipo de Sedimento } \\
\hline ANA_9 & C-III & lama arenosa siltosa & Lama Arenosa \\
\hline ANA_10 & A-I & areia levemente siltosa & Areia Levemente Lamosa \\
\hline ANA_11 & D-III & lama levemente arenosa siltosa & Lama Levemente Arenosa \\
\hline ANA_19 & B-I & areia muito siltosa & Areia Lamosa \\
\hline ANA_20 & B-II & areia siltosa & Areia Lamosa \\
\hline
\end{tabular}

Estruturas sedimentares do tipo Estratificação plano-paralela e estruturas de bioturbação foram observadas nos sedimentos arenosos da Formação Alter do Chão, na Terra Firme. Nestes sedimentos a estratificação plano-paralela forma camadas intercaladas e estratificadas de material arenoso com material argiloso, com intensa coloração vermelha (Figura 69).

As estruturas de bioturbação descritas na Terra Firme foram formadas por animais superficiais (epifauna), conhecidas regionalmente como "buracos de bodó", produzidas pelo Acari-bodó (liposarcus pordolis). Estas estruturas foram descritas na margem direita do rio Negro, e formam-se durante as enchentes do rio quando os animais criam abertura nas paredes dos barrancos com aproximadamente $20 \mathrm{~cm}$ de diâmetro. Após a vazante estas perfurações ficam à mostra servindo de abrigo para outros animais. Há uma hipótese que estas estruturas também podem ter sido geradas pelas atividades de outros animais.

Ao agrupar, no Diagrama de Flemming (Figura 70), os resultados das análises granulométricas dos materiais dos diversos ambientes deposicionais para a área do Arquipélago de Anavilhanas podem ser distintas três nuvens de conjunto de amostras: um primeiro grupo caracterizado por sedimentos do tipo Areia e Areia Levemente Lamosa; um segundo grupo caracterizado por sedimentos do tipo Areia Lamosa e Lama Arenosa; e finalmente um terceiro conjunto de sedimentos do tipo Lama Arenosa, Lama Levemente Arenosa e Lama, refletindo condições hidrodinâmicas de menor energia do eixo da areia em direção aos eixos silte/argila. Caracterizando assim, os ambientes de deposição dos lagos e ilhas fluviais de menor energia e condições de maior energia na deposição dos depósitos das barras fluviais centrais e laterais. 

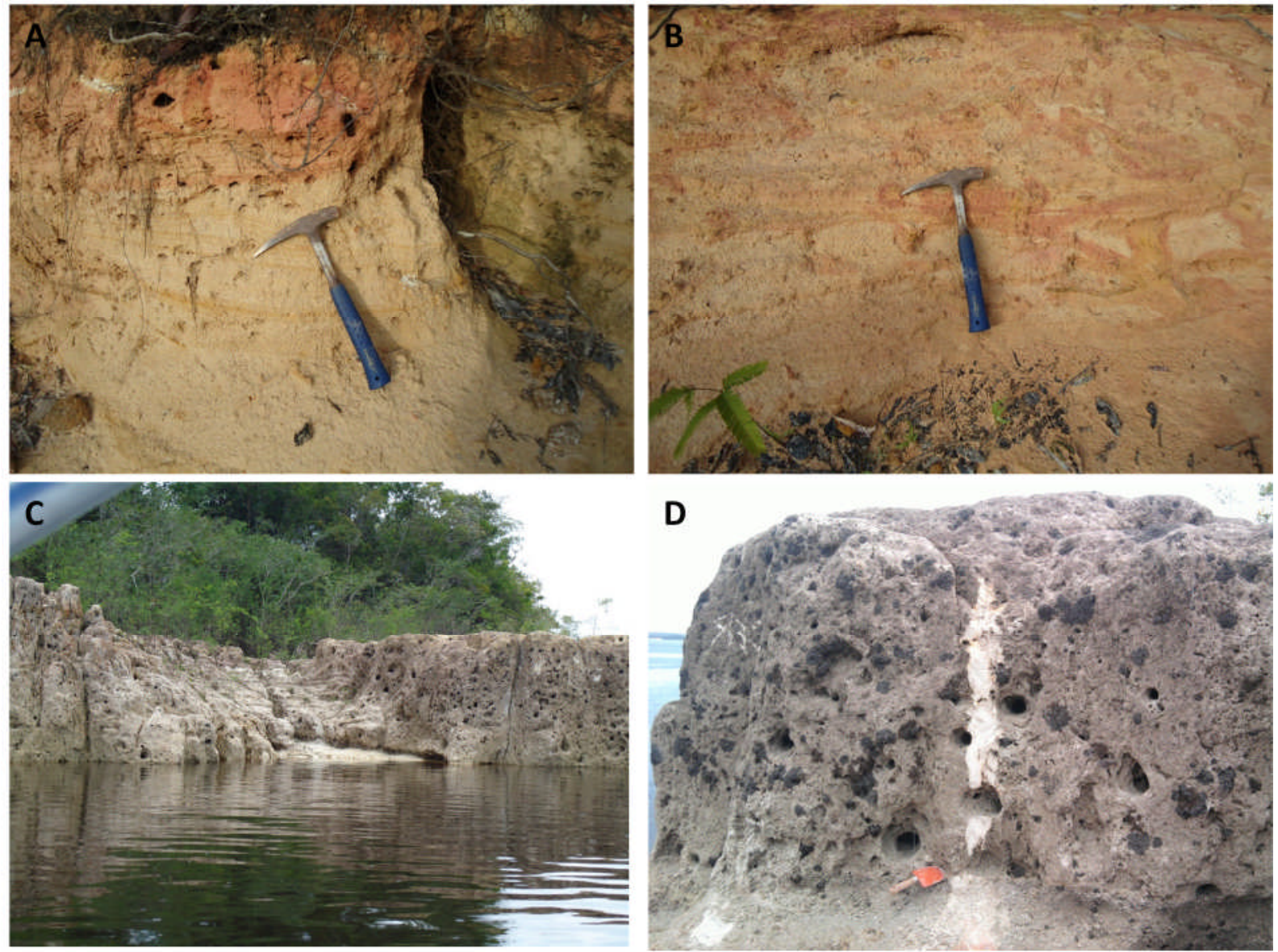

Figura 69: A e B: Estratificação plano-paralela em sedimentos da Formação Alter do Chão - Terra firme; C e D: Estruturas de bioturbação em arenitos da Formação Alter do Chão produzidas por Acaribodó (liposarcus pordolis) (imagens da autora). 


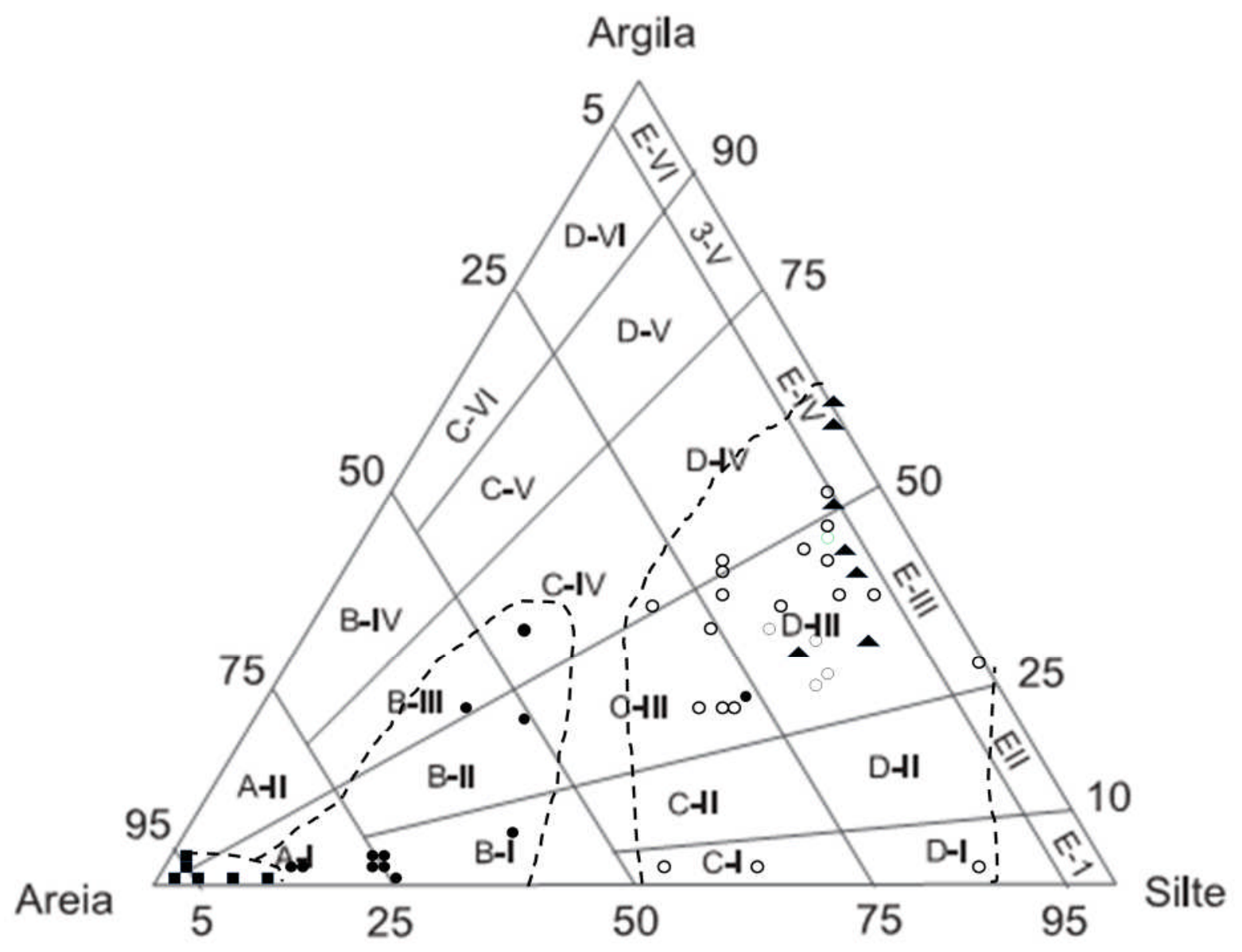

Figura 70: Diagrama de Flemming com as amostras da área de pesquisa

Legenda: Barras fluviais centrais e laterais; OTerra Firme e Perfil 1; OPerfis 2, 3 e 4 e ilhas fluviais; $\Delta$ Lagos. 


\section{MAPEAMENTO E PROCESSOS HIDROMORFODINÂMICOS}

\subsection{MAPEAMENTO HIDROMORFODINÂMICO}

O mapeamento hidromorfodinâmico da área do Complexo de Anavilhanas foi principalmente orientado pela abordagem sistêmica, voltada à análise geomorfológica das formas, processos e materiais predominantes na área e concebido nos moldes das "Cartas Geomorfológicas de Detalhe" (TRICART, 1966). Considerou-se, a princípio, a possibilidade de serem acessados todos os conteúdos que, segundo este autor, seria necessários à produção de uma carta geomorfológica, apesar de se ter como objetivo central o nível interpretativo dos processos atuais ou morfodinâmicos, mais notadamente os hidrodinâmicos. Obteve-se auxílio também em cartas geomorfológicas especialmente produzidas para planícies de origem fluvial no meio tropical úmido, tal como nos estudos de COLTRINARI $(1982,1984)$, ESTAIANO (2007), SANTANA (2007), LUZ (2010), SILVA, J.P. (2012). O texto a seguir apresenta a Carta Geomorfológica do Complexo de Anavilhanas, tratando-se aqui, mais do nível interpretativo, quando se propõem tendências espaciais sobre tipos e balanços de processos hidrodinâmicos nas unidades morfológicas anteriormente descritas. A produção de dados desta pesquisa e sua integração em cartas geomorfológicas também permitiram a elaboração de novas hipóteses a respeito da sequência de processos evolutivos do complexo em fases relativas ao Quaternário, principalmente os relacionados a sistemas e balanços deposicionais e erosivos. Também no nível interpretativo, foi possível discutir a pertinência de se utilizarem os padrões fluviais como referência de síntese para o complexo estudado.

\subsubsection{Carta Geomorfológica do Complexo de Anavilhanas}

A Carta Geomorfológica do Complexo de Anavilhanas na escala 1:100.000 e sua legenda são apresentadas na figura 71. Conforme tratado anteriormente, os conteúdos passam por níveis descritivos, com informações da morfometria, morfografia e da natureza dos materiais superficiais (no caso, materiais sedimentares) e por níveis interpretativos da morfodinâmica (hidrodinâmica), morfogênese e morfocronologia das formas identificadas e mapeadas. Estes conteúdos puderam ser correlacionados numa primeira tentativa de mapeamento e de elaboração de legenda, e posteriormente, puderam ser incrementados, a partir das correlações e interpretações elaboradas sobre a própria carta preliminar. 
A elaboração desta cartografia passou por uma série de etapas, dentre as quais se destacam: a fotoleitura e fotointerpretação de unidades morfológicas, verificação (conteúdos e localização) em imagens de satélite e em imagens de radar das morfologias identificadas, verificação de campo das formas identificadas (conteúdo e localização), levantamento de campo e de gabinete de dados morfométricos das unidades, georreferenciamento e vetorização dos overlays obtidos sobre as fotografias aéreas (ArcView 9.3) e dupla sistematização de legenda. A primeira foi realizada em etapa anterior às análises morfológicas e texturais dos materiais superficiais (descrição de perfis em campo e dos materiais em laboratório) e de análises hidrológicas. A segunda realizou-se a partir dos resultados destas análises correlacionados às morfologias mapeadas, gerando-se as interpretações.

$\mathrm{Na}$ carta e em sua legenda foram agregados os dados e informações obtidos na fase de levantamentos, aí incluídos os bibliográficos, cartográficos, hidroclimatológicos e de campo. A sistematização dos dados obtidos nesses levantamentos subsidiaram a primeira e a segunda proposição de cartografia geomorfológica e de sua legenda, resultando na carta geomorfológica de detalhe da área na qual o aspecto hidromorfodinâmico pode ser ressaltado.

A área mapeada de 212.787 hectares abrangeu parte da UC - PARNA de Anavilhanas, e compreende o trecho anastomosado do canal fluvial do rio Negro próximo a sua foz. O rio Negro é o canal principal e neste trecho apresenta uma largura maior devido ao anastomosamento do arquipélago. Na construção da legenda da carta geomorfológica da área foram seguidas as denominações já regionalmente adotadas para os canais fluviais: rio, paraná, igarapé e furo.

As análises dos tipos de materiais, estruturas sedimentares, formas, tipos de canais, processos (erosivos e/ou deposicionais), eventos de cheias e vazantes do rio Negro, tipo de vegetação, dados hidrológicos e os diferentes tipos de ambiente (Fluvial, Flúvio-lacustre e Terra Firme), deram subsídios relevantes ao mapeamento hidromorfodinâmico da área. Com base nestas análises e na bibliografia disponível a pesquisa apresenta também uma proposta quanto à gênese e à sequência evolutiva das formas e materiais, colaborando para a morfocronologia. 
Mapa Hidromorfodinâmico do Complexo Fluvial de Anavilhanas

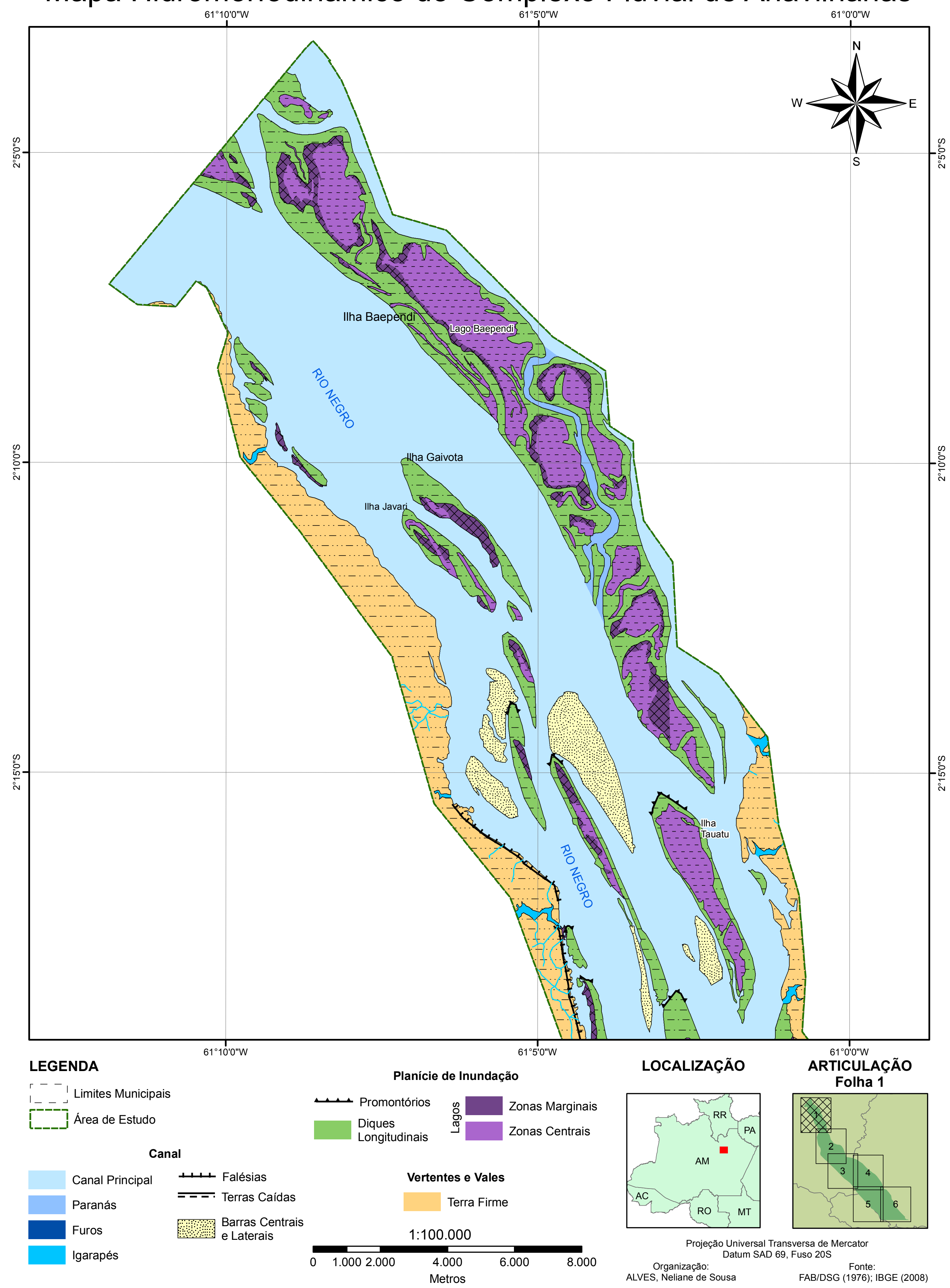




\section{Mapa Hidromorfodinâmico do Complexo Fluvial de Anavilhanas}

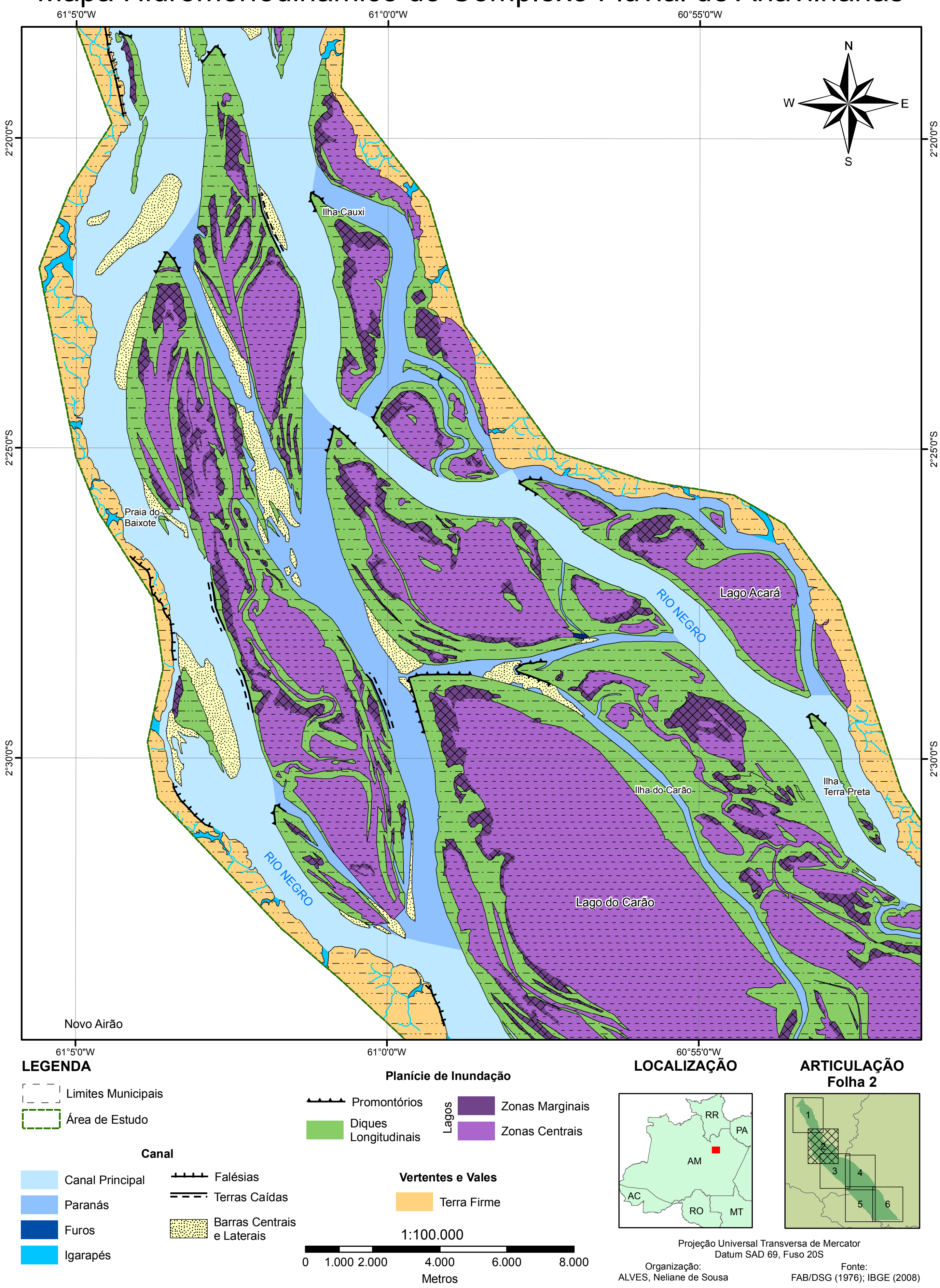




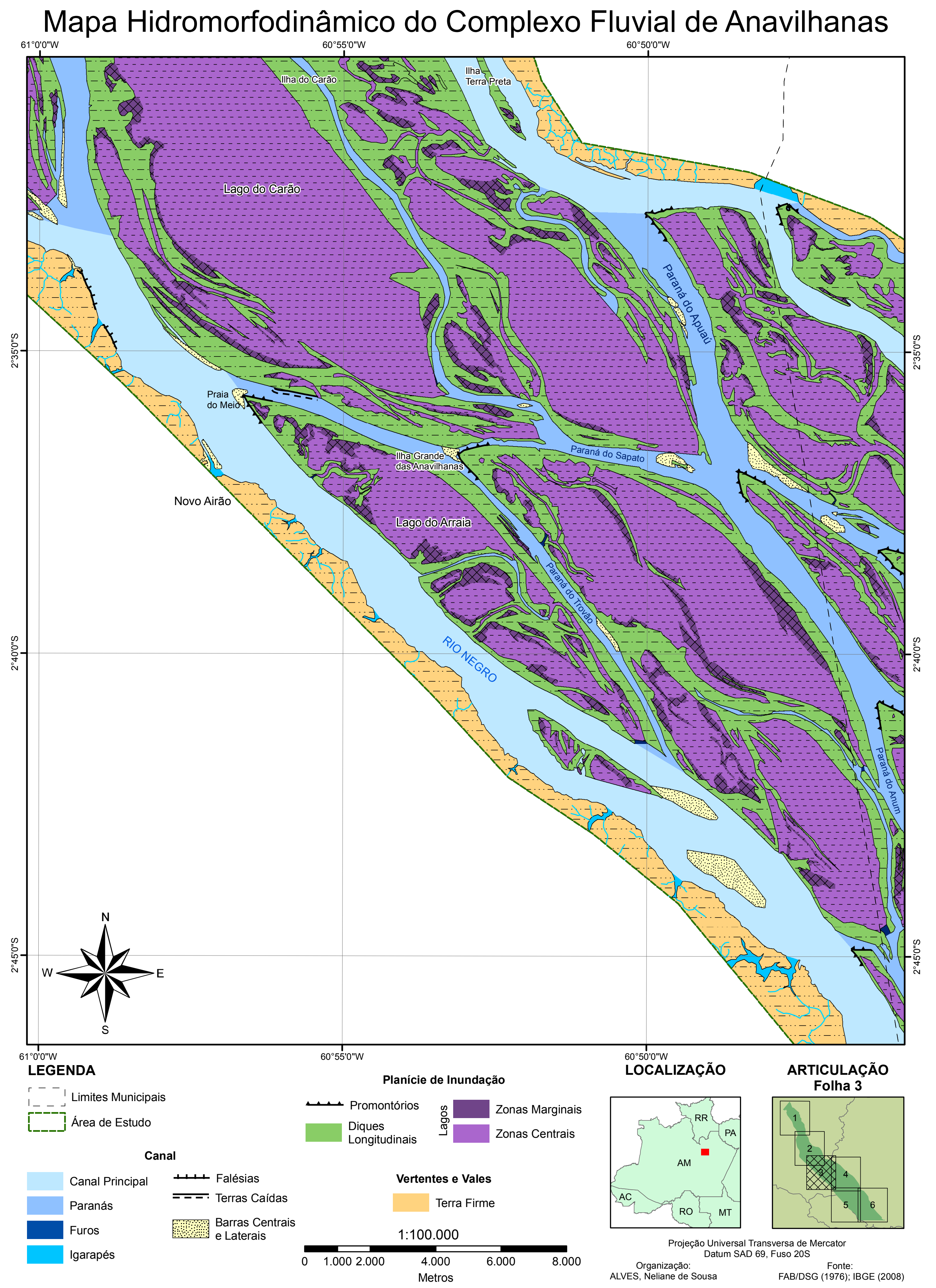




\section{Mapa Hidromorfodinâmico do Complexo Fluvial de Anavilhanas}

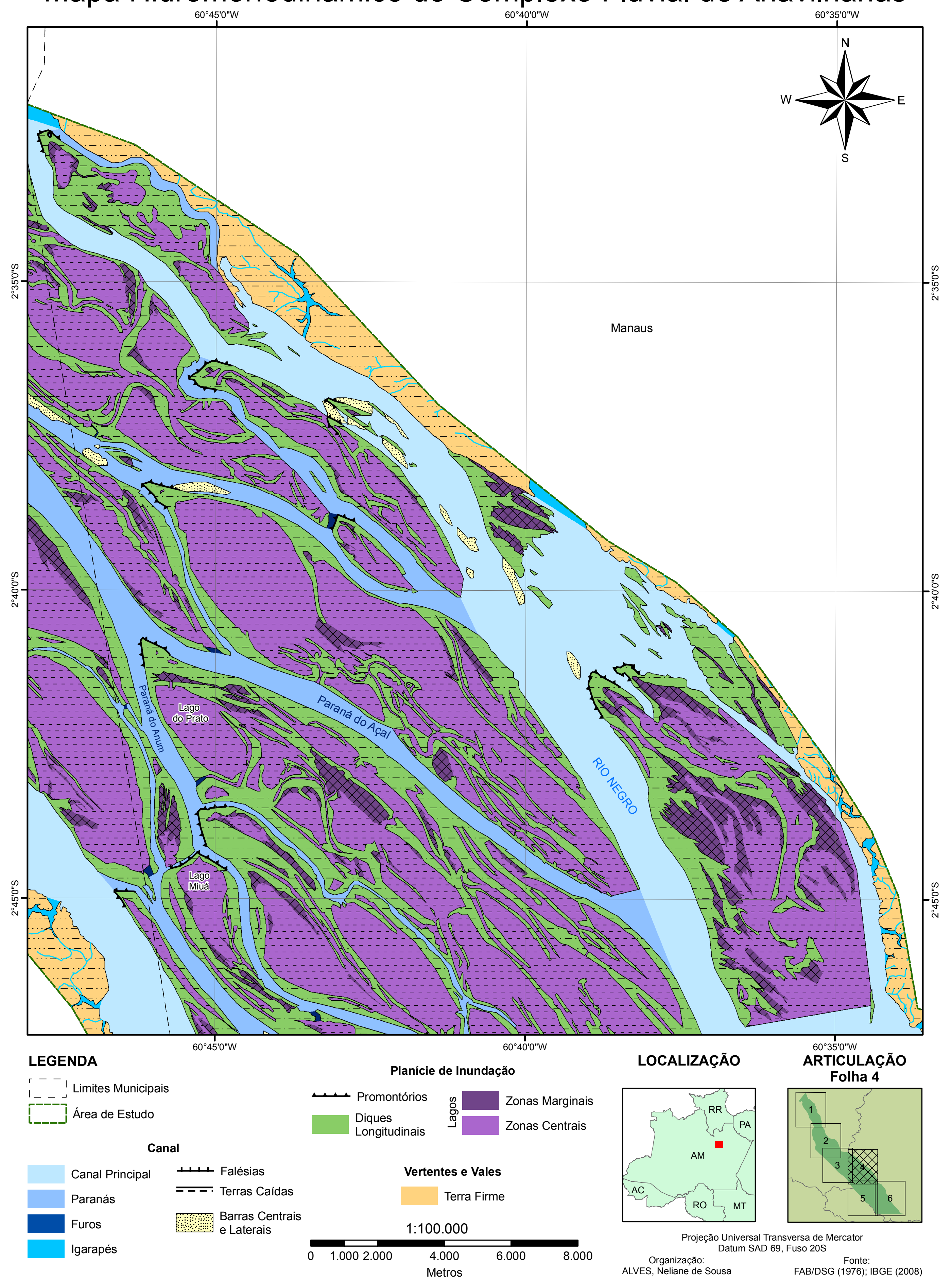




\section{Mapa Hidromorfodinâmico do Complexo Fluvial de Anavilhanas}

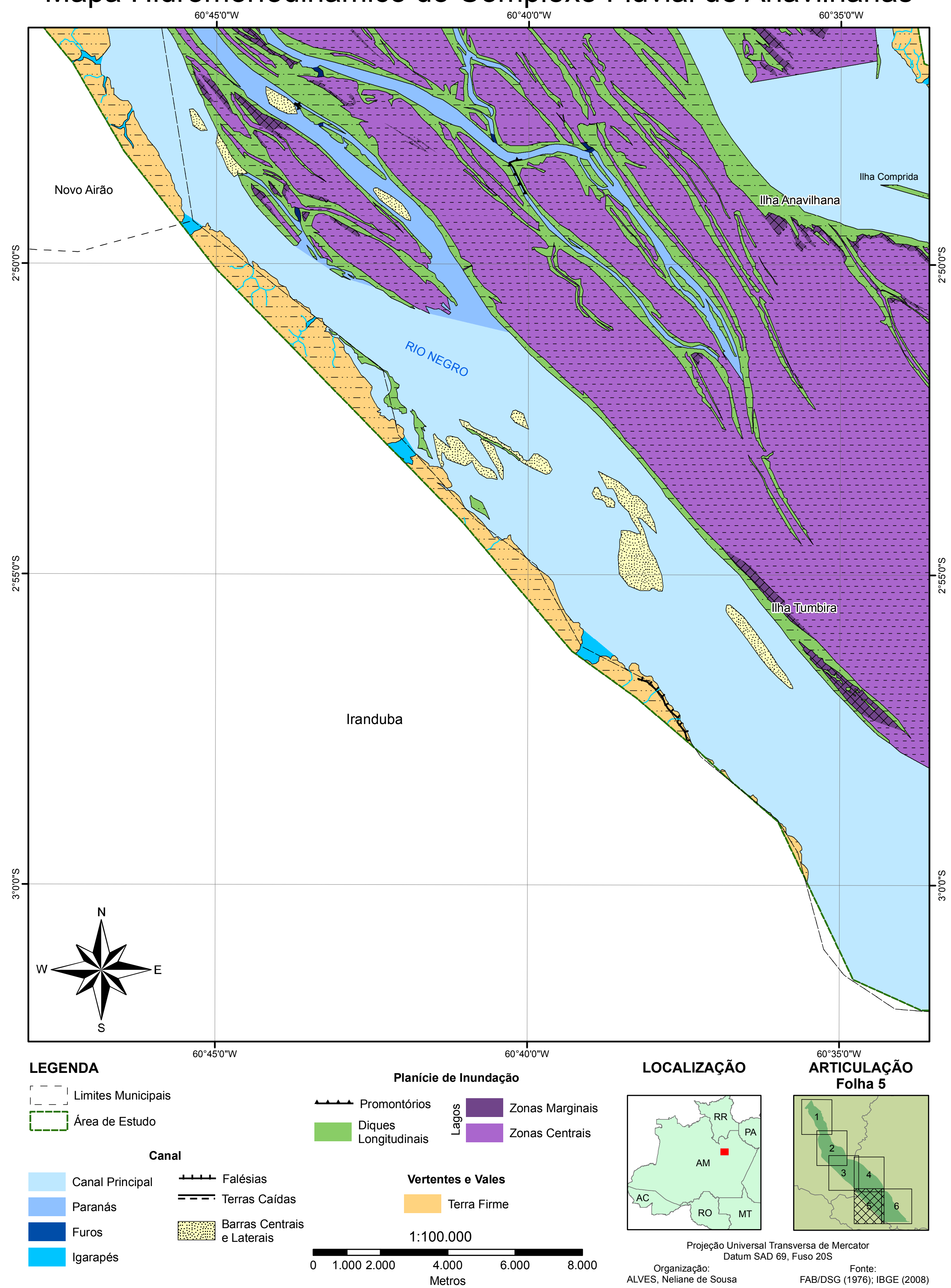




\section{Mapa Hidromorfodinâmico do Complexo Fluvial de Anavilhanas}

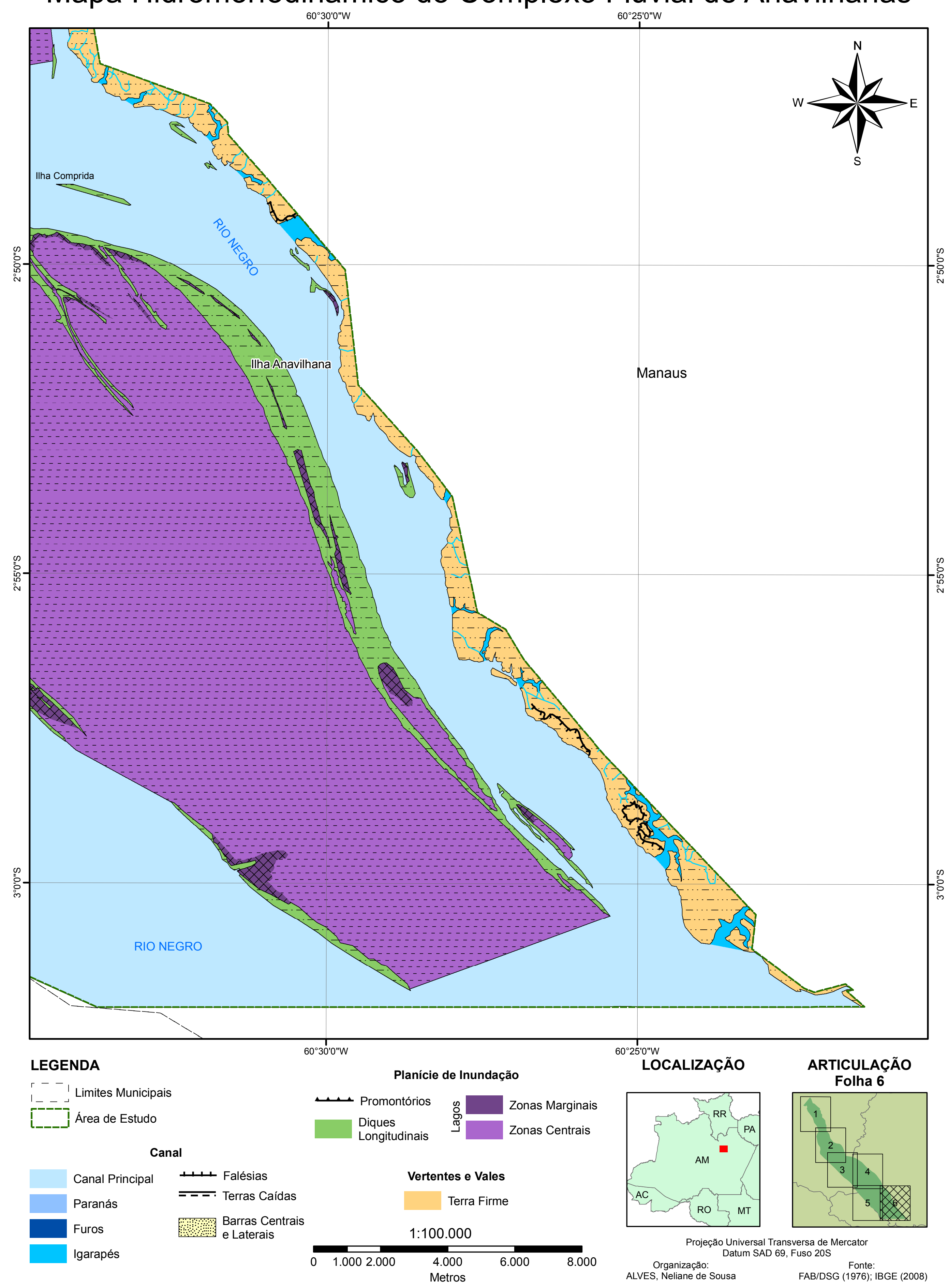


LEGENDA DO MAPA HIDROMORFODINÂMICO DO COMPLEXO FLUVIAL DE ANAVILHANAS

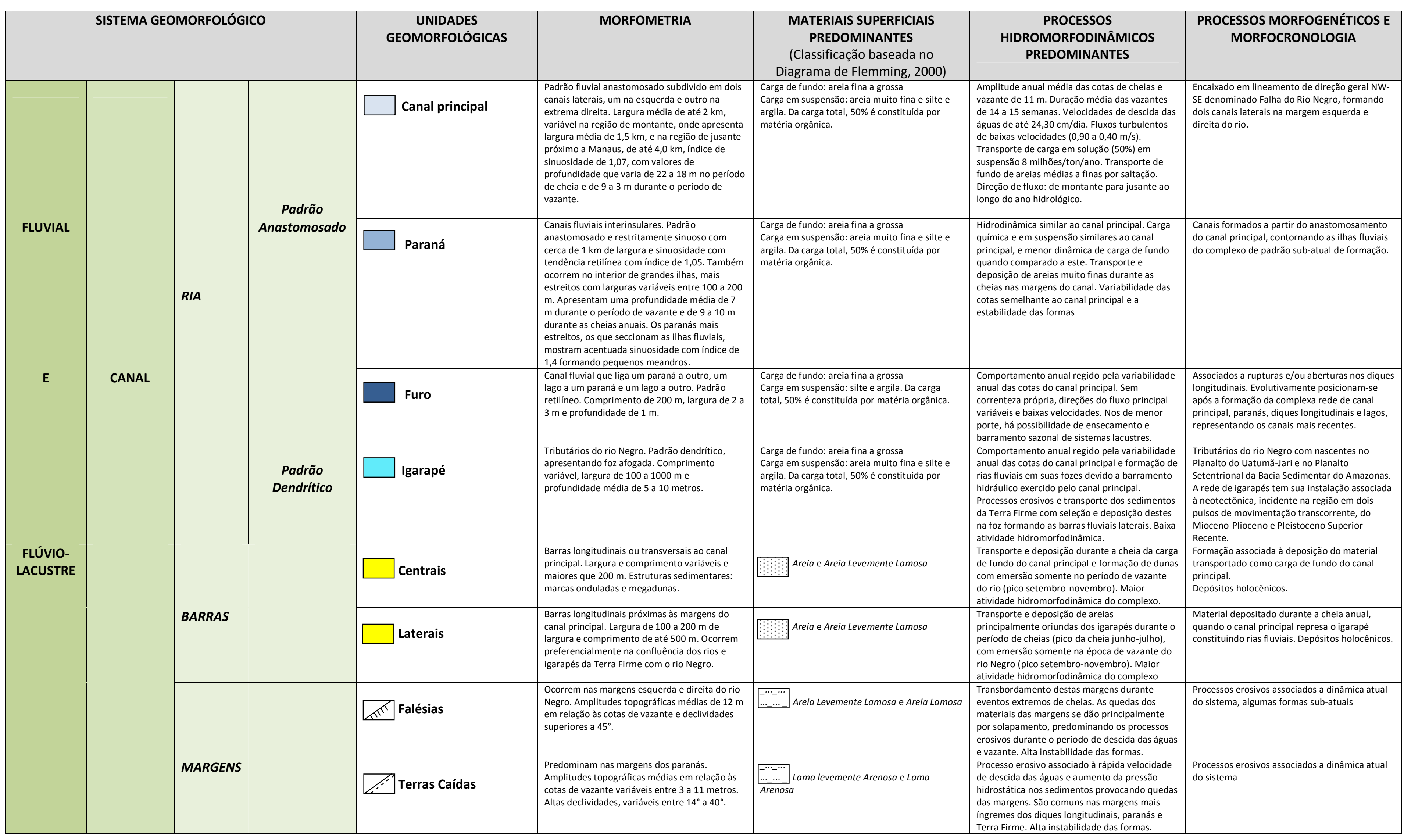


Continuação da legenda

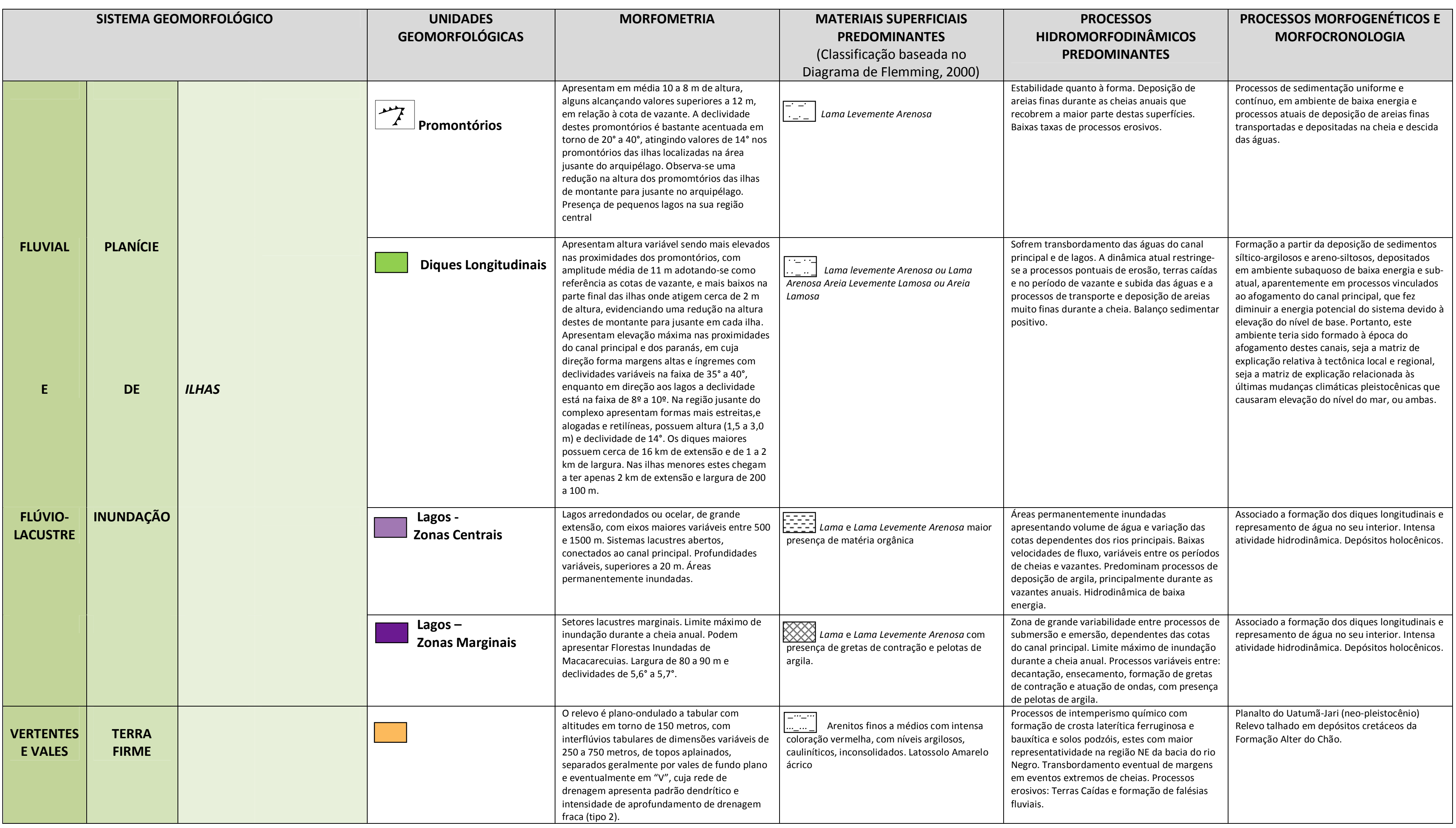




\subsection{PROCESSOS HIDROMORFODINÂMICOS E TENDÊNCIAS ESPACIAIS}

\subsubsection{Canal}

\subsubsection{Ria - Padrão Anastomosado}

\section{a) O Complexo Fluvial e o Canal Principal}

Conforme descrito anteriormente, o padrão morfológico geral do complexo, sem considerar os processos e a arquitetura deposicional, pode ser considerado como anastomosado (morfologia horizontal) ou anabranches, sendo, neste último caso, morfologicamente mais parecido com o tipo 1, ou seja, o "rios anabranches com leito de sedimentos coesos". Adota-se aqui esta classificação, ainda que se tenha recolhido uma série de evidências a respeito da dificuldade de encaixe deste nas classificações disponíveis, principalmente quando se tem a preocupação de, a partir do resultado morfológico bidimensional destes padrões, realizar interpretações sobre processos. Neste particular, além de alguns dados morfométricos não combinarem idealmente com os padrões disponíveis, eles não podem ser utilizados isoladamente para se chegar a interpretar tendência de processos atuais. A articulação entre as variáveis estudadas permitiu confirmar a relevância do reconhecimento bi e tridimensional das formas, o monitoramento hidrológico de maior acurácia espaço-temporal e o reconhecimento da arquitetura deposicional da estratigrafia para se distinguir, com maior chance de acerto, os processos e balanços atuais e os processos e balanços pré-atuais que ainda se fazem presentes na morfologia. Assim, a combinação das características morfológicas, a alta razão largura-profundidade, os grandes volumes de água transportados anualmente, a grande quantidade de carga orgânica, e a grande amplitude de variação das cotas anuais, fazem deste sistema algo único no contexto dos rios tropicais.

Neste complexo, apesar de ter sido observada uma dinâmica fluvial anual dos canais e lagos que implica em alta variabilidade anual das cotas (gradual na subida e abrupta na descida), altas vazões médias anuais dos canais, altos valores de transporte de carga orgânica anuais dos canais, os baixos valores de velocidade, os baixos gradientes do perfil longitudinal e a coesão do material síltico-argiloso dos diques acabam por definir um balanço erosivosedimentar pouco efetivo do ponto de vista das mudanças morfológicas anuais. 
Assim é possível afirmar que existem tendências deposicionais de acreção vertical com taxas anuais pouco expressivas e em locais específicos do complexo (depósitos de areias finas em partes dos diques, depósitos argilosos e argilo-orgânicos nos lagos); tendências erosivas de baixas taxas noutras morfologias específicas (margens: terras caídas, falésias; promontórios: argilas e siltes em suspensão); tendências de altas taxas de transporte de fundo nos canais principais (barras centrais e laterais/maior atividade morfodinâmica).

O somatório dessas tendências parece confirmar a hipótese de uma baixa atividade hidromorfodinâmica em contraposição a uma alta atividade hidrológica. Esta última estando associada à amplitude das cotas medidas durante as cheias e vazantes que atinge valores médios em torno de $11 \mathrm{~m}$, com longos períodos de águas altas inundando as ilhas do arquipélago por cerca de seis meses durante o ano hidrológico, impondo às comunidades vegetais e animais o desenvolvimento seletivo de espécies adaptáveis a estas variações.

As baixas velocidades registradas nas estações montante e jusante da área do arquipélago, $0,90 \mathrm{~m} / \mathrm{s}$ na estação de Serrinha e $0,40 \mathrm{~m} / \mathrm{s}$ em Paricatuba respectivamente, e a baixa carga de sedimentos transportada em suspensão também sugerem que, no rio Negro e na área de pesquisa, não são promovidos processos de erosão e de deposição de maior efetividade, sugerindo assim, um ambiente estável e de maior dinamismo quanto ao transporte de água propriamente dita e de seu material como carga química, em suspensão e de fundo, sendo este último maior responsável pelas mudanças morfológicas anuais observadas no complexo.

O rio transporta como carga de fundo, sedimentos arenosos produto da erosão das rochas mais antigas da região, e recebe dos seus afluentes uma elevada carga de sedimentos resultado do trabalho erosivo destes sobre os sedimentos cretáceos da Formação Alter do Chão.

\section{b) Paranás}

A dinâmica fluvial observada nos paranás é bastante semelhante ao rio Negro, apesar destes serem canais mais estreitos e apresentarem uma grande variabilidade de extensão e largura. O padrão anastomosado predominante, algumas vezes apresenta-se meandrante ou de 
alta sinuosidade nos paranás menores, e nestes observou-se em margens convexas, pequenos depósitos de areias muito finas transportadas durante o período de cheias e depositadas durante a descida das águas. Em eventos extremos de vazante alguns paranás são totalmente secos e exibem o leito fluvial rico em areia média a grossa. A variabilidade das cotas é a mesma referida anteriormente, assim como a estabilidade das formas de seu percurso e largura. Percebe-se uma menor dinâmica de transporte de fundo quando comparados aos ramos principais do rio Negro.

c) Furos

Os diversos furos mapeados na área do complexo apresentam o mesmo tipo de comportamento anual das cotas face às oscilações do nível do rio Negro. Não apresentam correnteza própria, sendo variável a direção do fluxo na época de cheias e de vazante (baixas velocidades de fluxo). No período de cheia, o canal principal e/ou os paranás alimentam os lagos da região através dos furos, durante a vazante, inverte-se a direção da correnteza e os lagos liberam águas para o canal principal e paranás através destes furos. Em anos de evento extremos de vazantes estes furos secam e isolam os lagos do sistema fluvial.

Não foram observadas características em sua morfologia e em seus materiais que permitissem afirmar que seu balanço erosivo-sedimentar tenha similitude aos canais principais e paranás (terras caídas e barras), exceto no que se refere à estabilidade anual de suas formas.

\subsubsection{Ria-Padrão Dendrítico}

a) Igarapés

Os igarapés, afluentes da margem esquerda e direita do rio Negro, apresentam variação anual de cotas influenciadas pela variabilidade anual do canal principal, apresentado foz afogada em sua confluência com o rio Negro constituindo rias fluviais. 
Os igarapés são responsáveis pela erosão e transporte dos sedimentos da Terra Firme (Formação Alter do Chão) em direção ao canal principal. O material transportado é depositado na sua desembocadura formando depósitos sedimentares arenosos classificados como barras fluviais laterais neste estudo.

Os levantamentos realizados também indicam para esta unidade morfológica baixa atividade hidromorfodinâmica.

\subsubsection{Barras Fluviais}

As barras fluviais centrais e laterais são formadas pela deposição de areias transportadas pelos igarapés e pelo rio Negro durante o período de cheias. Estas são totalmente submersas durante o período de cheia do rio Negro, sendo somente visíveis durante a vazante.

As barras fluviais centrais são formadas pelos sedimentos arenosos transportados como carga de fundo do rio Negro durante a cheia. No período de cheias ocorre um aumento da energia e a areia (areia muito grossa a areia fina com presença de grânulos) é transportada por mecanismo de fundo. Nas barras fluviais laterais a deposição também ocorre durante o período de cheia quando o canal principal represa o igarapé, neste caso o fluxo de água perde energia devido ao barramento do canal principal e deposita a areia na desembocadura.

As estruturas sedimentares primárias mapeadas nas barras fluviais centrais e laterais, marcas onduladas (marcas de ondas e dunas) e laminação plana, são produto de transporte e deposição de sedimentos em condições de fluxo tranquilo, condizente com velocidades de fluxo menores que $1,0 \mathrm{~m} / \mathrm{s}$.

Estas unidades morfológicas parecem ser a de maior atividade hidromorfodinâmica no complexo. 


\subsubsection{Margens}

Nas margens mapeadas na área do Complexo de Anavilhanas predominam, em comparação com processos de sedimentação, processos erosivos, regionalmente denominados de “Terras Caídas”, fenômeno comum durante o período de descida das águas e vazante.

Margens de deposição de sedimentos são restritas às de alguns paranás onde ocorre depósito de areia muito fina na base das ilhas e recobrindo os diques longitudinais de topografia mais baixa; e as áreas de confluências dos tributários do rio Negro onde são depositadas areias de granulação média a grossa.

$\mathrm{Na}$ área do complexo de Anavilhanas foram identificados vários pontos de ocorrência de terras caídas, principalmente nos diques das ilhas fluviais em seu perfil de maior declividade. Nestes locais observou-se a queda de parte destas margens, com significativas derrubadas de árvores de tamanhos diversos e material sedimentar no rio. As campanhas de campo foram realizadas em outubro de 2010, ano de vazante máxima do rio Negro na série histórica, e outubro e novembro de 2011 períodos de vazante e início de subida das águas no rio, reforçando a hipótese que este fenômeno tem como fator principal a pressão hidrostática, que é mais atuante durante a vazante.

O rio Negro tem um regime fluvial caracterizado por dois picos máximos de descarga. O período de enchente se inicia em out/novembro, com um pico no primeiro trimestre do ano, e segue até jun/julho quando normalmente ocorre o pico máximo da cheia. A partir de julho o rio começa a vazar com pico em outubro, em que chega a vazar cerca de $25 \mathrm{~cm} / \mathrm{dia}$. Logo, a velocidade de descida das águas é bem maior que a velocidade de enchente.

A tabela 13 apresenta os dados de cotas máximas e mínimas, medidas no Porto de Manaus relativo ao ano hidrológico 2010-2011 e o quanto, em metros, o rio encheu ou vazou no mesmo período. 
Tabela 13 - Processo de evolução de enchentes e vazantes referente ao ano hidrológico 2010-2011 para cotas medidas no Porto de Manaus.

\begin{tabular}{lllllll}
\hline Mês/ano & $\begin{array}{l}\text { Cota } \\
\text { Mínima } \\
(\mathbf{m})\end{array}$ & $\begin{array}{l}\text { Cota } \\
\text { Máxima } \\
(\mathbf{m})\end{array}$ & $\begin{array}{l}\text { Encheu } \\
(\mathbf{m})\end{array}$ & Vazou (m) & $\begin{array}{l}\mathbf{N}^{\circ} \text {. de Dias } \\
\text { - Enchente }\end{array}$ & $\begin{array}{l}\mathbf{N}^{\circ} \text {. de } \\
\text { Dias - } \\
\text { Vazante }\end{array}$ \\
\hline Outubro/2010 & 13,63 & 13,91 & 0,28 & 0,00 & 07 & \\
\hline Novembro/2010 & 13,97 & 16,27 & 2,36 & 0,00 & 31 & \\
\hline Dezembro/2010 & 16,41 & 18,60 & 2,27 & 0,00 & 31 & \\
\hline Janeiro/2011 & 18,62 & 20,63 & 1,95 & 0,00 & 31 & \\
\hline Fevereiro/2011 & 20,71 & 22,90 & 2,27 & 0,00 & 28 & \\
\hline Março/2011 & 23,00 & 24,89 & 1,93 & 0,00 & 31 & \\
\hline Abril/2011 & 24,94 & 26,72 & 1,83 & 0,00 & 30 & \\
\hline Maio/2011 & 26,77 & 28,26 & 1,49 & 0,00 & 31 & 31 \\
\hline Junho/2011 & 28,30 & $\mathbf{2 8 , 6 2}$ & 0,36 & $-0,01$ & 29 & 31 \\
\hline Julho/2011 & 27,57 & 28,60 & 0,00 & $-1,04$ & & 30 \\
\hline Agosto/2011 & 24,63 & 27,50 & 0,00 & $-2,94$ & & 11 \\
\hline Setembro/2011 & 17,34 & 24,45 & 0,00 & $-7,29$ & & \\
\hline Outubro/2011 & $\mathbf{1 6 , 7 6}$ & 17,87 & 1,11 & $-0,58$ & 20 & \\
\hline Fonte: Port & & & & & & \\
\hline
\end{tabular}

Fonte: Porto de Manaus, 2012

Organizado por ALVES, 2012

O rio começou a encher em outubro de 2010 e atingiu sua cota máxima de enchente em 29 de junho de 2011 de 28,62 m cujo processo demorou 249 dias; a partir daí o rio começou a vazar e atingiu sua cota máxima de vazante em 10 de outubro de 2011 de 16,76 m, vazando 11,86 m em apenas 104 dias (Tabela 14 e Figura 72).

Tabela 14 - Número de dias de enchente e vazante relativo ao ano hidrológico 2010-2011:

\begin{tabular}{ccccc}
\hline Evento & Início & Término & $\mathbf{N}^{\circ} \cdot$ de dias & Cota $(\mathbf{m})$ \\
\hline Enchente & $25 / 10 / 2010$ & $29 / 06 / 2011$ & 249 & 28,62 \\
Vazante & $30 / 06 / 2011$ & $10 / 10 / 2011$ & 104 & 16,76 \\
\hline
\end{tabular}

Fonte: Porto de Manaus, 2012

Organizado por ALVES, 2012 


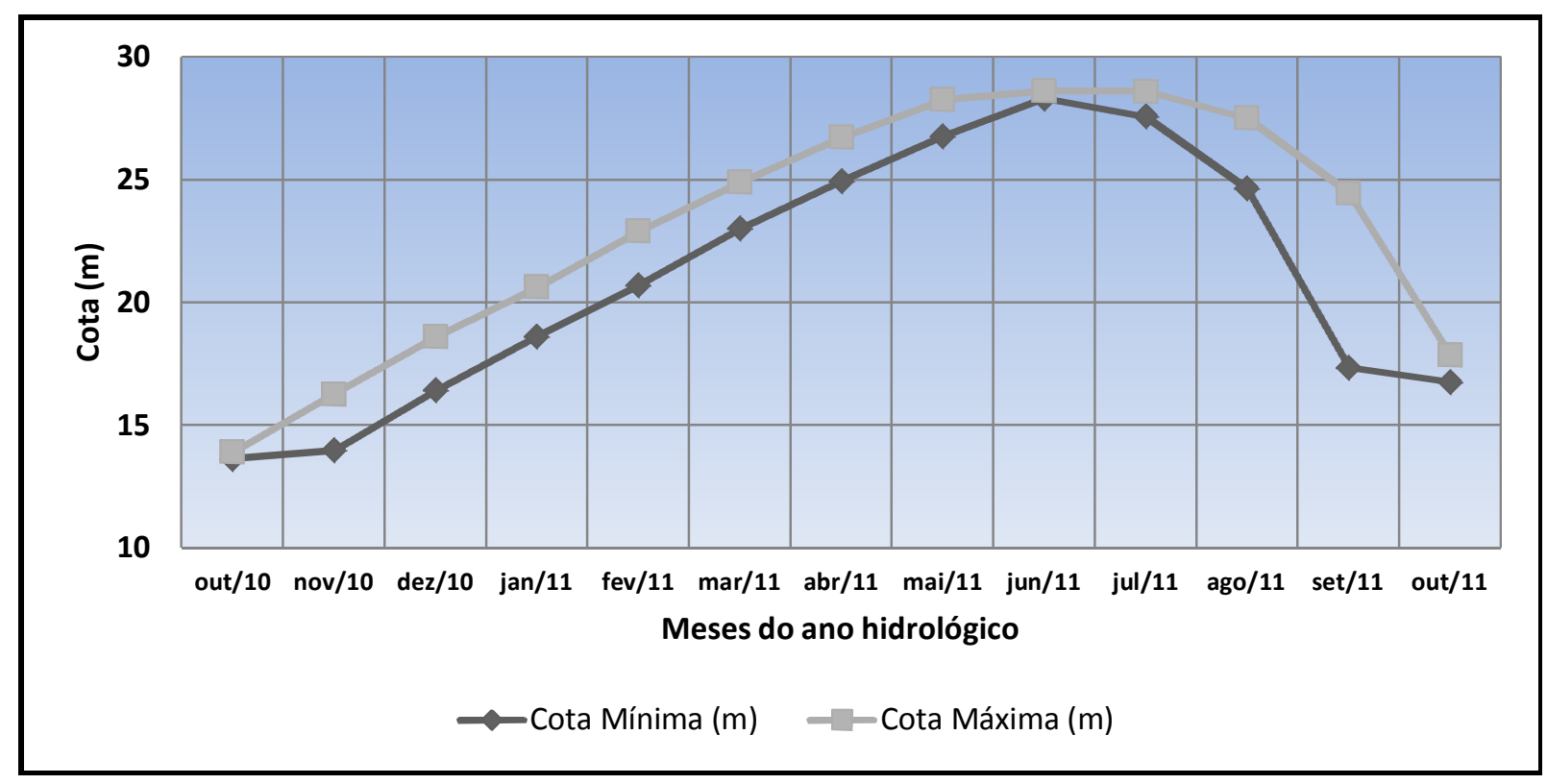

Figura 72: Cotas máximas e mínimas mensais do ano hidrológico 2010-2011.

Organização: ALVES, 2012

O processo de evolução de enchentes e vazantes no referido ano mostra que o rio Negro vazou uma média diária de 3,35 cm/dia no mês de julho, 9,48 cm/dia no mês de agosto e $24,30 \mathrm{~cm} /$ dia no mês de setembro (Figura 73 ).

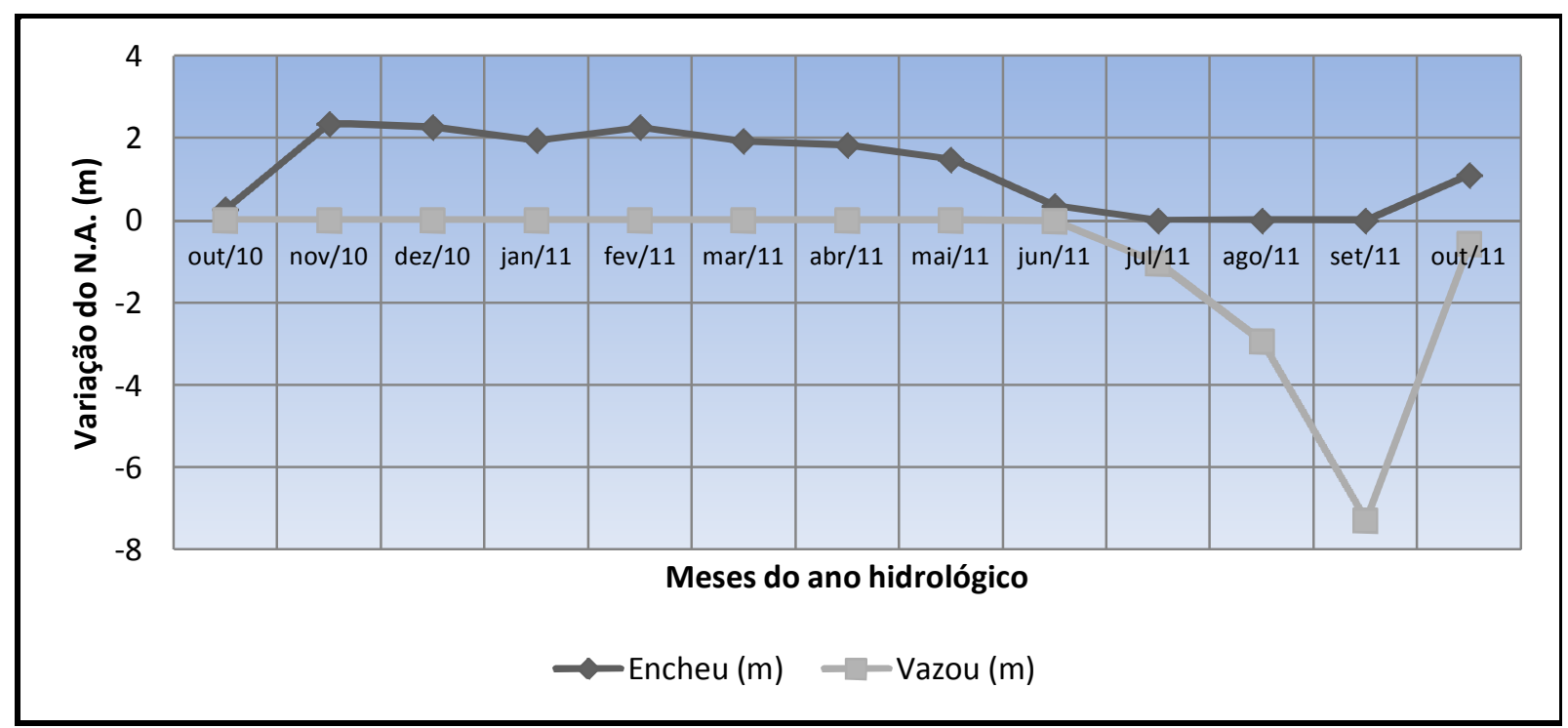

Figura 73: Variação mensal, em metros, do N.A. referente ao ano hidrológico 2010-2011. Organização: ALVES, 2012 
Durante a enchente os sedimentos síltico-argilosos das ilhas e os sedimentos argiloarenosos das margens do rio Negro ficam saturados com água devido ao longo período de subida das águas e cheia, a descida das águas do rio com velocidades diárias que chegam a atingir $25 \mathrm{~cm} /$ dia, faz com que o nível de água (nível piezométrico) nos sedimentos das ilhas e margens do rio Negro não acompanhe esta velocidade de descida, aumentando assim o peso do pacote sedimentar e a força da gravidade sobre este, aumentando a pressão hidrostática. Aliado a este fato, temos o fato de que estes materiais, com maior ou menor grau de umidade, estariam submetidos à ação de ondas no nível d'água de vazante, cujo nível é o de solapamento consequente. Isto permitiria uma maior instabilidade dos materiais acima, provocando as quedas, conforme observado na figura 74. É preciso ainda destacar o fato de que, no ano hidrológico em que o trabalho de campo foi efetuado, o fenômeno das terras caídas dos diques não se distribui de forma generalizada, ocorrendo em faixas variáveis entre dezenas a centenas de metros.

\subsubsection{Planície de Inundação}

\subsubsection{Ilhas}

\section{a) Promontórios}

Os promontórios, formas de perfil côncavo ("naval") das ilhas, apresentam evidências de estabilidade morfodinâmica atual, sendo que seus sedimentos sílticos-argilosos mostram estrutura compacta sem evidências de estratificação, indicativas de um processo de sedimentação uniforme e contínuo, típico de ambiente de baixa energia, quando da formação destes depósitos. Processos erosivos não foram identificados nestas formas. Chama à atenção a perfeita concavidade de seus perfis (forma de casco de navio) o que sugere que há alguma erosão que resultou no ajuste destas formas até produzir esta, de menor resistência à direção dos fluxos fluviais, portanto, mais estável. Há, nestes promontórios, níveis sustentados por estes sedimentos de consistência dura e por uma densa vegetação de igapó.

Estes promontórios, mesmo os de maior altitude com 11 a 12 metros, ficam totalmente submersos durante o período das cheias sendo que os de topografia mais baixa ficam submersos cerca de 6 meses durante o ano hidrológico. É durante esse período que ocorre a 
deposição de areias muito finas transportadas pelo rio Negro, processo observado nos promontórios de topografia mais baixa.
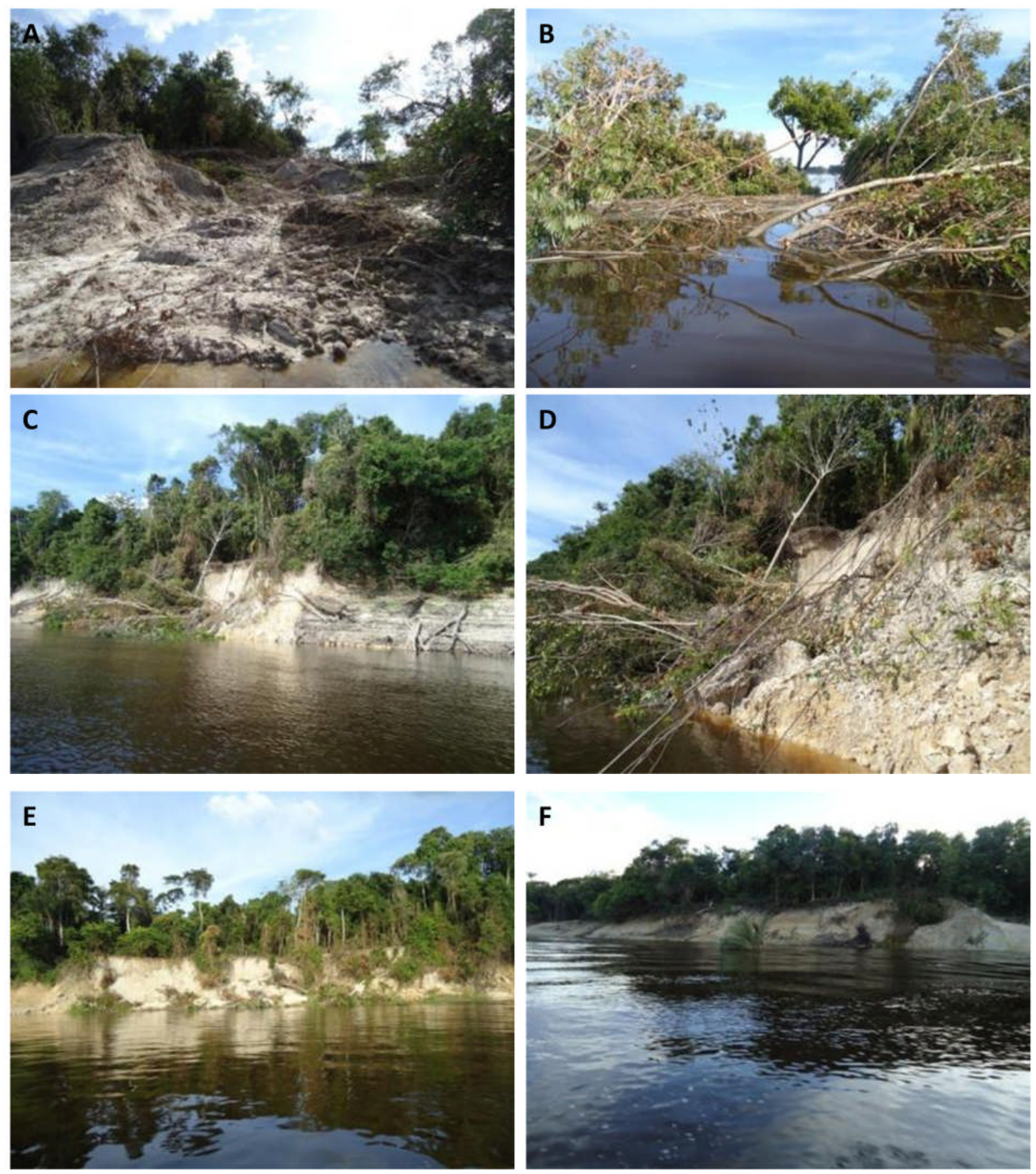

Figura 74: Terras caídas. A: Queda das margens em parte de ilha fluvial no Paraná do Sapato; B: Árvores tombadas no Paraná (mesmo local); C: Queda marginal em ilha fluvial; D: Detalhe da imagem anterior; E e F: Quedas marginais e árvores tombadas no curso d'água. (imagens da autora). 


\section{b) Diques Longitudinais}

No período de cheia anual do rio Negro as ilhas do complexo ficam totalmente submersas, por períodos de até seis meses durante o ano, ficando emersas apenas partes do estrato superior da mata de igapó. Nessa fase ocorre o transbordamento das águas dos canais fluviais e dos lagos, sobre os diques longitudinais, favorecendo a deposição de areia muito fina transportada pelo rio durante a cheia. A dinâmica atual restringe-se a processos pontuais de erosão (terras caídas) no período de vazante e subida das águas, e transporte e sedimentação de areia muito fina durante o período de cheias.

Estas evidências apontam para um balanço sedimentar positivo destes diques, no sentido da manutenção de suas funcionalidades hidrodinâmicas como diques e de sua manutenção topográfica ou até mesmo de acresção vertical, ainda que haja remanejamento e redistribuição de parte destes materiais nos setores mais superficiais. Estas tendências, assim interpretadas, poderão ser verificadas por meio de monitoramentos futuros, principalmente para se reconhecer quantitativamente os balanços erosivos $\mathrm{x}$ deposicionais e para se conhecerem as formas relictuais e as atuais. A presença destes materiais arenosos (areias finas) sobre os diques em suas porções médias e distais, com espessura variável de 0,50 a 2,00 metros, as formas destes diques com caimento gradual à jusante, a fraca ou inexistente estruturação pedológica, as inundações periódicas destes níveis são evidências de um balanço sedimentar positivo nestes setores.

A questão da origem das areias que estão sendo depositadas no topo das superfícies insulares é uma questão a ser investigada posteriormente, ou seja, identificação da área-fonte, para questões de critérios de conservação. Contudo, estudos realizados na bacia do rio Xingu (CNEC, 1987) por análise mineralógica revelaram que a área-fonte dos sedimentos arenosos das ilhas fluviais na ria localizavam-se nas próprias margens do canal, ou seja, na Formação Alter do Chão.

Do ponto de vista de sua morfogênese, concorda-se com parte das afirmações de autores como Tricart (1977a), Silva, C. L. (2005), Silva, C. L. et al. (2007), Silva, C. L. e Rossetti (2009), e Latrubesse e Franzinelli (2005). A formação destes diques longitudinais, de formas alongadas estaria ligada, principalmente, aos materiais subjacentes a estas areias, materiais estes constituídos por sedimentos síltico-argilosos e areno-siltosos, depositados em ambiente subaquoso de baixa energia e sub-atual, aparentemente em processos vinculados ao 
afogamento deste canal, que fez diminuir a energia potencial do sistema devido à elevação do nível de base. Portanto, este ambiente teria sido formado à época do afogamento destes canais, seja a matriz de explicação relativa à tectônica local e regional, seja a matriz de explicação relacionada às últimas mudanças climáticas pleistocênicas que causaram elevação do nível do mar, ou ambas.

Neste sentido, é importante colocar que existem variáveis de grande escala, às quais a bacia estaria vinculada durante estes períodos, dentre as quais há que se considerar o próprio balanço hidromorfodinâmico da bacia amazônica até o ponto do encontro das águas.

A matriz explicativa da floculação necessitaria de maiores investigações para serem consideradas, principalmente do ponto de vista de dados reológicos das principais frações granulométricas presentes nestes materiais subjacentes que apontam para ambiente duradouro de sedimentação, sub-aquoso e de baixa energia.

\section{c) Lagos - zonas centrais e marginais}

Conforme dito anteriormente, os lagos na área do Complexo de Anavilhanas apresentam formas (lagos redondos, lagos compridos) e tamanhos variados (pequenos, médios e grande lagos com áreas de até $75 \mathrm{~km}^{2}$ ), cujo volume de água e velocidade de fluxo está sujeita a variabilidade anual do N.A. do canal principal e paranás e a quantidade de águas de transbordamento. Predomina no complexo o isolamento destes lagos durante o período de vazante, com conexão ao canal fluvial apenas durante o período das cheias. Na cheia as águas da maioria dos lagos unem-se as águas do canal principal formando um único canal, ficando apenas parcialmente isolados os lagos no interior de ilhas cujos diques longitudinais são de topografia mais elevada. Os lagos compridos, localizados à jusante na área do complexo, comunicam-se permanentemente com o rio, de forma que as oscilações do N.A. dos lagos é a mesma observada no rio Negro.

Para a tipologia de lagos isolados Jardim-Lima et al. (2005) verificaram que na bacia Amazônica a morfologia dos lagos, redondos ou compridos, parece influenciar diferentemente na extensão da área de inundação para o pulso de inundação (amplitude) de $11 \mathrm{~m}$ que caracteriza a região. De acordo com os autores, os lagos redondos apresentam área de inundação relativamente maior que os lagos compridos, em função das características 
geomorfológicas desses corpos de água. Provavelmente lagos de forma comprida têm seus níveis de água fortemente influenciados pela velocidade de corrente que, nessa tipologia, tende a ser mais direcional, isto é, com maior característica de transporte do que de acumulação.

Durante o período de vazante a maioria dos lagos, em Anavilhanas, fica isolada do canal principal e este isolamento associado à redução da velocidade de fluxo favorecem processos de deposição do material mais fino (silte e argila) transportado em suspensão pelo rio Negro durante o período de cheia, configurando um balanço sedimentar positivo de acresção vertical desses finos. Os sedimentos presentes são classificados como Lama (silte + argila), configurando um ambiente lacustre cuja hidrodinâmica é de muito baixa energia, favorecendo, do ponto de vista mecânico, a decantação. Nos grandes lagos isolados, que apresentam velocidades maiores, ocorre, além da deposição da argila com estruturas de gretas de contração, a deposição de grande quantidade de "pelotas" de argila selecionadas pela energia das pequenas ondas que se formam nas margens destes lagos.

\subsubsection{Terra Firme}

A margem do canal principal, na Terra Firme, caracteriza-se pela formação de falésias fluviais. Estas se formam também na foz dos tributários do rio Negro e atingem cerca de 12 metros de altura. Em eventos extremos de cheia, a exemplo de 2012, ocorre o transbordamento destas margens estando estas também sujeitas à variabilidade anual das cotas do rio Negro.

Predominam, na Terra Firme, processos erosivos dos sedimentos cretáceos da Formação Alter do Chão com o solapamento de suas margens, ou terras caídas. A ocorrência espacial desse fenômeno é restrita a alguns trechos da margem do canal e os processos atuantes semelhantes aos que ocorrem nas margens dos diques longitudinais conforme explicado anteriormente. $\mathrm{O}$ material erodido na vertente e vales é transportado pelos igarapés e depositados na desembocadura destes com o canal principal formando as barras fluviais laterais. 


\section{CONSIDERAÇõES FINAIS}

A pesquisa desenvolvida objetivou caracterizar as tendências espaciais de processos hidromorfodinâmicos no Complexo Fluvial de Anavilhanas e a produção de sua cartografia na escala 1:100.000. Somam-se a este conhecimento a produção de contribuições efetivas para o manejo e gestão da Unidade de Conservação - Parque Nacional de Anavilhanas, numa perspectiva de conservação e preservação ambiental dos rios amazônicos e sua geodiversidade.

O mapeamento hidromorfodinâmico realizado teve como base a abordagem sistêmica, cuja metodologia adotada permite afirmar que estudos tradicionais de Geomorfologia, aí incluídos os de cartografia geomorfológica de detalhe e de semi-detalhe podem ser aplicados aos grandes sistemas fluviais amazônicos na descoberta de tendências espaciais de processos e na articulação dos levantamentos, permitindo tecer hipóteses a respeito da morfogênese desses sistemas e das relações entre estes, enquanto sistemas Amazônicos.

O uso da Cartografia Geomorfológica como ferramenta articuladora dos diversos campos do conhecimento correlacionados tanto no nível descritivo quanto interpretativo, contribuiu para integralizar e hierarquizar as informações e diversas variáveis disponíveis, na estrutura do sistema, produzindo-se a Carta Geomorfológica de Detalhe da área do Complexo Fluvial de Anavilhanas, na escala 1:100.000, que atendeu as expectativas e mostrou-se eficiente do ponto de vista da escala de mapeamento e discernimento das unidades morfológicas mapeadas.

Por meio da Cartografia Geomorfológica detalhada em 1:100 000, levantamentos morfológicos de campo e análises sedimentológicas foram caracterizados na área do Complexo de Anavilhanas, três sistemas hidromorfodinâmicos distintos: Canal, Planície de Inundação e Terra Firme. Os processos típicos destes três compartimentos apresentam comportamentos sazonais distintos em períodos de vazante, na subida das águas e nas cheias, todos comandados pelo efeito de barramento hidráulico causado pela variação anual dos níveis d'água do rio Solimões. Este efeito de barramento hidráulico do rio Solimões sobre o rio Negro é bastante intenso e pode ser observado da foz até a sua confluência com o rio Branco. 
Quanto à morfogênese do Arquipélago de Anavilhanas existem diversos estudos e modelos propostos para a formação deste. A maioria dos estudos atribui à tectônica regional sua formação (Tricart, 1977a; Projeto RADAM, 1978; Almeida Filho, Miranda e Beisl, 2005; Latrubesse e Franzinelli, 2005; Silva, 2005; Silva et al., 2007; Silva e Rossetti, 2009). Os estudos de Leenheer e Santos (1980) são fundamentados em processos de sedimentação. Tricart (1977a) considera que o trecho anastomosado do rio Negro (Arquipélago de Anavilhanas) seria um delta; o Projeto RADAM (1978) sugere que neste trecho o rio Negro está adaptado a uma estrutura do tipo rift-valley; Almeida Filho, Miranda e Beisl (2005) sugerem que o traçado atual do rio Negro na região de Anavilhanas resultaria de uma mega captura fluvial; Latrubesse e Franzinelli (2005); Silva (2005); Silva et al. (2007); Silva e Rossetti (2009) sugerem que o Complexo de Anavilhanas é resultado de processos de sedimentação, em ambiente de baixa energia, associado à tectônica local; enquanto Leenheer e Santos (1980) atribuem a formação das ilhas de Anavilhanas a floculação (pelas águas do rio Negro) dos sedimentos finos oriundos do rio Branco, hipótese descartada neste estudo, visto que deveriam ser consideradas maiores investigações principalmente do ponto de vista de dados reológicos das principais frações granulométricas presentes nos materiais subjacentes que apontam para ambiente duradouro de sedimentação, sub-aquoso e de baixa energia.

A proposta apresentada neste estudo contempla, para a morfogênese do Complexo de Anavilhanas, a articulação de diversos processos geológicos-geomorfológicos incluindo a tectônica, processos sedimentológicos (erosão, transporte e deposição), hidrológicos e ecológicos. Fatores como a estrutura tectônica regional onde o rio Negro está encaixado em lineamento estrutural - Falha do Rio Negro de direção NW-SE, a ocorrência de falésias em suas margens relacionadas ao afogamento dos canais, o controle estrutural dos seus tributários e a presença de foz afogada nestes, constituindo rias fluviais, corroboram com um modelo morfogenético fortemente influenciado pela tectônica. Associadamente à tectônica somam-se fatores ambientais mais gerais, eventualmente ligados a mudanças climáticas ou a mudanças no desenvolvimento dos próprios sistemas deposicionais. Tais fatores encontram respaldo nas características sedimentológicas identificadas, como o predomínio de sedimentos sílticosargilos nas ilhas (promontórios e diques) do complexo associadamente à ausência de estruturas sedimentares e a transições abruptas entre os pacotes sedimentares que os sustentam. Essas características indicam processo de sedimentação uniforme em ambiente de baixa energia para ambos os pacotes sedimentares, restando revelar a que sistemas ou 
subsistemas deposicionais fluviais e flúvio lacustres eles pertenceriam. Para isto, recomendase, por exemplo, maior acurácia espacial quanto às descrições estratigráficas, mineralógicas, estruturais e da arquitetura deposicional destes pacotes. As baixas velocidades das águas inferidas para estes ambientes de sedimentação e a redução destas na proximidade da confluência com o rio Solimões pelo efeito de barramento hidráulico que aumentou o nível de base local, favoreceram processos de sedimentação no canal, em ambiente subaquoso de baixa energia. Este ambiente de sedimentação pré-atual teria sido formado à época do afogamento destes canais, seja a matriz de explicação relativa à tectônica local e regional, seja a matriz de explicação relacionada às últimas mudanças climáticas pleistocênicas que causaram elevação do nível do mar, ou ambas.

Os dados hidrológicos analisados mostram que, apesar das vazões elevadas, as velocidades médias não ultrapassam $1 \mathrm{~m} / \mathrm{s}$, atingindo valores médios de $0,40 \mathrm{~m} / \mathrm{s}$ em Paricatuba. No período de cheias o rio atinge velocidades de até $0,65 \mathrm{~m} / \mathrm{s}$ possibilitando o transporte de areias muito finas em suspensão, que são depositadas durante a descida das águas. O uso do diagrama de Hjulstrom e as análises acima contribuem para a tese de que na área do complexo predominam, de forma geral na planície de inundação e principalmente nos diques e lagos, baixas taxas de erosão e sedimentação. Processos erosivos demandariam velocidades de fluxo maiores, e, para a deposição de finos (silte e argila), seriam necessárias velocidades extremamente baixas, a exemplo do que é observado no ambiente lacustre.

A análise da série histórica (1902-2012) de cotas medidas no porto de Manaus mostrou que os eventos de cheias extremas na bacia do Rio Negro diminuíram em tempo de recorrência e ampliaram sua intensidade, de maneira semelhante a diversas seções da bacia Amazônica onde um aumento de eventos extremos tem sido registrado em menores intervalos de tempo, associados à intensificação dos fenômenos de vazante ou de enchente. Os fenômenos oceânico-atmosféricos El Niño e La Niña são apontados como responsáveis por estes eventos extremos na região amazônica, afetando as inundações e processos de sedimentação, e possivelmente a morfologia dos rios amazônicos, fato a ser considerado em trabalhos futuros na região.

As unidades morfológicas, fluvial e flúvio-lacustre, mapeadas no Complexo de Anavilhanas incluem os sistemas canal, planície de inundação e terra firme. O sistema canal 
(ria - padrão anastomosado) compreende o canal principal (rio Negro), os paranás e os diversos furos mapeados.

Se tomarmos como recurso a morfologia em planta, o complexo de Anavilhanas apresentaria o padrão anastomosado. Ao serem descritos outros parâmetros, mais relacionados a processos e ao papel da planície de inundação, o complexo pode ser considerado como padrão anabranches do tipo 1 de acordo com a classificação de Nanson e Knighton (1996). Esta classificação foi adotada apesar das dificuldades de encaixe do padrão de canal nas classificações disponíveis, pois alguns dados morfométricos não combinam idealmente com estas classificações, a exemplo da razão largura/profundidade do canal que na área do complexo é bastante alta. Tal fato, associado à combinação das características morfológicas, aos grandes volumes de águas transportados anualmente, à grande quantidade de carga orgânica e à grande amplitude de variação das cotas anuais, fazem deste, um sistema único no contexto dos rios tropicais. Nos canais principais a dinâmica fluvial apresenta alta magnitude a exemplo da amplitude das cotas medidas durante as cheias e vazantes que é de 11 metros, das altas vazões médias anuais, dos altos valores de transporte de carga orgânica anuais e da alta taxa de transporte de carga de fundo. As baixas velocidades, a estabilidade das formas e a baixa carga de sedimentos transportada em suspensão sugerem que este rio, na área de pesquisa, não promove processos de erosão e de deposição efetivos, indicando assim, em termos de processos morfodinâmicos, um ambiente estável.

Os paranás constituem os canais fluviais localizados entre as ilhas e no interior destas, cuja dinâmica fluvial é bastante semelhante ao canal principal. Apresentam padrão de canal anastomosado e localmente meandrante exibindo leitos arenosos em períodos de vazante extrema. Os furos, canais de menor dimensão, estão mais sujeitos a dinâmica fluvial do canal principal visto que não possuem correnteza própria e servem como canais de conexão entre os lagos e o canal principal, ou entre paranás e entre lagos e paranás.

O sistema canal (ria-padrão dentrítico) compreende os igarapés cursos d'água tributários do rio Negro, que apresentam um forte controle estrutural e apresentam fozes afogadas, constituindo rias fluviais, formadas devido ao barramento hidráulico exercido sobre estes pelo rio Negro. Estes igarapés transportam material como carga de fundo para o canal principal e os depositam na sua desembocadura devido a este barramento hidráulico formando 
barras fluviais laterais. A dinâmica fluvial destes canais também se caracteriza pela variação anual de cotas influenciadas pela variabilidade anual do canal principal,

Ainda contemplando o sistema de canal foram mapeadas barras fluviais centrais e laterais e individualizadas dois tipos de margens de canal, falésias e terras caídas. As barras fluviais centrais e laterais configuram-se como as formas de maior atividade morfodinâmica, principalmente para os processos de transporte. São somente expostas durante o período de vazante e são constituídas por areias médias a finas, exibindo estruturas sedimentares como marcas de ondas e dunas. O tipo de material depositado, as estruturas sedimentares associadas e a baixa velocidade do canal indicam condições de transporte e deposição sob fluxo tranquilo.

As margens de canal apresentam grande estabilidade em alguns setores, como nos promontórios, mas podem apresentar o fenômeno das terras caídas em determinados trechos no período de descida das águas e vazante. A ocorrência de terras caídas é apontada neste estudo como resultado da descida rápida das águas durante a vazante, com velocidades de até $25 \mathrm{~cm} /$ dia, e a ação da pressão hidrostática sobre os sedimentos provocando queda das margens. Associam-se a estes processos erosivos a formação das falésias fluviais as margens do rio Negro, na Terra Firme.

A planície de inundação corresponde às ilhas fluviais e contempla a região de promontórios, localizados na parte frontal destas, os diques longitudinais e os lagos localizados no seu interior. Estas ilhas fluviais são constituídas por material síltico-argiloso e mostram forte estabilidade quanto às formas e dinâmica fluvial sazonal relacionada a amplitude da inundação anual do sistema fluvial. Os promontórios correspondem à porção mais elevada das ilhas e os diques longitudinais possuem topografia mais baixa em relação a estes e são palco de processos erosivos, terras caídas, em suas margens mais íngremes e processos de deposição de areias muito finas depositas pelo rio durante o período de cheias e descida das águas, evidenciando uma descontinuidade entre o balanço deposicional nas partes mais altas e mais baixas das ilhas. Os lagos apresentam tamanho e morfologia variada e dinâmica flúvio-lacustre sazonal, alternando hidrodinâmica lacustre de baixa energia ou aumento da energia de fluxo com a elevação dos níveis d'água e conexão com a dinâmica dos canais fluviais. 
As morfologias de vertentes e vales mapeadas correspondem ao ambiente de Terra Firme cujo relevo foi esculpido nos sedimentos cretáceos da Formação Alter do Chão. Predominam aqui processos erosivos, terras caídas, produzindo o solapamento das margens do canal e a presença de falésias fluviais.

A pesquisa realizada foi baseada na abordagem sistêmica e produziu, a partir desta abordagem e da pesquisa geomorfológica, subsídios para afirmar que na área do Complexo de Anavilhanas a dinâmica sazonal dos processos de cheias, inundações e vazantes, apesar de apresentar alta magnitude do ponto de vista hidrológico e do volume total de material mobilizado, confere à morfologia do complexo uma estabilidade significativa e que a tendência evolutiva de seu balanço morfogenético holocênico parece estar ligada a uma ligeira degradação/erosão de seus trechos de jusante, confirmando assim a hipótese ventilada para a hidromorfodinâmica atual da área.

A pesquisa também demostrou que a preservação e a conservação da UC Parque Nacional de Anavilhanas são dependentes não só da conservação da bacia do rio Negro como também da quase totalidade da bacia Amazônica, tendo em vista a comprovada influência do sistema Solimões-Amazonas para com o comportamento das cotas fluviais do rio Negro para além de 100 km de distância à montante do encontro das águas. 


\section{REFERÊNCIAS BIBLIOGRÁFICAS}

AB'SABER, A. N. Bases para o estudo dos ecossistemas da Amazônia brasileira. Estudos Avançados 16 (45), 2002.

AB'SABER, A. N. Os domínios de Natureza no Brasil: Potencialidades Paisagísticas. Ateliê Editorial: São Paulo, SP. 2003.

AB'SABER, A. N. Problemas da Amazônia brasileira. Estudos Avançados. 19 (53), 2005.

ALlARD, T.; MENGUY, N., SALOMON, J.; CALLIGARO, T.; WEBER, T.; CALAS, G.; BENEDETTI, M. Revealing forms of iron in river-borne material from major tropical rivers of the Amazon Basin (Brazil). Geochimica et Cosmochimica Acta 68 (14), 3079-3094, 2004.

ALLARD, T.; WEBER, T.; BELLOT, C.; DAMBLANS, C.; BARDY, M.; BUENO, G.; NASCIMENTO, N. R. Tracing source and evolution of suspended particles in the Rio Negro Basin (Brazil) using chemical species of iron. Chemical Geology 280: 79-88, 2011.

ALMEIDA FILHO, R.; MIRANDA, F. P.; BEISL, C. H. Evidência de uma mega captura fluvial no rio Negro (Amazônia) revelada em modelo de elevação digital da SRTM. In: Anais do Simpósio Brasileiro de Sensoriamento Remoto, XII, Goiânia, GO, p.1701-1707, 2005.

AMSLER, M., PRENDES, H. Transporte de sedimentos y procesos fluviales asociados. In: PAOLI, C., SCHREIDER, M. (eds.) EI Río Paraná en su tramo medio. Centro de Publicacions Universitarias, Universidad Nacional del Litoral, Santa Fe, Argentina, 233-306, 2000.

ANA - Agência Nacional de Águas - Sistema Nacional de Informações sobre Recursos Hídricos - SNIRH. Disponível em http://www.portalsnirh.ana.gov.br

AYOADE, J. O. Introdução à climatologia para os Trópicos. $4^{\mathrm{a}}$ Ed. São Paulo: Bertrand Brasil, 1996.

ANDRADE C. A. C.; CUNHA F. M. B. Geologia da Bacia Paleozóica do Amazonas. In: Anais ...25 Congresso Brasileiro de Geologia, São Paulo SBG 3: 93-112, 1971.

BAKER, V. Adjustment of fluvial systems to climate and source terrain in tropical and subtropical environments. In: MIALL, A.D. (ed.) Fluvial Sedimentology, Memoir-Canadian Society of Petroleum Geologists, v. 5, p.211-230, 1978.

BERTRAND, G. Paisagem e Geografia Física global: esboço metodológico. São Paulo, Instituto de Geografia, USP. Cadernos de Ciências da Terra, 13, 27p. 1972.

BIGARELLA, J. J. Estrutura e Origem das Paisagens tropicais e subtropicais. Vol.3. Florianópolis: EDUFSC, 2003.

BRASIL. LEI N ${ }^{\circ} 9.985$ de 18 de junho de 2000. Institui o Sistema Nacional de Unidades de Conservação (SNUC). Diário Oficial da República Federativa do Brasil, Poder Executivo, 
Brasília, DF. Disponível em: http://www.planalto.gov.br/ccivil/leis/L9985.htm. Acesso em jun.2010.

BRASIL. LEI N ${ }^{\circ} 11.799$ de 29 de outubro de 2009. Transforma a Estação Ecológica de Anavilhanas, criada pelo Decreto n⿳0 86.061, de 2 de junho de 1981, em Parque Nacional de Anavilhanas.Diário Oficial da República Federativa do Brasil, Poder Executivo, Brasília, DF. Disponível em: http://www.planalto.gov.br/ccivil_03/_Ato20072010/2008/Lei/L11799.htm. Acesso em jun.2010.

BRASIL. Ministério do Meio Ambiente. Instituto Chico Mendes de Biodiversidade ICMBio. Parque Nacional de Anavilhanas. Disponível em: http://www.icmbio.gov.br/portal/o-que-fazemos/visitacao/ucs-abertas-a-visitacao/212-parquenacional-anavilhanas.html. Acesso em abril 2011.

BRIDGE, J. S. The interaction between channel geometry, water flow, sediment transport and deposition in braided rivers. In: BEST, J. L.; BRISTOW, C. S. (eds), Braided rivers. Special Publications of the Geological Society of Londom 75, 13-71, 1993.

CAPRA, F. A Teia da Vida. São Paulo: Cultrix, 1996.

CAPUTO, M. V. Stratigraphy, Tectonics, Paleoclimatology and Paleogeography of Northen Basins of Brazil. Tese de Doutorado, University of California, Santa Barbara, USA. 566p. 1984.

CAPUTO, M. V.; ANDRADE, F. G. Geologia em semidetalhe do flanco sul da bacia Amazônica entre os rios Cupari e Abacaxis. PETROBRÁS, Relatório Interno 589. 1968.

CAPUTO, M. V.; CROWELL, J. C. Migration of Glacial Centers across Gondwana during Paleozoic Era. Geol. Soc. Am. Bull., 96 (8), p. 1020-1036, 1985.

CAPUTO, M. V.; RODRIGUES, R.; VASCONCELOS, D. N. Litoestratigrafia da Bacia do Amazonas. Brasil: PETROBRAS/RENOR, 92p, 1971.

CAPUTO, M. V.; RODRIGUES, R.; VASCONCELOS, D. N. Nomenclatura estratigráfica da bacia do Amazonas: histórico e atualização. In: $26^{\circ}$ Congresso Brasileiro de Geologia, Belém. Anais... SBG, v. 3, p. 35-46. 1972.

CAPUTO, M. V.; SAD, A. R. E. Geologia do Baixo rio Negro e trecho da BR-174. PETROBRÁS, Belém, Sistema de Informação de Exploração 130-5170 (Relatório Interno). 1974.

CARVAlHO, B. S.; ALVES, N. S. Análise do regime pluviométrico da Bacia Hidrográfica do Rio Negro no período de 1992-2011. Artigo aceito no XV Simpósio Brasileiro de Geografia Física. Vitória, ES (no prelo), 2013.

CARVAlHO, J. A. L. Terras Caídas e Conseqüências Sociais: Costa do Miracauera -

Paraná da Trindade, Município de Itacoatiara-AM, Brasil. Dissertação de Mestrado. Programa de Pós-Graduação Sociedade e Cultura na Amazônia. Instituto de Ciências Humanas e Letras-ICHL/UFAM. 141p, 2006. 
CHRISTOFOLETTI, A. Análise de Sistemas em Geografia. São Paulo: HUCITEC: Ed. Da Universidade de São Paulo, 1979.

CHRISTOFOLETTI, A. Geomorfologia. São Paulo: Edgard Blucher, 1980.

CHRISTOFOLETTI, A. Geomorfologia Fluvial. São Paulo: Edgard Blucher, 1981.

CHORLEY, R. J.; KENNEDY, B.A. Physical Geography: a Sistems Aproach. Prentice Hall Inc. Co., Londres, 370p. 1971.

CHURCH, M. Pattern os instability in a wandering gravel bed channel. In: COLLINSON, J. D.; LEWIS, J. (Eds). Modern and ancient fluvial systems. Oxford: Blackwell, Special Publication of the International Association of Sedimentologists 6, 169-180, 1983.

COLTRINARI, L. Contribuição à Geomorfologia da Região de Guaratinguetá Aparecida. Tese de doutorado. Departamento de Geografia FFLCH/USP, 1975.

COLTRINARI, L. Um exemplo de carta geomorfológica de detalhe: a carta do Médio Vale do Rio Parateí, SP (1:25.000). In: Revista do Departamento de Geografia, USP-FFLCH, n.1, p. 55-61, São Paulo, 1982.

COLTRINARI, L. Cartas Geomorfológicas. In: Orientação, 5. Instituto de Geografia USP. São Paulo, 1984.

CORDANI, U. B.; BRITO NEVE S, B. B.; FUCK, R. A.; THOMAZ FILHO, A.; CUNHA, F. M. B. Estudo preliminar de integração do pré-cambriano com os eventos tectônicos das bacias sedimentares brasileiras. Ciências Técnica Petróleo. Petrobrás. Centro de Pesquisas e desenvolvimento Leopoldo A. Miguez de Mello. Seção Exploração de Petróleo, n. 15, 70p 1984.

COSTA, M. L. Aspectos geológicos dos lateritos da Amazônia. Revista Brasileira de Geociências, v. 21, n. 2, p. 146-60, 1991.

COSTA, J. B. S.; BEMERGUY, R. L.; HASUI, Y.; BORGES, M. S.; FERREIRA JUNIOR, C. R. P.; BEZERRA, P. E. L.; COSTA, M. L.; FERNANDES. J. M. G. Neotectônica da Região Amazônica: Aspectos tectônicos, geomorfológicos e deposicionais. Geonomos, 4 (2), p.23-44, 2008.

CPRM - Companhia de Pesquisa e Recursos Minerais. Boletim n ${ }^{\circ} 21$ de 22/06/2011. Disponível em: http://www.cprm.gov.br/rehi/manaus/pdf/alerta21_11.pdf. Acesso em julho/2011.

CPRM - Companhia de Pesquisa e Recursos Minerais. Geologia e Recursos minerais do Estado do Amazonas. Programa Geologia do Brasil, Integração, Atualização e Difusão de Dados da Geologia do Brasil. Mapas Geológicos Estaduais. Escala: 1:1.000.000. 2006.

CPRM - Companhia de Pesquisa e Recursos Minerais. Monitoramento Hidrológico das Bacias dos Rios Negro, Solimões e Madeira. Disponível em: www.cprm.gov.br. Acesso em julho/2011. 
CRUZ, N. M. C. Quitinozoários da Bacia do Solimões, Brasil. Belém, 1987. Relatório Interno. In: EIRAS, J. F.; BECKER, C. R., SOUZA, E. M.; GONZAGA, F. G.; SILVA, J. G. F.; DANIEL, L. M. F.; MATSUDA, N. S.; FEIJÓ, F. J. Bacia do Solimões. Boletim de Geociências da Petrobrás, v. 8, n. 1, p. 17-45, 1994.

CUNHA, E. da. Amazônia - um paraíso perdido. Manaus: Editora Valer; Governo do Estado do Amazonas; EDUA (Coleção Poranduba), 2003.

CUNHA, P. R. C., GONZAGA, F. G., COUTINHO, L. F. C., FEIJÓ, F. J. Bacia do Amazonas. Boletim de Geociências da Petrobrás, v. 8, n.01, p. 47-55, 1994.

DAEMON, R. F. Contribuição à datação da Formação Alter do Chão, Bacia do Amazonas. Revista Brasileira de Geociências. 5 (2): 58.1975.

DAEMON, R. F.; CONTRERAS, C. J. A. Zoneamento palinológico da Bacia do Amazonas. In: Congresso Brasileiro de Geologia, 25, 1971, São Paulo. Anais... São Paulo: SBG, v. 3, p. 79-88, 1971.

DEMÉK, J. Manual of Detailed Geomorphological Mapping. Academia, Prague, 1972.

DESLOGES, J. R.; CHURCH, M. A. Wandering gravel-bed rivers. Canadian Geographer 33, 360-364, 1989.

DINO, R.; SILVA, O. B.; ABRAHÃO, D. Caracterização palinológica e estratigráfica de estratos cretáceos da Formação Alter do Chão, Bacia do Amazonas. In: Simpósio sobre o Cretáceo do Brasil, 5, 1999, Rio Claro. Boletim... Rio Claro: SBG, UNESP, p. 557-65, 1999.

DNPM - Departamento Nacional da Produção Mineral. Projeto RADAMBRASIL. Folha SA-20 Manaus; geologia, geomorfologia, pedologia, vegetação e uso potencial da terra. Rio de Janeiro, 628p, 1978.

DOUGLAS, I. Humid Landforms. Cambridge: MIT Press, 1977.

EIRAS, J. F.; BECKER, C. R.; SOUZA, E. M.; GONZAGA, F. G.; SILVA, J. G. F.; DANIEL, L. M. F.; MATSUDA, N. S.; FEIJÓ, F. J. Bacia do Solimões. Boletim de Geociências da Petrobrás, v. 8, n. 1, p. 17-45, 1994.

EMBRAPA. Centro Nacional de Pesquisa de Solos (Rio de Janeiro, RJ). Manual de métodos de análise de solo. Centro Nacional de Pesquisa de Solos. 2. ed. rev. atual. Rio de Janeiro, 1997.

ESPINOZA, J. C. V.; GUYOT, J. L.; RONCHAIL, J.; COCHONNEAU, G.; FILIZOLA, N.; FRAIZY, P.; LABAT, D.; OLIVEIRA, E.; ORDONEZ, J. J.; VAUCHEL, P. Contrasting regional discharge evolutions in the Amazon basin (1974-2004). Journal of Hydrology 375: 297-311, 2009.

ESPINOZA, J. C. V.; RONCHAIL, J.; GUYOT, J. L.; JUNQUAS, C.; DRAPEAU, G.; MARTINEZ, J. M.; SANTINI, W.; VAUCHEL, P.; LAVADO, W.; ORDONEZ, J.; ESPINOZA, R. From drought to flooding: understanding the abrupt 2010-11 hydrological 
annual cycle in the Amazonas River and the tributaries. Environmental Research Letters, 7, 7pp, 2012.

ESTAIANO, J. C. Impactos da mineração de areia em planícies fluviais meândricas na bacia do Alto Tietê (sob a perspectiva da antropogeomorfologia) - o caso da Mineração Ponte Alta. Dissertação de Mestrado. Departamento de Geografia. Faculdade de Filosofia Letras e Ciências Humanas - Universidade de São Paulo. 2007.

FEARNSIDE, P. M. Amazonia and global warming: Annual balance of greenhouse gas emissions from land-use change in Brazil's Amazon region. In: J. Levine (ed.) Biomass Burning and Global Change. Volume 2: Biomass Burning in South America, Southeast Asia and Temperate and Boreal Ecosystems and the Oil Fires of Kuwait. MIT Press, Cambridge, Massachusetts, E.U.A. 902 p, 1996.

FERREIRA, L. V. O uso de análise de lacunas e paisagens para a identificação de áreas prioritárias para a conservação da biodiversidade no bioma Amazônia. Anais, 54 Congresso Nacional de Botânica, Museu Paraense Emilio-Goeldi, p.143-144. 2003.

FILIZOLA, N. P. O fluxo de sedimentos em suspensão nos rios da Bacia Amazônica brasileira. Publ. ANEEL, Brasília. 63, 1999.

FILIZOLA, N.; GUYOT, J. L.; MOLINIER, M.; GUIMARÃES, V.; OLIVEIRA, E.; FREITAS, M. A. Caracterização hidrológica da Bacia Amazônica. In: RIVAS, A.; FREITAS, C. E de C. Amazônia uma perspectiva interdisciplinar. Manaus: EDUA, p. 33-53, 2002.

FILIZOLA, N.; GUYOT, J. L. Balanço do fluxo de sedimentos em suspensão da Bacia Amazônica. Projeto Manejo dos Recursos Naturais da Várzea - ProVárzea - IBAMA. Workshop - Geotecnologias aplicadas nas áreas de várzeas na Amazônia. Manaus-AM, 10p, 2007.

FILIZOLA, N.; SPÍNOLA, N.; ARRUDA, W.; SEYLER, F.; CALMANT, S.; SILVA, J. The Rio Negro and Rio Solimões confluence point - hydrometric observations during the 2006/2007 cycle. River, Coastal and Estaurine Morphodynamics: RECM 2009 - Vionnet et al. (eds) Taylor \& Francis Group, London, 2009.

FLEMMING, B.W. A revised textural classification of gravel-free muddy sediments on the basis ternary diagrams. Continental Shelf Research, n. 20, p. 1125-1137, 2000.

FOSBERG, F. R. Man's Role in the Island Ecosystem. Honolulu: Bishop Museum Press. 1963.

FRANCO, E. M. S.; MOREIRA, M. M. M. A. Geomorfologia da Folha SA.19 Içá. Rio de Janeiro: Projeto RADAMBRASIL. (Levantamento de Recursos Naturais), 14: 125-180, 1977.

FRANZINELLI, E.; IGREJA, H. L. S. Utilização de sensoriamento remoto na investigação na área do baixo Rio Negro e grande Manaus. In: VI Simpósio Brasileiro de Sensoriamento Remoto, 1990, Manaus. Anais. 1990. v. 3: 641-648, 1990. 
FRANZINELLI, E.; IGREJA, H. L. S. Modern sedimentation in the lower Negro River, Amazonas state, Brazil. Geomorphology, v. 44, p. 259-271, 2002.

FRANZINELLI, E.; LATRUBESSE, E. Rio Negro: Características gerais e da sedimentação quaternária. In: Anais... VIII Simpósio de Geologia da Amazônia. Manaus-AM. CD-ROM, 2003.

FRITSCH, E.; ALLARD, Th.; BENEDETTI, M. F.; BARDY, M.; NASCIMENTO, N. R.; LI, Y.; CALAS, G. Organic complexation and translocation of ferric iron in podzols of the Negro River watershed. Separation of secondary Fe species from Al species. Geochimica et

Cosmochimica Acta 73: 1813 - 1825, 2009.

GRAHN, Y. Ordovician chitinozoa and biostratigraphy of Brazil. Geobios, v. 6, n. 25, p. 70323, 1991.

GRAHN, Y. Revision of Silurian and Devoniam Strata of Brazil. Palinology, 16, p. 35-61, 1992.

GRAHN, Y.; PARIS, F. Age and correlation of the Trombetas Group, Amazonas Basin, Brazil. Rev. Micropaliontologie, v. 35, p. 197-209, 1992.

GREGORY, K. L. A Natureza da Geografia Física. Rio de Janeiro: Bertrand Brasil. 367p. 1992.

GUERRA, A. T.; GUERRA, A. J. T. Novo Dicionário Geológico-Geomorfológico. Rio de Janeiro: Bertrand Brasil, 2009.

GUPTA, A. E. The changing geomorphology of the humid tropics. Geomorphology, 7, 165186, 1993.

GUPTA, A. E. Large Rivers. Geomorphology and Management. John Wiley \& Sons Ltda. England. 2007.

GUPTA, A. E. Tropical Geomorphology. Cambridge University Press, 386p. 2011.

GUYOT, J. L.; MOLINIER, M.; GUIMARÃES, V.; CUDO, K. J.; OLIVEIRA, E. Balanço Hídrico da Bacia do Rio Negro. X Simpósio Brasileiro de Recursos Hídricos e I Simpósio de Recursos Hídricos do Cone Sul. Anais 2. Gramado-RS, 1993.

HACK, J. T. Interpretation of erosional topography in humid temperate regions. In: American Journal of Science, 258-A: 80-97. 1960.

HART, M.G. Geomorphology, pure and applied. London, George Allen e Unwin. 1986.

HAYAKAWA, E. H.; ZAN, H.; ANDRADES FILHO C. O.; BERTANI, T. C.; ROSSETTI, D. F. Identificação de paleocanais na bacia amazônica a partir de dados de sensoriamento remoto. Revista de Geografia. Recife: UFPE - DCG/NAPA, v. especial VIII SINAGEO, n.1, Set. 2010. 
IBGE -. Instituto Brasileiro de Geografia e Estatística. Manual Técnico de Pedologia. $2^{\mathrm{a}}$ edição. Manuais Técnicos em Geociências, n. 4. Rio de Janeiro: IBGE, 2007.

IBGE - Instituto Brasileiro de Geografia e Estatística. Mapa Exploratório de Solos do Estado do Amazonas. Disponível em:

fttp://geoftp.ibge.gov.br/mapas_tematicos/pedologia/unidades_federacao/am_pedologia.pdf, 2010 .

IBGE - Instituto Brasileiro de Geografia e Estatística. Mapa Geomorfológico do Estado do Amazonas. Disponível em:

fttp://geoftp.ibge.gov.br/mapas_tematicos/geomorfologia/unidades_federacao/am_geomorfol ogia.pdf, 2010.

INMET - Instituto Brasileiro de Meteorologia. Banco de Dados Meteorológicos para Ensino e Pesquisa. Disponível em:

http://www.inmet.gov.br/portal/index.php?r=bdmep/bdmep. Acesso em 2012.

IRION, G.; ADIS, J. Evolução de florestas amazônicas inundadas, de igapó - um exemplo do rio Tarumã-mirim. Acta Amazonica. 9 (2): 299-303, 1979.

IRION, G.; JUNK, W.J.; MELLO, J. A. N. The large Central Amazonian River floodplains near Manaus: geological, climatological, hydrological, and geomorphological aspects. In: Junk, W.J.(ed). The Central Amazon Floodplain. Ecological Studies, 126, 1997.

JOHNSON, A. M. The climate of Peru, Bolivia and Ecuador. In: SCHWERDTFEGER,W. (ed.). Climates of Central and South America. World Survey of Climatology. Vol. 12, 147218. Elsevier. 1976.

JUNK, W. J. Áreas inundáveis - Um desafio para limnologia. Acta Amazonica. 10 (4): 775795, 1980.

JUNK, W. J. As águas da Região Amazônica. In: SALATI, E.; JUNK, W. J.; SHUBART, H. O. R.; OLIVEIRA, A. E. Amazônia: desenvolvimento, integração e ecologia. São Paulo: Brasiliense: Conselho de Desenvolvimento Científico e Tecnológico. 1983.

JUNK, W. J. Flood tolerance and tree distribution in Central Amazonian floodplains. In: Tropical forests: Botanical dynamics, speciation and diversity. Eds. L.B. NIELSEN; I.C. NIELSEN; H. BALSLEV. Academic Press London. pp. 47-64, 1989.

JUNK, W. J. Wetlands of tropical South America. In: Wetlands in the Amazon floodplain. Hydrobiology. 263, p. 155-162, 1993.

JUNK, W. J.; BAYLEY, P. B.; SPARKS, R. E. The flood pulse concept in river floodplain systems. In: DODGE D.P. (ed.) Proceedings of the International Large River Symposium. Can. Publ. Fish. Aquat. Sci. 106:110-127. 1989.

JUNK, W. J.; PIEDADE, M. T. F. Plant life in the floodplain with special reference to herbaceous plants. In: The central Amazon floodplain (W.J. Junk, ed.). Springer-Verlag, Berlin, p.147-186, 1997. 
KISTLER, P. Historical resume of the Amazon Basin. PETROBRAS/RENOR, Belém, Rel. Interno (inédito). 1954.

KLIR, G. J. Teorica polifônica general de sistemas. Tendencias em La Teoría general de sistemas. $3^{\text {a }}$ Ed. Madrid: Alianza Universidad. Versão Espanhola de Alvaro Delgado e André Ortega. p. 9-27, 1987.

KNIGHTON, A.D. Fluvial Forms and Processes: A New Perspective. Nova York, John Wiley \& Sons. 1998.

LANGE, F. W. Subdivisão bioestratigráfica e revisão da coluna siluro-devoniana da Bacia do baixo Amazonas. Atas do Simpósio sobre a Biota Amazônica (Geociências), 1: 215-326, 1967.

LATRUBESSE, E. M. Patterns of anabranching channels: The ultimate end-member adjustment of mega rives. Geomorphology. 101, 130-145, 2008.

LATRUBESSE, E., FRANZINELLI, E. The late Quaternary evolution of the Negro river, Amazon Brazil: implications for islands and floodplains formation in large anabranching tropical systems. Geomorphology. 70, 372-397, 2005.

LATRUBESSE, E. M.; STEVAUX, J. C.; SINHA, R. Grandes sistemas fluviais tropicais: uma visão geral. Revista Brasileira de Geomorfologia. Ano 6, n.1, p. 01-18, 2005.

LEENHEER, J.A. Origin and nature of humic substances in the Waters of the Amazon River basin. Acta Amazonica. 10: 513 - 526, 1980.

LEENHEER, J. A.; SANTOS, H. Considerações sobre os processos de sedimentação na água preta ácida do rio Negro (Amazônia Central). Acta Amazônica. 10 (2): p.343-355. 1980.

LEOPOLD, L. B.; WOLMAN, M. G. River channel patterns; braided, meandering, and straight. US Geological Survery professional paper, 282-B, 1957.

LEOPOLD, L. B; WOLMAN, M. G.; MILLER, J. P. Fluvial Processes in Geomorphology. San Francisco: W.H. Freeman and Company, 522p. 1964.

LUZ, R. A. Geomorfologia da Planície Fluvial do Rio Pinheiros entre os bairros de Pinheiros, Butantã e Cidade Jardim, São Paulo (SP). Dissertação de Mestrado. Departamento de Geografia. FFLCH/USP. São Paulo. 2010.

MAIA, R. G. N.; GODOY, H. O.; YAMAGUTI, H. S.; MOURA, P. A.; COSTA, F. S. F.; HOLANDA, M. A.; COSTA, J. A. Projeto carvão no alto Solimões. Relatório Final, Manaus, CPRM/DNPM, v.1, 142p, 1977.

MEADE, R. H.; NORDIN JR., C. F.; CURTIS, W. F.; MAHONEY, H. A.; DELANEY, B. M. Suspended-sediment and velocity data, Amazon River and its tributaries, June-July 1976 and May-June 1977. U.S. Geological Survey Open-File Report 79-515, 42p. 1979.

MEADE, R. H.; RAYOL, J. M.; CONCEIÇÃO, S. C.; NATIVIDADE, J. R. G. Backwater effects in the Amazon River Basin of Brazil. Environ. Geol. Sci. 18(2), p. 105-114, 1991. 
MERTES, L. A.; DUNNE, T. Effects of tectonism, climate change and sea-level change on the form and behavior of the modern Amazon River and its floodplain. In: GUPTA, A. (ed) Larger Rivers: Geomorphology and management. Chichester: Wiley, 114-144. 2007

MIALL, A. D. The Geology of Fluvial Deposits: Sedimentary Facies, Basin Analysis, and Petroleum Geology. New York: Springer-Verlag Berlin Heidelberg, 582p, 1996.

MOLINIER, M.; GUYOT, J. L.; OLIVEIRA, E.; GUIMARÃES, V.; CHAVES, A. Hidrologia da Bacia do Rio Amazonas. A Água em Revista. p. 31-36, 1994.

MOLINIER, M.; GUYOT, J. L.; OLIVEIRA, E.; GUIMARÃES, V. Les regimes hydrologiques de l'Amazone et de sés affluentes. In: L'hydrologie Tropicale: Géoscience et outil pour Le Développement, Paris: IAHS Pub. 238, p. 209-222, 1996.

MOREIRA, D. M. Rede de Referência Altimétrica para Avaliação da Altimetria por Satélites e Estudos Hidrológicos na Região Amazônica. Dissertação de Mestrado. Rio de Janeiro: UFRJ/COPPE, 2010.

NANSON, G.C.; KNIGHTON, A.D. Anabranching rivers: their causes, character and classification. Earth Surface Processes and Landforms 21 (3): 217-239. 1996.

NASCIMENTO, D. A.; MAURO, C. A.; GRACIA, M. G. L. Geomorfologia. In: BRASIL Departamento Nacional da Produção Mineral. Projeto RADAMBRASIL. Folha SA-21 Santarém. Levantamento de Recursos Naturais, v. 10, 522p, Rio de Janeiro, 1976.

NASCIMENTO, N. R.; BUENO, G. T.; FRITSCH, E.; HERBILLON, A. J.; ALLARD, TH.; MELFI, A.J.; ASTOLFO, R.; BOUCHER, H.; LI, Y. Podzolization as a desferralitization process: a study of an Acrisol-Podzol sequence derived from Palaeozoic sandstones in the northern upper Amazon Basin. European Journal of Soil Science. 55, p. 523-528, 2004.

NASCIMENTO, N. R.; FRITSCH, E.; BUENO, G.T.; BARDY, M.; GRIMALDI, C.; MELFI, A.J. Podzolization as a deferralitization process: dynamics and chemistry of ground and surface waters in an Acrisol - Podzol sequence of the upper Amazon Basin. European Journal of Soil Science. 59, p. 911-924, 2008.

NEVES, C. A. O. Prospectos potenciais e áreas prioritárias para exploração na Bacia do Amazonas. In: Boletim de Geociências da Petrobrás. v. 4, n01, p. 95-103, 1990.

NOGUEIRA, A. C. R.; SILVA JUNIOR, J. B. C.; HORBE, A. M. C.; SOARES, J. L.; MONTEIRO, A.D. A Gênese dos níveis silicificados da Formação Alter do Chão, Cretáceo Superior da Bacia do Amazonas. In: Simpósio de Geologia da Amazônia, VIII, 2003, Manaus. Anais... Manaus: SBG/NO, 2003. CD-ROM.

NUNES DE MELLO, J.A.; BARROS, W. G. Enchentes e vazantes do rio Negro medidas no porto de Manaus, Amazonas, Brasil. Acta Amazonica. 31(2): 331-337, 2001.

OLIVEIRA, A. A. B.; PITTHAN, J. H. L.; GARCIA, M. G. L. Geomorfologia da Folha SB.19 Juruá. Rio de Janeiro: Projeto RADAMBRASIL (Levantamento de Recursos Naturais), 15: 91-142, 1977. 
OLIVEIRA, M. A. T.; LIMA, G. L. Classificação de sedimentos quaternários em cabeceiras de vale através da aplicação do Diagrama de Flemming: Município de Campo Alegre, norte de Santa Catarina. São Paulo, UNESP, Geociências. v. 23, nº 1/2, p.67-78, 2004.

OLSON, D.; DINERSTEIN, E.; CANEVARI, P.; DAVIDSON, I.; CASTRO, G.; MORISSET, V.; ABELL, R.; TOLEDO, E. (eds.). Freshwater Biodiversity of Latin America and the Caribbean: A conservation assessment. Biodiversity Support Program, Washington, D.C. 61p, 1998.

PAIVA, G. Valle do rio Negro: physiografia e geologia. Boletim do Serviço Geológico e Mineralógico. Rio de Janeiro (40): 1-62. 1929

PAROLIN, P.; ADIS, J.; RODRIGUEZ, W.; AMARAL, I.; PIEDADE, M. T. F. Floristic study of an igapó floodplain forest in Central Amazonia (Tarumã-Mirim, Rio Negro).

Amazoniana. 18(1/2): 29-47, 2004.

PAROLIN, P.; PIEDADE, M. T. F.; JUNK, W. J. Os rios da Amazônia e suas interações com a floresta. Ciência e Ambiente. Universidade Federal de Santa Maria. UFSM, v.?, n.31, 2005.

PEJRUP, M., The triangular diagram used for classification of estuarine sediments: a new approach. In: de Boer, P.L., van Gelder, A., Nio, S.D. (Eds.), Tide-Influenced Sedimentary Environments and Facies. Reidel, Dordrecht, pp. 289-300, 1988.

PEREIRA E. R. Possibilidades metalogenéticas na região do Domo de Monte Alegre - PA. In: SBG, Cong. Bras. Geol., 35, Belém, Anais, v.1, p.286-295, 1988.

PIEDADE, M. T. F.; JUNK, W. J.; ADIS, J.; PAROLIN, P. Ecologia, zonação e colonização da vegetação arbórea das Ilhas Anavilhanas. Pesquisa Botânica. n 58. 117-144 São Leopoldo: Instituto Anchietano de Pesquisas. 2005.

PIRES, J. M. Tipos de Vegetação da Amazônia. Brasil Florestal. 5(17): 48-58. 1974.

PIRES, J. M.; PRANCE, G. T. The vegetation types of the Brazilian Amazon. p. 109-145. In: PRANCE, G. T.; LOVEJOY, T. E. (eds.). Key Environments: Amazonia. Pergamon Press, Oxford. 1985.

POTTER, P. E. Significance and origin of big rivers. Journal Geology. 86, 13-33, 1978.

PRANCE, G. T. A terminologia dos tipos de florestas Amazônicas sujeitos à inundação. Acta Amazonica. 10, p.495-504, 1980.

PRINCE, L. I. Dentes de Theropoda num testemunho de sondagem no Estado do Amazonas. Rio de Janeiro, An. Acad. Bras. Ci., 32 (1): 79-84. 1960.

QUADROS, L. P.; MELO, J. H. G.; GRAN, Y. Carta bioestratigráfica da Bacia do Amazonas. In: BEURLEIN, G.; QUADROS, L. P. (Eds) Bioestratigrafia das bacias paleozoicas brasileiras. Texto explicativo das cartas bioestratigráficas, versão 01.90. Rio de Janeiro, PETROBRÁS. Relatório Interno. 1990. 
REYNOLDS, R. Tropical meteorology. Progress in Physical Geography. 9, 157-186, 1985.

ROCHE, M. A., FERNANDEZ, C., ALIAGA, A., PEÑA, J.; SALAS, E., MONTAÑO, J. L. Balance hídrico de Bolivia. Publ. UNESCO PHICAB, La Paz, 16 p. 1992.

RODRIGUES, C. Geomorfologia Aplicada: Avaliação de experiências e de instrumentos de planejamento físico-territorial e ambiental brasileiros. São Paulo DG/FFLCH-USP, Tese de Doutoramento. 1997.

RODRIGUES, C. A teoria geossistêmica e sua contribuição aos estudos geográficos e ambientais. In: Revista do Departamento de Geografia. 14 p. 69-77, 2001.

RODRIGUES, W. A. Estudo preliminar de mata de várzea alta de uma ilha do baixo Rio Negro de solo argiloso e úmido. Publicação do INPA - Série Botânica, 10: 50, 1961.

SAKAMOTO, T. Trabalhos sedimentológicos, geomorfológicos e pedogenéticos referentes à Amazônia. Belém, SPVEA, 179p, 1957.

SALATI, E.; MARQUES, J. Climatology of the Amazon region, In: SIOLI H. The Amazon Limnology and landscape ecology of a mighty tropical river and its basin. Dordrecht: Junk Publ., p. 85-126, 1984.

SANTANA, C. L. Geomorfologia da planície fluvial do Rio Ribeira de Iguape entre Sete Barras e Eldorado (SP): Subsídios ao planejamento físico-territorial de áreas inundáveis. Dissertação Mestrado. Departamento de Geografia. Faculdade de Filosofia Letras e Ciências Humanas - Universidade de São Paulo. 2007.

SANTOS, J. O. S et al. Projeto Norte da Amazônia, domínio baixo rio Negro. Relatório Final. DNPM/CPRM, Manaus, 5v. in 8 (Relatório do arquivo técnico da DGM, 2186). v. 5, 1974.

SELBY, M. J. Hillslope Materials and Processes. Oxford University Press. 1993.

SCHUMM, S. A. The Fluvial System. Wiley, New York, 1977.

SCHUMM, S. A. Patterns of alluvial rivers. In: Annual Review of Earth and Planetary Sciences, 13: 5-27. 1985.

SCHUMM, S. A. Evolution and response of the fluvial system, sedimentologic implications. SEPM Spec. Publ. 31 pp. 19-29. 1981.

SCHMIDT, G. W. Amounts of suspended and dissolved substances in the middle reaches of the Amazon over the course of one year. Amazoniana. 3 (2): 208 -223, 1972.

SMITH, D.G.; SMITH, N.D. Sedimentation in anastomosed river systems: examples from alluvial valleys near Banff, Alberta. Journal of Sedimentary Petrology. 50 (1):157-164. 1980. 
SILVA, C. L. Análise da tectônica cenozóica na região de Manaus e adjacências. Rio Claro. Tese de doutorado em geologia regional, defendida no Instituto de Geociências e Ciências Exatas da Universidade Estadual Paulista (UNESP). 2005.

SILVA C. L.; MORALES, N.; CRÓSTA, A. P.; COSTA, S. S.; JIMENEZ-RUEDA, J. R. Analysis of tectonic-controlled fluvial morphology and sedimentary processes of the western Amazon basin: an approach using satellite images and digital elevation model. Anais da Academia Brasileira de Ciências. Vol.79, n.4, p.693-711. 2007.

SILVA, C. L.; ROSSETTI, D. F.. História geológica dos rios da Amazônia. Ciência e Cultura. [online], vol.61, n.3, p. 24-26. 2009.

SILVA, J. P. Avaliação da diversidade de padrões de canais fluviais e da geodiversidade na Amazônia - Aplicação e Discussão na Bacia Hidrográfica do Rio Xingu. Teses de Doutorado. Departamento de Geografia. FFLCH/USP. 277p. 2012.

SIOLI, H. Amazônia: fundamentos de ecologia da maior região de florestas tropicais. Petrópolis: Vozes, 1991.

SIOLI, H. The Amazon Limnology and Landscape Ecology of a Mighty Tropical River and its Basins. Dr. Junk Publisher, Dordrecht, The Netherlands. 1984.

SOARES, L. C. Hidrografia. In: Fundação Instituto Brasileiro de Geografia e Estatística (IBGE). Geografia do Brasil, Região Norte. Rio de Janeiro, RJ. 1977.

SOUZA, M. de M. Perfil geológico da BR-174 (Manaus- Boa Vista) no trecho Manaus-Serra do Abonari. In: $28^{\circ}$ Congresso Brasileiro de Geologia. Porto Alegre. Anais... SBG. v. 2, p. 75-86. 1974.

SOTCHAVA, V. B. O estudo de geossistemas. São Paulo, Instituto de Geografia USP. 51p. Métodos em Questão, 16. 1977.

SOTCHAVA, V. B. Por uma teoria de classificação de geossistemas de vida terrestre. São Paulo, Instituto de Geografia USP, 23p. Biogeografia, 14. São Paulo, 1978.

SUGUIO, K. Rochas Sedimentares: propriedades, Gênese, Importância Econômica. São Paulo: Edgard Blucher, 1980.

SUGUIO, K. Geologia Sedimentar. São Paulo: Editora Blucher, 2003.

SUGUIO, K.; BIGARELLA, J. J. Ambientes Fluviais. Florianópolis: Ed. da UFSC. $2^{\text {a }}$ Ed. revista, 183p, 1990.

STERNBERG, H. O. Vales tectônicos na planície Amazônica? Revista Brasileira de Geografia. v. 12: 513-533. 1950

TASSINARI, C. C. G.; BETTENCOURT, J. S.; GERALDES, M. C.; MACAMBIRA, M. J. B.; LAFON, J. M. The Amazonian Craton. In: CORDANI, U. G., MILANI, E. J., THOMAZ FILHO, A., CAMPOS, D. A. eds. Tectonic evolution of South America: Rio de Janeiro: 31st. International Geological Congress, p. 41-95, 2000. 
TRAVASSOS, W. A.; BARBOSA FILHO, C. M. Tectonismo terciário na área do Rio Tapajós, Bacia do Amazonas. Boletim de Geociências da Petrobrás. v. 4, n. 3, p. 299-314, 1990.

TRICART, J. Tendências atuais da Geomorfologia. In: Visitas de Mestres Franceses. CNG, IBGE, Rio de Janeiro, 1963.

TRICART, J. Príncipes et méthodes de La Géomorphologie. Masson et Cie, Paris, 1965.

TRICART, J. Tipos de Planícies Aluviais e de Leitos Fluviais na Amazônia Brasileira.

Revista Brasileira de Geografia. IBGE. Rio de Janeiro. 39 (2): 3-40. 1977.

TRICART, J. Ecodinâmica. Rio de Janeiro: IBGE/SUPREN. 91p, 1977.

VALE, C.C. Séries Geomorfológicas Costeiras do Estado do Espírito Santo e os habitats para o desenvolvimento dos manguezais: uma visão sistêmica. Tese de Doutoramento. Departamento de Geografia. FFLCH/USP. São Paulo. 2004.

VELOSO, H. P.; RANGEL-FILHO, A. L. R.; LIMA, J. C. A. Classificação da vegetação brasileira adaptada a um sistema universal. Rio de Janeiro: IBGE, 124p. 1991.

VIEIRA L. C.; NOGUEIRA A. C. R. Petrografia de arenitos da Formação Alter do Chão, Cretáceo-Terciário da Bacia do Amazonas, Praia da Ponta Negra, Manaus. In: Simp. de Inic. Científica da USP, 3, São Carlos. Anais, São Paulo, USP, p.165. 1998.

WANDERLEY FILHO. J. R. Evolução estrutural da Bacia do Amazonas e sua relação com o embasamento. Master's Thesis, Centro de Geociências, Universidade Federal do Pará, Belém, p.125, 1991.

WENTWORTH, C.K., A scale of grade and class terms for clastic sediments. Journal of Geology 30, 377-392, 1922.

WITTMANN, F.; JUNK, W. J.; PIEDADE, M. T. F. The varzea forests in Amazonia: Flooding and the highly dynamic geomorphology interact with natural forest succession. Forest Ecol. Managem. 196:199-212, 2004. 